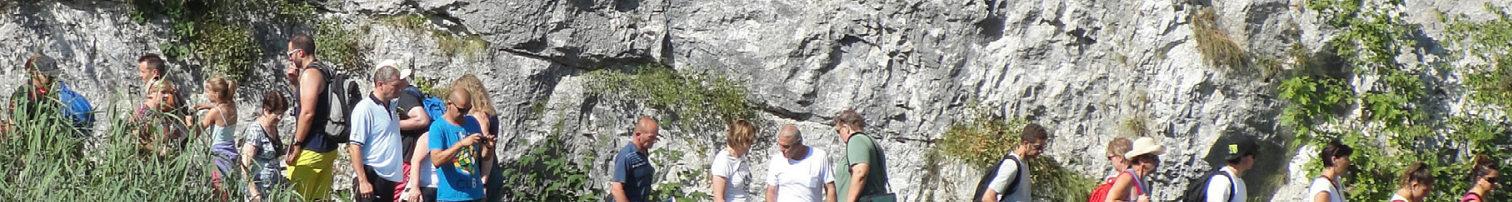
1.7.

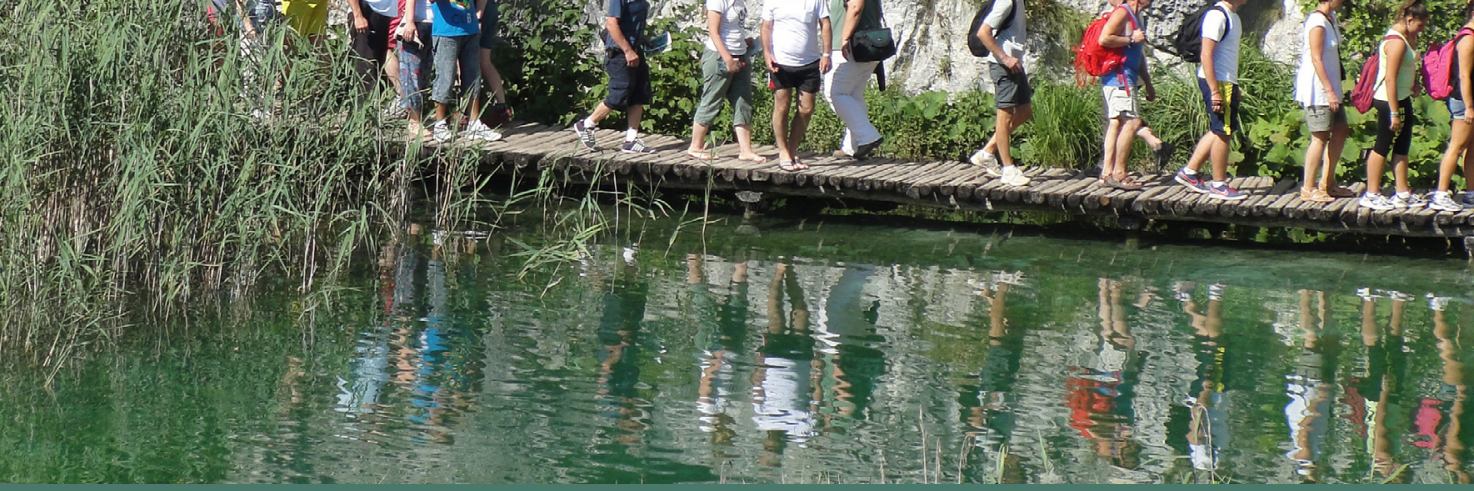

\title{
CHALLENGES OF TOURISM DEVELOPMENT IN PROTECTED AREAS OF CROATIA AND SLOVENIA
}

Edited by Miha Koderman and Vuk Tvrtko Opačić

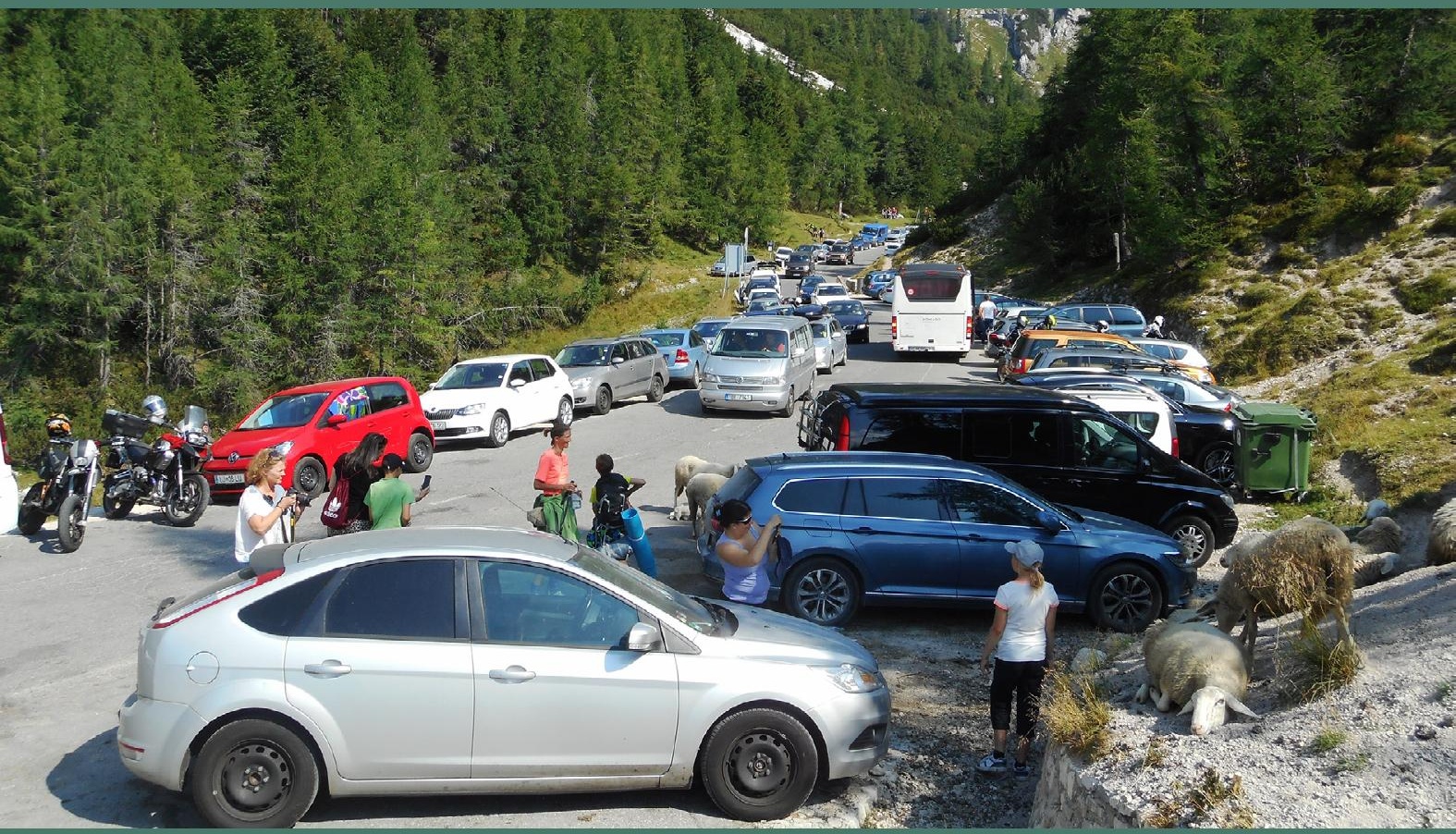



challenges of tourism development in protected areas of croatia and slovenia 



\section{Challenges of tourism development in protected areas of Croatia and Slovenia}

Edited by Miha Koderman and Vuk Tvrtko Opačić

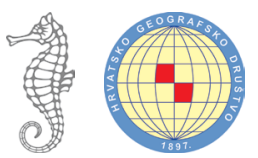


Scientific Monograph

Challenges of tourism development in protected areas of Croatia and Slovenia

Editors " Miha Koderman, Vuk Tvrtko Opačić

Reviewers - Dejan Cigale, Zoran Klarić

Language Editor - Christopher Grey Kaufmann

Typesetting " Jonatan Vinkler

Cover photos - Izidora Marković Vukadin (Plitvice Lakes National Park),

Miha Koderman (Triglav National Park)

Published by

Založba Univerze na Primorskem (for publisher: Prof. Klavdija Kutnar, PhD, Rector)

Titov trg 4, SI-6ooo Koper

Editor-in-chief - Jonatan Vinkler

Managing editor " Alen Ježovnik

Hrvatsko geografsko društvo/Croatian Geographical Society (for publisher: Prof. Danijel Orešić, PhD, President) Marulićev trg 19, HR-1000o Zagreb

Koper, Zagreb 2020

ISBN 978-961-7055-08-5 (pdf)

http://www.hippocampus.si/ISBN/978-961-7055-08-5.pdf

ISBN 978-961-7055-09-2 (html)

http://www.hippocampus.si/ISBN/978-961-7055-09-2/index.html

DOI: https://doi.org/10.26493/978-961-7055-08-5

(C) 2020 Založba Univerze na Primorskem/University of Primorska Press

and Hrvatsko geografsko društvo/Croatian Geographical Society

Izdaja je sofinancirana po pogodbi ARRS za sofinanciranje izdajanja znanstvenih monografij v letu 2020.

Publication of this book is financially supported by Ministry of Science and Education of the Republic of Croatia for the year 2020 .

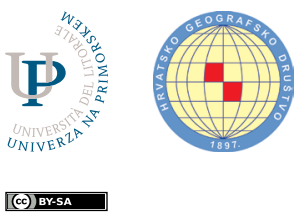

Kataložni zapis o publikaciji (CIP) pripravili v Narodni in univerzitetni knjižnici v Ljubljani

COBISS.SI-ID $=33308163$

ISBN 978-961-7055-08-5 (pdf)

ISBN 978-961-7055-09-2 (html) 


\section{Contents}

7 Preface

Vuk Tvrtko Opačić, Miha Koderman

9 Chapter 1: Explanatory notes on tourism in protected areas of Croatia and Slovenia

Slaven Gašparović, Vuk Tvrtko Opačić

27 Chapter 2: Transport accessibility as a factor of tourist flow in Croatian national parks and nature parks

Petra Radeljak Kaufmann

53 Chapter 3: Rural tourism in the surroundings of Krka National Park: factors of development and spatial impacts

Ivan Šulc

75 Chapter 4: Tourism in protected areas and the transformation of Mljet island, Croatia

Valentina Brečko Grubar, Nataša Kolega, Gregor Kovačič

103 Chapter 5: The importance of protected areas on the Slovenian coast for tourism and how they could be impacted by climate change

Romina Rodela, Valentina Brečko Grubar

121 Chapter 6: Nature-based tourism in the eastern part of Kraški Rob: an overview of current situation and future prospects

Gregor Kovačič, Miha Koderman

145 Chapter 7: Development of tourism and second homes in the area of Sviščaki in southwestern Slovenia 
Bojana Lipej, Lovrenc Lipej, Simon Kerma

173 Chapter 8: Škocjanski zatok Nature Reserve: a case study of a protected urban wetland area and tourist attraction

Igor Jurinčič

193 Chapter 9: Spatial planning of tourism in protected nature areas in Slovenia and the tourism carrying capacity of Škocjan Caves Regional Park

Izidora Marković Vukadin

211 Chapter 10: The interrelation between development, management, and management issues in Plitvice Lakes National Park

Miha Koderman, Vuk Tvrtko Opačić, Izidora Marković Vukadin

241 Chapter 11: Tourism development and green horizons in protected areas of Croatia and Slovenia: synthesis and perspectives

253 Authors

259 Reviews 


\section{Preface}

This collection of research is the result of fruitful collaboration between the Department of Geography of the University of Zagreb in Croatia, and the Department of Geography of the University of Primorska in Slovenia, which was implemented within the framework of a bilateral research project entitled "Comparative analysis of spatial development of tourism in protected areas of Croatia and Slovenia", in 2018 and 2019.

The authors found a background for their research in the fact that Croatia and Slovenia are interesting cases for examining the spatial development of tourism in protected areas of nature, as they shared the same socio-economic context of development in the former Socialist Federal Republic of Yugoslavia. After their independence and the period of transition, they faced different development dynamics and adopted various approaches for management and development of protected areas. Today, both countries are members of the European Union and are confronted with many similar challenges regarding the implementation of the concept of sustainable tourism in protected areas.

The main objective was to perform a comparative analysis of the spatial development of tourism in protected areas in Croatia and Slovenia. In order to achieve this goal, the authors of the chapters studied several examples of tourism development in protected areas in both countries. Spatial development of tourism was analysed using quantitative and qualitative methods (e.g. in-depth interviews with relevant stakeholders) with an ap- 
propriate cartographic depiction in GIS and graphic presentation of data. Additionally, special emphasis was given to the question of spatial planning and management with elaboration of proposals and recommendations for the further development of tourism in the protected areas of both countries.

Chapters in this monograph were concluded in December 2019 and consequently they do not mention the COVID-19 pandemic that has shaken the world and established a "new reality" in the tourism sector. The editors are satisfied that the extent of the studied protected area will expand in the near future with the establishment of Dinara Nature Park in Croatia. These facts confirm the importance of continuous research of tourism in general, as well as tourism in protected areas, due to its rapidly changing character.

The authors of each chapter sincerely hope that this collection of work will contribute to scientific collaboration between geographers in Croatia and Slovenia, as well as with other scholars, practitioners, students and stakeholders who deal with management and sustainable development of tourism in protected areas.

The editors would like to thank the authors of the chapters for their commitment and collaboration, reviewers for their valuable input and critiques, as well as everyone else who was involved in the creation of this research and the publishing process. Special appreciation must be given also to our patient spouses for their enormous tolerance during couch surfing in Zagreb and Šenčur. 


\title{
Chapter I \\ Explanatory notes on tourism in protected areas of Croatia and Slovenia
}

\author{
Vuk Tvrtko Opačić, Miha Koderman
}

\section{Abstract}

In this chapter, IUCN categories of protected areas are defined, along with categories of protected areas in Croatia and Slovenia with emphasis on the harmonisation thereof with IUCN categories. Additionally, the intent of each individual category of protected area in Croatian and Slovenian legislation is explained, in order to assess the possibility of their tourism valorisation and make a comparison. Tourism develops and influences space in different ways throughout the world. This means that in the most visited protected areas, tourism has become one of the key factors for transformation of protected areas and their surroundings. In contrast, tourism is not strongly developed in less-popular protected areas, and their scientific, educational, and recreational functions are stronger than tourism.

Key words: categories of protected areas, IUCN, tourism, Croatia, Slovenia

\section{Introduction}

Increasing demand for tourism and recreational activities in protected areas has many positive and also negative environmental consequences. Managers of protected areas face important dilemmas when they decide 
between policies that strengthen nature conservation and consequently limit the progress of tourism related activities, and those that allow more moderate development of protected areas, thus enabling the growth of their recreational function. In the last decade, integrated management of protected areas has striven towards the implementation of the concept of sustainable tourism development. Although this concept has become widely accepted and has been successfully introduced in some protected areas, it is still often inappropriately and/or inadequately carried out in regard to its theoretical assumptions. Additionally, there is a frequent lack of concrete research aimed at identifying the spatial effects of tourism on the basis of defined and measurable indicators of the state of the environment.

The International Union for Conservation of Nature and Natural Resources (IUCN in further text) defines a protected area as 'a clearly defined geographical space, recognised, dedicated, and managed, through legal or other effective means, to achieve the long-term conservation of nature with associated ecosystem services and cultural values' (Leung et al., 2018). IUCN's definition of protected areas is partially included in both Croatian and Slovenian legislation that relates to nature protection (Berginc et al., 2006; Marković, 2015). According to Croatian Nature Protection Act (Official Gazette, 8o/13) a protected area is defined as a 'geographically clearly-defined area that is intended for nature protection and in which long-term actions for nature protection and ecosystem preservation are carried out'. In Slovenian legislation, nature protection is covered by the Nature Conservation Act (1999), the fundamental legal act that has been amended many times since its inception.

Protected areas are established in order to protect species and habitats, together with ecosystem services and natural processes (Sovinc, 2017) and can be classified into several categories concerning the level of conservation or management goals (Tab. 1).

It is important to mention that each state determines categories according to its own criteria, so the categories from different states that bear the same name might not actually be analogous in terms of level and manner of protection (Klarić and Gatti, 2006). In order to unify the criteria for declaring certain categories of protected areas on the global level, the tendency in most states is to implement the IUCN categorisation of protected areas (Dudley, 2008; Leung et al., 2018). Examples of harmonisation of categories of protected areas, as well as deviation from IUCN categorisation, are visible in some cases in Croatia and Slovenia. 
Tab. I IUCN protected area categories

\begin{tabular}{|c|c|c|}
\hline $\begin{array}{l}\text { IUCN } \\
\text { type }\end{array}$ & $\begin{array}{c}\text { Name } \\
\text { of the category }\end{array}$ & Definition \\
\hline Ia & Strict nature reserve & $\begin{array}{l}\text { Strictly protected for biodiversity and also possibly geological/ } \\
\text { geomorphological features, where human visitation, use and im- } \\
\text { pacts are controlled and limited to ensure protection of the con- } \\
\text { servation values. These areas are primary used for scientific re- } \\
\text { search and monitoring. }\end{array}$ \\
\hline $\mathrm{Ib}$ & Wilderness area & $\begin{array}{l}\text { Usually large unmodified or slightly modified areas, retaining } \\
\text { their natural character and influence, without permanent or sig- } \\
\text { nificant human habitation, protected and managed to preserve } \\
\text { their natural condition. }\end{array}$ \\
\hline II & National park & $\begin{array}{l}\text { Large natural or near-natural areas protecting large-scale eco- } \\
\text { logical processes with characteristic species and ecosystems, } \\
\text { which also have environmentally and culturally compatible } \\
\text { spiritual, scientific, educational, recreational and visitor oppor- } \\
\text { tunities. }\end{array}$ \\
\hline III & $\begin{array}{l}\text { Natural monument } \\
\text { or feature }\end{array}$ & $\begin{array}{l}\text { Areas set aside to protect a specific natural monument, which } \\
\text { can be a landform, sea mount, marine cavern, geological feature } \\
\text { such as a cave, or a living feature such as an ancient grove. This } \\
\text { category usually comprises of smaller areas with important sig- } \\
\text { nificance for visitors. }\end{array}$ \\
\hline IV & $\begin{array}{l}\text { Habitat/species man- } \\
\text { agement area }\end{array}$ & $\begin{array}{l}\text { Areas to protect particular species or habitats, where manage- } \\
\text { ment reflects this priority. Many will need regular, active inter- } \\
\text { ventions to meet the needs of particular species or habitats, but } \\
\text { this is not a requirement of the category. }\end{array}$ \\
\hline $\mathrm{V}$ & $\begin{array}{l}\text { Protected landscape } \\
\text { or seascape }\end{array}$ & $\begin{array}{l}\text { Where the interaction of people and nature over time has pro- } \\
\text { duced a distinct character with significant ecological, biological, } \\
\text { cultural and scenic value: and where safeguarding the integrity } \\
\text { of this interaction is vital to protecting and sustaining the area } \\
\text { and its associated nature conservation and other values. }\end{array}$ \\
\hline VI & $\begin{array}{l}\text { Protected areas with } \\
\text { sustainable use of } \\
\text { natural resources }\end{array}$ & $\begin{array}{l}\text { Areas which conserve ecosystems, together with associated cul- } \\
\text { tural values and traditional natural resource management sys- } \\
\text { tems. Generally large, mainly in a natural condition, with a pro- } \\
\text { portion under sustainable natural resource management and } \\
\text { where low-level non-industrial natural resource use, compatible } \\
\text { with nature conservation, is seen as one of the main aims. }\end{array}$ \\
\hline
\end{tabular}

Source: according to Leung et al., 2018, adapted by authors

\section{Categories of protected areas in Croatia and Slovenia}

According to data of the Ministry of Environment and Energy of the Republic of Croatia (2019c), protected areas encompass $8.54 \%$ of the total area of the Republic of Croatia, i.e. $12.22 \%$ of land territory and $1.94 \%$ of sea territory. Of all categories of protected areas in Croatia, the greatest amount of area is given to nature parks, ahead of significant landscapes, re- 


\section{gional, and national parks. Categories of protected areas in Croatia are di- vided by legislation according to the IUCN categorisations, as shown in Tab. 2, while their spatial distribution is shown in Fig. 1.}

Tab. 2 Types of protected areas in Croatia

\begin{tabular}{|c|c|c|c|c|c|}
\hline $\begin{array}{c}\text { Category } \\
\text { of protection }\end{array}$ & Purpose & $\begin{array}{l}\text { Manage- } \\
\text { ment level }\end{array}$ & $\begin{array}{c}\text { IUCN } \\
\text { category }\end{array}$ & $\begin{array}{c}\text { Number } \\
\text { of areas }\end{array}$ & $\begin{array}{c}\text { Surface } \\
\left(\mathrm{km}^{2}\right)\end{array}$ \\
\hline $\begin{array}{l}\text { Strict } \\
\text { reserve }\end{array}$ & $\begin{array}{l}\text { Conservation of original } \\
\text { nature, nature monitoring, } \\
\text { and education. }\end{array}$ & $\begin{array}{l}\text { National } \\
\text { and } \\
\text { regional }\end{array}$ & Ia & 2 & 24.19 \\
\hline $\begin{array}{l}\text { National } \\
\text { park }\end{array}$ & $\begin{array}{l}\text { Conservation of original natural } \\
\text { values; scientific, cultural, educa- } \\
\text { tional, tourism, and recreation- } \\
\text { al purpose. }\end{array}$ & National & II & 8 & 979.63 \\
\hline $\begin{array}{l}\text { Special } \\
\text { reserve }\end{array}$ & $\begin{array}{l}\text { Conservation of natural phe- } \\
\text { nomena due to uniqueness, rar- } \\
\text { ity, representativeness, and/or } \\
\text { particular scientific significance. }\end{array}$ & $\begin{array}{l}\text { National, } \\
\text { regional, } \\
\text { local }\end{array}$ & IV & 77 & 400.11 \\
\hline Nature park & $\begin{array}{l}\text { Protection of biological and } \\
\text { landscape diversity; educational, } \\
\text { cultural, historical, tourism, and } \\
\text { recreational purpose. }\end{array}$ & National & $\mathrm{V}$ & 11 & 4320.48 \\
\hline Regional park & $\begin{array}{l}\text { Landscape diversity protection, } \\
\text { sustainable development, and } \\
\text { tourism. }\end{array}$ & Regional & V & 2 & 1025.56 \\
\hline $\begin{array}{l}\text { Natural } \\
\text { monument }\end{array}$ & $\begin{array}{l}\text { Environmental protection; sci- } \\
\text { entific, aesthetic, or education- } \\
\text { al purpose. }\end{array}$ & $\begin{array}{l}\text { Regional } \\
\text { and local }\end{array}$ & III & 80 & 2.27 \\
\hline $\begin{array}{l}\text { Significant } \\
\text { landscape }\end{array}$ & $\begin{array}{l}\text { Protection of landscape val- } \\
\text { ue and biodiversity; protection } \\
\text { of cultural and historical value; } \\
\text { protection of landscape with pre- } \\
\text { served unique features; rest and } \\
\text { recreation. }\end{array}$ & $\begin{array}{l}\text { Regional } \\
\text { and local }\end{array}$ & V & 82 & 1331.28 \\
\hline Park forest & $\begin{array}{l}\text { Conservation of natural or plant- } \\
\text { ed forests of great landscape val- } \\
\text { ue; rest and recreation. }\end{array}$ & $\begin{array}{l}\text { Regional, } \\
\text { local }\end{array}$ & - & 27 & 29.54 \\
\hline $\begin{array}{l}\text { Horticultural } \\
\text { monument }\end{array}$ & $\begin{array}{l}\text { Preservation of a horticultural- } \\
\text { ly shaped space or plant(s) with } \\
\text { aesthetic, stylistic, artistic, cul- } \\
\text { tural, historical, ecological, or } \\
\text { scientific value. }\end{array}$ & Regional & - & 119 & 8.36 \\
\hline \multicolumn{5}{|c|}{ Area of protected areas within other protected areas } & 593.39 \\
\hline TOTAL & & & & 408 & 7528.03 \\
\hline
\end{tabular}

Sources: Marković, 2015, according to Zupan, 2012; Ministry of Environment and Energy of the Republic of Croatia, 2orga 


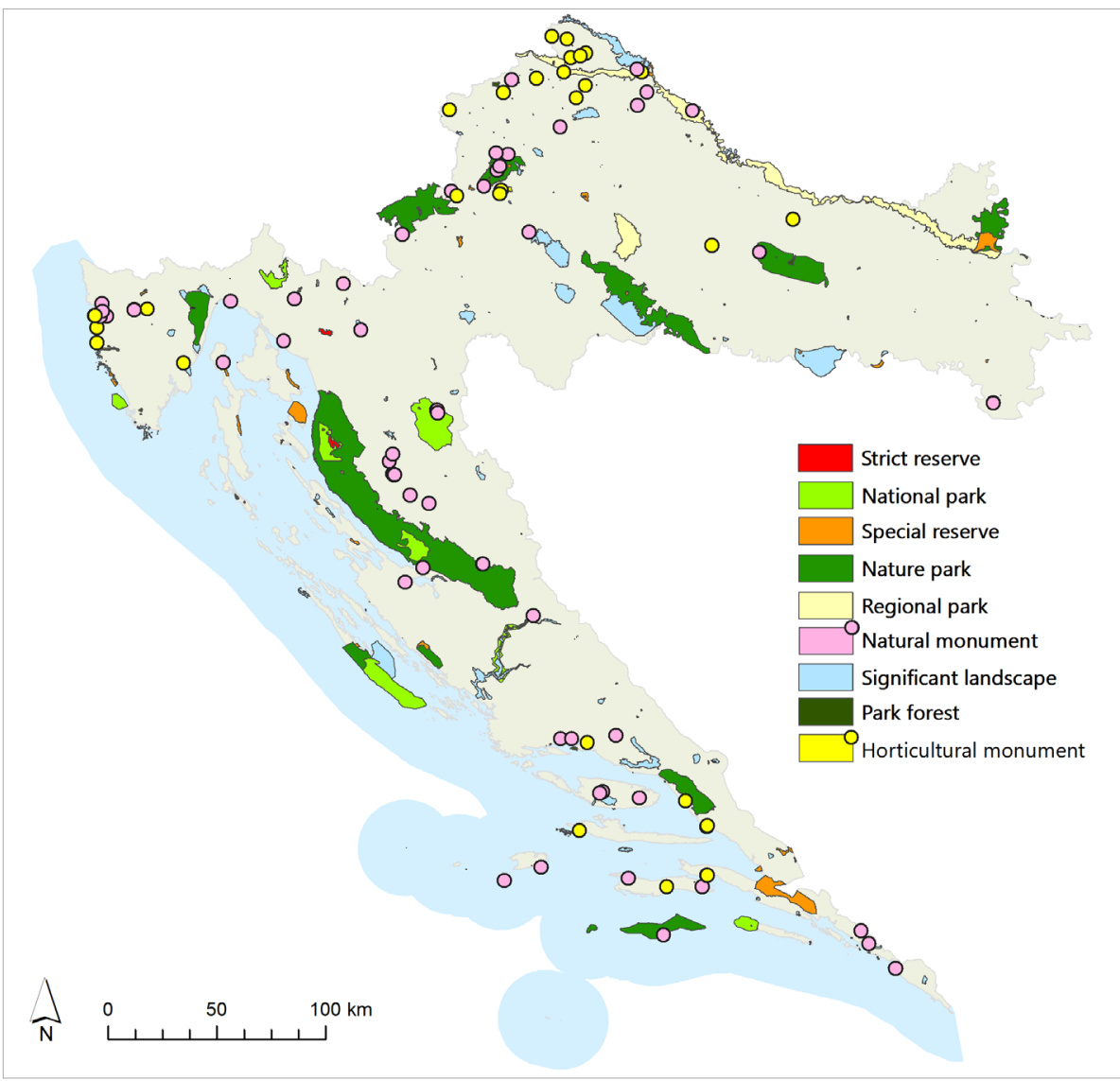

Fig. I Spatial distribution of protected areas in Croatia

Source: Ministry of Environment and Energy of the Republic of Croatia, 2019c

In regard to the level of management, the highest level (state) is characteristic for national parks, nature parks, strict reserves, and special reserves. As far as the level of protection goes, strict reserves are the most protected and are not meant for mass, organised tourist visits. This means that such areas are essentially irrelevant in terms of tourism valorisation. It can be said that national parks (Bralić, 200o) and nature parks-with regard to their size and intended use-are by far the most important and most-visited type of protected area in Croatia (See: Chapter 2). Namely, each national park and nature park is managed by the state via a competent public institution that is charged with nature protection and development of other economic activities like tourism, recreation, education, and promotion (Opačić et al., 2005). 
This serves to strengthen the institutional and financial sustainability of the national system of protected areas in Croatia, and also facilitates the cooperative marketing presentation of all Croatian national and nature parks included in the project "Parks of Croatia" (Ministry of Environment and Energy of the Republic of Croatia, 2017) (See: Chapter 11). This cooperative presentation and promotion on the tourism market has resulted in significant growth in the number of visitors to the parks in question over the last few years (See: Chapter 2).

It is worth mentioning that protected areas are declared in order to protect nature, and not to strengthen tourism and/or recreation. Sustainable tourism in most protected areas, however, is a welcome activity, as shown in Tab. 2. Thereby, with regard to leisure activities, it is worth differentiating the role of national parks, which attract both foreign and domestic tourists (Vidaković, 2003), from nature parks-some of which are more oriented toward tourism, while others are oriented toward recreation on the part of the local population (Opačić et al. 2014). National parks distinguish themselves in terms of attractiveness and number of visitors, like other protected areas that have been recognised by UNESCO as exceptionally valuable and given the status of World Heritage Site (e.g. Plitvice Lakes National Park in Croatia and Škocjan Caves Regional Park in Slovenia) (Holden, 2013).

The majority of remaining categories of protected areas in Croatia are not included in the tourism and/or recreation supply to the same degree, rather they have a conservational and educational role that stem from their value as part of Croatia's natural heritage. Such areas are managed by public institutions that have been founded in each of Croatia's 21 counties (regional-level management), and in some cases by cities, towns, municipalities, and special public institutions.

According to the Nature Conservation Act (1999), protected areas of nature in Slovenia are, on a basic level, divided into larger (national park, regional park, landscape park) and smaller areas (strict natural reserve, nature reserve, natural monument). The categories of all protected areas, their purpose and compliance with the IUCN categorisation are shown in Tab. 3, while their spatial distribution in Slovenia is shown in Fig. 2. 
Tab. 3 Types of protected areas in Slovenia

\begin{tabular}{|c|c|c|c|c|}
\hline $\begin{array}{c}\text { Category } \\
\text { of protection }\end{array}$ & Purpose & $\begin{array}{c}\text { IUCN } \\
\text { category }\end{array}$ & $\begin{array}{c}\text { Number } \\
\text { of areas }\end{array}$ & $\begin{array}{c}\text { Surface } \\
\left(\mathrm{km}^{2}\right)\end{array}$ \\
\hline National park & $\begin{array}{l}\text { A large area with many natural values } \\
\text { and with a high level of biodiversity cov- } \\
\text { ering the majority of the national park; } \\
\text { the original nature with preserved eco- } \\
\text { systems and natural processes is present; } \\
\text { there may also be areas in a smaller por- } \\
\text { tion of the national park of greater hu- } \\
\text { man influence, which is in harmony with } \\
\text { nature. }\end{array}$ & $\begin{array}{l}\text { II (at least } \\
75 \% \text { ) and } \\
\text { V (a max- } \\
\text { imum of } \\
25 \%)\end{array}$ & 1 & 839.82 \\
\hline Regional park & $\begin{array}{l}\text { An extensive area of regionally impor- } \\
\text { tant ecosystems and landscapes with } \\
\text { larger parts of the original nature and ar- } \\
\text { eas of natural values, which are inter- } \\
\text { twined with areas of nature where hu- } \\
\text { man influence is greater. }\end{array}$ & $\begin{array}{l}\text { V (at least } \\
75 \%) \text {, and } \\
\text { II (a max- } \\
\text { imum of } \\
25 \%)\end{array}$ & 3 & 429.91 \\
\hline Landscape park & $\begin{array}{l}\text { An area with emphasised qualitative and } \\
\text { long-term interaction between man and } \\
\text { nature, which has many ecological and } \\
\text { landscape values, and/or a high level of } \\
\text { biodiversity. }\end{array}$ & $\mathrm{V}$ & 46 & 1299.71 \\
\hline Strict natural reserve & $\begin{array}{l}\text { An area of naturally conserved geotopes, } \\
\text { habitats of endangered, rare or charac- } \\
\text { teristic plant or animal species, or an } \\
\text { area importance for the conservation of } \\
\text { biodiversity, where natural processes oc- } \\
\text { cur without human impact. }\end{array}$ & $\mathrm{I}$ & 1 & 0.02 \\
\hline Nature reserve & $\begin{array}{l}\text { An area of geotopes, habitats of endan- } \\
\text { gered, rare, or typical plant or animal } \\
\text { species, or an important area for the con- } \\
\text { servation of biodiversity, which is also } \\
\text { maintained through balanced human ac- } \\
\text { tivity in nature. }\end{array}$ & IV & 56 & 54.96 \\
\hline Natural monument & $\begin{array}{l}\text { An area containing one or more natural } \\
\text { values that have exceptional shape, size, } \\
\text { content, or position, or are a rare exam- } \\
\text { ple natural values. }\end{array}$ & III & 1164 & 192.69 \\
\hline TOTAL & & & 1271 & 2817.11 \\
\hline
\end{tabular}

Sources: Berginc et al., 2006; Sovinc et al., 2011; Slovenian Environment Agency, 2019

Protected areas in Slovenia amount to $2,817.11 \mathrm{~km}^{2}$ (in 2019), thus covering $\mathbf{1 3 . 9 \%}$ of Slovenia's surface area (Slovenian Environment Agency, 2019). Considering the relationship between protection and development, protected areas in Slovenia can be classified into 4 groups (Lampič et al., 2011, 6o-61): 1) protected areas in which protection excludes development (strict 


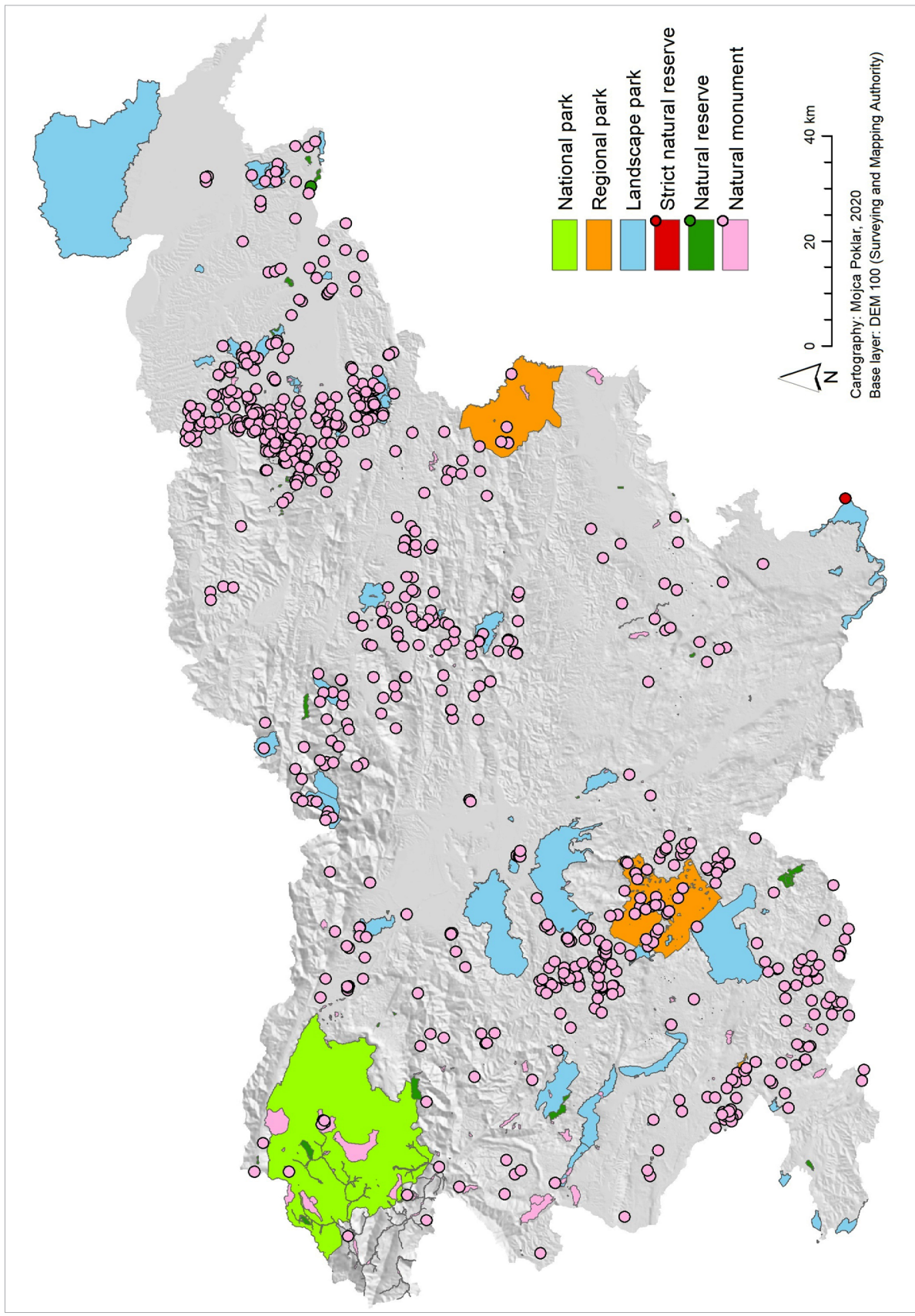

Fig. 2 Spatial distribution of protected areas in Slovenia Source: Slovenian Environment Agency, 2019 
nature reserves, IUCN type Ia and Ib); 2) category "equilibrium", where protection and development are equally important (regional and landscape parks, IUCN type V);3) conservation-oriented protected areas in which protection has priority over development (national parks, IUCN type II; natural monuments; IUCN type III); and 4) development-oriented protected areas, where development has priority, while respecting protection regimes, biodiversity, and important habitats (areas in Natura 2000 and ecologically significant areas).

Although the main role of protected areas can be attributed to the protection and conservation of nature (protection, maintenance, and restoration of habitats, as well as regular and continuous monitoring of the state of the park and its impact area), one cannot overlook their educational and research value, as well as their contribution to the development of the wider areas around them and human activities - aimed at greater socio-economic well-being in general (Hribar et al., 2011). As an example, tourist and recreational activities in protected areas can also be pointed out. In Slovenia, Triglav National Park plays a dominant role among protected areas, as it covers over 4 percent of the country's territory. Its leading role is also reflected in the category of nature protection (it is the only national park in Slovenia) and in tourist and recreational visits (Groznik Zeiler, 2011), as it is visited by over 2 million visitors annually (Triglav National Park, 2016). Other categories of protected areas register a significantly lower number of visitors; they are mostly visited by domestic visitors and tourists who usually visit a broad tourism area.

It should be mentioned that Slovenia has no regional administrative level of political governance, which is why only national and local levels of governance exist (although the plans for a regional administrative level of political governance were introduced in 2007). Despite this fact, there are three regional parks in Slovenia, which by definition represent large areas of regionally characteristic ecosystems and landscapes. They are managed by the municipalities (LAU 2) in which the protected areas are located, or by public institutions. Such level of protected area management can represent a problem in terms of financing, management, and organisation of work.

In both countries, a significant part of territory is also included in the Natura 2000 network, which is undoubtedly positive in terms of nature protection. The share of protected areas in Slovenia is $32.4 \%$ (Natura 2000, 2019) and in Croatia 29.3\% (Ministry of Environment and Energy of the Republic of Croatia, 2019b). In terms of tourism development, the areas of 
the Natura 2000 network that are also already protected under other categories of nature protection are very important. In the described context, such smaller protected areas (including those in Natura 2000 network) are usually declared to be of "local" importance and are therefore the concern of local communities-mainly municipalities. In such cases, the budget for protected areas is limited and protected areas are sometimes regarded as development restrictions by the local population (Mrak, 2008).

A comparison of the structure of protected areas in Croatia and Slovenia according to category shows quite a few differences between the two states. This is somewhat surprising because these are small, neighbouring states which share nearly identical natural regions (Pannonian lowlands, Dinarides, Adriatic coast). Apart from this, the most important part of the development of protected areas in both states actually took place when they were both part of the same state: the Socialist Federal Republic of Yugoslavia.

The category of nature park, which accounts for the largest portion of the total area of territory with protected status in Croatia, does not exist in Slovenia. The category that is most similar to the Croatian nature park category in Slovenia is either regional or landscape park, but there are major differences in the manner of management. The only category of protected area that, by definition and significance for ecology and tourism among protected areas, is essentially the same in both states is national park. It is interesting that this category also best corresponds to the IUCN definition, which confirms the key significance of national parks among protected areas on the global level. Furthermore, the major aforementioned differences, connected to levels of management of protected areas, stem from the lack of regional-level governance in Slovenia.

\section{Context and structure of the book}

At first glance, nature protection and tourism or recreation are incompatible activities. An increase in the number of visitors to a given protected area can have various negative impacts, like water, air, soil, and noise pollution, and reductions in the number and diversity of plant and animal species. This negatively influences biodiversity, and visually degrades the area (e.g. traffic and other tourism/hospitality infrastructure) (Mihalič, 2006; Cigale, 2009; Marković Vukadin, 2017).

Conversely, a protected area should be understood as a site of valuable natural heritage, and one of the most important functions of natu- 
ral (or cultural) heritage is to educate visitors. Protected areas are popularised by their inclusion in the tourism supply, thus becoming important goals for tourism and recreational mobilities. Under conditions of globalisation and the everyday stress of living in cities, the contemporary tourist is increasingly interested in learning about the values of local nature areas (Newsome et al., 2013) - especially protected areas. As a consequence of the aforementioned trend, there has been recognised growth in the significance of nature-based tourism (Coghlan and Buckley, 2013), ecotourism (Fennell, 2013), and tourism in protected areas specifically. 'Equally the term ecotourism should be understood as promotion of non-mass travel in naturally sensitive, protected areas where the visitor would raise public awareness towards preserving the natural environment and therewith, with its activities support the local community (Gosar, 2017, 3-4)'.

The aforementioned forms of tourism show numerous advantages, as they take place within paradigms of sustainable development, for both protected areas and the wider area, i.e. community or state. Namely, increased income (from tickets, souvenirs, guided tours, etc.) for protected areas ensures additional resources that, along with investment in nature protection, increase the value of the area in the long term (Bushell and McCool, 2007), and also influence increasing ecological awareness of visitors and the local population. From the aspect of tourism, the most attractive protected areas (e.g. Plitvice Lakes National Park or Triglav National Park) can become generators of tourism development and the entire economy of the wider area in which they are found, because their tourism branding also promotes the entire region and even the state itself. Thereby, a key precondition is that tourism capacity and the majority of its associated infrastructure should not be within the protected area.

It should be mentioned that the influence of such national parks on the wider area is not always positive. Regarding the example of the village Saborsko on the border of Plitvice Lakes National Park, Kušen and Klarić (2000) emphasised that the foundation of a national park can disrupt traditional rural systems, i.e. the daily lives of the local population. In this context, national parks can be seen as 'a foreign body in a previously unnoticed rural area' (Kušen and Klarić, 2000, 440)".

The main theme of this collection of research is comparative analysis of spatial development of tourism in protected areas in Croatia and Slovenia from a geographical perspective, in order to identify similarities and differences. Apart from confirmation of the spatial implications of tourism in 
protected areas in both states, another goal was to compare the development of tourism and its spatial influence and impacts in selected case studies. Guided by this objective, relevant experts on the topic of tourism in protected areas from both countries were invited to highlight the presented topic via their work on representative case studies.

Transport and transport infrastructure are an unavoidable precondition and development factor for tourism in all types of tourism areas, including protected areas. Therefore, the second chapter is dedicated to the topic of transport accessibility in Croatian national parks and nature parks. The authors examine its connection to tourist flow through analysis of five indicators, including public transport connectivity, public transport frequency, road transport connectivity, and temporal distance from urban areas and larger tourist centres.

Some national parks that are visited by a large number of tourists can be recognised as bearers of tourism, encompassing the wider area around the protected area itself. Examples of such national parks are Krka and Mljet national parks in Croatia. The research regarding Krka National Park presented in the third chapter, focuses on the development of rural tourism in its surrounding area, which has been characterised by intense development of rural tourism in recent years. The fourth chapter deals with the influence of tourism on the demographic development of the island Mljet in southern Dalmatia, which has become a popular tourism destination since its northwestern part was declared a national park in 1960. The research focuses on the socio-economic transformation and social pressure of tourism on a small local community.

Although the transformative role of tourism in lesser-known protected areas (most often those of a lower level of protection) is significantly weaker, wider knowledge of their conservational and educational role within the framework of nature-based tourism is very valuable and aids in guiding future development and management of protected areas. Additionally, it is also important to research the geographical aspects of recreational activities in protected areas, such as various forms of active recreation (mountaineering, fishing, birdwatching), as well as secondary housing. Protected areas on the Slovenian coast and in the Dinaric karst region are good examples for this.

The fifth chapter of this book discusses the influence of climate change on protected areas along the Slovenian coast. The Sečovlje Saltpans, Strunjan, and Debeli Rtič landscape parks and Škocjanski zatok Nature Reserve represent "islands of nature" in the mostly urbanised coastal zone 
of Slovenia, which is why they became important primarily as leisure areas and secondarily as tourism areas. With the goal of confirming possibilities for the development of nature-based tourism in rural areas of Kraški Rob, the sixth chapter of this book contains a scored assessment of the attractiveness of natural attractions and their tourism accessibility.

The seventh chapter of the book deals with second homes, as a form of recreation and potentially also of tourism in protected areas (Natura 2000). The described phenomenon is presented using the example of the village Sviščaki in forested area around Snežnik Mountain — the highest mountain in Slovenia that is outside of the Alps. Regarding the example of Škocjanski zatok Nature Reserve, the eighth chapter of the book shows the transformation of a once-degraded area in the vicinity of the port city Koper, which has become a protected marsh area with educational and tourism/recreational functions, due to the process of renaturalisation.

The last three chapters are dedicated to the planning of tourism and management in protected areas from the aspect of tourism in both states. The ninth chapter tackles spatial planning in tourism in protected areas in Slovenia, and primarily gives an overview of planning on different levels (national to local), before examining them using the examples of Škocjanski zatok Nature Reserve, Lipica (Natura 200o), and Škocjan Caves Regional Park. The tenth chapter discusses the interrelation between development, management, and management issues in Plitvice Lakes National Park - the most visited protected area in Croatia. In this chapter, phases of tourism development according to Butler's model (TALC) and the related management phases and approaches are presented.

The last chapter synthesises the main findings of the research presented in the previous chapters and integrates these findings into recommendations for future management of protected areas, in keeping with the concept of sustainable tourism.

\section{Conclusion}

It can be concluded that protected areas differ in intended purpose, in relation to both IUCN categorisation and categorisation in Croatia and Slovenia. One of the main differences between the Croatian and Slovenian systems of protected areas is that there are more types of protected areas in Croatia (9 in total) than in Slovenia (6 in total). In Croatia, there is a higher number of "large" protected areas (national parks, nature parks), while 
in Slovenia the number of small scale protected areas is higher $(1,164$ nature monuments).

There are also large differences in the scope and characteristics of tourism in individual categories of protected areas. Some of them (e.g. national parks) can satisfy a wide spectrum of tourism motivations with what they offer and, therefore, attract numerous tourists of general motivation, while other categories (e.g. natural monuments) generally only attract specific groups of visitors. In contrast, some protected areas with stricter protection regimes (e.g. strict natural reserves) essentially do not participate in the organised tourism supply, regardless of their inherent attractiveness and natural beauty. Finally, some protected areas (especially those in the vicinity of cities, e.g. nature parks or park forests) are ideal for recreation on the part of the local population and, in these areas, leisure/recreational activities are much more developed than tourism.

In the most-visited national parks tourism (often mass tourism-especially during the summer tourism season) has become the main factor of transformation of both protected areas and the areas surrounding them. Namely, the surrounding area brings both positive and negative changes, occasionally threatening nature protection imperatives, i.e. the fundamental function of all protected areas. In contrast, in lesser-known protected areas, i.e. those with a lower level of protection, tourism is the initial phases or not present, so their scientific, educational, and recreational functions are more strongly emphasised than tourism (commercial). As a specific dominant form of tourism in such areas, nature-based tourism stands out. The spatial reflection of such tourism is gentler and also has the effect of spreading ecological awareness and educating visitors.

\section{References}

Berginc, M., Kremesec Jevšenak, J., Vidic, J., 2006: Sistem varstva narave $v$ Sloveniji, Ministrstvo za okolje in prostor, Ljubljana.

Bralić, I., 200o: Turizam i nacionalni parkovi u Hrvatskoj, Turizam 48 (4), 373-378.

Bushell, R., McCool, S. F., 2007: Tourism as a tool for conservation and support of protected areas: setting the agenda, in: Tourism and protected areas: benefits beyond boundaries (eds. Bushell, R., Eagles, P.), CAB International, Oxfordshire - Cambridge, 12-26. 
Cigale, D., 2009: Turizem in rekreacija kot dejavnika okoljskih obremenitev, in: Okoljski učinki prometa in turizma v Sloveniji (eds. Špes, M., Ogrin, D.), Univerza v Ljubljani, Filozofska fakulteta, Ljubljana, 86-105.

Coghlan, A., Buckley, R., 2013: Nature-based tourism, in: The Routledge handbook of tourism and the environment (eds. Holden, A., Fennell, D.), Routledge, London - New York, 334-344.

Dudley, N. (ed.), 2008: Guidelines for applying protected area management categories, IUCN, Gland.

Fennell, D., 2013: Ecotourism, in: The Routledge handbook of tourism and the environment (eds. Holden, A., Fennell, D.), Routledge, London - New York, 323-333.

Gosar, A., 2017: Managing sustainable tourism in protected areas, in: Tourism in protected areas of nature in Serbia and Slovenia (eds. Filipović, D. et al.), University of Belgrade, Faculty of Geography, Belgrade, 3-11.

Groznik Zeiler, K., 2011: Razvojna vloga zavarovanih območij v Sloveniji, in: Razvoj zavarovanih območij v Sloveniji (eds. Nared, J. et al.), Geografski inštitut Antona Melika ZRC SAZU, Ljubljana, 23-32.

Holden, A., 2013: Protected areas and tourism, in: The Routledge handbook of tourism and the environment (eds. Holden, A., Fennell, D.), Routledge, London - New York, 276-284.

Hribar, M., Šmid Hribar, M., Erhartič, B., 2011: Premislek o razvoju in zavarovanih območjih, in: Razvoj zavarovanih območij v Sloveniji (eds. Nared, J. et al.), Geografski inštitut Antona Melika ZRC SAZU, Ljubljana, 11-21.

Klarić, Z., Gatti, P., 2006: Ekoturizam, in: Hrvatski turizam: plavo, bijelo, zeleno (eds. Čorak, S., Mikačić, V.), Institut za turizam, Zagreb, 149-165.

Kušen, E., Klarić, Z., 200o: Razvoj turizma u rubnim područjima nacionalnih parkova: primjer Saborsko, Turizam 48 (4), 439-446.

Lampič, B., Mrak, I., Plut, D., 2011: Geographical identification of development potential for the sustainable development of protected areas in Slovenia, Hrvatski geografski glasnik 73 (2), 49-65, DOI: 10.21861/hgg.2011.73.02.04.

Leung, Y. F., Spenceley, A., Hvenegaard, G., Buckley, R. (eds.), 2018: Tourism and visitor management in protected areas: guidelines for sustainability, Best Practice Protected Area Guidelines Series No. 27, IUCN, Gland.

Marković, I., 2015: Problemi i mogućnosti održivoga upravljanja zaštićenim prirodnim područjima: primjer Nacionalnoga parka Plitvička jezera, 
Doctoral Thesis, University of Zagreb, Faculty of Science, Department of Geography, Zagreb.

Marković Vukadin, I., 2017: Sustainability issues in management of tourism in protected areas: case study of Plitvice Lakes National Park, in: Evolution of destination planning and strategy: the rise of tourism in Croatia (eds. Dwyer, L. et al.), Palgrave Macmillan, Cham, 201-219, DOI: 10.1007/978-3-319-42246-6_10.

Mihalič, T., 2006: Trajnostni turizem, Ekonomska fakulteta, Ljubljana.

Ministry of Environment and Energy of the Republic of Croatia, 2017: Projekt PARCS - pregled rezultata, Zagreb.

Mrak, I., 2008: Small size protected areas - development potentials of Slovenia, Hrvatski geografski glasnik 70 (1), 5-23, DOI: 10.21861/hgg.2008.70.01.01.

Newsome, D., Moore, S. A., Dowling, R. K., 2013: Natural area tourism: ecology, impacts and management, Channel View Publications, Bristol - Buffalo - Toronto.

Opačić, V. T., Curić, D., Jandras, M., Kutle, K., Marijan, N., Mirt, I., Perković, D., Vodanović, I., 2014: Zaštićena područja kao rekreacijske zone grada primjer Parka prirode Medvednica, Hrvatski geografski glasnik 76 (1), 6187, DOI: 10.21861/HGG.2014.76.01.04.

Opačić, V. T., Lukić, A., Fuerst-Bjeliš, B., 2005: Sustainable development of recreation and tourism in the protected areas of Croatia: issues and indicators, Problemi na geografijata 3-4, 209-223.

Sovinc, A., 2017: Explanatory notes on international standards for planning tourism and use of natural resources in some categories of protected areas, in: Tourism in protected areas of nature in Serbia and Slovenia (eds. Filipović, D. et al.), University of Belgrade, Faculty of Geography, Belgrade, 13-26.

Sovinc, A., Fišer, Pečnikar, Ž., Gosar, A., 2011: Govorimo isti jezik? Primerjava mednarodnih in slovenskih meril kategorizacije zavarovanih območij, in: Razvoj zavarovanih območij v Sloveniji (eds. Nared, J. et al.), Geografski inštitut Antona Melika ZRC SAZU, Ljubljana, 33-40.

Vidaković, P., 2003: Nacionalni parkovi i zaštićena područja u Hrvatskoj, Fond za stipendiranje mladih za zaštitu prirode i turizam Zagreb - 1990, Zagreb.

\section{Sources}

Ministry of Environment and Energy of the Republic of Croatia, 2019a: Croatian Agency for the Environment and Nature, Zagreb, http://www. 
haop.hr/hr/tematska-podrucja/zasticena-podrucja/zasticena-podrucja/ zasticena-podrucja-u-rh (28. 11. 2019)

Ministry of Environment and Energy of the Republic of Croatia, 2019b: Natura 2000 Network Database, Croatian Agency for the Environment and Nature, Zagreb.

Ministry of Environment and Energy of the Republic of Croatia, 2019c: Nature Protection Database, Croatian Agency for the Environment and Nature, Zagreb.

Natura 2000, 2019: Natura 2000 v Sloveniji, http://www.natura2ooo.si/index. php?id $=45$ (29. 11. 2019)

Nature Conservation Act, 1999: Uradni list RS 56/99.

Republic of Croatia, 2013: Nature Protection Act, Official Gazette 80/2013.

Slovenian Environment Agency, 2019: http://kazalci.arso.gov.si/sl/content/zavarovana-obmocja- 4 ?tid $=40$ (o9. 12. 2019)

Triglav National Park, 2016: Management Plan for the Triglav National Park 2016-2025, https://www.tnp.si/assets/Javni-zavod/Nacrt-upravljanja/JZTNP-Nacrt-upravljanja-TNP-2016-2025.pdf (22. 11. 2019) 



\title{
Chapter 2
}

Transport accessibility as a factor of tourist flow in Croatian national parks and nature parks

\author{
Slaven Gašparović, Vuk Tvrtko Opačić
}

\section{Abstract}

The aim of the chapter is to assess transport accessibility and examine its connection to tourist flows in Croatian national parks and nature parks. The research included 16 of the 19 Croatian national parks and nature parks, i.e. those for which it was possible to identify the entrances used by the majority of visitors. The assessment of transport accessibility for these 16 entrances to protected areas was conducted using the following indicators: a) public transport connectivity (bus, ship/catamaran/ferry); b) public transport frequency; c) road transport connectivity; d) temporal distance from cities/towns; and e) temporal distance from larger tourist centres. The scoring of individual indicators for each protected area was determined and the protected areas were ranked accordingly. In order to determine the connection between transport accessibility and tourist flow, a correlation analysis was conducted for each national park and nature park, with the transport accessibility score as the independent variable and the number of visitors as the dependent variable.

Key words: transport accessibility, tourist flow, national park, nature park, sustainable development, geography, Croatia 


\section{Introduction}

Although they are not considered to be a basis of tourism attraction, transport accessibility, transport connectivity, and transport infrastructure are highly significant preconditions for creating and developing a tourism destination (Prideaux, 2000; Kušen 2002; 2010; Čavlek et al., 2011). The intensity of tourist flow is often proportionate to transport accessibility, quality of transport connectivity, and infrastructure in a tourism destination. However, increasing traffic volume caused by the expansion of tourist travel in popular tourism destinations leads to ecological and financial challenges. Although the concept of sustainable tourism development, which facilitates spending leisure time in a clean and peaceful environment, is currently imposed as an essential approach to tourism destination management, it is becoming practically unachievable for more and more tourism destinations. Along with problems arising from high costs of transport infrastructure construction and maintenance (e.g. motorways, modern airports, quality rail network, cruise ship terminals, car parks), traffic in tourism destinations today frequently has a negative impact on the environment (Müller, 2004).

With the purpose of satisfying motives to spend leisure time in ecologically clean and peaceful surroundings and also learn about natural heritage, protected areas are becoming increasingly popular sights/destinations in the modern tourism and recreation supply. The rise of popularity of protected areas in the tourism demand is concurrent with the increase in conflicts between their transport accessibility and connectivity as preconditions for a higher number of visitors, and sustainable tourism development imperatives that require special attention in managing protected areas. It is noteworthy to emphasise that these areas are not characterised as protected for promotion of their most valuable parts of natural heritage, rather for their protection and preservation for future generations.

National parks and nature parks represent one of the largest and most visited categories of protected areas in Croatia in terms of surface area (Bralić, 2000; Klarić and Gatti, 2006; Opačić et al., 2014), so the conflicts between their transport accessibility as a factor of tourism flow and their sustainable development are most pronounced (Fig. 1).

According to data from the Nature Protection Database of the Ministry of Environment and Energy of the Republic of Croatia (2017), protected areas in Croatia encompass $7,528.03 \mathrm{~km}^{2}(8.54 \%$ of Croatian territory, including territorial seas). National parks $\left(979.63 \mathrm{~km}^{2}\right.$ in total) and nature parks 


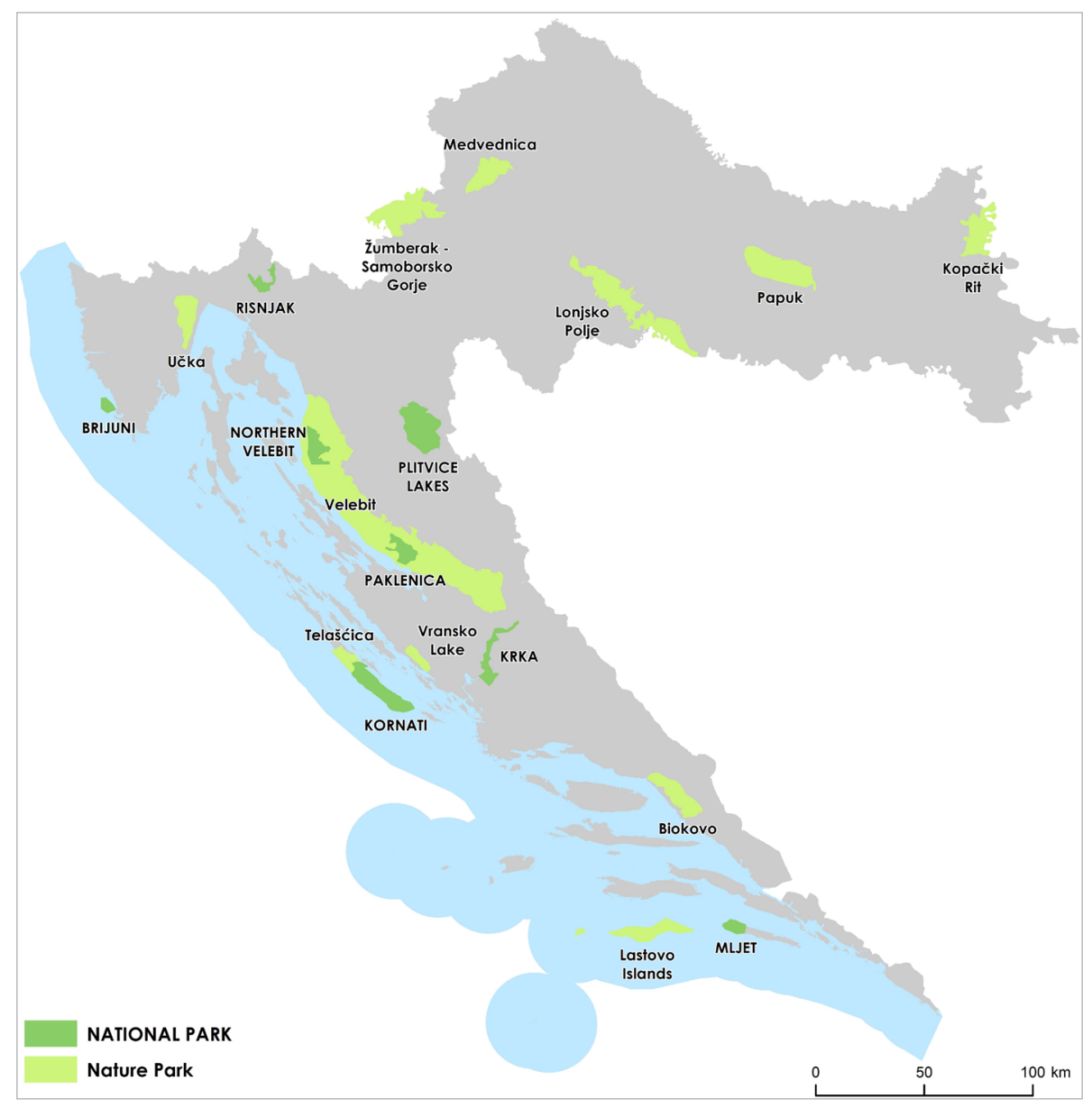

Fig. I National parks and nature parks in the Republic of Croatia

$\left(4,320.48 \mathrm{~km}^{2}\right.$ in total) together encompass $5,300.11 \mathrm{~km}^{2}$, i.e. $70.41 \%$ of the entire area of all protected areas in Croatia, and in 2018 they were visited by 4,444,063 visitors (Ministry of Environment and Energy of the Republic of Croatia, 2019).

The increasing transport accessibility of national parks and nature parks directly and indirectly impacts their sustainable development. For example, one of the most visible direct negative impacts of increased transport accessibility is the construction of transport infrastructure, which irreversibly changes the natural environment, and for which there are increasing spatial demands (Daigle and Zimmermann, 2004; Opačić et al., 
2005). Simultaneously, ecologically valuable space within the borders of national parks (Monz et al., 2016) and nature parks, and their immediate surroundings is exhausted, which shrinks the habitats of numerous plant and animal species (Ament et al., 2008).

Marković Vukadin (2017) recognised the three most negative consequences of the increase in mass visits to national and nature parks: the increase in solid waste; wastewater; and transport. Within the context of Plitvice Lakes National Park, through which state road $\mathrm{D} 1{ }^{\mathrm{I}}$ passes, Marković (2015) also emphasised the problem of visitor safety in the national park due to the increased number of vehicles present on the state road. Increased toxic gas emissions, caused by the combustion of fossil fuels, produces air, water, and land pollution. Additionally, noise pollution and light pollution are also increasing (Müller, 2004; Newsome et al., 2013).

The indirect negative impact of transport on national parks and nature parks that has arisen from the increase in their transport accessibility is reflected in the increase in the number of visitors primarily to the most attractive zones (the zones of the fundamental phenomena, due to which a particular area was characterised as protected). Consequently, there has been an increase in the amount of solid and liquid waste (e.g. sewage), as well as damage to fundamental phenomena (e.g. travertine barriers in Plitvice Lakes and Krka national parks) (Opačić et al., 2005). From the tourism demand aspect, the increased number of visitors during the peak season negatively impacts the general tourist experience, which creates a negative perception of overcrowding in Croatia's protected areas.

Moreover, tourist flow in national and nature parks is characterised by extreme spatial and temporal concentration, which increases negative impacts on the environment (Gosar, 2017). Namely, the highest visitor pressure is directed to the zones of fundamental phenomena, and on a yearly level (during peak season) and weekly level (certain weekdays) (Williams, 2003), which the management boards of individual protected areas try to mitigate by raising the entrance fees in peak season and limiting the daily number of visitors or the number of visitors allowed in the protected area simultaneously (Plummer, 2009). On the other hand, a smaller number of tourists and recreational visitors in some national parks and nature parks

1 In Croatia, roads are categorised as follows (labelled with a letter and a number): motorway = autocesta $(\mathrm{Ax})$; state road = državna cesta $(\mathrm{Dx})$; county road = županijska cesta $(\check{Z} \mathrm{x})$; local road = lokalna cesta $(\mathrm{Lx})$. For the purpose of this chapter, the Croatian abbreviated labels of individual roads will be used, e.g. state road D1. 
may be due to their weaker transport accessibility, as one of the main limiting factors of tourist visits.

For an optimal management of national parks and nature parks it is necessary to implement planning of sustainable transport, which means:

a) minimising atmospheric pollution;

b) minimizing noise;

c) minimizing land use conversion;

d) minimizing the direct impacts of visitation on the environment;

e) minimizing the impacts of visitation on the recreational experience;

f) safeguarding the visual perception of naturalness;

g) enabling all visitor groups to move freely;

h) ensuring the protection of the local communities' quality of life; and

i) ensuring financial sustainability (Orsi, 2015b).

As good practice examples, we can state "stick measures", i.e. minimising and limiting car and bus traffic while simultaneously encouraging "carrot measures", i.e. marketing and visitor education with strengthened bus transport to protected areas and organised shuttle transport within protected areas, as well as bicycle traffic (Eaton and Holding, 1996; Cullinane, 1997; Cullinane and Cullinane, 1999; Daigle, 2008; Collum and Daigle, 2015; Guiver et al., 2015; Orsi, 2015a; Weston et al., 2015). Within the context of promoting desirable modes of transport in protected areas there has been an increased level of discussion regarding the concept of so-called "slow travel", based on pedestrian traffic, bicycle traffic, and some forms of rail, river and sea traffic, as well as bus traffic, whereby visitors can have deep experiences of the beauty of protected areas (Dickinson and Lumsdon, 2010).

Transport accessibility is viewed through three components (origin link - destination) and can be defined from two aspects: as the ease by which an individual or group can reach one or several opportunities, and the ease by which a destination can be reached generally. Considering that transport accessibility is a broad and flexible concept, characterised by a high level of complexity, there are several indicators that can be used in measuring it. Transport accessibility measurement indicators can be simple (e.g. number of public transport stops within an area, the length of a given road), but also more complex, including a time component, trans- 
port organisation level, etc. (Geurs and Ritsema van Eck, 2001; Halden et al., 2005; Litman, 2007; Halden, 2011).

In order to determine whether there is indeed an impact, and the extent to which transport accessibility is linked to the intensity of tourist flow in Croatian national parks and nature parks, it is first necessary to define measurable indicators of transport accessibility assessment, applicable in national parks and nature parks in Croatia. Afterwards, their scoring should be implemented in each researched national park/nature park and, finally, the total scores for each researched protected area should be compared to the number of visitors.

\section{Research aims and methodology}

The aim of the chapter is to assess transport accessibility in Croatian national parks and nature parks and examine its connection to tourist flow ${ }^{2}$ in the stated protected areas. The research is based on the hypothesis that the protected areas with higher transport accessibility have a higher number of tourist visits than those with lower transport accessibility. The research included 16 of the 19 Croatian national parks and nature parks, i.e. those for which it was possible to identify the entrances used by the majority of visitors. The research included the following national parks: Brijuni; Krka; Mljet; Paklenica; Plitvice Lakes; Risnjak; and Northern Velebit. Kornati National Park was excluded due to being an insular area for which it was impossible to determine a single point of entrance used by the majority of visitors. Apart from national parks, the following nature parks were included in the research: Biokovo; Kopački Rit; Lastovo Islands; Lonjsko Polje; Medvednica; Papuk; Telašćica; Učka; and Vransko Lake. Velebit and Žumberak-Samoborsko Gorje nature parks were excluded from the research as it proved impossible to identify which entrance was used by the majority of visitors.

2 Throughout the chapter, the term tourist flow in a protected area refers to the total number of visitors who stay for one or more nights within a protected area as well as day-trippers (tourists who are staying at tourism destinations nearby, one-day excursionists, as well as the local population living in settlements nearby and visiting the protected area for recreation). Likewise, it's important to point out that for some researched protected areas, mainly national parks that charge entrance fees and nature parks close to coastal and insular tourism destinations (e.g. Biokovo, Velebit, Telašćica, Lastovo Islands), more pronounced "real” tourist motivation during a visit could be observed; whereas other researched protected areas, mainly nature parks that do not charge entrance fees (e.g. Medvednica, Žumberak-Samoborsko Gorje), show a more pronounced recreational motivation among visitors was detected. 
The assessment of transport accessibility for the 16 entrances to protected areas researched in this paper was conducted using the following indicators:

a) public transport connectivity (bus, ship/catamaran/ferry);

b) public transport frequency;

c) road transport connectivity;

d) temporal distance from cities/towns; and

e) temporal distance from larger tourist centres.

Considering that some tourists arrive at protected areas by public transport, the first indicator for assessing transport accessibility was the public transport connectivity of each protected area. In order to determine its public transport connectivity, the cartographic analysis with Google Maps (Google Maps, 2019) was used to determine the existence of public transport stops for bus transport and ship/catamaran/ferry ports, within a maximum buffer of $800 \mathrm{~m}$ (which corresponds to a 10-minute walking distance) from the entrance mostly used by visitors. Even though a 400 $m$ distance (i.e. a 5-minute walking distance) is often considered adequate for using public transport (e.g. Murray and Wu, 2003; Hurni, 2006; 2007; Kimpel, 2007), this distance is usually used in the study of public transport accessibility in cities. Some authors consider that the longer distance, in this case $800 \mathrm{~m}$ (i.e. a 10-minute walk), from a public transport stop can also be taken into consideration, e.g. in research by Murray et al. (1998) and Hurni $(2006 ; 2007)$. In this research it is assumed that the tourists who arrive at the protected area are willing to walk for a maximum of $800 \mathrm{~m}$, or 10 minutes, from a public transport stop to the entrance of a protected area ${ }^{3}$.

Regardless of the existence of a public transport stop within $800 \mathrm{~m}$ of the protected area, the frequency of public transport was also an impor-

3 For the purposes of this research, places in an extended sense (settlements, localities) rather than strict geographical locations /coordinates of the gates were taken as the entrances to the protected areas. Considering this, when assessing the connectivity of a protected area by public transport, the distance of the gate itself from the public transport station could be taken into account and the connectivity by public transport could be assessed in two categories (strong and weak connectivity). In the case of Croatian protected areas, the following national and nature parks would have weak connectivity, where the distance of the gate is more than 800 meters (or a 10-minute walk) from the nearest public transport station: Risnjak; Paklenica; and Krka national parks, as well as Telašćica and Vransko Lake nature parks, but the research results and conclusions were not affected. Taking into account the other analysed indicators, the selection of entrances to protected areas, which are described in detail below, could be considered as well-grounded. 
tant factor in studying transport accessibility of the protected area. Public transport frequency impacts a range of activities of its users. For this purpose, public transport frequency of the busiest day in the season was taken as an accessibility indicator. For example, public transport frequency impacts passenger waiting time (especially in case of stopovers), as well as how people organise their plan for activities corresponding to departures/arrivals of public transport. A higher frequency of public transport makes it easier for visitors to plan their visit, as well as organise their time.

In addition to public transport, visitors to protected areas also use personal vehicles. For them, road infrastructure is of high importance, especially in terms of road category (motorway, state road, county road, local road), together with the width and quality of the road. Road category (with all its parameters) affects the speed, safety, and quality of the journey, but also the connectivity of the protected area with the rest of the country. The assumption is that a higher road category means better quality, which enables greater safety and speed of travel-meaning better transport accessibility. Therefore, the road transport connectivity indicator was taken as one of the parameters of transport accessibility. It was determined in terms of road category leading to the entrance to the protected area.

Cities play a significant role in tourist travel as departure/arrival and/ or transit points. From a transport point of view, cities include transport terminals and ports for short or long journeys, and lines of public transport at the local, regional, national, and international levels. This is why they often play an important role as departure points to protected areas. The assumption was that the vicinity of cities/towns would lead to an increase in the number of visitors to the nearby protected area. Therefore, the time distance by car/ship between the protected area and the closest settlement with the administrative status of city/town was taken as one of the accessibility indicators. In this case, time distance was measured considering that a smaller spatial distance does not necessarily signify a shorter temporal distance and vice versa. This approach is in line with new tendencies in transport accessibility studies (e.g. Kaza, 2015). Temporal distance values in this research were determined using Google Maps (Google Maps, 2019).

In accordance with the previous indicator, it can be assumed that the vicinity of a leading tourist centre will lead to an increased number of visitors to a protected area. A leading tourist centre means a greater possibility of using transport services and, like in the case of the previous indicator, its temporal distance from a protected area was taken as one of the indica- 
tors of transport accessibility. In this sense, a leading tourist centre in the coastal area means a local self-government unit (city/municipality) with at least 1,000,00o overnight stays a year or in continental part of Croatia with at least 100,00o overnight stays a year in 2018 (Croatian Bureau of Statistics, 2019).

After determining assessment indicators for transport accessibility of protected areas, each were scored on a point scale (Tab. 1). The scoring of transport accessibility indicators of protected areas in the context of tourist flow is related to similar methodological approaches in geographic research. Fyhri and Hjorthol (2009), for example, assessed the impact of various indicators on mobility of social groups, while Casas et al. (2009) assessed transport-based social exclusion on the availability of living opportunities. Also, D'Haese et al. (2011) used the assessment method to determine the impact of distance and environmental criteria to active travel. The main advantages of this methodological approach are spatial and topic applicability, while the main disadvantage is that there can be subjectivity in creating indicators and scoring.

Tab. I Indicators for assessing transport accessibility of protected areas and their scoring

\begin{tabular}{|c|c|}
\hline Public transport frequency & $\begin{array}{l}1=1-2 \text { daily departures } \\
2=3-5 \text { daily departures } \\
3=6 \text { or more daily departures }\end{array}$ \\
\hline Road connectivity of the protected area & $\begin{array}{l}1=\text { local } \operatorname{road}(\mathrm{L}) \\
2=\text { county } \operatorname{road}(\check{Z}) \\
3=\text { state } \operatorname{road}(\mathrm{D}) \\
4=\text { motorway }(\mathrm{A})\end{array}$ \\
\hline Temporal distance from the protected area to nearby city/town & $\begin{array}{l}1=\text { more than } 60 \text { minutes } \\
2=46-60 \text { minutes } \\
3=31-45 \text { minutes } \\
4=16-30 \text { minutes } \\
5=\text { up to } 15 \text { minutes }\end{array}$ \\
\hline $\begin{array}{l}\text { Temporal distance from the protected area to leading tourist } \\
\text { centres }\end{array}$ & $\begin{array}{l}1=\text { more than } 60 \text { minutes } \\
2=46-60 \text { minutes } \\
3=31-45 \text { minutes } \\
4=16-30 \text { minutes } \\
5=\text { up to } 15 \text { minutes }\end{array}$ \\
\hline
\end{tabular}


The scoring of individual indicators for each protected area was determined with consideration to the total number of points and protected areas were ranked (whereby a higher number of points indicates a higher score of transport accessibility). In order to determine the connection between transport accessibility and tourist flow, a correlation analysis of each protected area's score of transport accessibility and the number of visitors according to data from the Ministry of Environment and Energy of the Republic of Croatia was conducted. Then the Pearson correlation coefficient, with the score of transport accessibility as the independent variable and the number of visitors as the dependent variable, was calculated.

\section{Transport accessibility assessment for protected areas}

The assessment of specific indicators of transport accessibility, as well as the total score of transport accessibility for analysed national parks and nature parks are shown in Tab. 2.

The highest scores of transport accessibility among national parks were achieved by Plitvice Lakes and Krka national parks. The entrances to Plitvice Lakes National Park are located along state road D1, which allows for high accessibility, by both public and private transport. State road D1 is highly significant in terms of the transport connectivity of the Republic of Croatia considering that it connects the border crossing Macelj (on the border with Slovenia) and Split. Regarding the location of the entrance to Plitvice Lakes National Park next to state road D1, there is a range of bus lines connecting the continental part of Croatia with the Croatian Littoral that pass by the entrance and serve as connections to Plitvice Lakes National Park (there are at least ten separate daily departures that pass through the Park). Since it is a state road, it has better quality and safety than the county roads that access some of the protected areas of Croatia. In accordance with the research methodology, although Plitvice Lakes National Park is not located in the vicinity of larger urban centres nor leading tourist centres, it was regarded as an individual city/town, i.e. as an individual tourist centre, in and of itself, for the purposes of the research described in this chapter.

Krka National Park also achieved a high score of transport accessibility, identical to Plitvice Lakes National Park. As opposed to other national parks and nature parks, the entrance to Krka National Park is located in the immediate vicinity of motorway A1, which connects Zagreb and Ploče, enabling exceptional transport connectivity on the national and regional scale for both public and private transport. Considering that one of 
Tab. 2 The assessment of transport accessibility of national parks and nature parks according to indicators

\begin{tabular}{|c|c|c|c|c|c|c|}
\hline Protected area & 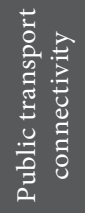 & 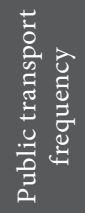 & 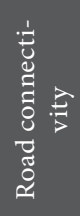 & 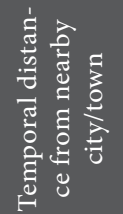 & 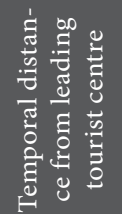 & ت્ّ \\
\hline Plitvice Lakes & 1 & 3 & 3 & 5 & 5 & 17 \\
\hline Krka & 1 & 3 & 4 & 5 & 4 & 17 \\
\hline Brijuni & 1 & 3 & 3 & 4 & 5 & 16 \\
\hline Kopački Rit & 1 & 3 & 2 & 5 & 5 & 16 \\
\hline Vransko Lake & 1 & 3 & 3 & 4 & 4 & 15 \\
\hline Medvednica & 1 & 3 & 2 & 4 & 4 & 14 \\
\hline Paklenica & 1 & 3 & 3 & 3 & 3 & 13 \\
\hline Telašćica & 1 & 2 & 3 & 3 & 3 & 12 \\
\hline Risnjak & 1 & 1 & 3 & 4 & 2 & 11 \\
\hline Lastovo Islands & 1 & 3 & 3 & 1 & 1 & 9 \\
\hline Lonjsko Polje & 1 & 2 & 1 & 4 & 1 & 9 \\
\hline Mljet & 1 & 2 & 3 & 1 & 1 & 8 \\
\hline Northern Velebit & $\mathrm{o}$ & o & 2 & 3 & 1 & 6 \\
\hline Papuk & o & o & 2 & 3 & 1 & 6 \\
\hline Učka & o & o & 2 & 2 & 2 & 6 \\
\hline Biokovo & o & $\mathrm{o}$ & 1 & 1 & 1 & 3 \\
\hline
\end{tabular}

the main entrances to Krka National Park is located in Skradin, transport accessibility within the context of the vicinity to an urban centre is high. There are several bus lines with approximately ten daily departures passing through Skradin. The leading tourist centre as an indicator of transport accessibility of Krka National Park, however, is Šibenik, which is about 20 minutes away by car.

Brijuni National Park has the next highest transport accessibility score. The entrance to Brijuni National Park is the coastal settlement Fažana, which was also taken as a leading tourist centre in the analysis. In its immediate vicinity is state road D21, leading from the border crossing Kaštel (on the border with Slovenia) to Pula, which enables significant transport accessibility. Pula, the nearest urban centre, is the main point of origin of public transport to Fažana, with more than ten daily departures. Fažana is, 
however, more than 15 minutes distant from Pula by car, which resulted in a lower score of transport accessibility compared to Plitvice Lakes National Park and Krka National Park.

The main entrance to Paklenica National Park is the coastal settlement Starigrad on state road D8 (a.k.a. the Adriatic Highway) located 1.5 $\mathrm{km}$ from the gate of Park. State road D8 runs from the border crossing Rupa (on the border with Slovenia) to the border crossing Karasovići (on the border with Montenegro). The proximity of this road enables easy access by public or private transport, whereby there are about ten bus lines departing daily from Starigrad in the direction of either Rijeka or Zadar. However, the greater distance from urban and leading tourist centres lowers the total score of transport accessibility of Paklenica National Park. Zadar, the closest urban centre and leading tourist centre, is a bit less than 45 minutes from Starigrad by car.

The village Crni Lug (1.5 km from the gate of national park) was selected as the main entrance to Risnjak National Park. Although it is located on state road $\mathrm{D}_{32}$ (which runs from the border crossing Prezid, on the border with Slovenia, to Delnice), public transport is not significantly developed. There are only two daily bus line departures on this road. Furthermore, Delnice, the closest urban centre, is located more than 15 minutes away by car; while Crikvenica, the closest leading tourist centre, is a bit less than one hour away from Risnjak National Park by car. It is also noteworthy that there is no direct bus connection from Crikvenica to the Park.

Mljet National Park, as opposed to Brijuni, is located further from the coast. Additionally, the area of the Park does not cover the entire island. Therefore, the main entrance to the national park is a village on the island called Polače. State road D120 passes through the entire island and through the Park. Polače is connected to the rest of the island Mljet with two daily bus line departures and two daily catamaran departures toward Dubrovnik and Lastovo. Mljet National Park is rather far from Dubrovnik, the closest urban and tourist centre-roughly 100 minutes by catamaran or 145 minutes by car.

Northern Velebit National Park is the lowest-ranked national park with regard to transport accessibility. The village Krasno $(15 \mathrm{~km}$ from the gate of national park) was selected as the entry point to the national park. It is connected by county roads $\check{Z}_{5126}$ and $\check{Z}_{5140}$, which have a lower quality and safety level in relation to state roads. Public transport to the park does not exist. Otočac, the closest urban centre, is located at a bit more than 30 
minutes away by car, and the leading tourist centre (Crikvenica) is $75 \mathrm{~min}$ utes away by car.

Regarding nature parks, the highest score was achieved by Kopački Rit Nature Park. The settlement of Kopačevo was selected as the entrance to the Park. The Park is connected to Osijek, the closest urban and also tourist centre, by county road $\check{Z}_{4056}$. The Park is roughly 15 minutes from Osijek by car, and is connected by public transport with 7 daily bus departures.

Vransko Lake Nature Park and its entrance Prosika are located in the immediate vicinity of the state road D8 (less than $1 \mathrm{~km}$ away) and it is well-connected by public transport, which increases its total score of transport accessibility. Its transport accessibility score is also increased by the relative vicinity of the town Vodice, an urban and leading tourist centre, which is located at about 20 minutes away by car.

The entrance to Medvednica Nature Park is its highest summit (Sljeme), because the highest zone of Medvednica is also the most visited area of this nature park. It is connected by county roads Ž1048 and Ž1049 with the closest urban and tourist centre-Zagreb- and is roughly 20 minutes away by car. It is also connected to Zagreb by eight daily bus departures. At the time of writing, a cable car to the summit Sljeme is being built, which will further increase its public transport accessibility.

Telašćica Nature Park is a unique protected area, because it is located on the island Dugi Otok. The island settlement Sali $(1.5 \mathrm{~km}$ from the gate of the Park) was selected as the entrance to the nature park. State road D1o9 runs along the entire island. There are no public buses, but there is public sea transport. Sali is connected to Zadar, as an urban and leading tourist centre, via a 45-minute ferry ride that runs four times daily.

Lastovo Islands Nature Park is far from the mainland, which means that it has lower transport accessibility. The island settlement Ubli, the entrance to the Park, is connected by a larger number of ship departures travelling to Vela Luka, Dubrovnik, and Split, as well as eight bus departures passing along the island on the state road D119. However, the transport accessibility score took a significant hit due to temporal distance from an urban centre (Korčula), which is 75 minutes away by ship, as well as from the leading tourist centre (Split) that is over four hours away by ship.

Lonjsko Polje Nature Park holds the same transport accessibility score as Lastovo Islands Nature Park. The difference is in the road category. Namely, Lonjsko Polje is one of two nature parks, along with Biokovo, that 
is connected by a local road (the lowest quality and safety level of road). The entrance to the park is the village Čigoč, which has relatively weak public transport connectivity. The transport accessibility score is improved by the vicinity of an urban centre (Sisak), which is less than 30 minutes away from Čigoč by car, while the leading tourist centre (Zagreb) is slightly less than 90 minutes away by car.

Just as in the case of Medvednica, the summit of the mountain is the entrance to Učka Nature Park. The county road leading to Učka is narrow and winding, so the summit is not connected by public transport. Opatija, which is both the largest urban and leading tourist centre of the immediate area, is located at a less than 45 minutes from the summit of Učka by car.

Papuk Nature Park has an identical transport accessibility score to Učka Nature Park. The entrance to Papuk Nature Park (Jankovac mountain hut, as the most visited site in the park) is not connected by public transport, and personal vehicles access it via county road $\check{Z}_{4253}$. Moreover, Papuk Nature Park is far from the nearest urban centre (Slatina), as well as from the area's leading tourist centre (Osijek). Jankovac mountain hut is slightly less than 45 minutes from Slatina and 95 minutes from Osijek by car.

Biokovo Nature Park had the lowest score of transport accessibility. The summit Sveti Jure (the highest summit of the mountain and one of the most attractive and most visited park localities for tourists) was selected as the entrance to the park, and it can be reached by a narrow and winding local road. Makarska is the closest urban and tourist centre and is roughly 65 minutes away by car. There are no public transport options available for travelling to Biokovo.

\section{The connection between transport accessibility and tourist}

\section{flow in protected areas}

Although the amount of visitors to Croatian national parks and nature parks is increasing every year, there is an evident and pronounced difference in visits to national parks compared to nature parks. Furthermore, great differences in the number of visitors can be observed if protected areas are compared individually (Tab. 3, Tab. 4$)^{4}$.

4 The tables show the official data from the Ministry of Environment and Energy of the Republic of Croatia related to the estimated number of visitors-not of the total number of entrance tickets sold. 
Tab. 3 Number of visitors to Croatian national parks from 2013 to 2018

\begin{tabular}{lcccccc}
\hline \multirow{2}{*}{ National Park } & \multicolumn{7}{c}{ Year } \\
\cline { 2 - 7 } Plitvice Lakes & 2013 & 2014 & 2015 & 2016 & 2017 & 2018 \\
\hline Krka & $1,188,798$ & $1,184,449$ & $1,357,304$ & $1,429,228$ & $1,720,331$ & $1,796,670$ \\
\hline Kornati & 786,635 & 804,411 & 951,106 & $1,071,561$ & $1,284,720$ & $1,354,802$ \\
\hline Brijuni & 94,257 & 105,000 & 157,574 & 220,057 & 229,061 & 237,435 \\
\hline Mljet & 151,007 & 153,086 & 160,010 & 181,560 & 169,299 & 171,794 \\
\hline Paklenica & 120,464 & 100,787 & 112,156 & 126,699 & 140,329 & 145,751 \\
\hline Northern Velebit & 114,381 & 122,189 & 119,686 & 127,848 & 140,561 & 144,624 \\
\hline Risnjak & 15,777 & 14,360 & 16,471 & 20,299 & 22,919 & 30,638 \\
\hline \multicolumn{1}{c}{ Total } & 13,725 & 11,338 & 12,715 & 14,346 & 16,575 & 16,816 \\
\hline
\end{tabular}

Source: Ministry of Environment and Energy of the Republic of Croatia, Zagreb, 2019

Tab. 4 Number of visitors to Croatian nature parks from 2013 to 2018

\begin{tabular}{lcccccc} 
& \multicolumn{7}{c}{ Year } \\
\cline { 2 - 7 } Nature park & 2013 & 2014 & 2015 & 2016 & 2017 & 2018 \\
\cline { 2 - 7 } Telašćica & 121,746 & 114,413 & 113,295 & 116,378 & 123,327 & 124,841 \\
\hline Vransko Lake & 10,938 & 13,449 & unknown & 24,385 & 114,598 & 122,256 \\
\hline Biokovo & 44,059 & 46,378 & 46,982 & 54,820 & 64,130 & 64,484 \\
\hline Velebit & 35,317 & 32,030 & 37,202 & 43,091 & 49,889 & 56,319 \\
\hline Žumberak-Sa- & 2,800 & 1,652 & 52,600 & 44,254 & 41,674 & 43,179 \\
moborsko Gorje & 26,013 & 26,764 & 29,836 & 38,679 & 37,062 & 40,135 \\
\hline Kopački Rit & 29,792 & 21,209 & unknown & 17,000 & 24,520 & 29,567 \\
\hline Lastovo Islands & 20,560 & 26,191 & 29,873 & 32,591 & 34,423 & 20,081 \\
\hline Medvednica & 2,346 & 1,687 & unknown & 30,000 & 30,000 & 20,000 \\
\hline Učka & 11,850 & 12,320 & 12,100 & 16,500 & 17,000 & 17,500 \\
\hline Lonjsko Polje & 6,636 & 5,741 & 4,333 & 5,685 & 7,470 & 7,171 \\
\hline Papuk & 312,057 & 301,834 & 326,221 & 423,383 & 544,093 & 545,533 \\
\hline Total & & & & & & \\
\hline
\end{tabular}

Source: Ministry of Environment and Energy of the Republic of Croatia, Zagreb, 2019

The number of visitors to national parks was seven times higher in 2018 than the number of visitors to nature parks. It is worth emphasising here, however, that the official number of visitors is not wholly accurate. Namely, certain nature parks have a significantly higher number of visitors compared to official data. The absence of an entrance fee in nature parks is the main reason for this; entrance fees are only charged for some individual sights or activities within nature parks. Therefore, the actual number 
of visitors to nature parks located near large cities with high recreational demand (e.g. Medvednica, Žumberak-Samoborsko Gorje, Učka) is significantly higher than official data. It can be assumed that the aforementioned nature parks have a higher number of visitors than most national parks.

For the most visited parks-Plitvice Lakes and Krka-there were three, i.e. two and a half times more visitors than all visits to the rest of the national parks combined, confirming the significantly higher general tourist attractiveness of national parks than of nature parks.

Plitvice Lakes is the most visited national park in Croatia, because it is the only Croatian protected area included in the UNESCO World Nature Heritage list. In other words, this status provides the Park a greater level of attraction than other Croatian national and nature parks, because it guarantees a certain sensation or "wow-effect" to visitors, i.e. promising to be a memorable tourism experience (Opačić, 2019). Due to the aforementioned, as well to the accommodation capacity in and around the protected area, it should be observed as a tourism destination in and of itself and pillar of tourism development of the wider area (Lika, Kordun).

Among other national parks, Krka National Park stands out in visitor numbers. Its high number of visits is due to the Park's exceptional level attractiveness to tourists, high transport accessibility due to the nearby town (Skradin) and strong coastal tourist centre (Šibenik), as well as its motorway connection to other leading tourism destinations along the Adriatic coast. Other national parks that stand out in number of visitors (Kornati, Brijuni, Mljet, and Paklenica) are also situated on the Croatian Littoral, which is the leading tourism area of Croatia.

In contrast to the aforementioned parks, Northern Velebit and Risnjak national parks, despite their level of ecological preservation and tourist attractiveness, are significantly less visited. Both of these national parks encompass some of the most well-preserved mountainous areas of Croatia, and they have lower transport accessibility than most of the national parks located on the coast and islands. A significant reason for lower visitor numbers is also the fact that the most attractive sights of the Northern Velebit and Risnjak national parks (certain summits of Velebit, Premužić Trail, Veliki Risnjak Peak, the source of the Kupa River) are inaccessible by car, thus demanding more time and effort in order to visit them.

The most prominent nature parks in terms of visitor numbers are definitively Telašćica and Vransko Lake. The reason for this is their geographical position on the Croatian Littoral, the leading tourism area in the 
country, in the immediate vicinity of strong coastal tourism destinations (Zadar, Biograd na Moru, Vodice, Šibenik). An additional reason for high visitor numbers in Telašćica is also the vicinity of Kornati National Park, with which it has a certain landscape unity, so it is also visited by many visitors who visit Kornati. Velebit and Biokovo nature parks encompass large mountains rising steeply above the coast, where strong coastal tourism destinations have developed (e.g. Crikvenica-Vinodol Littoral, Makarska Littoral). An important reason for the high number of visitors to Biokovo Nature Park compared to other nature parks also lies in direct road transport access to the most attractive sights (Sveti Jure and Vošac summits).

The island Lastovo is the central area of Lastovo Islands Nature Park, and it shows far lower visitor numbers due to its weak transport connectivity. An additional reason for low visitor numbers may also be the modest promotion of the Park on the tourism market. It is noteworthy that this is the youngest Croatian nature park, founded in 2006, so a stronger dependence on the status of protected area for tourism development can be expected in the future. Among other nature parks, only Kopački Rit is generally considered to be a must-see tourist sight during a tour of Baranja, a region that has had successful development of rural tourism of late, and of the nearby urban and tourist centre Osijek.

Žumberak-Samoborsko Gorje, Medvednica, Učka, Lonjsko Polje, and Papuk nature parks encompass mountainous or marsh/flood plain areas visited mostly by day-trippers (recreationists) from nearby urban centres (e.g. Zagreb, Rijeka, Sisak, Osijek), rather than tourists, which is the main reason for their low visitor numbers. An equally significant reason is also the fact that in these nature parks, specific locales are not prominent enough in terms of attractiveness to become independent tourist attractions in their own right. Rather, the fundamental phenomena due to which these areas were protected are dispersed throughout a wider area, making it difficult to valorise them in terms of tourism.

When interpreting data on visits to protected areas, especially nature parks, it is necessary to take into account that they show the estimated number of visitors and not the number of entrance tickets sold, which indicates discrepancies in relation to the actual numbers of visitors. As there is no entry fee for nature parks (only for specific locales or attractions therein), it is clear that the number of visitors in this category of protected areas is harder to estimate than in national parks, where entrance fees are charged. Therefore, it is realistic to expect discrepancies between the offi- 
cial statistical data of the Ministry of Environment and Energy regarding the number of visitors, and the actual number of visitors.

In order to determine the extent to which transport accessibility for entrances to the 16 Croatian national parks and nature parks is related to the number of visitors, the method of correlation analysis was used, whereby the transport accessibility scores for entrances to protected areas were taken as the independent variable, and the number of visitors as the dependent variable.

On the level of all protected areas included in the analysis, a strong correlation between the transport accessibility score of a protected area and the number of visitors in $2018(\mathrm{~N}=16 ; \mathrm{r}=0.536)$ was determined, whereby the more transport-accessible Croatian national parks and nature parks were those with higher numbers of visitors, i.e. higher tourist flow (Fig. 2).

A high value of Pearson coefficient is weighted mainly by national parks, recording an even higher correlation among the variables, as opposed to nature parks, where a correlation between transport accessibility and the number of visitors in 2018 was not determined. Therefore, an even stronger correlation between the transport accessibility score and the number of visitors in $2018(\mathrm{~N}=7 ; \mathrm{r}=0.706)$ is shown for national parks, whereby the more transport-accessible national parks show higher visitor numbers. It is noteworthy that the number of national parks in the correlation analysis is low, so these results can be taken into consideration only as illustrative (Fig. 3).

A higher level of correlation between the transport accessibility score and the number of visitors in national parks can be explained with the fact that national parks, in the context of the number of visitors (tourist visits), can be identified with tourist sights (some even with tourism destinations). It could be recognised that better quality of their transport accessibility is in line with their higher tourist flow. Namely, national parks are generally more attractive to tourists than nature parks, due to their higher level of protection and preservation of nature. Therefore, considering the significance of transport accessibility, they showcase features similar to other tourist sights/destinations. Furthermore, national parks undoubtedly keep more accurate records of the number of visitors, because all visitors are required to pay an entrance fee during their visit.

Nature parks show lower levels of correlation between their transport accessibility score and the number of visitors $(\mathrm{N}=9 ; \mathrm{r}=0.355)$, leading to the conclusion that the more transport-accessible Croatian nature parks are of- 


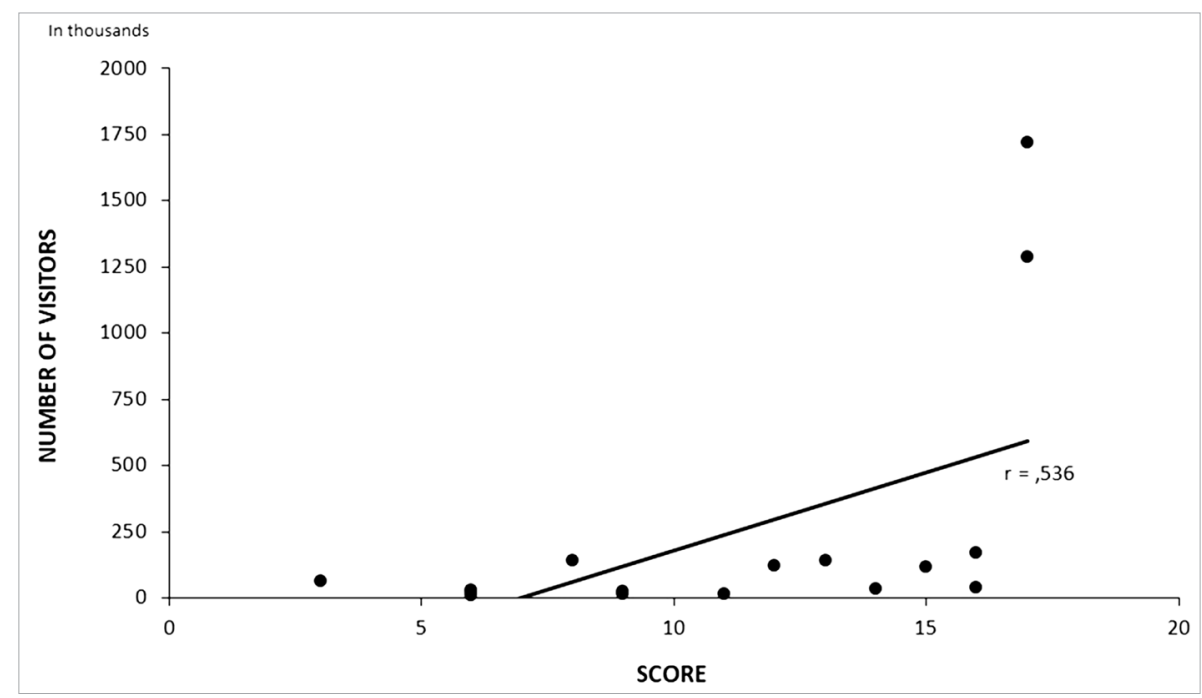

Fig. 2 Scatter plot of the transport accessibility score of the protected area (x) and the number of visitors in 2018 (y) in Croatian national parks and nature parks Source: authors, according to data from the Ministry of Environment and Energy of the Republic of Croatia, 2019

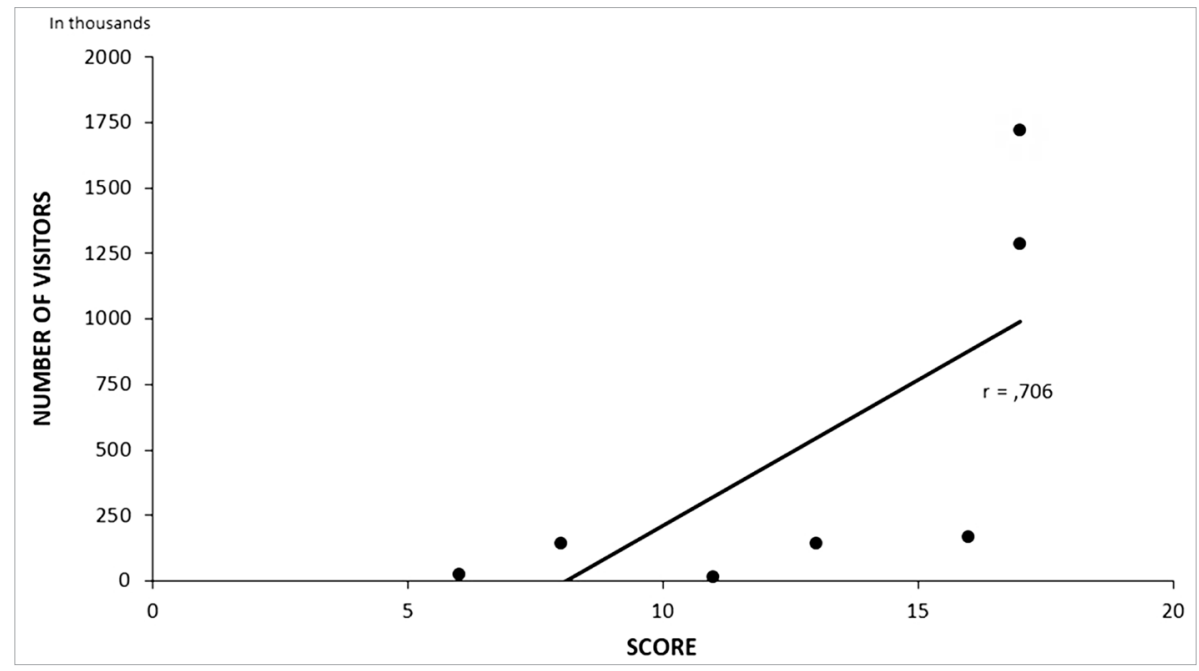

Fig. 3 Scatter plot of the transport accessibility score of the protected area (x) and the number of visitors in 2018 (y) in Croatian national parks Source: authors, according to data by the Ministry of Environment and Energy of the Republic of Croatia, 2019 
ten not the most visited. As with national parks, it is necessary to emphasise the small number of nature parks in the sample, so the results of the correlation analysis should only be taken into consideration as illustrative (Fig. 4).

A significantly weaker correlation between the transport accessibility score and the number of visitors in nature parks leads to the conclusion that these protected areas, in terms of visitor numbers (tourist visits), are less attractive to tourists. They are also less prominent in marketing campaigns on the tourism market, so the number of visitors to nature parks does not depend on the quality of transport accessibility to the same extent as it does in national parks. The exceptions to this are nature parks with a large number of visitors, located in the vicinity of leading coastal tourism destinations, as well as those featuring highly attractive tourist sights (e.g. escarpments in Telašćica Nature Park and the summits Sveti Jure and Vošac in Biokovo Nature Park that offer views of the Dalmatian islands and Dalmatinska Zagora). In the observed context, these nature parks "behave" like national parks, i.e. like tourist sights/destinations in and of themselves. Moreover, the estimation of the number of visitors to nature parks is less accurate in comparison to national parks, because there is no entrance fee

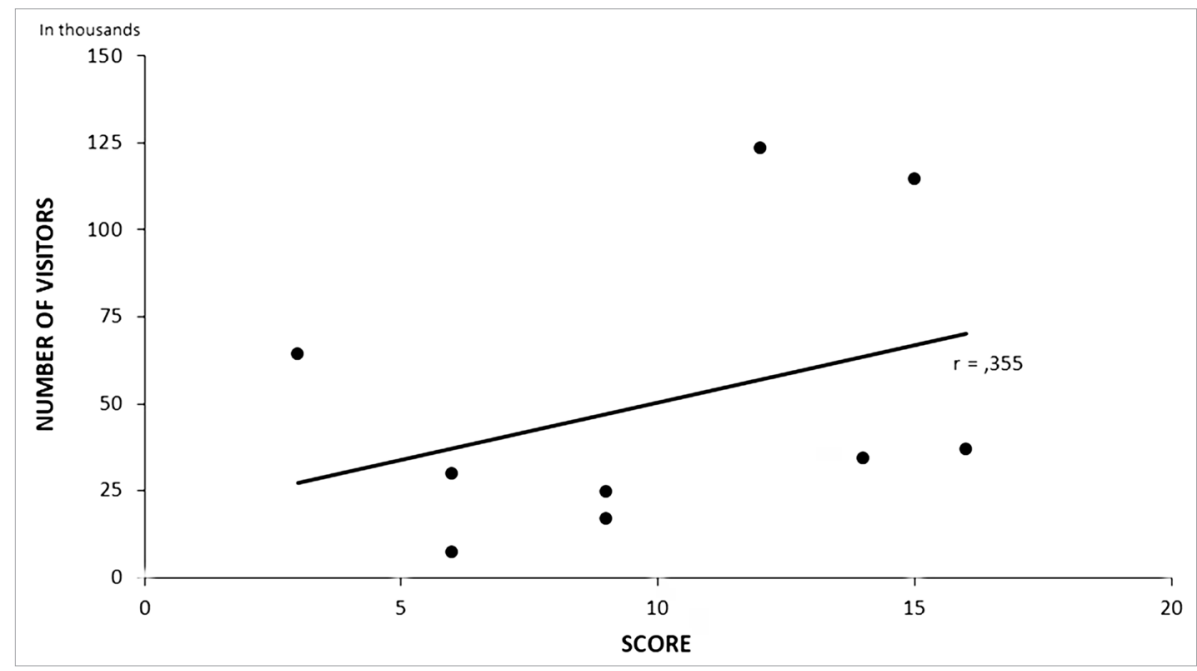

Fig. 4 Scatter plot of the transport accessibility score of the protected area $(\mathrm{x})$ and the number of visitors in 2018 (y) in Croatian nature parks Source: authors, according to data by the Ministry of Environment and Energy of the Republic of Croatia, 2019 
to the nature park itself, only to specific sights or specific activities/programmes within the protected area; therefore, these findings should be taken into consideration with reserve.

\section{Conclusion}

Transport is one of the significant preconditions and factors of tourist flow in all types of tourist areas. The role of transport in protected areas as a tourist factor is especially pronounced, because transport is simultaneously a prerequisite for a large number of tourist visits, but it is also a limiting factor due to potentially adverse environmental circumstances.

The aim of this chapter was to assess transport accessibility as a factor of tourist flow in Croatian national parks and nature parks. The research observed 16 of the 19 Croatian national parks and nature parks, in which it was possible to determine entrances used by the majority of visitors during their visit. The 16 locations selected in this way underwent scoring assessment using a point scale to determine transport accessibility, according to the following factors:

a) public transport connectivity (bus, ship/catamaran/ferry);

b) public transport frequency;

c) road connectivity;

d) time distance from city/town; and

e) time distance from a leading tourist centre.

In order to determine the connection between transport accessibility and tourist flow, a correlation analysis was conducted for each national park and nature park in 2018, with the transport accessibility score as the independent variable and the number of visitors as the dependent variable.

The research showed that the national parks and nature parks with better transport accessibility also have higher visitor numbers. This conclusion rises from the strong correlation between transport accessibility and tourist flow in national parks, whereas in nature parks the correlation between these variables is weaker. The latter can be explained with the fact that national parks are more attractive in a tourism context and are more exposed via marketing campaigns in the tourism supply than nature parks, therefore, they attract a larger number of (foreign) tourists. Those national parks that feature accommodation capacities within their borders, e.g. Plitvice Lakes, Brijuni, Mljet, can be identified as tourism destinations in and of themselves and are frequently presented as such on the tourism mar- 
ket. Therefore, within the context of tourism valorisation, the majority of Croatian national parks are recognised as tourist sights belonging to larger tourism destinations (tourism regions).

Most nature parks located in the vicinity of leading Croatian coastal tourism destinations (e.g. Telašćica, Vransko Lake, Biokovo) "behave" in a similar way to national parks on the tourism market, so it could be presumed that tourists prevail in the structure of their visitors. On the other hand, certain nature parks with recreational attractiveness and facilities (e.g. Medvednica, Žumberak-Samoborsko Gorje, Učka), are predominantly visited by day-trippers from urban centres nearby, whereby a significant motive for the visit is recreation.

The chapter represents a contribution to research of the connection between transport and tourism in protected areas, and it should serve as a starting point for future, more comprehensive research studies aimed at enhancing the quality of the implementation of sustainable development principles in the management of protected areas. Thereby, it is especially important to place emphasis on improving the spatial orientation of visitor flows in protected areas, in order to maintain protection of nature as a primary and fundamental goal, while simultaneously developing sustainable tourism and recreation.

\section{References}

Ament, R., Clevenger, A. P., Yu, O., Hardy, A., 2008: An assessment of road impacts on wildlife populations in U.S. National Parks, Environmental Management 42 (3), 480-496, DOI: 10.1007/soo267-008-9112-8.

Bralić, I., 200o: Turizam i nacionalni parkovi u Hrvatskoj, Turizam 48 (4), 373-378.

Casas, I., Horner, M. W., Weber, J., 2009: A comparison of three methods for identifying transport-based exclusion: a case study of children's access to urban opportunities in Erie and Niagara Counties, New York, International Journal of Sustainable Transportation 3 (4), 227-245, DOI: 10.1080/15568310802158761.

Collum, K. K., Daigle, J. J., 2015: The shift from automobiles to alternatives and the role of intelligent transport systems, in: Sustainable Transportation in Natural and Protected Areas (ed. Orsi, F.), Routledge, London - New York, 57-69. 
Cullinane, S., 1997: Traffic management in Britain's national parks, Transport Reviews: A Transnational Transdisciplinary Journal 17 (3), 267-279, DOI: 10.1080/01441649708716985.

Cullinane, S., Cullinane, K., 1999: Attitudes towards traffic problems and public transport in the Dartmoor and Lake District National parks, Journal of Transport Geography 7 (1), 79-87, DOI: 10.1016/So966-6923(98)00027-1.

Čavlek, N., Bartoluci, M., Prebežac, D., Kesar, O., 2011: Turizam - ekonomske osnove i organizacijski sustav, Školska knjiga, Zagreb.

Daigle, J. J., 2008: Transportation needs in national parks: a summary and exploration of future trends, The George Wright Forum 25 (1), 57-64.

Daigle, J. J., Zimmermann, C. A., 2004: Alternative transportation and travel information technologies: monitoring parking lot conditions over three summer seasons at Acadia National Park, Journal of Park and Recreation Administration 22 (4), 81-102.

D’Haese, S., De Meester, F., De Bourdeaudhuij, I., Deforche, B., Cardon, G., 2011: Criterion distances and environmental correlates of active commuting to school in children, International Journal of Behavioral Nutrition and Physical Activity 8 (88), 1-10, DOI: 10.1186/1479-5868-8-88.

Dickinson, J., Lumsdon, L., 2010: Slow Travel and Tourism, Earthscan, London - New York.

Eaton, B., Holding, D., 1996: The evaluation of public transport alternatives to the car in British National Parks, Journal of Transport Geography 4 (1), 5565, DOI: 10.1016/0966-6923(95)00037-2.

Fyhri, A., Hjorthol, R., 2009: Children's independent mobility to school, friends and leisure activities, Journal of Transport Geography 17 (5), 377384, DOI: 10.1016/j.jtrangeo.2008.10.010.

Geurs, K. T., Ritsema van Eck, J. R., 2001: Accessibility measures: review and applications, RIVM Report 408505 006, National Institute of Public Health and the Environment, Bilthoven, https://www.researchgate.net/publication/46637359_Accessibility_Measures_Review_and_Applications (16. 03. 2019)

Gosar, A., 2017: Managing sustainable tourism in protected areas, in: Tourism in protected areas of nature in Serbia and Slovenia (eds. Filipović, D. et al.), University of Belgrade - Faculty of Geography, Belgrade, 3-11.

Guiver, J., Davies, N., Weston, R., 2015: Visitor preferences toward scheduled bus use in natural and protected areas, in: Sustainable Transportation in Natural and Protected Areas, Routledge (ed. Orsi, F.), London - New York, 45-56. 
Halden, D., 2011: The use and abuse of accessibility measures in UK passenger transport planning, Research in Transportation Business and Management 2, 12-19, DOI: 10.1016/j.rtbm.2011.05.001.

Halden, D., Jones, P., Wixley, S., 2005: Measuring accessibility as experiences by different socially disadvantaged groups, Working Paper 3: Accessibility Analysis Literature Review, Transport Studies Group, University of Westminster, London, https://pdfs.semanticscholar.org/bf91/f2ab89d40532290e73c5381acdd47c9238e2.pdf? $\mathrm{ga}=2.123485452 .625183411 .1565549820-713115584.1565549820$ (16. 03. 2019.)

Hurni, A., 2006: Transport and social disadvantage in Western Sydney: a partnership research project, University of Western Sydney and Western Sydney Community Forum, Sydney, https://researchdirect.westernsydney.edu.au/islandora/object/uws\%3A23088/datastream/PDF/view (16. 03. 2019.)

Hurni, A., 2007: Marginalised groups in Western Sydney: The experience of sole parents and unemployed young people, in: No Way To Go - Transport and Social Disadvantage in Australian Communities (eds. Currie, G. et al.), Monash University ePress, Clayton, 10.1-10.11, DOI: 10.2104/nwtgo710.

Kaza, N., 2015: Time dependent accessibility, Journal of Urban Management 4 (1), 24-39, DOI: 10.1016/j.jum.2015.06.001.

Kimpel, T., Dueker, K., El-Geneidy, A., 2007: Using GIS to measure the effect of overlapping service areas on passenger boardings at bus stops, Urban and Regional Information Systems Association Journal 19 (1), 5-11.

Klarić, Z., Gatti, P., 2006: Ekoturizam, in: Hrvatski turizam: plavo, bijelo, zeleno (eds. Čorak, S., Mikačić, V.):, Institut za turizam, Zagreb, 149-165.

Kušen, E., 2002: Turistička atrakcijska osnova, Institut za turizam, Zagreb.

Kušen, E., 2010: A system of tourism attractions, Tourism 58 (4), 409-424.

Litman, T., 2007: Evaluating accessibility for transportation planning: measuring people's ability to reach desired goods and activities, Victoria Transport Policy Institute, http://www.vtpi.org/access.pdf (16. 03. 2019.)

Marković, I., 2015: Problemi i mogućnosti održivoga upravljanja zaštićenim prirodnim područjima: primjer Nacionalnog parka Plitvička jezera, PhD Thesis, University of Zagreb, Faculty of Science, Department of Geography, Zagreb.

Marković Vukadin, I., 2017: Sustainability issues in management of tourism in protected areas: case study of Plitvice Lakes National Park, in: Evolution of Destination Planning and Strategy: the Rise of Tourism in 
Croatia (eds. Dwyer, L. et al.), Palgrave Macmillan, Cham, 201-219, DOI: 10.1007/978-3-319-42246-6_10.

Monz, C., D’Antonio, A., Lawson, S., Barber, J., Newman, P., 2016: The ecological implications of visitor transportation in parks and protected areas: examples from research in US National Parks, Journal of Transport Geography 51, 27-35, DOI: 10.1016/j.jtrangeo.2015.11.003.

Murray, A. T., Davis, R., Stimson, R. J., Ferreira, L., 1998: Public transportation access, Transportation research part D: Transport and Environment 3 (5), 319-328, DOI: 10.1016/S1361-9209(98)ooo10-8.

Murray, A. T., Wu, X., 2003: Accessibility tradeoffs in public transit planning, Journal of Geographical Systems 5 (1), 93-107, DOI: 10.1007/s101090300105.

Müller, H., 2004: Turizam i ekologija: povezanost i područja djelovanja, Masmedia, Zagreb.

Newsome, D., Moore, S. A., Dowling, R. K., 2013: Natural Area Tourism: Ecology, Impacts and Management, Channel View Publications, Bristol Buffalo - Toronto.

Opačić, V. T. 2019: Tourism valorisation of cultural heritage, in: Cultural Urban Heritage: Development, Learning and Landscape Strategies (eds. Obad Šćitaroci, M. et al.), The Urban Book Series, Springer Nature, Cham, 181196, DOI: 10.1007/978-3-030-10612-6_15.

Opačić, V. T., Curić, D., Jandras, M., Kutle, K., Marijan, N., Mirt, I., Perković, D., Vodanović, I., 2014: Zaštićena područja kao rekreacijske zone grada primjer Parka prirode Medvednica, Hrvatski geografski glasnik 76 (1), 6187, DOI: 10.21861/HGG.2014.76.01.04.

Opačić, V. T., Lukić, A., Fuerst-Bjeliš, B., 2005: Sustainable development of recreation and tourism in the protected areas of Croatia: issues and indicators, Problemi na geografijata 3-4, 209-223.

Orsi, F., 2015a: Sustainability potentials of various transport modes in natural settings, in: Sustainable Transportation in Natural and Protected Areas (ed. Orsi, F.), Routledge, London - New York, 28-41.

Orsi, F., 2015b: Sustainability requisites of transportation in natural and protected areas, in: Sustainable Transportation in Natural and Protected Areas (ed. Orsi, F.), Routledge, London - New York, 11-27.

Plummer, R., 2009: Outdoor recreation: an introduction, Routledge, London New York.

Prideaux, B., 2000: The role of the transport system in destination development, Tourism Management 21 (1), 53-63, DOI: 10.1016/So261-5177(99)ooo79-5. 
Weston, R., Davies, N., Guiver, J., 2015: Cycle tourism development in parks: the experience of the Peak District National Park (UK), in: Sustainable Transportation in Natural and Protected Areas (ed. Orsi, F.), Routledge, London - New York, 140-149.

Williams, S., 2003: Tourism and recreation, Prentice Hall, Harlow.

\section{Sources}

Croatian Bureau of Statistics, 2019: Tourism, 2018, Statistical Reports 1639, Zagreb.

Google Maps, 2019: Map data (C2019.

Ministry of Environment and Energy of the Republic of Croatia, 2017: Nature Protection Database, Croatian Agency for the Environment and Nature, Zagreb.

Ministry of Environment and Energy of the Republic of Croatia, 2019: Internal Data, Zagreb. 


\title{
Chapter 3
}

Rural tourism in the surroundings of Krka National Park: factors of development and spatial impacts

\author{
Petra Radeljak Kaufmann
}

\section{Abstract}

This chapter focuses on the development of rural tourism in the area surrounding Krka National Park, situated in northern Dalmatia. Via various functions, especially tourism and recreation, protected areas can influence local development. Since the 1960 , settlements in the surroundings of Krka National Park have faced challenges related to depopulation and socio-economic development. The goal of this chapter is to analyse factors of recent intense development of rural tourism, its spatial impacts in the immediate vicinity of the Park, and various potentials for further development. These trends should be looked at in the framework of tourism development of the Park itself, as well as tourism development trends in the interior of Dalmatia. A case study of the Town of Drniš was conducted to closely examine recent trends and the potential for development of rural tourism in the near future.

Key words: rural tourism, protected areas, geography, Krka National Park, Drniš, Dalmatia, Croatia 


\section{Introduction}

National parks are defined by the Nature Protection Act (Official Gazette $80 / 13,15 / 18,14 / 19)$ as a predominantly unaltered area of exceptional and varied natural values encompassing one or more ecosystems. This category of protected area is primarily intended to protect nature and landscapes and to serve scientific, cultural, educational, and recreational purposes. Tourism and recreation are also present in national parks, in so far as they do not endanger the natural environment. According to Hall and Boyd (2005), tourism that develops in relation to conserving or protecting natural areas (ecotourism, national parks) is a form of nature-based tourism, which also includes tourism in natural settings (such as adventure tourism) and tourism focusing on certain elements of the natural environment (such as safari and wildlife tourism, nature tourism, and marine tourism). It is largely via tourism and visitor management systems that protected areas influence local development in the areas that surround them.

Krka National Park is situated in the northern part of the Croatian coastal region of Dalmatia. It was proclaimed in 1985, protecting the Krka River and its waterfalls, as well as the lower course of the Čikola River (the Park's southwestern and northern boundaries were revised in 1997). It has seen a steep increase in the number of visitors in recent decades, reaching 1.4 million in 2018.

The Park partially includes the territories of seven local self-government units: the City of Šibenik; the towns of Knin, Drniš, and Skradin; and the municipalities of Ervenik, Kistanje, and Promina ${ }^{1}$ (Fig. 1). Since the 1960 s, the settlements near the Park have often been characterised by depopulation and problems with socio-economic development (See: Bjelajac, 2008). Previous research demonstrated that, despite intense growth in tourist volume, the Park exercised almost no influence on the stabilisation of settlement patterns in this depopulated zone. However, some socio-economic impacts were recognised, especially in the areas closest to main tourist points of the Park and along main routes leading to the Park's entrances (Radeljak and Pejnović, 2008). One of the important trends in the last decade has been the development of rural tourism in the wider area.

1 In total, Šibenik-Knin County consists of 20 local self-government units. These include the municipalities of Bilice, Biskupija, Civljane, Ervenik, Kijevo, Kistanje, Murter-Kornati, Pirovac, Primošten, Promina, Rogoznica, Ružić, Tisno, Tribunj, and Unešić, as well as towns/cities of Drniš, Knin, Skradin, Šibenik, and Vodice. 


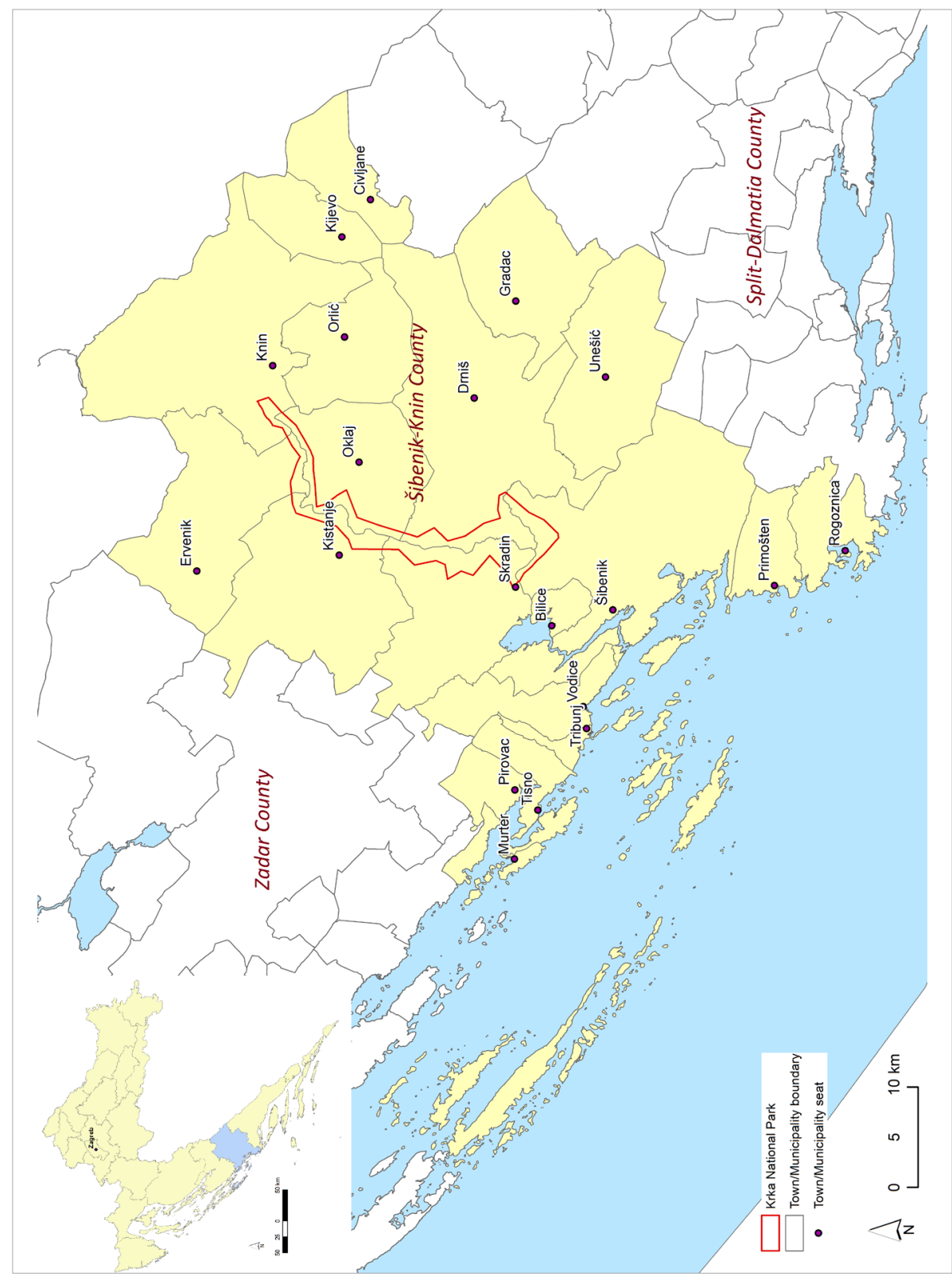

Fig. I Local government units (towns and municipalities) in Šibenik-Knin County in relation to Krka National Park ${ }^{2}$

2 The source for administrative borders was the Central Registry of Spatial Units (CGA, 2013). 
The goal of this chapter is to discern factors contributing to the aforementioned trends and the impacts of such developments. Therefore, statistical indicators were analysed to show the development of the visitation system in Krka National Park, as well as changes in the number of tourist arrivals and overnight stays in the general vicinity of the Park. In order to fully explore how the development of tourism relates to local development, a case study of the Town of Drniš was conducted. Data collection was based on interviews and conversations. Four interviews with local actors-representatives of the Town of Drniš administration, the local tourist board, family agricultural holdings that offer tourism-related services, and Krka National Park-were conducted in August and October 2019. Additionally, three interviews conducted in October 2015 within the scope of the CRORURIS ${ }^{3}$ project, with the Town mayor, a representative of the Local Action Group, and an entrepreneur were used to provide an overview of the general development context and compare development trends. The interviews lasted between 30 and 90 minutes.

The structure of the chapter is as follows. First, several points related to the development of rural tourism, especially in the context of protected areas, are presented. Second, protection, recreation and tourism development in Krka National Park are analysed, together with the trends visible in the surrounding areas. Finally, factors of development and impacts of rural tourism are explored in the case of the Town of Drniš, as one of the local government units participating in the territory of the Park.

\section{Protected areas and rural tourism}

Preservation and protection without serious consideration regarding the area immediately beyond the boundaries of a given protected area were the basic elements of the concept of protected areas until the middle of the $2 \mathrm{O}^{\text {th }}$ century. By the end of the same century, the paradigm had come to include an integrated approach in protected area policy, incorporating protected areas as well as their surroundings. This approach attempts to satisfy the interests of protection and use, seeing (especially) larger protected areas as tools of sustainable regional development (Mose and Weixlbaumer, 2007), which can provide impulses for tourism development, marketing of

3 The research project CRORURIS (2014-2017) developed a set of alternative future scenarios for Croatian rural areas in 2030 (See: Lukić and Radeljak Kaufmann, 2017). 
regional products, and for the development of innovative regional products and services (Hammer, 2007).

Once an activity which focused on viewing the landscape, or pursuing entertainment such as hunting or fishing (Butler, 2011), rural tourism has come to encompass different activities and forms of tourism related to natural and cultural resources in rural areas (Demonja and Ružić, 2010). It should be noted that the specific activities that are engaged in during leisure, recreation, or tourism, are in many cases identical, and key differences can be found in the location, duration, or possibly attitudes, motivations, and perceptions of the participants. The differences between recreation and tourism in particular have become less significant and it is often difficult to determine whether participation in an activity is of a recreational or touristic nature (Butler et al., 1998). For instance, there may be no difference in location or activity between "rural tourism" and "countryside recreation". Many rural tourists and recreationalists are excursionists, i.e. day-trippers, as opposed to those who stay overnight (Hall et al., 2003).

Rural tourism is diverse and exactly how it is understood varies among countries (e.g. Hall et al., 2003). In general, it is based in a rural environment, including a predominantly natural environment, a village, or a smaller town, with expressed forms of traditional agriculture or outstanding natural values. It is connected with local community, traditional culture and products, and should be seen in the context of multi-functional activities in a rural area. Apart from farm tourism, it includes other forms of tourism in a rural area, such as residential tourism, sports and recreational tourism, cultural tourism, religious tourism, adventure tourism, camping tourism, health tourism, nautical tourism, fishing tourism, and gastronomic tourism (Demonja and Ružić, 2010).

Activities undertaken in rural areas are increasing and diversifying, and significantly affecting environmental, economic, and social change. This has attracted attention from policy makers at different levels, indicating the need for adequate planning and management (Hall et al., 2003). Rural tourism is credited with having economic and non-economic effects (Demonja and Ružić, 2010). Its contribution to rural development can include revitalising local economies and improving the quality of life, offering supplementary income for farming, crafts, and services, providing opportunities to re-evaluate heritage and identity, maintaining and renovating buildings and infrastructure, and even influencing demographic process- 
es such as migration (Hall and Jenkins, 1998; Hall et al., 2003; Demonja and Ružić, 2010).

According to Petrić (2008), tourism in protected areas likewise brings potential benefits, such as employment possibilities for the local population, increased income, stimulation and diversification of the local economy, encouraged local production, contributions to natural and cultural heritage protection, and support for research and education of visitors and the local population. There are also potential costs of tourism in protected areas, where tourism and recreation put the primary objective of protecting the natural and cultural phenomena in danger. Apart from those of an environmental nature (environment degradation, loss of biodiversity), there are potential costs of a financial, economic (personnel, infrastructure), and socio-cultural (various conflicts between tourists and tourism development goals, and the local population) nature (Petrić, 2008).

Ultimately, as a tool in local development, tourism should be used in a combination of strategies. Tourism and recreation are not appropriate tools for all rural areas, and not all areas are suited for tourism and/or recreation. Tourism should not take priority over other traditional activities and should be complementary to other uses of local resources (Hall et al., 2003; Boyd and Hall, 2005).

\section{Krka National Park: protection and tourism development}

The Park was officially designated in 1985 , encompassing an area of $142 \mathrm{~km}^{2}$, as a result of continuing efforts to protect the Krka River for its outstanding natural values. Its boundaries were revised in 1997, when its southwestern part (including the town Skradin) was excluded from the Park territory, while its northern boundaries were extended upstream towards the town Knin. Today, Krka National Park covers $109 \mathrm{~km}^{2}$ of the area along the Krka River and the lower course of the Čikola River. The Park's main attractive features are the travertine waterfalls of the Krka River, but it abounds with various hydrological, geomorphological, and biological values, as well as cultural and historical heritage (from archaeological sites, medieval fortresses, and monasteries to old hydroelectric plants), bearing witness to centuries of coexistence of man and river.

Even before the national park was established, Krka's waterfalls and cultural heritage sites attracted numerous visitors. The Park's designation led to the development of a more elaborate visitor management system. Apart from visits from the local population, a key element in visitation of 
Krka National Park since the beginning has been its location near the touristically-developed Adriatic coastline, making it easy for many tourists to come to the Park for day trips. The peak number of visitors in the early stage of Park visitation was reached in $1988(385,837)$. In this period, the Park had 20 permanent and 60 seasonal employees (Knežević-Grubišić, 1997). From 1991 to 1995, during the Croatian War of Independence ${ }^{4}$, many parts of the Park sustained damage and all visitation stopped.

Tourism and recreation in the Park slowly recovered after the War, and the 1988 maximum of visitors was surpassed in 2001 (451,314 visitors). Apart from the impacts of the global economic recession (starting in 2008), which affected the total number of tourists in Croatia, the number of visitors to the Park has been continually increasing, exceeding one million for the first time in 2016 and continuing on to $1,354,802$ in $2018^{5}$ (Fig. 2). National park visitor surveys conducted in 2013, 2017, and 2018 indicate that the most numerous visitors are 28-49 years old with a high level of education. In addition, most of the surveyed visitors come to the Park with their family and friends. The largest number of surveyed visitors come from European

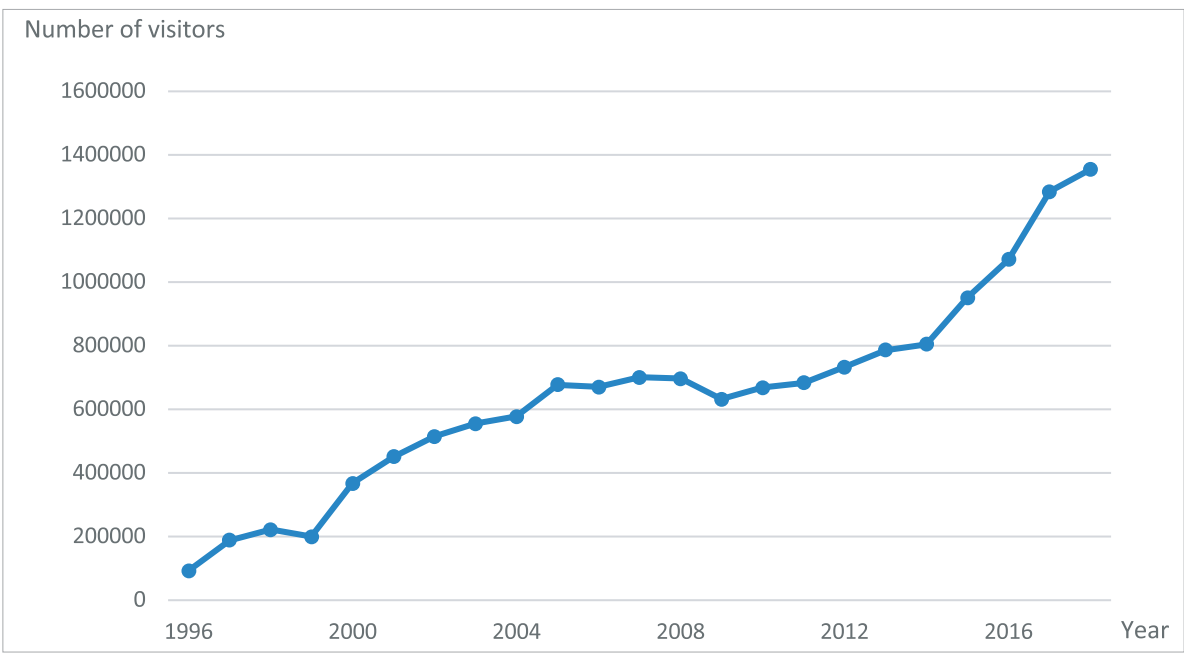

Fig. 2 The number of visitors to Krka National Park 1996-2018

Sources: Krka National Park, 2007; CBS, 2008; CBS, 2009; CBS, 2010; CBS, 2011; CBS, 2012; Krka National Park, 2019

4 Referred to in Croatia as the Homeland War (Domovinski rat).

5 The number of Park visitors does not include members of the local population visiting the Park's churches and monasteries, or engaging in leisure/recreation activities. 
countries-primarily Germany, France, Italy, United Kingdom, Poland, the Netherlands, and Croatia. The main reasons cited by visitors for visiting Krka National Park are: nature/beautiful landscape; rest and relaxation; swimming; photography; richness of flora and fauna; and recreation (Kontić, 2018; Krka National Park, 2018a).

Main characteristics of visitation to Krka National Park are its seasonality and uneven spatial distribution. The average number of visitors in the Park peaks in summer months, primarily July and August (with 315,235 visitors in August on average in the 2014-2018 period), while the number of visitors in winter months is very small $(\sim 1,500$ or less in January and February) (Fig. 3). The Park's principal tourist attraction is Skradinski Buk - the travertine waterfall and its surroundings - which is visited by $97-98 \%$ of the Park's visitors. In 2017, a visitor limitation model was introduced with the decision to restrict the maximum capacity to 10,000 visitors at any given time at Skradinski Buk (Krka National Park, 2018b).

Other important attractions include: Roški Slap, another well-known travertine waterfall and its surrounding zone; the island Visovac with its monastery and church; the Krka Monastery; and the Burnum archaeolog-

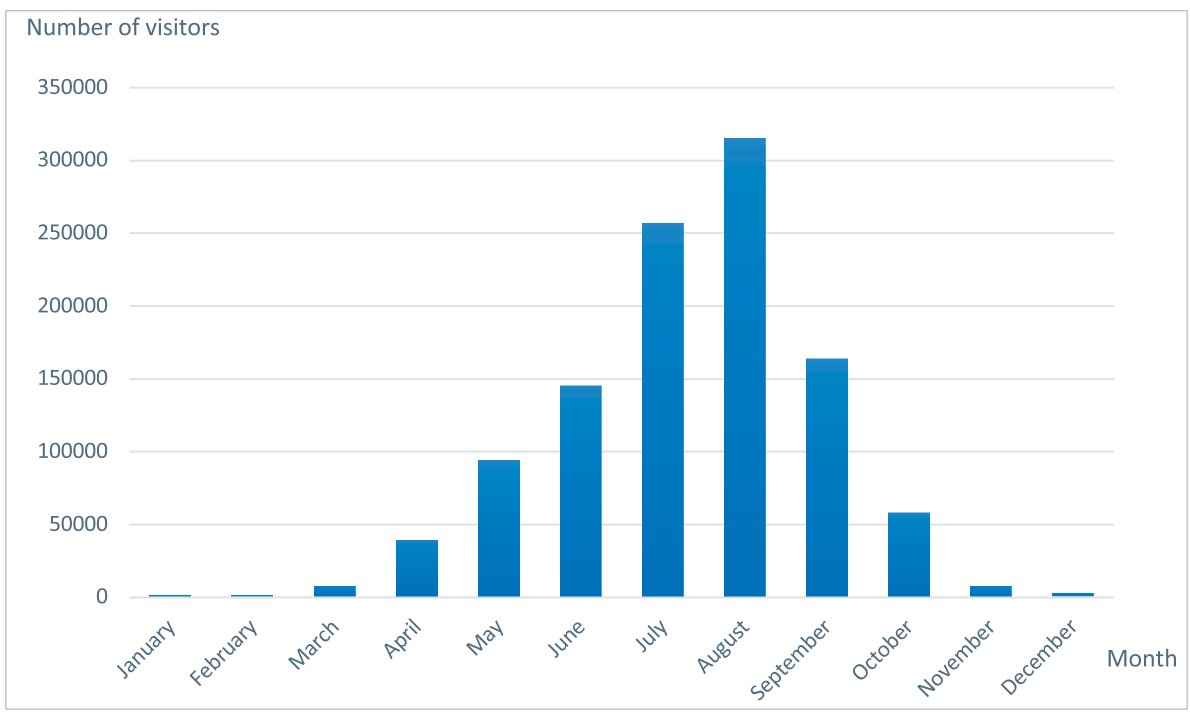

Fig. 3 The average number of visitors to Krka National Park per month in the 2014-2018 period

Source: Krka National Park, 2019 
ical site. The Park's visitation system includes boat excursions, road transportation, walking trails, and bicycle routes. In parallel to the increase in the total number of visitors, the visitation system has been spreading out spatially, i.e. new trails have been opened for visitors and more locales have been made easily accessible.

Apart from trying to achieve a more balanced spatial distribution of visitors $^{6}$, an important goal has been to "activate" the area of the upper course of the Krka River by attracting more visitors to the northern parts of the Park. The Unknown Krka: the hidden treasures of the upper and lower course of the Krka River project ran from 2015 to 2019 and was co-financed by the European Regional Development Fund. It encompassed nature conservation, investments in infrastructure, visitor management, educational and presentation activities, as well as cooperation with the local community, hoping to influence the overall development of the area of the upper and middle course of the Krka River (Krka National Park, n. d.).

Together with the increase in the complexity of Park's functions, and especially with the development of tourism and recreation, the number of Park employees also increased. These jobs are related to the basic administrative functions, protection/preservation, maintenance, promotion of natural and cultural heritage, scientific research, and tourism and visitor management. In 2008 there were 114 permanent and 95 seasonal employees (Pejnović and Radeljak, 2009), and in 2017 there were 214 permanent and 130 seasonal employees (SAO, 2019).

Most of the visitors of Krka National Park who were surveyed in 2013, 2017, and 2018 were staying in private accommodation (30-41\%), followed by hotels $(23-28 \%)$, campsites $(9-10 \%)$, boats $(3-11 \%$; unsurprising given that there is a marina in nearby Skradin), etc. (Kontić, 2018; Krka National Park, 2018a). The number of Park visitors staying in the surrounding area is still relatively small. In general, among the local government units in Šibenik-Knin County, excluding coastal settlements, the largest number of beds, tourist arrivals, and overnight stays is found in the Šibenik, Skradin, and Bilice areas (Tab. 1). All local units, however, saw an increase in the number of tourist arrivals and overnight stays.

6 Most visitors surveyed in either 2013, 2017, or 2018 did not use the opportunity to buy entrance tickets for multiple-day visits (Kontić, 2018; Krka National Park, 2018a). 
Tab. I Indicators of tourism development in local government units in Šibenik-Knin County

\begin{tabular}{|c|c|c|c|c|c|c|}
\hline LGU & $\begin{array}{l}\text { Number } \\
\text { of beds } \\
\text { in } 2018\end{array}$ & $\begin{array}{l}\text { Number } \\
\text { of over- } \\
\text { night stays } \\
\text { in } 2018\end{array}$ & $\begin{array}{l}\text { Number of } \\
\text { tourist arri- } \\
\text { vals in } 2018\end{array}$ & $\begin{array}{c}\text { Avera- } \\
\text { ge number } \\
\text { of overni- } \\
\text { ght stays in } \\
2018\end{array}$ & $\begin{array}{l}\text { Change in } \\
\text { the num- } \\
\text { ber of over- } \\
\text { night stays } \\
2018 / 2016\end{array}$ & $\begin{array}{l}\text { Change in } \\
\text { the num- } \\
\text { ber of tou- } \\
\text { rist arrivals } \\
2018 / 2016\end{array}$ \\
\hline Bilice & 776 & 39132 & 7228 & 5.4 & 160.7 & 181.4 \\
\hline Civljane & 26 & 306 & 58 & 5.3 & 218.6 & 241.7 \\
\hline Drniš & 395 & 18576 & 5306 & 3.5 & 158.2 & 138.2 \\
\hline Kijevo & 26 & 951 & 331 & 2.9 & 598.1 & 233.1 \\
\hline Kistanje & 27 & 258 & 60 & 4.3 & 1612.5 & 3000.0 \\
\hline Knin & 148 & 3868 & 1541 & 2.5 & 121.0 & 111.2 \\
\hline Pirovac & 22 & 782 & 107 & $7 \cdot 3$ & 454.7 & 713.3 \\
\hline Promina & 73 & 4095 & 622 & 6.6 & 137.0 & 215.2 \\
\hline Ružić & 56 & 1477 & 226 & 6.5 & 525.6 & 426.4 \\
\hline Skradin & 932 & 47748 & 22699 & 2.1 & $155 \cdot 3$ & 157.0 \\
\hline Šibenik & 1375 & 79312 & 29801 & 2.7 & 132.6 & 146.3 \\
\hline Tisno & 19 & 1087 & 117 & 9.3 & 135.0 & 128.6 \\
\hline Unešić & 76 & 3114 & 338 & 9.2 & 217.0 & 279.3 \\
\hline Vodice & 56 & 2589 & 315 & 8.2 & 231.4 & 342.4 \\
\hline
\end{tabular}

\section{Source: eVisitor, 2019}

*Note: the whole of the predominantly island and/or coastal municipalities of MurterKornati, Primošten, Rogoznica, and Tribunj were excluded, as well as coastal and island settlements that were part of other LGUs. The municipalities of Biskupija and Ervenik did not have any tourist arrivals recorded for 2018 .

Although these changes can be attributed to the trend of development of the tourism supply to complement the tourist centres along the coast and advancement of different alternative forms of tourism in the hinterland, areas surrounding the Park also benefit from this position. In words of an interviewee from the Park's administration, 'it is like a spine through this whole area which everyone can very easily latch on to and use its attraction to develop their offer'. The interviewee saw the national park as the primary motivation for visitors staying in the area because 'the national park, in essence, subconsciously transmits this message that it is an area of peace and quiet, relaxation, and this is what they need'. The Park has not been directly involved with developing rural tourism, apart from offering entrance tickets at a special fare for tourists staying in registered accommoda- 
tion facilities in the surrounding area, in order to incentivise longer stays. Nonetheless, their intention is to place all visitor centres outside of the Park in nearby local communities. The Park also invests a part of their funds for local community development, and cooperates with stakeholders in developing plans and management strategies.

\section{Factors of development and impacts of rural tourism in the surroundings of Krka National Park: \\ a case study of the Town of Drniš}

The Town of Drniš is a local self-government unit within Šibenik-Knin County, situated in the northern Dalmatian hinterland. It covers an area $^{7}$ of $351.75 \mathrm{~km}^{2}$ consisting of the town Drniš (the main urban centre) and $26 \mathrm{ru}$ ral settlements (Fig. 4). The neighbouring municipalities of Unešić, Ružić, and Promina can be considered a part of the Drniš subregion, as they were part of the area of the former, larger Municipality of Drniš, which existed until 1992.

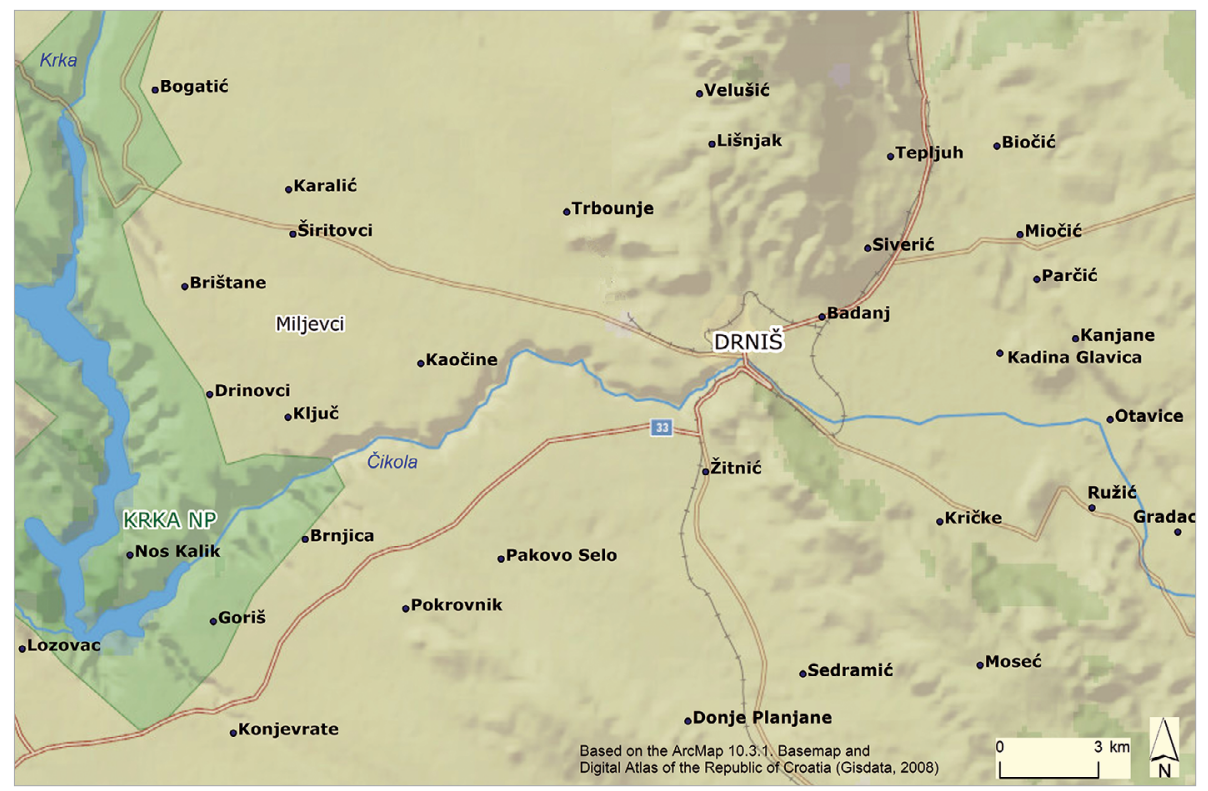

Fig. 4 Geographical position of the Town of Drniš 
The greatest population in the area of the Town of Drniš $(19,538)$ was recorded in $1961^{8}$, followed by a period of intense depopulation, both in Drniš and the wider region of Dalmatinska Zagora. Depopulation was primarily the consequence of strong out-migration towards main urban centres in the coastal zone or the capital (Zagreb), and of an increase in employment abroad. The population of the town Drniš itself, however, grew until 1991, when its peak population $(4,653)$ was recorded; but only a small number of the out-migrating population of surrounding rural settlements settled in Drniš, while the majority moved towards more developed regional centres (Radeljak, 2015). The 1991-1995 Croatian War of Independence was strongly felt in direct and indirect demographic and economic losses. In 2011, the population of the Town of Drniš was 7,498, of which 3,144 lived in the town Drniš (CBS, 2013). Out-migration and emigration have continued in recent years, with a new wave following Croatia's accession to the European Union in 2013. Many rural settlements have been left with a small population, often with an unfavourable age and education structure (Compare: Bjelajac, 2009).

In the 1980s, i.e. the pre-War period, development of Drniš was based on agriculture and the manufacturing industry (e.g. stone processing, textile industry, a large pig farm and prosciutto drying facility, wine production). The war damages and loss of market, combined with issues related to the overall transition in Croatia from a centrally-planned to a market-based economy, followed by the economic crisis starting in 2008 , all resulted in economic decline. The manufacturing industry is still important in the local economy, although it is characterised by a reduced number of businesses with lower production levels and fewer available jobs in relation to the situation in the 1980s. Traditional agricultural products (primarily Drniški pršut-prosciutto from Drniš - cheese, and wine) are another important element. Contemporary Drniš can be characterised as a place with, in words of an actor, 'ideal parameters for living', which should 'promote itself as an ideal town for raising kids', given the general feeling of safety, availability of a kindergarten, primary and secondary school, music school and additional activities, its favourable location, and climate. On the other hand, in places of similar character in Croatia 'a perception is also created among young people that, in reality, there is no perspective, no future', especially related to the availability and diversity of jobs in the area.

8 According to CBS, n. d. 
Development of rural tourism in the Town of Drniš has had a steep increase in recent years. This can be seen from the number of tourist arrivals and overnight stays, which both increased almost 7 times' (Tab. 2). A decade ago, the first few facilities for accommodation were actually family agricultural holdings, offering gastronomic and accommodation services. However, according to an interviewee, that kind of accommodation did not develop further. Development of the typical sort of private accommodation dominated (rooms, apartments, and houses to rent), but without the gastronomic segment (i.e. various types of food service establishments). It should also be stressed that financial incentives have been available for the construction of swimming pools from different levels of government, to help boost the development/adaptation of suitable rural tourism facilities. In general, according to an interviewee's data, the owners of 35 out of $87 \mathrm{fa}$ cilities in the area of Drniš are not local residents-the largest number of those live in Šibenik, although many of them are connected to Drniš by origin.

A good example of rural tourism development is the area of Miljevci, consisting of seven villages (Bogatić, Brištane, Drinovci, Kaočine, Karalić, Ključ, and Širitovci) in close proximity to Krka National Park. According to an interviewee from an agricultural holding involved with tourism, there are around 20 people who rent property in Miljevci, including agricultural holdings, apartments, and/or houses. This interviewee's family has been involved with rural tourism since 2007. They had previous experience working with tourism and hospitality at the seaside and wanted to transfer their experience to their home region. The beginning was difficult because there were hardly any tourists (around 2,00o overnight stays a year in the whole area of Drniš). Gradually, with time, investment, and effort, the numbers increased-in their case, and in the whole area of the Town of Drniš. They were able to improve their rental property and services (e.g. adding a pool, and offering food), which enabled them to increase prices. In the first few years the tourist season went on for 2-2.5 months (July and August) with around 100 overnight stays, but now it starts in the middle of April and lasts until the end of October, amounting to 80o-90o overnight stays in their facility. On average, their guests stay for 2 or 3 days. Most of them come from United Kingdom, Belgium, the Netherlands, France, and Germany.

9 Apart from commercial accommodation, data in Tab. 2 include a small share of non-commercial accommodation. 
Tab. 2 Tourist arrivals and overnight stays in the Town of Drniš between 2010 and 2018

\begin{tabular}{ccccccccc} 
& \multicolumn{4}{c}{ Arrivals } & \multicolumn{5}{c}{ Overnight stays } \\
\cline { 2 - 9 } Year & $\begin{array}{c}\text { Dome- } \\
\text { stic }\end{array}$ & Foreign & Total & $\begin{array}{c}\text { Chain } \\
\text { index }\end{array}$ & $\begin{array}{c}\text { Dome- } \\
\text { stic }\end{array}$ & Foreign & Total & $\begin{array}{c}\text { Chain } \\
\text { index }\end{array}$ \\
\hline 2010 & 450 & 324 & 774 & $/$ & 1653 & 1250 & 2903 & $/$ \\
\hline 2011 & 686 & 815 & 1501 & 193.9 & 1543 & 2503 & 4046 & 139.4 \\
\hline 2012 & 625 & 1116 & 1741 & 116.0 & 2513 & 4147 & 6660 & 164.6 \\
\hline 2013 & 573 & 1513 & 2086 & 119.8 & 1075 & 4397 & 5472 & 82.2 \\
\hline 2014 & 775 & 1742 & 2497 & 119.7 & 2352 & 5487 & 7839 & 143.3 \\
\hline 2015 & 798 & 2395 & 3193 & 127.9 & 1965 & 7091 & 9056 & 115.5 \\
\hline 2016 & 906 & 2942 & 3848 & 120.5 & 2102 & 9887 & 11989 & 132.4 \\
\hline 2017 & 652 & 2992 & 3644 & 94.7 & 2130 & 12659 & 14789 & 123.4 \\
\hline 2018 & 937 & 4391 & 5328 & 146.2 & 2114 & 17064 & 19178 & 129.7 \\
\hline
\end{tabular}

Source: Drniš Tourist Board, 2019

There are several important factors contributing to these trends, starting with the very intense tourism development of the whole country, including the littoral region of Dalmatia, where tourism development has traditionally been concentrated in the coastal zone. Tourism development, however, has also spread to the interior of Dalmatia, with the strengthening of rural tourism. An interviewee pointed out the advantages of the hinterland-peace and quiet, nature, and undisturbed rest, comfortable accommodation, and (usually) lower prices in relation to the coast.

The geographical location of the Town of Drniš is favourable in terms of tourism development; besides being approx. $30 \mathrm{~km}$ away from the touristically-developed coastal zone, its position makes it a suitable base for conveniently visiting different attractions within a two-hour drive, such as Plitvice Lakes National Park, Kornati National Park, Zadar, Šibenik, and Split. The fact that a part of Krka National Park is located in the area of the Town of Drniš is one of the key elements of its position, which was also stressed by interviewees: 'it represents a magnet for visitors'. According to one of the interviewees, the influence of the national park is also visible in the strong development of accommodation facilities, which are promoted over the Internet, stressing their favourable location in relation to Krka National Park. Nevertheless, they 'equally emphasise their proximity to 
Šibenik, their proximity to the sea, and even proximity to other large centres along the coast'.

Local government initiative has also been important in tourism development. This is visible in several EU-funded projects, such as the "Tourism Development in Krka National Park boundary areas" (2014-2016), "Adriatic Canyoning" (2017-2019), and "Natura Drniš" (2017-2019). These projects consisted of activities such as creating bicycle trails, walking paths, and setting up a zip line in the Čikola River canyon. Furthermore, they included the development of marketing and management plans, and the creation of the Centre for Development of Competencies for Rural Tourism in Pakovo Selo-an info centre for those who are involved with or are planning to involve themselves with rural tourism. According to an interviewee from the local government, they would like to motivate visitors of the Park to stay in this area longer, via projects and the development of tourism infrastructure.

Overall, the main tourist activities in the Town of Drniš are diverse. In terms of cultural tourism, the main attraction is the collection of works of the famous Croatian sculptor Ivan Meštrović, who hailed from the area. Active and adventure tourism activities include walking, hiking, cycling, free climbing, canyoning, and riding a zip line. The local gastronomy is also attractive to visitors-local wines, rakija (brandy), olive oil, pršut, and panceta (pancetta). A couple of interviewees stressed the importance of Drniški pršut: '. . . what we have is this pršut as a product making this area recognisable’.

The positive impacts of tourism in the local area, according to interviewees, are visible in infrastructural development, new potentials and opportunities for the local population, improvements in quality of life, and protection of natural and cultural heritage. The area has seen investments in the renovation of old houses, which are then rented out to tourists. Interviewees did not focus on the potentially negative sides to these trends.

What is needed in terms of the local tourism supply is to improve catering services and the selection of restaurants, i.e. diversify and expand the gastronomic supply. Furthermore, better cooperation and networking would be another boost to tourism development, or in words of an actor: 'I think that if everyone would work together, this would go much faster and that there would be much better effects'. It is also important to have good long-term effects of different projects, where different institutions contin- 
ue carrying out planned activities. The full effects of the proximity to Krka National Park in the areas around the upper course of the Krka River are expected in coming years, along with a more spatially balanced visitation system and various activities offered to visitors in the upper course. 'But [Krka] National Park is a national park. In reality, its task is not development of tourism, although in our region it is the main driving force and a large institution, which has both the human capacity and the financial capacity to do ... the largest and most important set of activities'.

Tourist agencies (based in Šibenik and Drniš) have been increasingly including this area in their offers. 'Although the focus is not so much on Drniš, as much as it is a kind of general product hinterland, which then includes, depending on interests, some individual tours which . . maybe do not represent us in the best possible way because we are part of some excursion into the Šibenik-Knin or Split-Dalmatia hinterland, where I am not sure if those visitors . . . have an actual opportunity to experience Drniš .... Agencies could include more of the local tourism supply, which also needs to be more discernible, especially in terms of the gastronomic supply. 'Agencies often look for ... services such as tasting rooms, meaning something fast enough, simple enough, attractive enough, and cheap enough, all in one'.

Plans for the development of rural tourism in the coming years include protecting and promoting cultural heritage, further development of visitor infrastructure, accommodation and gastronomic services, and strengthening the position of Drniš as a centre of rural tourism in this part of the Šibenik-Knin County, to serve as a starting point from which tourists can easily visit various nearby attractions. The general trends in the future will depend on the wider development context and trends coming from the national level, in terms of main economic activities, funds available, and advancement of decentralisation processes. A key factor in this context will be the level of proactivity on the part of the local community, i.e. how well available opportunities will be used, how sustainable the management and use of local heritage will be, and how successfully tourism will be combined with other economic activities. Rural tourism in the Town of Drniš could be a part of an integral development strategy. How far it can go in terms of influencing negative demographic trends and giving a boost to local economy, however, remains to be seen. 


\section{Conclusion}

Protected areas open up possibilities for development of tourism and recreation, not only within their own boundaries, but also in the (predominantly rural) areas that surround them. Rural tourism encompasses different activities, which can affect local economic development, development of infrastructure, social and demographic processes, identities, heritage, and values in a rural area. How sustainable those effects will be depends, for example, on the characteristics of the area, the wider development context, as well as planning and management of tourism activities. With over one million visitors and strong fiscal and management capabilities, Krka National Park has the potential to bring direct and indirect benefits to nearby local communities through employment, education, and cooperation with the local population, and most of all through its visitor management system and tourism development.

The effects of rural tourism development are visible in nearby areas, in connection to the favourable location in relation to the Park, but also as part of a general trend of rural tourism development in the interior of Dalmatia, spreading from the highly touristically-developed coastal zone. The case of rural tourism development in the Town of Drniš, which has seen a rather steep increase in the number of tourist arrivals and stays in recent years, shows the importance of several factors contributing to this trend.

Those factors include its location in close proximity to Krka National Park and the coastal zone, but also accessibility to other important attractions (e.g. Plitvice Lakes National Park, Split, or Zadar) within a two-hour drive, and strong local initiative in a situation where economic diversification is crucial to counteract negative demographic trends. The effects of tourism development are especially visible in infrastructural development, renovation of old houses, and protection and management of natural and cultural heritage. Tourism has created potentials and opportunities for the local population (in combination with local agricultural products, for example).

Keeping in mind the primary function of the Park of protecting its natural and cultural heritage, the full potential of its influence on the local development of the areas in the upper course of the Krka River can be expected in the years to come. This will also depend on how successful the Park's management will be in achieving a more balanced visitor management system. Thereby, it is important to develop the local tourism supply 
further, especially in terms of catering services and restaurants. However, demographic processes are a key issue for the future development, together with strengthening the network of actors and making rural tourism part of an integral development strategy in Dalmatinska Zagora in general.

\section{References}

Bjelajac, S., 2008: Naselja i kretanje stanovništva u porječju Krke, Godišnjak Titius 1 (1), 227-257.

Bjelajac, S., 2009: Strukturalne promjene stanovništva porječja Krke u razdoblju 1991. - 2001., Godišnjak Titius 2 (2), 253-274.

Boyd, S., Hall, C. M., 2005: Nature-based Tourism in Peripheral Areas: Making Peripheral Destinations Competitive, in: Nature-based Tourism in Peripheral Areas: Development or Disaster? (eds. Hall, C. M., Boyd, S.), Channel View Publications, Clevedon - Buffalo - Toronto, 273-280.

Butler, R. W., 2011: Sustainable tourism and the changing rural scene in Europe, in: Sustainable Tourism in Rural Europe, Approaches to development (eds. Macleod, D. V. L., Gillespie, S. A.), Routledge, London - New York, 15-27.

Butler, R, Hall, C. M., Jenkins, J. M., 1998: Introduction, in: Tourism and recreation in rural areas (eds. Butler, R. et al.), Wiley, Chichester, 3-16.

Demonja, D., Ružić, P., 2010: Ruralni turizam u Hrvatskoj, s hrvatskim primjerima dobre prakse i europskim iskustvima, Meridijani, Samobor.

Hall, C. M., Boyd, S., 2005: Nature-based Tourism in Peripheral Areas: Introduction, in: Nature-based Tourism in Peripheral Areas: Development or Disaster? (eds. Hall, C. M., Boyd, S.), Channel View Publications, Clevedon - Buffalo - Toronto, 3-17.

Hall, C. M., Jenkins, J. M., 1998: The policy dimensions of rural tourism and recreation, in: Tourism and recreation in rural areas (eds. Butler, $\mathrm{R}$. et al.), Wiley, Chichester, 19-42.

Hall, D., Mitchell, M., Roberts, L., 2003: Tourism and the Countryside: Dynamic Relationships, in: New Directions in Rural Tourism (eds. Hall, D. et al.), Ashgate, Aldershot, 3-15.

Hammer, T., 2007: Protected Areas and Regional Development: Conflicts and Opportunities, in: Protected Areas and Regional Development in Europe: Towards a New Model for the 21st Century (ed. Mose, I.), Ashgate, Aldershot - Burlington, 21-36.

Knežević-Grubišić, M., 1997: Nacionalni parkovi Krka i Kornati u funkciji razvoja maritimnog turizma, Suvremeni promet 17 (3-4), 285-289. 
Kontić, P., 2018: Istraživanje tržišta i izrada studije praćenja $i$ unapređivanja kvalitete usluga kroz analizu rezultata anketa posjetitelja Nacionalnog parka „Krka“, Nacionalni park „Krka“, Parkovi Hrvatske, Šibenik, http:// www.npkrka.hr/upload/stranice/2018/03/2018-03-01/205/usporedbarezultataanketa2013i2017.pdf (28. 08. 2019.)

Lukić, A., Radeljak Kaufmann, P., 2017: A Scenario-based Approach to Discuss the Future of Croatian Rural Areas: Developing the Conceptual Framework of the CRORURIS Project, in: ISR-Forschungsbericht Heft 43: New developments in the rural space of Central and South-East Europe, Proceedings of the meeting of the Working Group on Central Europe in conjunction with the German Congress of Geography (ed. Jordan, P.), Österreichische Akademie der Wissenschaften, Institut für Stadt- und Regionalforschung, Vienna, 31-47.

Mose, I., Weixlbaumer, N., 2007: A New Paradigm for Protected Areas in Europe?, in: Protected Areas and Regional Development in Europe: Towards a New Model for the 21st Century (ed. Mose, I.), Ashgate, Aldershot Burlington, 3-19.

Pejnović, D., Radeljak, P., 2009: Funkcija rada Nacionalnog parka "Krka” i njezin prostorni utjecaj, Godišnjak Titius 2 (2), 223-238.

Petrić, L., 2008: How to Develop Tourism Sustainably in the Coastal Protected Areas? The Case of "Biokovo Park of Nature", Croatia, Acta Turistica Nova 2 (1), 5-24.

Radeljak, P., 2015: Dalmatinska zagora u perspektivi razvoja Dalmacije do 2031. godine: primjer Grada Drniša, in: Stručno-znanstveni skup Gospodarske mogućnosti Zagore i oblici njihova optimalnog iskorištavanja, Zbornik radova (eds. Matas, M., Rako, A.), Kulturni sabor Zagore - podružnica Zagreb, Institut za jadranske kulture i melioraciju krša, Zagreb - Split, 205-221.

Radeljak, P., Pejnović, D., 2008: Utjecaj turizma na održivi razvoj funkcionalne regije Nacionalnog parka "Krka", Godišnjak Titius 1 (1), 329-361.

\section{Sources}

ArcMap 10.3.1. Basemap, National Geographic World Map.

Croatian Bureau of Statistics (CBS), 2008: Posjetitelji važnijih turističkih znamenitosti i atrakcija u 2007., Priopćenje 44 (4.4.8/4), www.dzs.hr (01. 04. 2012) 
Croatian Bureau of Statistics (CBS), 2009: Posjetitelji važnijih turističkih znamenitosti i atrakcija u 20o8., Priopćenje 45 (4.4.8/4), www.dzs.hr (01. 04. 2012)

Croatian Bureau of Statistics (CBS), 2010: Posjetitelji važnijih turističkih znamenitosti $i$ atrakcija u 2009., Priopćenje 46 (4.4.6/4), www.dzs.hr (o1. 04. 2012)

Croatian Bureau of Statistics (CBS), 2011: Posjetitelji važnijih turističkih znamenitosti $i$ atrakcija u 2010. / Visitors to Main Tourist Sights and Attractions in 2010, Priopćenje / First Release 47 (4.4.8/4), www.dzs.hr (01. 04. 2012)

Croatian Bureau of Statistics (CBS), 2012: Posjetitelji važnijih turističkih znamenitosti i atrakcija u 2011. / Visitors to Main Tourist Sights and Attractions in 2011, Priopćenje / First Release 48 (4.4.8/4), www.dzs.hr (01. 04. 2012)

Croatian Bureau of Statistics (CBS), 2013: Census of population, households and dwellings in 2011: Population by sex and age, by settlements, www.dzs.hr (20. 8. 2014)

Croatian Bureau of Statistics (CBS), n. d.: Naselja i stanovništvo Republike Hrvatske 1857. - 20o1., Šibensko-kninska županija - broj stanovnika po naseljima, www.dzs.hr (20. 08. 2014)

Croatian Geodetic Administration (CGA), 2013: Central Registry of Spatial Units in the Republic of Croatia (GIS shapefiles in accordance with the 2011 census), Zagreb.

Drniš Tourist Board, 2019: Data on tourist arrivals and overnight stays in the Town of Drniš 2010-2018.

eVisitor, 2019: Information system for check-in and check-out of tourists.

Gisdata, 2008: Digital Atlas of the Republic of Croatia (GIS shapefiles).

Krka National Park, 2007: Data on the number of visitors 1996-2006.

Krka National Park, Parks of Croatia, 2018a: Analiza ankete provedene $u$ Nacionalnom parku „Krka“ 2018., http://www.npkrka.hr/upload/stranice/2018/03/2018-03-01/205/analizaankete2018.pdf (29. 08. 2019)

Krka National Park, News, 2018b, http://www.npkrka.hr/clanci/Newsustainable-measures-Skradinski-buk/405/en.html (30. 08. 2019)

Krka National Park, 2019: Data on the number of visitors 2011-2018.

Krka National Park, Unknown Krka project, n. d., http://www.np-krka.hr/ stranice/Unknown-Krka-students-Skradin/220/en.html (o2. 09. 2019)

Republic of Croatia, 2013: Nature Protection Act, Official Gazette 80/2013, 15/2018, 14/2019. 
State Audit Office, Šibenik Regional Office (SAO), 2019: Izvješće o obavljenoj financijskoj reviziji Javne ustanove Nacionalni park Krka za 2017., http:// www.revizija.hr/datastore/filestore/19o/NACIONALNI-PARK-KRKA. pdf (28. 08. 2019) 



\section{Chapter 4 Tourism in protected areas and the transformation of Mljet island, Croatia}

Ivan Šulc

\section{Abstract}

Located in southern Dalmatia, Mljet has some of the best-preserved nature among the inhabited Adriatic islands, and the western part was declared a national park in 1960. After World War II, the island faced intensive depopulation and transformation from an agriculture-oriented economy to a service-oriented economy. This chapter investigates the role of tourism in the socio-economic transformation of the island and the social pressure of tourism on the small local community. The goals were to investigate the role of tourism in demographic processes on Mljet, its impact on the socio-economic development of the island, and to measure the pressure of tourism on the local community. The research confirmed the significant role of tourism in the island's socio-economic and demographic transformation, but it also revealed some of the highest levels of social pressure due to tourism in southern Dalmatia, which is not acceptable for a tourism area with a highly-preserved natural environment.

Key words: protected area, nature-based tourism, coastal tourism, depopulation, social pressure of tourism, islands, geography, Mljet, Croatia 


\section{Introduction}

Coastal regions in the Mediterranean have experienced very intensive tourism development since the end of World War II, which has been even more amplified on islands (Bramwell, 2003). Rapid development of coastal tourism, based on attracting broad masses of tourists, is associated with strong expansion of hotels and other accommodation capacities (often of lower quality) (Ioannides, 2001; Andriotis, 2006; Chapman and Speake, 2011). Tourism gives an impulse to the economic development of local communities that otherwise would not have any development opportunities outside of agriculture, but has also caused large changes in coastal landscapes and the transformation of rural settlements into urbanised tourism areas (Andriotis, 2006).

Unfortunately, unplanned tourism development in some areas has generated negative environmental, socio-cultural, and economic impacts, and deteriorated the perceived attractiveness of destinations for potential tourists, who have started choosing less-transformed areas (Ioannides, 2001; Andriotis, 2006; Pulina and Biagi, 2006; Garay and Cànoves, 2011). In areas with high physical and social pressure of tourism, a part of the population has also started to feel the negative aspects of tourism, especially on the part of the population that is not directly involved in tourism (Doxey, 1975; Butler, 1980; Black, 1996; Bramwell, 2003). Bossevain and Theuma (1998) associate such negative attitudes with the development of "quality" tourism products that rapidly consume scarce natural resources, due to large infrastructural requirements (e.g. upscale hotels, marinas, golf courts) and demands for large amounts of land and natural resources. However, Zhong et al. (2008) showed, in the case of Zhangjiajie National Park in China, that negative impacts of tourism are not confined only to coastal areasthey can also affect natural areas on the mainland. Furthermore, the case of Plitvice Lakes, the national park the most threatened by over-tourism in Croatia, speaks in favour of the aforementioned theses.

The course and characteristics of tourism development in Croatia has largely followed the trends in the broader Mediterranean area, with one major difference: development took place under two different socio-economic systems (socialist and capitalist) and was completely halted by the Croatian War of Independence (1991-1995) (See: Šulc, 2017). Furthermore, tourism urbanisation has been dominated by new construction or reconstruction of private houses with apartments and rooms available for rent to tourists, while there were relatively few hotels (Šulc, 2016; 2019). These processes 
spread from the mainland to the islands later, and caused severe transformations in some small island communities (See: Starc, 2001; Faričić et al., 2010; Šulc and Zlatić, 2014; Šulc, 2016). Only protected areas in the coastal zone, with stricter regulation regimes, remained partially spared from unplanned and chaotic tourism construction. At the same time, most islands experienced highly negative demographic processes (Nejašmić, 1992; Lajić, 2006; Lajić and Mišetić, 2006; Nejašmić and Mišetić, 2006), which have only recently begun to show signs of improvement.

This chapter, therefore, investigates to what extent tourism has contributed to demographic changes and socio-economic processes on Croatian islands, using the case of Mljet, a medium-sized Adriatic island with a highly-preserved natural environment and a small population. Goals of the chapter are: (1) to investigate the role of tourism in demographic processes on Mljet; (2) to determine the impact of tourism on the socio-economic development of the island; and (3) to measure the intensity of the pressure of tourism on the local community.

\section{Research methods}

The research is based on "desk" methods that involve the analysis of data on tourism, population, and vital events. Statistical data on tourism consist of the number and structure of tourist arrivals, overnight stays (from 1966 to 2016), and tourist beds (from 1976 to 2016). Data was not analysed on a yearly basis, rather every fifth year was compared. Data was used in its original form to analyse tourism development and as combined indicators to estimate the social pressure of tourism-tourism function index (number of tourist beds per 100 inhabitants) and tourism intensity (number of tourist arrivals per 100 inhabitants).

The analysis of demographic processes used census data from the 1961-2011 period, consisting of population size, migration features, age-sex composition, education, economic activity, sector of activity, and agricultural population. Despite the changes in the methodology of censuses (censuses from 1961, 1971, 1981, and 1991 used de jure methodology and the 2001 and 2011 censuses used place of usual residence), the minor discrepancy in the population stemming from different methodologies is irrelevant for the purposes of this research and data was used in its original form. It is important to note that data on sector of economic activity was not available for 1981 , as well as data on agricultural population for 2011, which is no longer registered in censuses. 
Census data were used in the analysis of the demographic and socio-economic transformation of Mljet as absolute numbers (number of inhabitants), the share of certain segments of the population relevant for the analysis, or as relative indicators (education index, activity rate etc.). Classifications (percentage) of the population according to population composition are:

(1) age composition-young (o-14 years), adult (15-64 years), and elderly population (aged $65+$ );

(2) migration features-population that has always lived in the same settlement and population that moved from other settlements in the same municipality, other municipalities, other counties, or from abroad;

(3) educational composition-population without primary education $\left(<E_{I}\right)$, with primary education (elementary school; $\left.E_{I}\right)$, with secondary education (high school; $E_{I I}$ ), and with tertiary education (two-year study or more; $E_{I I I}$ );

(4) composition by economic activity-active, dependent, and population with income; and

(5) composition of the active population by sector of activity-primary, secondary, and tertiary sectors.

The active population consisted of employed persons, active farmers, and unemployed persons; the population with income consisted of retired persons and those with other sources of income; while the dependent population included all other economically inactive persons (See: Nejašmić, 2005). Primary sector activities comprised economic activities (agriculture, forestry, and fishing) of group A according to the Statistical Classification of Economic Activities, the secondary sector included groups $\mathrm{B}-\mathrm{E}^{\mathrm{I}}$, and the tertiary sector groups $\mathrm{F}-\mathrm{U}^{2}$ (CBS, 2007a). The analysis was based on the following combined indicators: (1) index of total population change; (2) age in-

1 Secondary economic activities are: B) mining and extraction; C) manufacturing industries; D) supply of electric energy, gas, steam and air conditioning; E) water supply, waste water treatment, waste management, and environmental sanation; and F) construction (CBS, 2007a).

2 Tertiary economic activities are: $\mathrm{G}$ ) retail and wholesale, repair of motor vehicles; $\mathrm{H}$ ) transport and storage; I) accommodation and catering services; J) information and communication; K) financial and insurance services; L) real estate affairs; M) professional, scientific, and technical activities; N) administrative and support services; O) public administration and defence, obligatory social security; P) education; Q) health services and social care; R) education, entertainment, and recreation; S) 
dex-number of elderly per 100 young inhabitants; (3) old age coefficientnumber of elderly per 100 adult inhabitants; (4) average age; (5) educational index (calculated according to the formula $E_{I}=E_{I I} \cdot E_{I I I} /<E_{I}$ ); (6) activity rate (of the total population)-share of active inhabitants in the total population; and (7) labour force participation rate-share of active inhabitants in the adult population (aged 15-64) (See: Nejašmić, 2005).

The demographic analysis also used the number of live births and deaths in the settlement from the vital statistics in the 1964-2011 period. As data was used as absolute numbers in ten-year census periods, the number of vital events in the 1961-1971 period was estimated using the seven-year average in the 1964-1970 period. These data were used to calculate the natural increase and net migration in ten-year census periods, by subtracting the natural increase from the total population change.

\section{Tourism on the island Mljet}

With a surface area of $99.3 \mathrm{~km}^{2}$, the island Mljet extends $37 \mathrm{~km}$ in a northwest-southeast direction and has a maximum width of $3 \mathrm{~km}$. In 1960, the western part of the island was declared a protected area (Mljet National Park), due to its highly indented coast with two connected bays (called the Big Lake and the Small Lake), numerous islands and specific marine geomorphological forms, as well as preserved natural vegetation consisting of Aleppo pine, Holm oak, and macchie. Around $70 \%$ of the island is covered by autochthonous forests, representing one best-preserved environments found among Adriatic islands. The island is administratively governed by the Municipality of Mljet and has 14 settlements-three within Mljet National Park (Goveđari, Polače, Pomena), five located in the island's interior (Babino Polje, Blato, Korita, Maranovići, Prožura), and six on the coast (Kozarica, Okuklje, Prožurska Luka, Ropa, Saplunara, Sobra). This chapter focuses on the period of the 1960 s to the time of writing, which has been marked by intensive socio-economic processes and tourism development.

Tourism on the island Mljet started to develop quite late compared to other destinations in southern Dalmatia, due to poor transport connections and isolation. The first tourists visited the western part of the island in 1924 and the first accommodation facility opened next to the Big Lake in 1934 (Šubić, 1995; Pansion Jezero, 2015). World War II seriously interrupted tourism development, which took almost a decade to recover (Šulc,

other services; T) activities of households as employers and for the needs of personal households; $\mathrm{U}$ ) activities of extra-terrritorial organisations and bodies (CBS, 2007a). 
2017). In the mid-1950s, residents in Goveđari, a settlement located next to the lakes, started to rent rooms in their houses to tourists but only few domestic tourists were visiting the island at the time (Šubić, 1995). The turning point in tourism development was the establishment of Mljet National Park in 1960, the construction of the first hotel on St. Mary's Island in the Great Lake, and the construction of communal infrastructure (Šubić, 1995; Šulc, 2017). Tourists were attracted by preserved and protected nature, associated with opportunities for a "sun and sea" holiday. Most of them would come in summer and stay within the Park; though the island was spared from mass tourism (in 1966 it recorded 1,603 tourist arrivals and 15,985 overnight stays, all in Mljet National Park) (Tab. 1).

In the 1970s, overnight tourism started to develop extensively outside the Park in the small coastal settlements Sobra and Okuklje, but it was limited to a few private households (Šulc, 2017). In 1978, Hotel Odisej (with 400 beds) was built in Pomena, the entry port to the National Park, which is the largest project on the island to date (Šulc, 2017). Increases in accommodation capacity were not followed by a cooresponding increase in the number of beds, due to inconsistent registration, but it resulted in rapid increases in tourism. In 1986, the pre-war peak year, the island registered 11,086 arrivals and 85,718 overnight stays, almost all in the Park (Tab. 1). The tourism supply remained unchanged and based on the "sun and sea" concept in highly-preserved natural area, with a rather long average stay of 7.7 nights. The Park is also a favourite destination for day-trippers from Dubrovnik, Pelješac Peninsula, and the nearby islands Hvar and Korčula (Šulc, 2017).

In the late 1980s, tourism started to show the first signs of crisis (Šulc, 2017) and it completely declined when the War started in the early 1990 os. New tourism growth was initiated by the re-opening of the Hotel Odisej in 1993 and continued to increase up to 2006, when the island reached its pre-war level of visitation (14,707 arrivals and 70,036 overnight stays). In the meantime, the other hotel closed and more residents got involved with tourism by renting apartments in their households. Consequently, in 2006, the share of the Park in all tourist beds decreased to $48 \%$, while coastal settlements reached $40 \%$ and interior settlements $12 \%$ (Tab. 1). Although the structure and travel habits of tourists changed, spending summer holidays in a preserved natural environment remained the most important motivation for visitors, due to which the Park still registered $75 \%$ of all tourists on the island. 
Tab. I Tourist arrivals, overnight stays, and tourist beds on Mljet in the 1966-2016 period, by groups of settlements

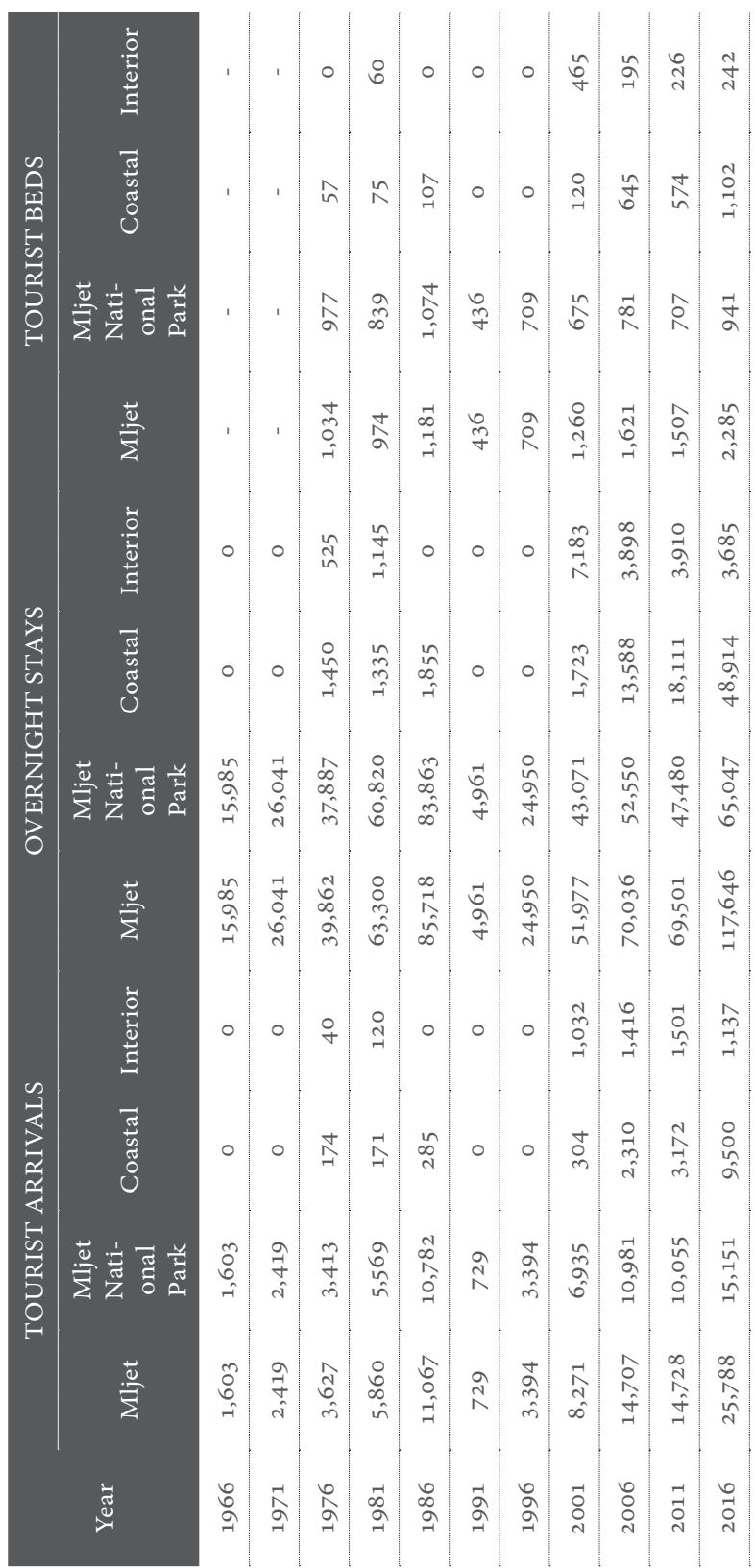

Sources: RBS (1967; 1972; 1977; 1982; 1987); CBS (1992; 1997; 2002; 2007b; 2012; 2017) 
The period of stagnation that followed in the late 2000 s was generated by the economic crisis on the main international tourist markets, the island's underdeveloped and stagnant tourism supply, and the fickle nature of tourists' preferences (Šulc, 2017). Concurrently, almost all settlements became involved in tourism by offering similar tourism products. Economic recovery after 2011 and improvements in the tourism supply in Croatia managed to stimulate new and intensive tourism growth, which was, on Mljet, connected with rather high increases in private accommodation in coastal settlements (particularly Saplunara and Sobra) and in the Park, but less in interior settlements (Babino Polje, Blato). Therefore, in 2016, accommodation capacities reached 2,285 beds, twice as much as in 1986 , and coastal settlements (48\%) outnumbered the Park (41\%) in terms of beds (Tab. 1). The rather unfavourable structure of beds $(15.1 \%$ in a hotel, $13.7 \%$ in camps, and $71.2 \%$ in private households) generates very low net occupancy (51.5 days) (CBS, 2017). In 2018, there were 247 registered private owners and small businesses that offered rooms and apartments for rent (Mljet Tourist Board, 2019). Tourist arrivals $(25,788)$ and overnight stays $(117,646)$ are also significantly higher than before the War, with a growing share among coastal settlements (37\% and $42 \%)$. Tourism is mostly oriented towards international tourist markets ( $85 \%$ of overnight stays), led by Slovenia (14\%), Germany (11\%), France (8\%), and the UK (8\%) (CBS, 2017). The rather short average stay (4.6 days) reflects dominant coastal and nature-based tourism in conditions of an underdeveloped tourism supply and trends of shorter holidays on tourist markets.

\section{Can tourism revitalise the population of Mljet?}

A positive answer to this question is often given without prior in-depth analysis and consideration of the complex demographic and socio-economic processes within the population. This section aims to give an insight into multi-factored demographic processes and how much tourism has contributed to them. The analysis is based on total population change, net migration, share of migrants, and age composition in the 1961-2011 period.

The total population of Mljet (1,088 in 2011) is very low compared to other Croatian and Mediterranean islands of similar size and makes up less than $1 \%$ of the population of southern Dalmatia (Tab. 2). In the past, the island was isolated from major population cores and almost all of its people lived in small old rural settlements in the island's interior, and worked in agriculture (e.g. Babino Polje, Blato, Goveđari, Korita, Maranovići, 
Tab. 2 Changes in the population of Mljet by groups of settlements in the 196I-2011 period

\begin{tabular}{ccccccccc} 
& \multicolumn{3}{c}{ Population } & \multicolumn{5}{c}{ Index of total population change } \\
\cline { 2 - 9 } & Mljet & $\begin{array}{c}\text { Mljet } \\
\text { National } \\
\text { Park }\end{array}$ & Coastal & Interior & Mljet & $\begin{array}{c}\text { Mljet } \\
\text { National } \\
\text { Park }\end{array}$ & Coastal & Interior \\
\hline 1961 & 1,963 & 381 & 103 & 1,479 & - & - & - & - \\
\hline 1971 & 1,638 & 335 & 92 & 1,211 & 83.4 & 87.9 & 89.3 & 81.9 \\
\hline 1981 & 1,395 & 315 & 118 & 962 & 85.2 & 94.0 & 128.3 & 79.4 \\
\hline 1991 & 1,237 & 352 & 182 & 703 & 88.7 & 111.7 & 154.2 & 73.1 \\
\hline 2001 & 1,111 & 317 & 231 & 563 & 89.8 & 90.1 & 126.9 & 80.1 \\
\hline 2011 & 1,088 & 316 & 334 & 438 & 97.9 & 99.7 & 144.6 & 77.8 \\
\hline & & Index 1991/1961 & & 63.0 & 92.4 & 176.7 & 47.5 \\
\hline
\end{tabular}

Sources: FBS (1965; 1972); RBS (1983); CBS (1994; 2003; 2013)

Prožura). New coastal settlements took shape mostly in the $20^{\text {th }}$ century (particularly after World War II) around former warehouses and storage buildings in protected bays, due to tourism development (e.g. in Kozarica, Okuklje, Polače, Pomena, Prožurska Luka, Ropa, Saplunara) (Šulc, 2016). The only older coastal settlement is Sobra, which is the island's main port. Today, none of the island's settlements have more than 500 inhabitants; furthermore, the largest is the central settlement Babino Polje with 270 inhabitants; 7 have a population of 100 to 200, and 6 have less than 100 (Fig. 1).

The present settlement structure is largely result of population change in the 1961-2011 period. In 1961, before the most intensive tourism development took place, the island had a population of 1,963 (FBS, 1965). Most of them worked in traditional labour-intensive agriculture, and the island was marked by agricultural overpopulation. In the 196os, there was a mass exodus from agriculture and the island, as people left for work in Yugoslavia's blossoming industrial centres (Stražičić, 1969; Šulc and Valjak, 2012). As tourism on the island was in its infancy, it could not absorb the entire workforce (Šulc and Valjak, 2012) and other economic activities were almost non-existant.

The younger population used to leave the island due to the poor job market and also because of social opportunities offered by life in cities. Hence, in the 1961-1971 period, 321 more people left the island than moved 


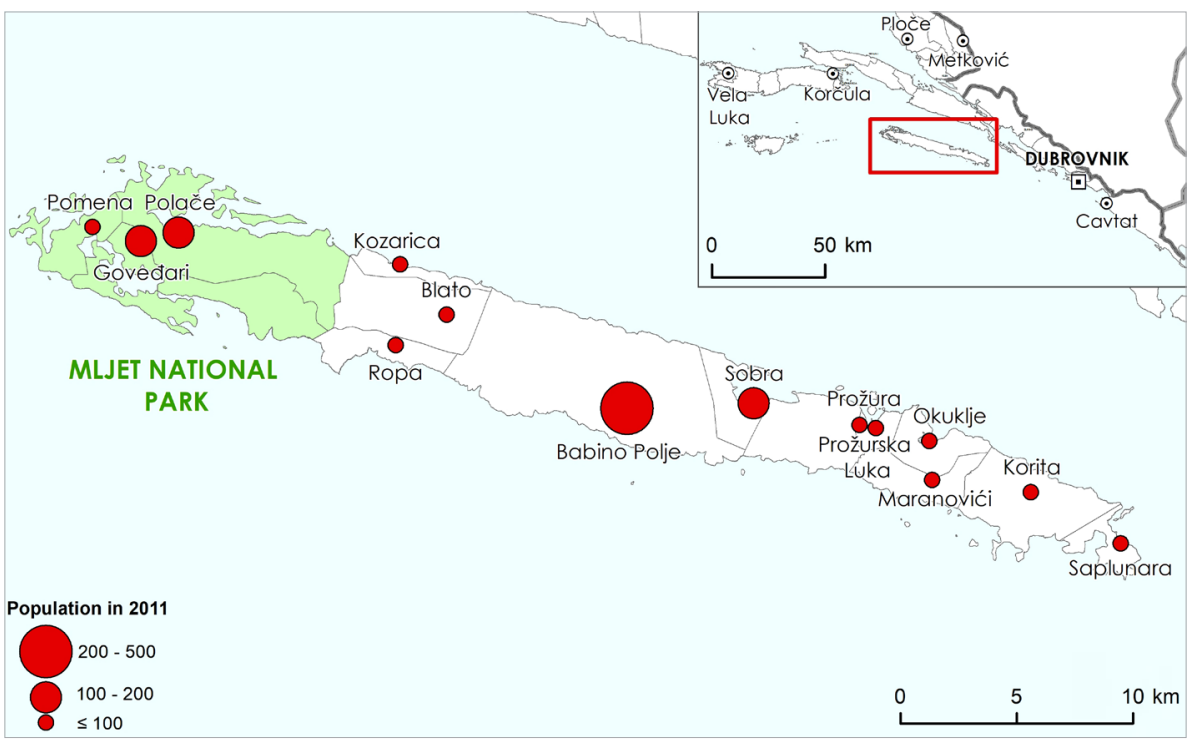

Fig. I Settlements on the island Mljet by population in $201 \mathrm{I}$

Sources: CBS (2013); CGA (2016)

to it, representing one-sixth of the population in 1961, and generating negative natural increase and a total depopulation of $14.8 \%$. As expected, interior rural settlements were the most affected by out-migration, but settlements in Mljet National Park were almost equally hit.

In the 1971-1981 and 1981-1991 periods, the population of the island continued to decrease with a lower intensity (by $14.8 \%$ and $11.3 \%$ ), and a declining rate of out-migration (Tab. 2). Moderate growth in tourism in both periods might be responsible for lower out-migration (Tab. 3), however, it is also inevitably related to the exhausted potential migrant contingent, i.e. those who wanted to leave the island had already left (See: Nejašmić, 1999; 2013). In the meantime, highly negative natural increase became main force of depopulation, due to previous selective out-migration that resulted in a disrupted age-sex composition.

On the other hand, instead of migration from the island, a part of the population moved from interior to the settlements in the Park and the coast, most probably due to tourism (renting accommodation, restaurants, tourism services in the Park, etc.) (Tab. 3). The island still could not manage to pull more people from the mainland that would stay there permanently, however, as the economic structure in most island regions was far simpler than on the mainland, and highly seasonal tourism usually did not offer year-round employment (Šulc, 2016). 
Tab. 3 Total population change (TPC), natural increase (NI), and net migration (NM) on Mljet by groups of settlements in the 196I-201 period

\begin{tabular}{|c|c|c|c|c|c|c|c|c|c|c|c|c|}
\hline \multirow{2}{*}{ Period } & \multicolumn{3}{|c|}{ Mljet } & \multicolumn{3}{|c|}{$\begin{array}{c}\text { Mljet National } \\
\text { Park }\end{array}$} & \multicolumn{3}{|c|}{$\begin{array}{c}\text { Coastal } \\
\text { settlements }\end{array}$} & \multicolumn{3}{|c|}{$\begin{array}{l}\text { Interior settle- } \\
\text { ments }\end{array}$} \\
\hline & TPC & NI & NM & $\mathrm{TPC}$ & $\mathrm{NI}$ & NM & $\mathrm{TPC}$ & NI & NM & $\mathrm{TPC}$ & NI & NM \\
\hline $1961-1971$ & -325 & -4 & -321 & -46 & 3 & -49 & -11 & -4 & -7 & -268 & -3 & -265 \\
\hline $1971-1981$ & -243 & -124 & -119 & -20 & -25 & 5 & 26 & -1 & 27 & -249 & -98 & -151 \\
\hline $1981-1991$ & -158 & -121 & -37 & 37 & 8 & 29 & 64 & -6 & 70 & -259 & -123 & -136 \\
\hline $1991-2001$ & -126 & -123 & -3 & -35 & -22 & -13 & 49 & 2 & 47 & -140 & -103 & -37 \\
\hline $2001-2011$ & -23 & -128 & 105 & -1 & -26 & 25 & 103 & -9 & 112 & -125 & -93 & -32 \\
\hline $1961-2011$ & -875 & -500 & -375 & -65 & -62 & -3 & 231 & -18 & 249 & -1041 & -420 & -621 \\
\hline
\end{tabular}

Sources: FBS (1965; 1972); RBS (1983); CBS (1965-2012; 1994; 2003; 2013)

Depopulation continued in the 1991-2011 period, mostly due to highly negative natural increase, resulting in 1,088 inhabitants in 2011 (Tab. 2). Net migration almost reached zero change in the 1991-2001 period, despite the War and crisis in tourism, while the 2001-2011 period was even characterised by positive net migration. Lower out-migration might be associated with the fact that some of the younger population chose to return to the island after they finished their education, due to better employment opportunities related to tourism and the Park. In-migration is mostly motivated by private reasons (e.g. marriage, family) and comprises a contingent of former second home owners that move to the island permanently (seasonally or year-round).

Depopulation is indeed the main demographic process on Mljet. From 1961 to 2011 the island lost $44.6 \%$ of its population, out of which $57 \%$ was by negative natural increase and $43 \%$ by negative net migration (Tab. 2 and 3 ). Along with Lastovo, it represents the largest population loss of all southern Dalmatian areas (e.g. Pelješac lost $17 \%$ of its population, Korčula $14 \%$, Konavle $2 \%$ ), while the population in southern Dalmatia as a whole increased by $23 \%$ (See: Šulc, 2016).

In the same time, the island has experienced a strong redistribution of its population. In $1961,75 \%$ of people lived in the interior of the island where the main agricultural areas are located, $20 \%$ lived in the Park, while only $5 \%$ lived on the coast. In 2011, interior settlements had only $40 \%$ of the population, the Park $29 \%$, while the share in coastal settlements had reached 
31\% (Tab. 2). What caused such a remarkable change? Interior settlements lost two-thirds of their population due to complete deagrarisation, which was not substituted by other economic activities. Having no working opportunities, the younger population was forced to leave and some of them saw tourism in coastal settlements as a potential source of income (Šulc and Valjak, 2012).

Hence, the population in coastal settlements increased by over threefold. Apart from Sobra, these small settlements developed from small agglomerations that consisted of storage buildings and warehouses for boats, owned by residents of interior settlements. Tourism development, starting in the 1970s, encouraged the transformation of existing objects and the construction of new ones as rental accommodation for tourists. This was perhaps sufficient to keep more of the local population on the island (Šulc and Valjak, 2012), but it was certainly not enough to attract potential migrants from the mainland. During the same period, the population of the Park decreased by $18 \%$, due to less intensive in-migration, associated with limited building permits, which, on the other hand, spared that area from over-construction (Šulc and Valjak, 2012). Despite its role as the tourist centre of the island, many who work in the Park choose to live in other parts of the island (Šulc and Valjak, 2012).

The analysed processes show that tourism did not manage to revitalise the population, but it contributed to divergent population development in the interior and on the coast, as well as in settlements within the Park. Another issue is the small size of the settlements, which generally lack an economically active population and initiatives, limiting tourism to the simple "sun and sea" paradigm, i.e. renting accommodation in households, and does not enable the full potential of the island to be realised.

The analysed spatial mobility is visible in the composition of the population by migration features in 2011. Around $54.5 \%$ of the population moved to their present place of residence (i.e. they did not always live there), which is above the regional average (49.2\%), and confirms the rather vivid documented migration in the recent period (CBS, 2013). Furthermore, $34.4 \% \mathrm{mi}-$ grated from another place on the island, as a part of the recent population redistribution. The share of migrants from the rest of Dubrovnik-Neretva County is equally high (32.9\%), comprising former islanders that had moved to Dubrovnik and returned to the island to retire, as well as their children, who see tourism as a source of income (CBS, 2013; Šulc, 2016). The lower share of in-migrants from other Croatian regions (15.5\%) and other coun- 
tries (17.2\% - half of them from Bosnia and Herzegovina) shows that extensive tourism management does not pull in people from distant regions effectively (CBS, 2013).

\section{Age composition}

Tourism impact on the population is the best visible in age composition, which is a reflection of past and present population change. In 1961, the population of Mljet was affected by ageing, with $\mathbf{1 2 . 3 \%}$ elderly population, and age index of 48.4, and an average age of 34.5 years (Tab. 4). It was not much worse than the average of southern Dalmatia (10.3\% of elderly, age index of 38.6 and average age of 32.7) (Šulc, 2016). Small differences among regions reflected lower intensity of migration with a high orientation towards agriculture, which had been keeping younger population in the region until this point.

Intensive age and sex selective out-migration from Mljet and subsequent natural increase resulted in the oldest population in southern Dalmatia in 1991, visible in share (28.8\%) of elderly population, an age index of 183.8 , and a very high average age of 45.4 (Tab. 4 ). Unlike 30 years earlier, the island's population was much older than the regional average that was $12.8 \%$ elderly people, with an age index of 61.8 , and an average age of 36.o years (Šulc, 2016). Therefore, we cannot confirm that extensive tourism development in the socialist period contributed to slower ageing on Mljet.

Rapid population ageing continued after the War and did not show any signs of slowing. In 2011, Mljet had the oldest population in southern Dalmatia, with a share of elderly population 2.5 times greater than young population (28.2\% to $11.1 \%)$, and extremely unfavourable indicators-an age index of 253.7, old age coefficient of 28.2, and average age of 47.0 years. The population of southern Dalmatia was less aged, with $17.8 \%$ elderly population, an age index of 109.7, 27 elderly to 100 adults, and an average age of 41 years (Šulc, 2016).

Even intensified (but still low) levels of tourism development and positive net migration in the recent period did not manage to slow decades of demographic momentum. The ageing population is now under the influence of demographic inertia (particularly due to the disrupted age-sex composition and negative natural increase) (See: Nejašmić, 2013), which can be changed only with intensive in-migration. In particular, there is negative ageing of the working contingent that generates economic development potential and new initiatives. These processes correspond to the 
Tab. 4 Indicators of age composition on Mljet in 196I, 1991, and 2011, by groups of settlements

\begin{tabular}{|c|c|c|c|c|c|c|c|}
\hline & Year & $\begin{array}{c}\text { Young } \\
\text { (o-14 } \\
\text { years) (\%) }\end{array}$ & $\begin{array}{c}\text { Adults } \\
(15-64 \\
\text { years) }(\%)\end{array}$ & $\begin{array}{c}\text { Elderly } \\
(65+ \\
\text { years })(\%)\end{array}$ & Age index & $\begin{array}{c}\text { Old age } \\
\text { depen- } \\
\text { dency } \\
\text { ratio }\end{array}$ & $\begin{array}{c}\text { Average } \\
\text { age }\end{array}$ \\
\hline \multirow{3}{*}{ Mljet } & 1961 & 25.3 & 62.4 & 12.3 & 48.4 & 19.6 & 34.5 \\
\hline & 1991 & 15.3 & 56.7 & 28.0 & 183.8 & 49.4 & 45.2 \\
\hline & 2011 & 11.1 & 60.7 & 28.2 & 253.7 & 46.5 & 47.0 \\
\hline \multirow{2}{*}{$\begin{array}{l}\text { Mljet } \\
\text { National Park }\end{array}$} & 1991 & 22.2 & 58.5 & 19.3 & 87.0 & 33.0 & 38.6 \\
\hline & 2011 & 12.0 & 66.1 & 21.8 & 181.6 & 33.0 & 44.0 \\
\hline \multirow{2}{*}{$\begin{array}{l}\text { Coastal } \\
\text { settlements }\end{array}$} & 1991 & 19.2 & 63.8 & 16.9 & 88.2 & 26.5 & 40.6 \\
\hline & 2011 & 13.5 & 64.1 & 22.5 & 166.7 & 35.0 & 44.0 \\
\hline \multirow{2}{*}{$\begin{array}{l}\text { Interior } \\
\text { settlements }\end{array}$} & 1991 & 10.7 & 54.0 & $35 \cdot 3$ & 328.4 & 65.3 & 49.6 \\
\hline & 2011 & 8.7 & 54.1 & 37.2 & 428.9 & 68.8 & 51.4 \\
\hline
\end{tabular}

\section{Sources: FBS (1965); CBS (1994; 2013)}

growing share of accommodation in households, which has turned tourism into the main complementary activity of the population instead of professionalising it.

However, differences among groups of settlements revealed that tourism might have had limited local impacts on population ageing, related to the previously analysed population redistribution. Coastal settlements and settlements in Mljet National Park have significantly younger populations than the island's average (but still aged), as a result of recent in-migration related to working opportunities in tourism and the Park, port, and other related economic activities. Depopulating interior settlements, as expected, have deeply aged populations and fewer opportunities for further demographic and socio-economic development (Tab. 4).

The analysis confirmed that direct connections between tourism development and demographic changes cannot be drawn, as both are influenced by many different factors (See: Zupanc et al., 200o). Effects of tourism on population revitalisation (or at least slower negative processes) have been limited even in regions with more intensive tourism development and cannot not be separated from wider socio-economic processes (Šulc, 2016). Besides being at least a decade late compared to the coast, tourism on Croatian islands developed in step with serious depopulation and pop- 
ulation ageing processes, which can be considered to be partially responsible for the less-developed tourism supply and difficulties in attracting newcomers from the mainland (Šulc, 2016). Higher levels of tourism development inevitably require a larger, adequately educated population, with high levels of initiative and interest in continual development of the tourism supply (Šulc, 2016).

\section{Socio-economic impacts of tourism}

The analysis of the socio-economic impact of tourism aims to determine to what level tourism influenced social and economic processes on the island, as well as how much the population is pressured by tourism. These processes were determined by investigating changes in educational composition, economic activity, and indicators of social pressure of tourism since 1961.

The educational composition of the population consists of "human capital" and it is one of the most important characteristics of the population in terms of potential economic development (Nejašmić, 1998; Nejašmić et al., 2009). In the 1961-2011 period, Mljet's population experienced large improvements in educational composition, but it always lagged behind the regional average. In 1961, the educational level was rather low-the education index was 0.0 , as $88 \%$ of the population had not even finished primary school, $7 \%$ had a primary school level education, $4 \%$ had a high school education, and only handful had a tertiary-level education (o.1\%) (Tab. 5).

Due to high orientation towards traditional agriculture, people used to only finish elementary school (or not attend school at all) and then start working in agriculture with their families. Bottom-up development of tourism was not something the one would expect. However, Mljet was not an exception at that time, as most of southern Dalmatia was still oriented towards agriculture and the regional average was just slightly higher (educational index was $0.3 ; 77.3 \%$ of the population had not finished elementary school, 9.5\% had a primary school level education, $11.4 \%$ had a secondary school level education, and 1.8\% had a tertiary-level education) (FBS, 1965).

In the following decades, the education composition of Mljet improved slowly, resulting in an educational index of only 1.9 in 1991, due to a persistently high share of people without any education (52\%) and only 5\% with tertiary-level education. Having no working opportunities outside agriculture, intensive out-migration in the 1960 s and 1970 s included the island's particularly educated inhabitants and resulted in the absence of an appropriate socio-economic transformation led by tourism, as was com- 
mon in other areas, and small improvements in the educational composition. Even moderate development of tourism in the Park in the 1980s had little effect on education level; its small improvements were part of general social development.

Tab. 5 Education composition of the Mljet population aged Is and above, in 196I, 199I, and 2011

\begin{tabular}{cccccc} 
Year & $\begin{array}{c}\text { Unfinished } \\
\text { primary } \\
\text { education }\end{array}$ & $\begin{array}{c}\text { Primary } \\
\text { education }\end{array}$ & $\begin{array}{c}\text { Secondary } \\
\text { education }\end{array}$ & $\begin{array}{c}\text { Tertiary } \\
\text { education }\end{array}$ & $\begin{array}{c}\text { Education } \\
\text { index }\end{array}$ \\
\hline 1961 & 88.4 & 7.2 & 4.3 & 0.1 & 0.0 \\
\hline 1991 & 52.2 & 22.7 & 20.3 & 4.9 & 1.9 \\
\hline 2011 & 11.7 & 27.3 & 49.4 & 11.6 & 49.0 \\
\hline
\end{tabular}

Sources: FBS (1965); CBS (1994; 2013)

Since the island had only an elementary school, those who had wanted to continue their education had to go to Dubrovnik or other cities and rarely returned to live on the island later, as there were no jobs for them outside of agriculture and poorly-developed tourism. On the other hand, developing a complex tourism supply, based on several types of tourism in as long a period as possible during the year, was not possible without a critical mass of highly-educated people. In the same period, southern Dalmatia experienced a strong economic transformation and tourism development, followed by large improvements in education levels. In 1991, the educational index reached 18.1 , with $25.1 \%$ of the population with no education, $32.5 \%$ with a primary-level education, $41.4 \%$ with a secondary-level education, and $11.0 \%$ with a tertiary-level education (CBS, 1994).

Data in 2011 revealed that the education level on Mljet has greatly improved (educational index 49.0), mostly due to the declining share of people with no education ( $12 \%$-in older age groups) and the growing share of people with secondary-level education (49\%) (Tab. 5). Despite stimulating higher education, increases in the share of well-educated people is still below expectations (12\%). Many young people decide not to study, since they find secondary-level education sufficient to work in tourism, while those who have studied rarely return due to the lack of jobs that require a university degree. Despite the improvements, Mljet still has one of the least-educated populations in southern Dalmatia, with an average educational in- 
dex of $128.6,8.1 \%$ with no education, $27.5 \%$ with primary-level education, $55.6 \%$ with secondary-level education, and $18.8 \%$ with tertiary-level education (CBS, 2013).

The analysis confirmed that it is not possible to draw a direct connection between tourism development and the level of education. Nevertheless, urban tourism areas with more educational institutions and larger job markets attract educated migrants and incentivise young people to stay in the area after their education. Concurrenly, rural tourism areas with lower education levels are limited to extensive tourism development that does not attract newcomers that are more educated.

\section{Tourism and transformation of economic activities}

Analysis of impacts of tourism on economic activity on Mljet was investigated using changes in the composition of the population by economic activity (active, with income, and dependent), in the composition of active population by sector of activity (primary, secondary, tertiary), share of agricultural workers in the total population, and labour force participation rate from 1961 to 2011.

The two main processes present on Mljet in the investigated period were the decrease in economic activity and transformation from agricultural to service economy (Tab. 6). In 1961, Mljet was an example of a typical agricultural region with $81 \%$ of its active population working in the primary sector. Agriculture was not specialised or professional and it usually represented a family businesses in which all members participated. Lower productivity was additionally influenced by small land parcels and agricultural overpopulation (the agricultural population was $69 \%$ of the total population) (FBS, 1965). The secondary sector employed 6\% of the population, mostly in trades/crafts and construction, while only $13 \%$ worked in services. The high share of active population (51\%) used to hide potential surpluses of workforce in agriculture, which is also visible in the high labour participation rate (81\%) (Tab. 6). Many elderly persons did not have a pension and still worked in agriculture, so only $2 \%$ of the population had a personal income.

In the 196os, Mljet was not much different from other rural regions that still had not experienced development of tourism and other non-agricultural activities, and where its relative remoteness prevented regular commuting to work in cities, which resulted in intensive out-migration. However, other parts of southern Dalmatia had already experienced a tran- 
sition to a service economy, stimulated by tourism development that was still limited to large tourist resorts, while industry had a transformative role only in some small communities ${ }^{3}$.

In the 1960s, Mljet experienced intensive deagrarisation followed by moderate out-migration, which was further intensified in the 1970s, due to slow and insufficient tourism development that still had the main transformative role, along with activities related to Mljet National Park (in 1971, the share of agricultural population was $27 \%$ and had fallen to $9 \%$ by 1981 ). By 1991, the socio-economic transformation of the island was finished, when the share of agricultural population reached its minimum of $5 \%$, which has persisted to the time of writing (CBS, 1994). Services became the predominant occupation for $82 \%$ of the active population, while $15 \%$ still worked in agriculture, and only $3 \%$ in the secondary sector (Tab. 6) ${ }^{4}$.

The population in the western part of the island mostly worked in services related to tourism and the Park, while in the eastern part of the island, port activities, transport, and administration employed more of the active population than tourism. Good agricultural resources in the central part of the island were still used for crop cultivation, as opposed to services in terms of work opportunities. However, these processes did not result in professionalisation of agriculture, rather in the abandonment of less fertile land and the spread of a depopulation landscape (See: Nejašmić, 1991). In the same period, the activity rate decreased to $34 \%$, accompanied by one of the lowest labour force participation rates in the region (58\%). Low activity was associated with the model of tourism, that relied on renting accommodation in households and did not enable year-round jobs, as well as with serious population ageing, which was visible in growing share of persons with income $(27 \%)^{5}$.

3 In 1961, southern Dalmatia had $41 \%$ active population, $6 \%$ had a personal income, and $53 \%$ were dependent, while the labour force participation rate was $63 \%$ (FBS, 1965). Primary sector workers were the largest group (47\%), followed by secondary (21\%), and services (32\%), while the share of agricultural population was $39 \%$ (FBS, 1965).

$4 \quad$ Mljet followed the patterns experienced throughout southern Dalmatia, which, in 1991 , had $7 \%$ of its working population in agriculture, $20 \%$ in the secondary sector, and $73 \%$ in services, while the share of agricultural population was only $5 \%$ (CBS, 1993).

5 In 1991, southern Dalmatia had 44\% active population, 15\% with personal income, and $41 \%$ were dependent, while the labour force participation rate was $64 \%$ (CBS, 1994). 
Tab. 6 Composition of the population of Mljet by economic activity and composition of the working population by the sector of activity in the 1961-201 period

\begin{tabular}{|c|c|c|c|c|c|c|c|}
\hline \multirow[b]{2}{*}{ Year } & \multicolumn{3}{|c|}{ Economic activity (\%) } & \multicolumn{3}{|c|}{ Sector of employed persons (\%) } & \multirow{2}{*}{$\begin{array}{l}\text { Labour } \\
\text { force par- } \\
\text { ticipation } \\
\text { rate }(\%)\end{array}$} \\
\hline & Active & $\begin{array}{l}\text { With } \\
\text { income }\end{array}$ & $\begin{array}{c}\text { Depen- } \\
\text { dent }\end{array}$ & Primary & Secondary & Tertiary & \\
\hline 1961 & 50.7 & 2.1 & 47.2 & 81.4 & 5.8 & 12.8 & 81.4 \\
\hline 1971 & 39.1 & 10.9 & 50.1 & 71.6 & 6.4 & 22.1 & 61.5 \\
\hline 1981 & 29.1 & 22.0 & 48.9 & - & - & - & 48.8 \\
\hline 1991 & $33 \cdot 9$ & 26.6 & 39.6 & 14.6 & 2.8 & 82.6 & 58.0 \\
\hline 2001 & 30.6 & 35.0 & $34 \cdot 4$ & 7.8 & 6.2 & 86.0 & 55.5 \\
\hline 2011 & 39.4 & 37.4 & 23.2 & $3 \cdot 3$ & 11.9 & 84.8 & 62.2 \\
\hline
\end{tabular}

Sources: FBS (1965; 1972; RBS (1983); CBS (1994; 2003)

The analysed processes continued on Mljet with lower intensity after the War and the recovery of tourism. The further decrease in agriculture (3\% in 2011) is associated with advanced population ageing and growing orientation towards tourism, which has all the characteristics of a monoculture ( $85 \%$ of the population worked in services in 2011) (Tab. 6). Southern Dalmatia, in contrast, has a more diversified composition of active population, due to its more complex economy-in 2011, $7 \%$ worked in the primary sector, $15 \%$ in the secondary sector, and $78 \%$ in services (CBS, 2013).

Mljet still belongs to the group of less developed regions with lower economic activity and fewer jobs, expressed depopulation and population ageing, lower educational levels and lack of initiatives for further development. In 2011, the island had the lowest share of active population (39\%) and one of the lowest labour force participation rates in southern Dalmatia $(62 \%)$, while the share of people with personal income was high $(37 \%)^{6}$. However, lower activity rates hide the level of real employment, as a significant part of the population with income work occasionally or seasonally in tourism.

The analysis revealed that in the period of socio-economic transformation of the island, tourism absorbed a part of the population that had left agriculture and that would otherwise have left the island. However, as is the case with educational level, it is not possible to draw a direct connec-

6 In 2011, the activity rate in southern Dalmatia was $51 \%$, the labour participation rate was $65 \%$, and the share of persons with income was $28 \%$ (CBS, 2013). 
tion between the level of tourism development and changes in the level of economic activity and its structure. The relation between tourism development and economic activity shows certain profiling only when a region reaches higher level of tourism development that starts to dominate among economic activities.

\section{Social pressure of tourism}

Besides contributing to socio-economic development, tourism generates a certain pressure on the area and the community in which takes place. This section aims to evaluate the social pressure of tourism on Mljet using the tourism function index and tourism intensity.

Near beginning of the investigated period (in 1966), the tourism intensity score of 81.7 on Mljet could not be considered to be pressure at all; furthermore, it represented a desirable alternative to the dominant agriculture (Tab. 7). Contemporary southern Dalmatia records considerable pressure of tourism (353.7), generated mostly by the Dubrovnik Littoral, and accompanied by a few small areas with high pressure (Mljet National Park, the bearer of tourism on the island, reached 420.7 arrivals per 100 inhabitants) (FBS, 1965; 1972; RBS, 1967).

Pressure of tourism in the late 1960 s and in the 1970 gradually increased along with the opening of new accommodation units (particularly a hotel in Pomena) and growth of tourism, and reached 221.4 arrivals and 68.2 beds per 100 inhabitants in 1976 (Tab. 7). Tourism was still limited to the Park, which had one hotel, one camp, and a few accommodation units in private households generating very high pressure (1,018.8 arrivals and 300.6 beds per 100 inhabitants). Outside the Park, only Sobra recorded modest tourism development. However, it is important to note that the island's small population is partially responsible for the high pressure of tourism in the whole period, as it has to handle a relatively large tourism supply and demand.

The island reached peak pressure in 1986 with 793.3 arrivals and 89.7 beds per 100 inhabitants, which was not much different from the regional average (846.6 and 61.1, respectively) (RBS, 1982; 1987; CBS, 1994). However, Mljet National Park recorded one of the highest pressures in southern Dalmatia $(3,422.9$ arrivals and 322.0 beds per 100 inhabitants), which was heavily contributed to by day-trippers visitors from Pelješac, Korčula, and Dubrovnik. 
Tab. 7 Indicators of social pressure of tourism on Mljet in the 1966-2016 period, by groups of settlements

\begin{tabular}{ccccccccc} 
& \multicolumn{3}{c}{ Tourism function index } & \multicolumn{5}{c}{ Tourism intensity } \\
\cline { 2 - 9 } Year & Mljet & $\begin{array}{c}\text { Mljet } \\
\text { National } \\
\text { Park }\end{array}$ & Coastal & Interior & Mljet & $\begin{array}{c}\text { Mljet } \\
\text { National } \\
\text { Park }\end{array}$ & Coastal & Interior \\
\hline 1966 & - & - & - & - & 81.7 & 420.7 & 0.0 & 0.0 \\
\hline 1971 & - & - & - & - & 134.4 & 675.7 & 0.0 & 0.0 \\
\hline 1976 & 68.2 & 300.6 & 54.3 & 0.0 & 221.4 & $1,018.8$ & 189.1 & 3.3 \\
\hline 1981 & 69.8 & 266.3 & 63.6 & 6.2 & 386.4 & $1,713.5$ & 162.9 & 11.0 \\
\hline 1986 & 89.7 & 322.0 & 71.3 & 0.0 & 793.3 & $3,422.9$ & 241.5 & 0.0 \\
\hline 1991 & 35.2 & 123.9 & 0.0 & 0.0 & 55.4 & 218.6 & 0.0 & 0.0 \\
\hline 1996 & 60.4 & 212.0 & 0.0 & 0.0 & 274.4 & 964.2 & 0.0 & 0.0 \\
\hline 2001 & 113.4 & 212.9 & 51.9 & 82.6 & 704.5 & $2,073.2$ & 147.2 & 163.0 \\
\hline 2006 & 147.4 & 246.8 & 228.3 & 39.0 & $1,323.8$ & $3,464.0$ & $1,000.0$ & 251.5 \\
\hline 2011 & 138.5 & 223.7 & 171.9 & 51.6 & $1,339.5$ & $3,176.9$ & $1,122.8$ & 299.9 \\
\hline 2016 & 212.3 & 298.3 & 285.9 & 64.4 & $2,370.2$ & $4,794.6$ & $2,844.3$ & 259.6 \\
\hline
\end{tabular}

Sources: FBS (1965; 1972); RBS (1967; 1972; 1977; 1982; 1983; 1987); CBS (1992; 1994; 1997; 2002; 2003; 2007b; 2012; 2013; 2017)

Rather high pressure of tourism in some small tourist resorts with more complex accommodation structures (e.g. Mljet National Park) represented one of many reasons behind the tourism decline that followed. Tourism in Croatia in the late 198 os suffered from various internal weaknesses and external factors, particularly shifting tourist preferences and stronger competition from tourism destinations in other countries. On the internal side, tourism arrivals and overnight stays exceeded the capacities of local communities, infrastructure, and workforce in resorts, which started to cause negative effects in the summer season and damaged the tourism experience. Therefore, after 1986, tourism entered a stage of decline (See: Šulc, 2016; 2017); accompanied by the War, this prevented tourists from visiting Croatia. Tourism intensity decreased more rapidly than the tourism function index, indicating that accommodation capacities were still available but visitors stopped coming.

Intensive recovery of tourism in the late 1990s again increased the pressure on the island, accompanied by growing pressure on coastal and 
interior settlements outside the Park, generated by the diffusion of tourism. In 2001, tourism intensity almost reached the pre-war level (704.5), while the tourism function index largely exceeded the pre-war maximum (113.4). The growing pressure on Mljet was much more rapid than in the broader area of southern Dalmatia (458.6 and 44.0, respectively), but in both areas its intensification was associated with the increase of accommodation capacity in private households (CBS, 2002; 2003).

Instead of medium and large hotels, whose location and design were carefully planned to fit the cultural landscape, numerous new private objects, often unplanned, illegal, without required permissions, were built outside construction areas of settlements and not adjusted to the environment, which led to the spread of urbanised areas in the most attractive coastal areas. This blocked these areas from being used for other, more productive (tourism) functions. At the same time, the classic "sun and sea" tourism product remained the core of the tourism supply, generating growing pressure of tourism on infrastructure, settlements, environment, and local communities in the short summer season.

Despite the analysed processes, the pressure of tourism on Mljet increased continuously in the 2000 s and 2010 s and exceeded the pre-war maximums by 2 or 3 times. With $2,370.2$ arrivals and 212.3 beds per 100 inhabitants in 2016, Mljet became one of the most pressured areas in southern Dalmatia, largely exceeding regional averages $(1,302.8$ and 69.8 , respectively) (CBS, 2003; 2013; 2017). It is important to note that, apart from registered tourism, an additional $30 \%$ of tourist arrivals and overnight stays goes unregistered (according to tourism stakeholders) (Šulc, 2016). Although it may seem that spatial diffusion of tourism has distributed its pressure equally throughout the island, the high level of pressure is still unacceptable for an area with preserved natural environment, and particularly for a national park, which requires a strict and sustainable development regime for tourism.

The pressure is particularly high in very small coastal settlements, with low levels accommodation and inhabitants, which experience rather intensive private tourism construction, often lacking basic communal and tourism infrastructure. However, it is important to stress that high pressure is often the consequence of small absolute figures and cannot be compared to large tourist resorts, meaning that this has to be taken with caution in the analysis. It is indicative that in 9 out of 14 settlements the number of tourist beds exceeds the population, e.g. in Pomena by 11 times over and 
in Saplunara by sixfold. Apart from registered tourists, the island's coastal settlements are additionally pressured by rather intensive nautical tourism, which is not officially registered. However, due to the low level of development of other economic activities, the local population does not perceive tourism as a pressure or a burden and welcomes its further development. It is important to emphasise that the main problem is not the number of beds themselves but the fact that the peak development of tourism on Mljet is limited to "sun and sea", which fails to fully realise the island's potential, and causes an intensive, often deteriorating, physical transformation of tourism areas.

\section{Conclusion}

All the goals defined in the chapter's introduction have been fulfilled and a deeper insight into the relationship between tourism and demographic and socio-economic processes in protected areas in the Croatian Littoral was provided. It was confirmed that it is not possible to draw a direct link between tourism development and demographic changes because both processes are influenced by various factors (See: Zupanc et al., 2000). As in other remote and/or rural island or peninsular areas, development of tourism occurred under the conditions of a disrupted age-sex composition (See: Nejašmić, 1998; 1999; 2013), which was partially responsible for the lower level/quality of the tourism supply and did not have the power to pull new migrants from the mainland (Šulc, 2016). Nevertheless, even extensively developed tourism gave part of the local population the opportunity to earn more for a living and managed to keep them on the island. Therefore, tourism can be considered to be the most important factor of the socio-economic transformation of the island, particularly in terms of work and economic activity.

The analysis also revealed very high social pressure of tourism on a small population, much higher than in some developed tourism areas (e.g. Dubrovnik). Although the local population welcomes further development due to its beneficial economic effects, the current pressure on the environment is great, and this makes the local economy extremely sensitive to any oscillations in the tourism market. As the pressure is the highest in the summer and generated largely by tourism in private households with a low occupancy rate, future tourism development should focus on the development of small hotels and the creation of a more complex tourism supply, aimed to prolong the tourist season. 
Experiences of developed tourism destinations in the Mediterranean area confirmed that, in cases of similar accommodation capacities, destinations with more beds in hotels have much higher numbers of tourist arrivals and overnight stays than those with high shares of accomodation in private households. Furthermore, as Mljet National Park is the most pressured area, priority should be given to preserving the environment and developing non-invasive tourism activities that would valorise it. If the paradigm of tourism development on Mljet remains the same, the island could face degradation of its natural environment and cultural landscape, as well as lack of sufficient workforce and the need to import a larger number of workers from the mainland.

\section{References}

Andriotis, K., 2006: Hosts, Guests and Politics: Coastal Resorts Morphological Change, Annals of Tourism Research 33 (4), 1079-1098, DOI: 10.1016/j. annals.2006.04.003.

Black, A., 1996: Negotiating the tourist gaze: The example of Malta, in: Coping with Tourists: European Reactions to Mass Tourism (ed. Boissevain, J.), Berghahn Books, Oxford, 112-142.

Boissevain, J., Theuma, N., 1998: Contested space. Planners, tourists, developers and environmentalists in Malta, in: Anthropological Perspectives on Local Development (eds. Abram, S., Waldren, J.), Routledge, London, 96-119.

Bramwell, B., 2003: Mass Tourism, Diversification and Sustainability in Southern Europe's Coastal Regions, in: Coastal Mass Tourism: Diversification and Sustainable Development in Southern Europe (ed. Bramwell, B.):, Channel View Publications, Clevedon, 1-31.

Butler, R., 1980: The Concept of a Tourist Area Cycle of Evolution: Implications for Management of Resources, Canadian Geographer 24, 5-12.

Chapman, A., Speake, J., 2011: Regeneration in a mass-tourism resort: The changing fortunes of Bugibba, Malta, Tourism Management 32 (3), 482491, DOI: 10.1016/j.tourman.2010.03.016.

Doxey, G., 1975: A causation theory of visitor-resident irritants: methodology and research inferences in the impact of tourism, in: Sixth annual conference proceedings of the Travel Research Association, San Diego, 195-198. 
Faričić, J., Graovac, V., Čuka, A., 2010: Croatian Small Islands - Residential and/or Leisure Area, Geoadria 15 (1), 145-185, DOI: doi.org/10.15291/ geoadria.548.

Garay, L., Cànoves, G., 2011: Life Cycles, Stages and Tourism History. The Catalonia (Spain) Experience, Annals of Tourism Research 38 (2), 651-671., DOI: 10.1016/j.annals.2010.12.006.

Ioannides, D., 2001: The dynamics and effects of tourism evolution in Cyprus, in: Mediterranean Tourism: Facets of socioeconomic development and cultural change (eds. Apostolopoulos, Y. et. al.), Routledge, London - New York, 129-145.

Lajić, I., 2006: Kvarnerski otoci - demografski razvoj i povijesne mijene, Institut za migracije i narodnosti, Zagreb.

Lajić, I., Mišetić, R., 2006: Otočni logaritam. Aktualno stanje i suvremeni demografski procesi na jadranskim otocima, Institut za migracije i narodnosti, Ministarstvo mora, turizma, prometa i razvitka, Zagreb.

Nejašmić, I., 1991: Depopulacija u Hrvatskoj: korijeni, stanje, izgledi, Globus nakladni zavod, Zagreb.

Nejašmić, I., 1992: Promjene u dobno-spolnom sastavu stanovništva istočnojadranskog otočja, Acta Geographica Croatica 27, 15-34.

Nejašmić, I., 1998: Croatian islands - the role of demographic features in tourism development, Croatian Geographical Bulletin 6o, 17-30.

Nejašmić, I., 1999: Uloga turizma u diferenciranom demografskom razvitku otočnih naselja: primjer srednjodalmatinskog otočja, Croatian Geographical Bulletin 69, 37-52.

Nejašmić, I., 2005: Demogeografija: stanovništvo u prostornim odnosima i procesima, Školska knjiga, Zagreb.

Nejašmić, I., 2013: Demografsko starenje na hrvatskim otocima, Migracijske i etničke teme 29 (2), 141-168, DOI: 10.11567/met.29.2.2.

Nejašmić, I., Mišetić, R., 2006: Population of the Vis Island, Geoadria 11 (2), 283-309, DOI: 10.15291/geoadria.111.

Nejašmić, I., Toskić, A., Mišetić, R., 2009: Demografski resursi Republike Hrvatske: Sintetični pokazatelji za županije, gradove i općine, Hrvatsko geografsko društvo, Zagreb.

Pulina, M., Biagi, B., 2006: Regional public policy and tourism life cycle: the case of Sardinia, 46th Congress of the European Regional Science Association University of Thessaly, Volos. 
Starc, N., 2001: Managing island development: the Croatian case, Sociologija sela $39(1-4), 15-36$.

Stražičić, N., 1969: Otok Mljet. Regionalna izdvojenost i socijalno-geografski problemi, Acta eographica Croatica 8, 119-159.

Šubić, N., 1995: Turizam Mljeta jučer i sutra, in: Mljet: zbornik radova sa simpozija Prirodne značajke i društvena valorizacija otoka Mljeta (eds. Durbešić, P, Benović, A.), 691-698.

Šulc, I., 2016: Models of Tourism Development in South Dalmatia, Croatia, Doctoral Thesis, University of Zagreb, Faculty of Science, Zagreb (in Croatian).

Šulc, I., 2017: Distorted life cycle on post-socialist Adriatic islands: Using the example of Mljet, Croatia, Acta Turistica 29 (1), 33-73, DOI: 10.22598/ at/2017.29.1.33.

Šulc, I., 2019: Environmental Impacts of Tourism on the Eastern Adriatic Coast - The Case of South Dalmatia, Croatia, in: Atti del XXXII Congresso Geografico Italiano, 2777-2789.

Šulc, I., Valjak, V., 2012: Protected Areas as a Factor in Sustainable Development of the Croatian Islands - the Example of Mljet Island, Croatian Geographical Bulletin 74 (1), 161-185 (in Croatian), DOI: 10.21861/ HGG.2012.74.01.09.

Šulc, I., Zlatić, M., 2014: Demographic Changes on Small Adriatic Islands: The Case Study of Ilovik, Croatia, Sociology and Space 52 (1), 3-22, DOI: 10.5673/sip.52.1.1.

Zhong, L., Deng, J., Xiang, B., 2008: Tourism development and tourism area life-cycle model: A case study of Zhangjiajie National Forest Park, China, Tourism Management 29 (5), 841-856, DOI: 10.1016/j.tourman.2007.10.002.

Zupanc, I., Opačić, V. T., Nejašmić, I., 200o: Utjecaj turizma na demografska kretanja hrvatskih otoka, Acta Geographica Croatica 35, 133-146.

\section{Sources}

Croatian Bureau of Statistics (CBS), 1965-2012: Livebirths and Deaths 1964-2011, by settlements, CD-ROM, Zagreb.

Croatian Bureau of Statistics (CBS), 1992: Tourism Turnover in Seaside Municipalities in 1991, Statistical Report, Zagreb.

Croatian Bureau of Statistics (CBS), 1994: Census of Population, Households and Dwellings in 1991, Documentation 881-888, Zagreb. 
Croatian Bureau of Statistics (CBS), 1997: Tourism Turnover in Seaside Towns and Municipalities in 1996, Statistical Report, Zagreb.

Croatian Bureau of Statistics (CBS), 2002: Tourism Turnover in Seaside Towns and Municipalities in 2001, Statistical Report, Zagreb.

Croatian Bureau of Statistics (CBS), 2003: Census of Population, Households and Dwellings $31^{\text {st }}$ March 20o1, CD-ROM, Zagreb.

Croatian Bureau of Statistics (CBS), 2007a: Statistical Classification of Economic Activities, http://www.ips-servis.hr/files/warehouse/2014/ nkd2007.pdf (08. 09. 2019)

Croatian Bureau of Statistics (CBS), 2007b: Tourism in Seaside Towns and Municipalities in 2006, Statistical Report, Zagreb.

Croatian Bureau of Statistics (CBS), 2012: Tourism in 2011, Internal Database by Settlements, Zagreb.

Croatian Bureau of Statistics (CBS), 2013: Census of Population, Households and Dwellings in 2011, www.dzs.hr (08. 09. 2019)

Croatian Bureau of Statistics (CBS), 2017: Tourism in Seaside Towns and Municipalities in 2016, Statistical Report, Zagreb.

Croatian Geodetic Administry (CGA), 2016: Central Registry of Spatial Units in the Republic of Croatia, GIS shapefiles.

Federal Bureau of Statistics (FBS), 1965: Census of Population in 1961, Book XIXV, Belgrade.

Federal Bureau of Statistics (FBS), 1972: Census of Population and Dwellings in 1971, Belgrade.

Mljet Tourist Board, 2019: Accommodation, http://www.mljet. $\mathrm{hr} /$ ? $=$ hr\&ispis $=$ staticna\&id $=5$ (09. 09. 2019)

Pansion Jezero, 2015: Tko smo mi?, http://free-zg.t-com.hr/tpudic/Hrv/kucahist. htm (o8. 12. 2015)

Republic Bureau of Statistics (RBS), 1967: Tourism Turnover in Seaside Resorts I-XII 1966, Documentation, Zagreb.

Republic Bureau of Statistics (RBS), 1972: Tourism Turnover in Seaside Resorts in 1971, Documentation, Zagreb.

Republic Bureau of Statistics (RBS), 1977: Tourism Turnover in Seaside Municipalities in 1976, Documentation, Zagreb.

Republic Bureau of Statistics (RBS), 1982: Tourism Turnover in Seaside Municipalities in 1981, Documentation, Zagreb. 
Republic Bureau of Statistics (RBS), 1983: Census of Population, Households and Dwellings $31^{\text {st }}$ March 1981, Zagreb.

Republic Bureau of Statistics (RBS), 1987: Tourism Turnover in Seaside Municipalities in 1986, Documentation, Zagreb. 


\section{Chapter 5 \\ The importance of protected areas \\ on the Slovenian coast for tourism \\ and how they could be impacted \\ by climate change}

Valentina Brečko Grubar, Nataša Kolega, Gregor Kovačič

\section{Abstract}

In Slovenia, the coastal area contains four large-scale protected areas. Sečovlje Salina Nature Park, Strunjan Landscape Park, Debeli Rtič Landscape Park, and Škocjanski zatok Nature Reserve are "islands of nature" in the largely-urbanised coastal strip, which have also become important sites for leisure and tourism activities. In recent years, the number of visitors (both individuals and groups) has been increasing and has already exceeded the carrying capacity of the environment. The urbanisation and economic use of the coastal strip exerts pressures on its constituent protected areas, which are also increasingly threatened by climate change. According to projections, climate change will bring higher temperatures, less precipitation, lower river discharge, and an increased number of extreme weather phenomena, which will affect habitats and biodiversity in protected areas. However, the greatest concern is related to the anticipated rise in sea level, which will cause frequent or permanent flooding, as well as the loss of existing habitats and sites for leisure and tourism activities.

Key words: landscape park, nature reserve, tourism visitation, climate change, sea level rise, flooding, geography, Slovenia 


\section{Introduction}

Slovenia's part of the coastal strip of the Gulf of Trieste lies between Zaliv svetega Jerneja (St. Bartholomew's Bay) at the border with Italy and the Dragonja River at the border with Croatia, and is approximately $48 \mathrm{~km}$ long (Kolega, 2015). A round two-thirds of the strip consists of a high, abrasion coast with active and fossil cliffs of different heights. The lower alluvial parts of the Slovenian coast, which were shaped by fluvial sediments that the Rižana, Badaševica, Dragonja, and Drnica rivers washed into the sea over time, were transformed into saltworks during Roman times. Following the gradual cessation of salt-extraction at the end of the $19^{\text {th }}$ century and the beginning of the $2 \mathrm{O}^{\text {th }}$ century, these areas were retransformed into salty or brackish coastal wetlands.

A large part of the salt-extraction areas in the immediate vicinity of the towns of Koper, Izola, and Portorož has been hydrologically improved, drained, and converted into agricultural land; more recently, it has also been largely built-up. The expansion of the Port of Koper, dating back to the 1950s, created another coastal wetland - Škocjanski zatok. In the past, the port areas were progressively expanded from Koper across Škocjanski zaliv (Škocjan Bay), and gradually a "barrier of land" was formed, turning the bay into a closed lagoon (Fig. 1), where materials from the deepening of the port basins, as well as waste and wastewater, were deposited. Thanks to DOPPS-Birdlife Slovenia, the area has avoided complete degradation from drainage and dumping (Mozetič and Šalaja, 2002). During the 199os, the areas of the Sečovlje Saltpans, the Strunjan Saltpans, and Škocjanski zatok were declared protected areas, followed by the Debeli Rtič area in 2018.

Each year, these four coastal Slovenian municipalities are visited by more than 700,000 tourists, who generate more than two million overnight stays. The majority of the guests and overnight stays are concentrated along the narrow coastal strip, i.e. in coastal towns, with roughly two-thirds of all overnight stays being recorded in the three summer months. From June to the end of August 2019, the settlements Portorož and Piran alone recorded more than half a million overnight stays, while Koper had around 160,000 and Izola around 11,00o. By the end of 2019, 71 cruise ships had stopped in Koper, with more than 110,00o passengers aboard (Regional Obala, 2019b). In addition to local beaches and swimming spots, tourists visit points of interest in the close vicinity, including the large-scale protected areas that are the subject of this chapter. Thus, the maintenance of existing conditions, 


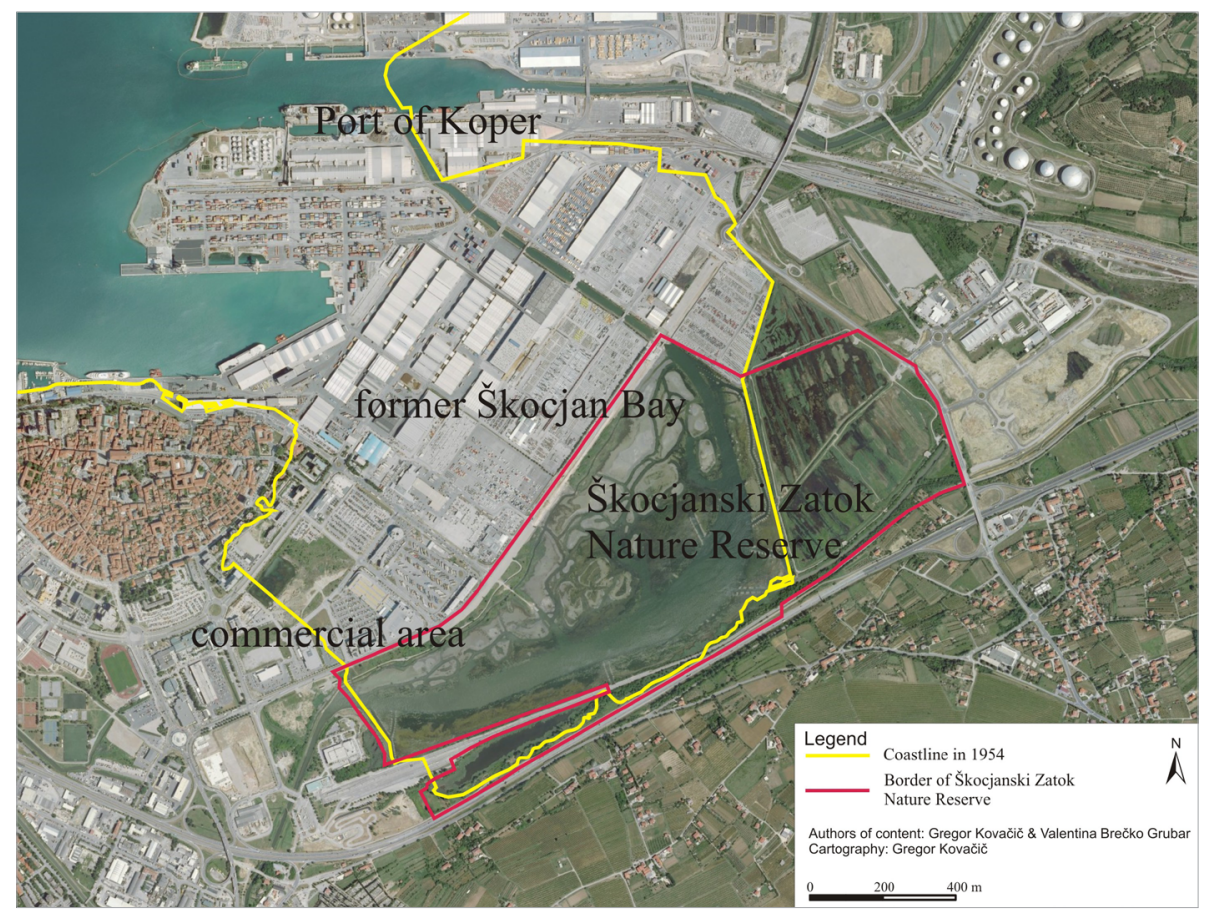

Fig. I Former Škocjan Bay and Škocjanski zatok Nature Reserve

Source: Surveying and Mapping Authority of the Republic of Slovenia, 2009

and the planning and sustainable management of these protected areas are not only vital for the preservation of habitats and biodiversity, but also for tourism and the quality of life of the local population. While restrictions on land use and other human activity, as laid down by protection regimes enacted by the Nature Conservation Act (1999), are aimed to ensure the longterm existence of the protected areas, they, unfortunately, cannot prevent the negative consequences of the degradation of the global environment and the impact of climate change.

The preserved natural areas contribute significantly to the quality of the environment, they have become leisure sites for local people, and have increasing educational importance; they also offer guided tours and various other activities (Brečko Grubar and Kovačič, 2014). They are also increasingly included in the tourism supply, and the existing number of visitors has already exceeded the carrying capacity of the environment and threatens nature protection imperatives. These protected areas are also exposed to pressures from economic activities that are carried out in their 
surroundings, both on land and offshore, and are increasingly threatened by the changing climate.

Climate change is projected to bring about a rise in sea level, which would cause either frequent (during the tides) or permanent flooding, and the loss of important habitats and tourism sites. Climate change typically involves an increase in temperatures and evapotranspiration, a decrease in precipitation and runoff, more frequent extreme precipitation events, and long-lasting dry periods. The protected areas that are the subject of this chapter will almost certainly experience considerable changes in wet/dry dynamics and more frequent heavy flooding, and also be affected by higher temperatures and salinity levels.

\section{Large-scale protected areas on the Slovenian coast and their importance for tourism}

Despite the fact that around one-third (30\%) of the coastline lies within protected areas, today around four-fifths (81\%) of the coastline has been anthropogenically transformed (Kolega, 2015), and protected areas represent the only (partially) preserved natural environments with a high ecosystem value. The coastline contains four large-scale protected areas. Under the Nature Conservation Act (1999), these are three landscape parks (Sečovlje Salina Nature Park, Strunjan Landscape Park, and Debeli Rtič Landscape Park), which broadly correspond to IUCN Category V - Protected Landscape, and Škocjanski zatok Nature Reserve, which is classified into Category Ib - Wilderness Area (Sovinc, 2011). The narrowest coastal strip also comprises several natural monuments, sites of valuable natural features, ecologically important areas, and Natura 2000 sites. Together, the large-scale protected areas cover an area of more than $16 \mathrm{~km}^{2}$.

\section{Sečovlje Salina Nature Park}

Sečovlje Salina Nature Park (also referred to as the Sečovlje Saltpans) extends over an area of around 750 ha, of which saltpans cover 600 ha, between the Seča Peninsula and Jernejev kanal (Bartholomew's Channel) on one side and the border with Croatia on the other (Fig. 2). In 2002, the company Soline Pridelava soli d.o.o. was selected as the manager of the Park. One part of the Park consists of the area of the abandoned Fontanigge Saltworks, which is maintained for the purposes of preserving habitat types and other ecosystem values, while the other part of the Park comprises the 
active Lera Saltworks, where salt is produced in a traditional manner and tourism activities, e.g. dedicated and guided tours and events, take place. In addition, at the recently-opened Lepa Vida Thalasso Spa guests can enjoy therapy sessions with brine, salt, and salt-pan mud.

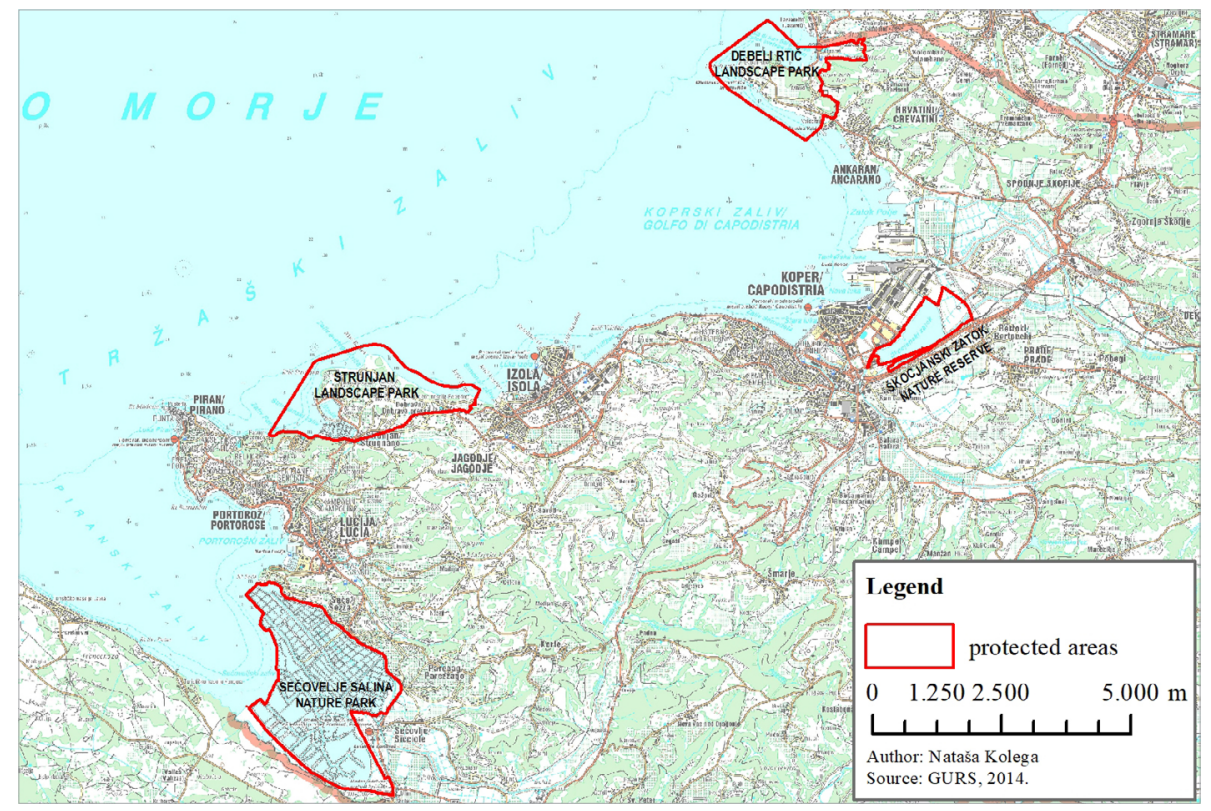

Fig. 2 Large-scale protected areas on the Slovenian coast Source: Surveying and Mapping Authority of the Republic of Slovenia, 2014

The Sečovlje Saltpans are a permanent or temporary home to a large number of rare and endangered bird species, as well as other species of flora and fauna, for which they are of great national and international importance. They were designated as wetlands of international importance under the Ramsar Convention (Ramsar sites) in 1993. The area in question consists of three conservation zones:

(1) the Fontanigge Saltworks, which were abandoned in the 1960s;

(2) the still active Lera Saltworks; and

(3) the agricultural land in the hinterland of the saltpans (Turk, 2012).

Within the protected area visitors can take part in activities in a saltpan house renovated as a museum facility, and in areas intended for multimedia presentations, occasional exhibitions, the sale of products made from 
salt, souvenirs, and similar materials. There are also $9 \mathrm{~km}$ of groomed walking and cycling trails, a demonstration salt field, and information points. Apart from sightseeing, the park hosts various educational and recreational programmes, as well as social activities (Sečovlje Salina Nature Park, 2019).

Visitation of the Sečovlje Saltpans has been high for some time, with evidence showing a significant increase in recent years. In 2010, 28,843 visits were recorded (Sovinc, 2011), while in 2018 the number increased to 51,294 , of which 31,402 were individual visits and 19,892 were group visits. Although in 2018 the number of visitors decreased by 2,915 compared to the previous year, it still exceeded the estimated carrying capacity of the environment, which is 50,000 visitors per year (Sečovlje Salina Nature Park, 2019). Apart from groups of primary and secondary school students, Sečovlje Salina Nature Park is visited in large numbers by groups of visitors on organised day trips, and passengers of cruise ships arriving at the port Koper. Among individual visitors, most stay in hotels or in individual accommodation.

In Lucija, there is also a camping site and the largest marina on the Slovenian coast, while in the wider surrounding area there are many private holiday homes, which are mostly occupied over the summer months. The abandoned Fontanigge Saltworks are visited by both domestic and foreign visitors and are also accessible via a groomed cycling trail; the area is popular among visitors for its natural beauty and lack of an entrance fee. In addition, Sečovlje Salina Nature Park can be accessed by sea, as there is a nearby harbour.

\section{Strunjan Landscape Park}

Strunjan Landscape Park covers an area of 428 ha located between Izola and Piran (Fig. 2). It encompasses a brackish lagoon with preserved saltpans (Stjuža Nature Reserve), a steep cliff and coastline (Strunjan Nature Reserve), and the cultural landscape in the hinterland. Together, the two nature reserves cover 163 ha, and were declared protected areas in 1989. The Decree on Strunjan Landscape Park was adopted in 2004, and the manager of the protected area was designated in 2008 (Strunjan Landscape Park, 2019). The park area encompasses part of the settlement Strunjan, agricultural areas, the Krka Strunjan Spa complex with accommodation facilities, and a natural swimming spot with associated infrastructure.

The Strunjanski polotok (Strunjan Peninsula) has largely retained its agrarian character. Arable areas on cultivated terraces are supported by 
stone walls, and there are preserved structures made of piled stones (without mortar), which have served as shelters or plant-watering catchments in the past. The area is known for artichoke and persimmon production (there is a traditional Persimmon Festival each year), as well as for the production of olives and other crops. Although the area is populated, it is a largely well-preserved natural environment with high landscape diversity and various habitat types. Development in the landscape park is oriented towards the promotion of sustainable forms of agriculture, ecologically friendly tourism and recreation, cultural heritage protection, implementation of traditional salt production, and the use of ecologically-friendly practices in natural resources management (Jurinčič and Popič, 2009).

Recently, the regulation of tourism development has been at the forefront, as visitation to the park is increasing. To this end, additional groomed and marked walking and cycling trails have been made, an info centre set up, guided tours offered, quays and bollards set up, etc. (Strunjan Landscape Park, 2019). The area is heavily burdened by tourism during the summer months, when longer-term guests are joined by numerous day-trippers and many passing vessels in the bay. Last year, 2,817 people attended guided tours in Strunjan Landscape Park (Makovac, 2019), which, however, represented only a small share of all visitors. Within the park, there are hotels, a camping site, and private accommodation; guests are able to take part in walking, cycling, and other sport activities (tennis, beach volleyball, swimming). The protected area is well-connected with the wider surrounding area, including cycling (Parenzana) and hiking trails, and with Izola, Pacug and Fiesa, where there are also various accommodation facilities and tourist visitation is on the rise.

\section{Škocjanski zatok Nature Reserve}

The Škocjanski zatok Nature Reserve encompasses 120.7 ha of brackish and salty marshland, situated on the edge of Koper (Fig. 2). It lies between shopping centres in the south-eastern part of Koper, the coastal express road with connecting urban roads, and the railway line. Following its rehabilitation, the area was protected as a nature reserve (1998), and its management was taken over by DOPPS-Birdlife Slovenia in 1999, which was followed by several years of renaturation. As a whole, Škocjanski zatok, with its salty, brackish, and freshwater habitats, has 245 recorded bird species, a variety of other species of fauna, and vast tidal marshes with halophytes; it is a natural asset and an ecologically-important area, as well as a Natura 2000 site 
(Škocjanski zatok Nature Reserve, 2019). Among the reserve's many features are a nature trail with wildlife observation blinds and information boards, an info centre, guided tours, and activities involving Camargue horses, which has led to it becoming a popular and highly visited site.

In a survey conducted in 2011, it was found that Škocjanski zatok plays an important role as a daily recreation and leisure time area for the residents of Koper, and that the most important motivation among visitors is to relax in a peaceful natural environment (Brečko Grubar and Kovačič, 2011). In 2018, 7,401 people took part in guided visits to the nature reserve, while the total number visitors is estimated at over 40,000 (records are not kept of individual visits) (Lipej, 2019). Like the aforementioned protected areas, guided tours organised for groups of primary school students, secondary school students, and day-trippers prevail in Škocjanski zatok. Thanks to the successful renaturation and management of the wetlands, the nature reserve is also a destination for expert study tours, and our observations show that there is also an increasing number of tourists who visit the area by bicycle. The largest proportion of visits consists of locals pursuing recreational and leisure activities.

\section{Debeli Rtič Landscape Park}

Debeli Rtič Landscape Park was established in 2018 by an ordinance of the Municipality of Ankaran, which became its manager. The park extends over an area of 340 ha on the Ankaranski polotok (Ankaran Peninsula), between Zaliv svetega Jerneja at the border with Italy and Valdoltra Bay where the Valdoltra Orthopaedic Hospital is located (Fig. 2). Apart from a narrow coastal strip of land, it also comprises a 160 ha of coastline. The protected area boasts a variety of natural assets, such as cliffs, underwater reefs, an oak forest, a botanical garden near the Red Cross Slovenia Youth Health and Summer Resort, and beds of marine flowering plants. The area of the landscape park is also an ecologically important area and a Natura 2000 site.

The Park is divided into three conservation areas, with the two (stricter) conservation areas comprising a strip of land closer to the sea and a strip of coastal water, and the third conservation area (of a lesser level of protection) comprising the populated and agriculturally exploited ridge of the Peninsula (Debeli rtič Landscape Park, 2019). There are no data on the number of visitors, as the protected area is new and there are no guided tours. According to observations, the area is highly visited during the 
swimming season, when tourists staying in the camping site, hotels, youth health and summer resort, as well as in private accommodations, are joined by numerous swimmers from nearby Slovenian and Italian towns and villages. Tourists find the area of Debeli Rtič Landscape Park equally attractive throughout the remaining part of the year, because of its broad offerings in gastronomic and reacreational services, as well as its natural beauty.

\section{Consequences of anticipated climate change}

in the large-scale protected areas on the Slovenian coast

In Slovene Istria, climate change is most notably reflected in the statistically reliable trend of increasing annual air temperature recorded at the Portorož - Airport meteorological station during the 1961-2018 period, with a rate of $0.37^{\circ} \mathrm{C} /$ decade, while average annual peak temperature is increasing at a rate of $0.42{ }^{\circ} \mathrm{C} / \mathrm{dec}$ de. Increasing air temperatures are raising the level of energy in the atmosphere and contributing to increased evapotranspiration, which showed a long-term trend of increasing by $49 \mathrm{~mm} /$ decade in the area of Slovene Istria during the 1971-2010 period. Calculations show that during the 1961-2018 period the annual precipitation level was decreasing in statistically significant terms in the same area, at a rate of $32 \mathrm{~mm} / \mathrm{dec}-$ ade (Fig. 3).

The observed long-term changes in meteorological variables, the decreasing annual precipitation level, and the increasing annual evapotranspiration level affect runoff in Slovene Istria. The volume of water runoff into the sea is decreasing, which is demonstrated by a declining trend in the mean annual discharges of the Rižana River at the Kubed II gauging station during the 1966-2017 period, which, according to reliable calculations, were decreasing at a rate of $360 \mathrm{l} / \mathrm{s} /$ decade (Fig. 4).

It is not simple to assess the possible impacts of long-term reduction in the volume of water running through watercourses into the sea within the large-scale protected areas on the Slovenian coast. It can be assumed that the impact will be smallest in the area of Debeli Rtič Landscape Park, where there are only small streams with small catchments, which are largely regulated. However, since the area is agriculturally cultivated, reduced volumes of water in soil could pose a problem in terms of droughts occurring during the growing period of crops.

Since the coastal wetlands of Škocjanski zatok Nature Reserve, Sečovlje Salina Nature Park, and parts of Strunjan Landscape Park (the saltpans 


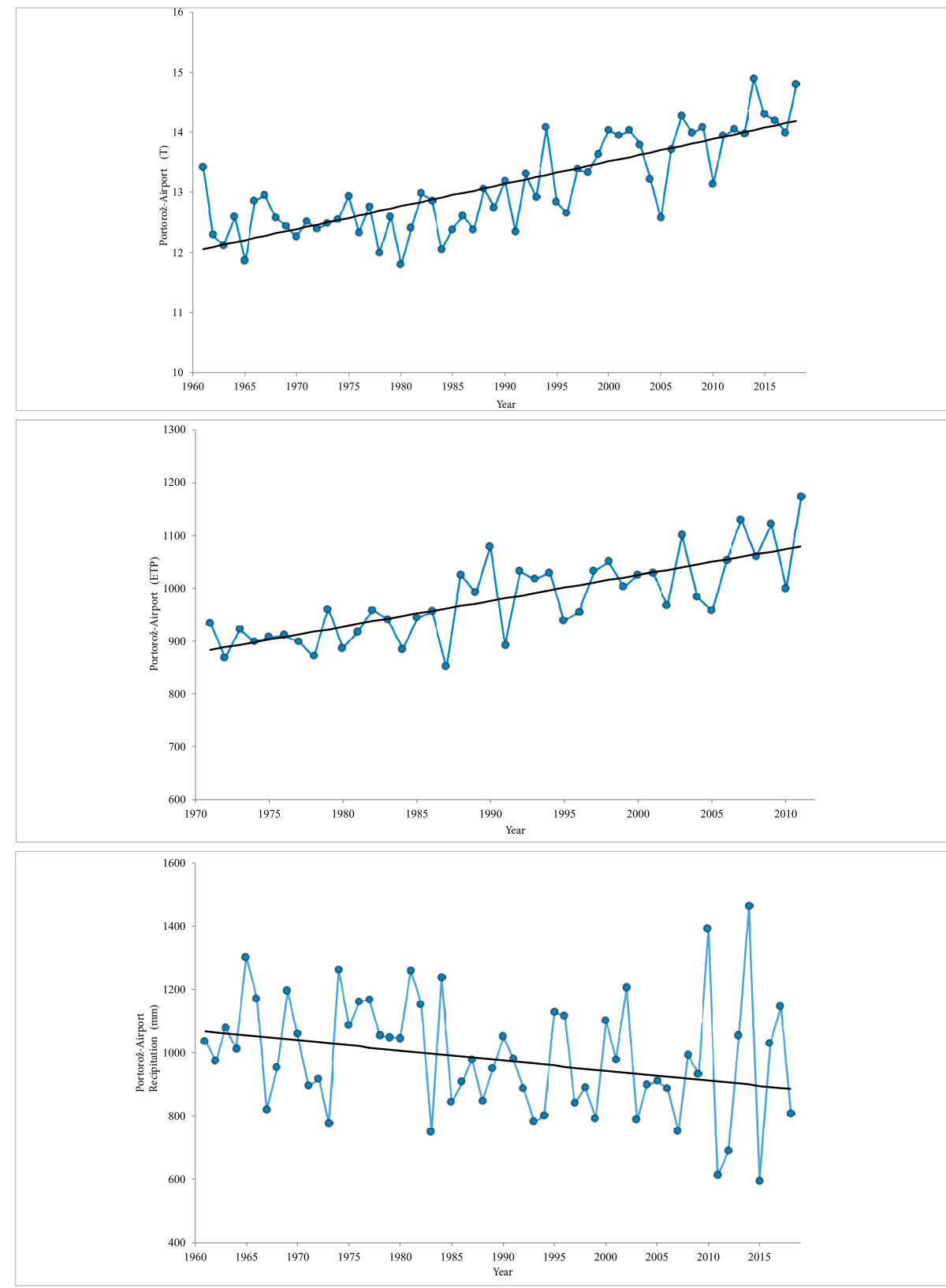

Fig. 3 Average annual values of meteorological variables at the Portorož - Airport meteorological station in the 1961-2018 (temperature and precipitation) and 1971-2010 (evapotranspiration) periods, with an indication of trends Source: Slovenian Environmental Agency, 2019c 


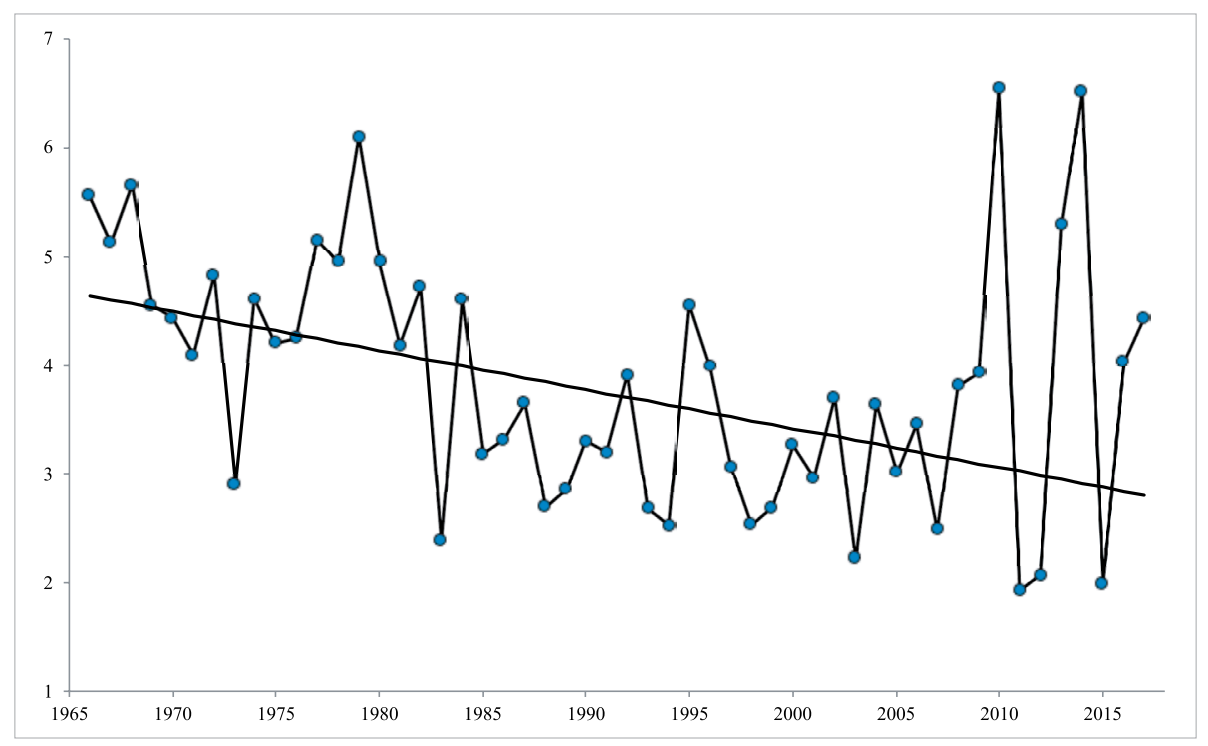

Fig. 4 Average annual discharge ( $\mathrm{m} 3 / \mathrm{s}$ ) of the Rižana River at the Kubed II gauging station during the 1966-2017 period, with an indication of a trend Source: Slovenian Environmental Agency, 2019b

and the lagoon) are dynamic areas of interaction between running surface waters and seawater, a long-term reduction in surface runoff in the area of Slovene Istria could also have an impact on the geomorphology of floodplains at the estuaries of the rivers that formed them. Smaller volumes of water available for runoff in the future could lead to a reduction in the capacity of watercourses to transport very fine sediments that are needed to build the aforementioned floodplains, i.e. the wetlands. This could, in turn, threaten the dynamic equilibrium of the sedimentation areas in question, and lead to a situation where the amount of sediments washed into (further) the sea is more intense than the amount of material deposited by rivers, which could lead to a reduction in the wetland area.

Given the global rise of air temperature and the related increase of energy in the atmosphere, the frequency of extreme weather eventsstorms-which cause short-lived and very intense discharges along watercourses, will increase. In such situations, the erosional power of watercourses increases sharply, which can have a negative impact on protected areas (i.e. the wetlands) in the form of flooding and increasing amounts of sediment being washed deep into the sea. This could, of course, negatively affect the future use of the protected areas for tourism purposes. 
Therefore, it is also necessary to consider possible scenarios in relation to the protection of protected areas and individual natural assets, and to provide appropriate long-term sustainable measures for the management thereof.

A specific case is the area of Škocjanski zatok Nature Reserve, which is filled with fresh water from an artificially excavated overflow channel (called Ara) of the Rižana River. The inflow of freshwater to the wetland area is vital to maintain the dynamics of the periodically flooded and dry areas of the reserve. Reduced volume of water in the Rižana River could also mean that there would not be enough water to properly flood the eastern part of the wetland, particularly in cases where spring discharges are significantly reduced. Since the areas of the wetland represent a retention area in the event of flooding, protecting human activities taking place in the surroundings, a certain threat to the area also comes from the rising frequency of extreme weather events (Lipej, 2019).

Climate change is also reflected in sea level rise, which is a global phenomenon. During strong high tides, which typically occur in the autumn/ winter period while there is either a full or new moon and with the sirocco wind pushing water towards the Gulf of Trieste, the sea level rises sharply and the sea overflows the lower-lying parts of the coast. Sea flooding occurs when the sea level rises $82 \mathrm{~cm}$ above the mean value. Normal flooding of the lowest-lying areas takes place a few times a year and does not cause damage. In the 1961-2015 period, there were 8 to 31 floods per year, and 482 floods during the whole period in question (Slovenian Environmental Agency, 2019d). Small-scale or large-scale sea flooding occurred before the tide gauge station in Koper was put into operation, and available sources show that the most exposed areas were the low-lying coastal zones at Sečovlje, Piran, and Strunjan (Kolega, 2005). Monitoring of sea levels in Slovenia reveals that in the last 50 years the sea level has risen by $10 \mathrm{~cm}$ and has been rising at a rate of $1.7 \mathrm{~mm}$ per year (Fig. 5), while in the last 20 years the rate has been even higher than the European and global averages (Regional Obala, 2019a). IPCC (Intergovernmental Panel on Climate Change) scientists estimate that sea levels will rise globally by 0.5 to $1 \mathrm{~m}$ by 2100 (Church et al., 2013).

Sea level rise is already being reflected in the introduction of non-native species characteristic of warm seas (Lipej and Kerma, 2012), and climate change will influence the development of terrestrial ecosystems over the long run. 


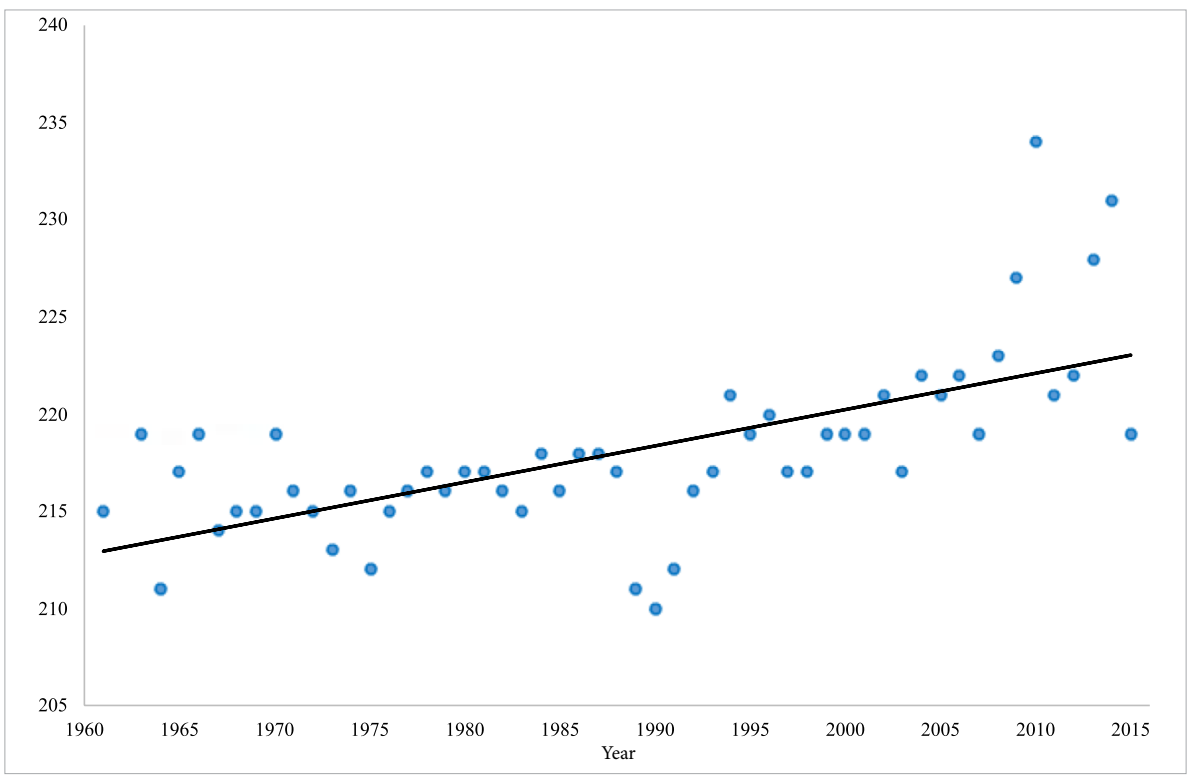

Fig. 5 Mean annual sea levels (cm) in Koper in the 196I-2015 period, with an indication of a trend

Source: Slovenian Environmental Agency, 2019a

With a sea level rise of $50 \mathrm{~cm}$, even slightly higher high tides $(+60 \mathrm{~cm})$ will cause flooding, and during strong high tides $(+115 \mathrm{~cm})$ the lowest-lying parts of the coast would be covered by approximately $80 \mathrm{~cm}$ of water, and around 700 ha of land would be flooded. Frequent annual flooding would be comparable to flooding that is now considered extreme. With a sea level rise of $100 \mathrm{~cm}$, the lower-lying parts of the coast would be flooded during moderate high tides, and only be dry during low tides. During stronger high tides, floodplains would extend over an area of more than $1,200 \mathrm{ha}$. The most heavily flooded areas would be those near river mouths. The higher sea level would hinder the runoff of water from the land, the lower parts of valleys would therefore be more wet, and river flooding and high tides occurring simultaneously would lead to the formation of vast continuous floodplains. Furthermore, sea level rise would lead to the final "disappearance" of Škocjanski zatok, the Sečovlje Saltpans, and the Stjuža Wetlands (Kovačič et al., 2016).

Figures $6 \mathrm{a}$ and $7 \mathrm{a}$ show flooded areas within the protected areas at a mean sea level rise of $50 \mathrm{~cm}$ and during strong high tides. This means that the lowest-lying parts of the coast would be covered by approximate- 

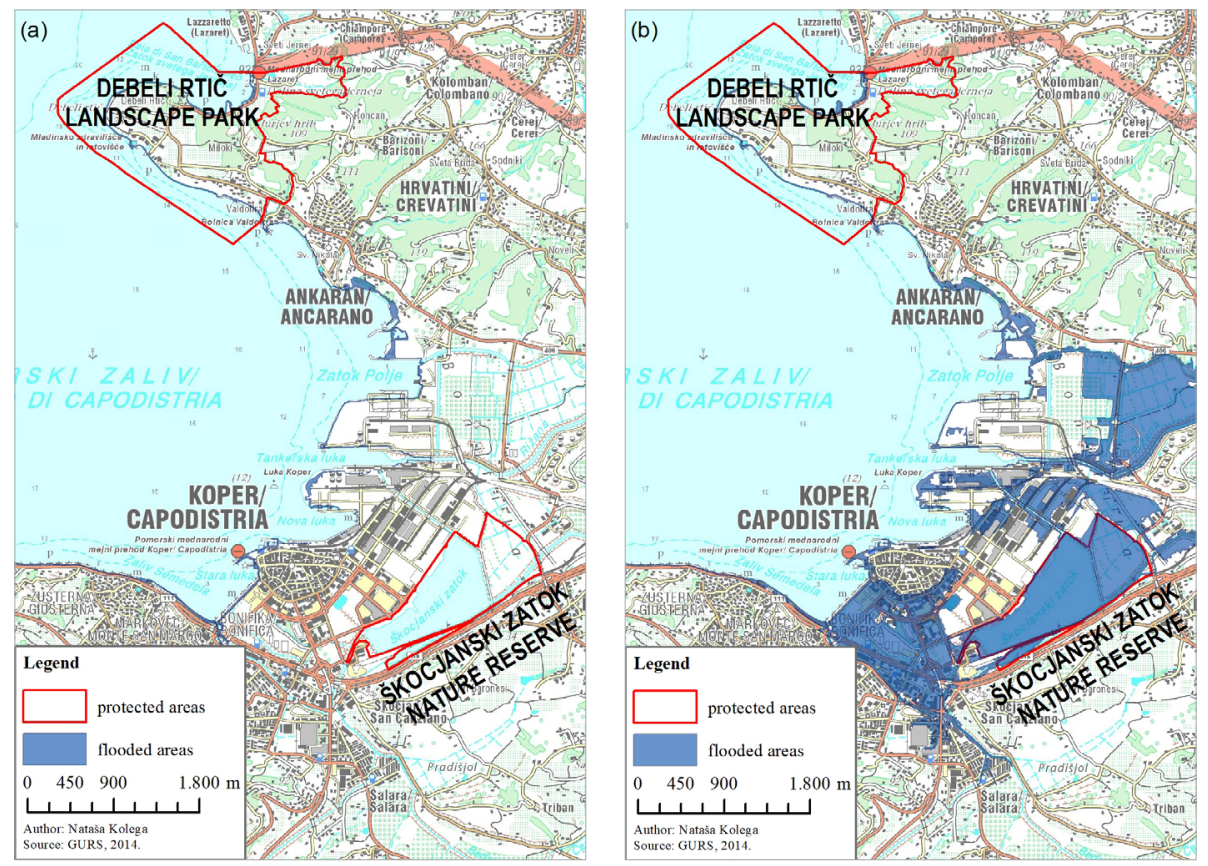

Fig. 6 Flooded areas in the event of a mean sea level rise of $50 \mathrm{~cm}$ and strong high tides (a), and in the event of a mean sea level rise of $100 \mathrm{~cm}$ and strong high tides (b), in the areas of Debeli Rtič Landscape Park and Škocjanski zatok Nature Reserve Source: Surveying and Mapping Authority of the Republic of Slovenia, 2014

ly $25 \mathrm{~cm}$ of water. Areas in the Strunjan Saltpans and the Sečovlje Saltpans would be flooded to a greater extent, as their low altitude means that they would be almost entirely flooded if the sea rose by $50 \mathrm{~cm}$. At this water level, Debeli Rtič Landscape Park and Škocjanski zatok Nature Reserve would sustain no flooding.

Figures $6 \mathrm{~b}$ and $7 \mathrm{~b}$ show flooded areas at a mean sea level rise of $100 \mathrm{~cm}$ and during strong high tides. The flooded area is comparable to what would be considered an area of extreme flooding today. Among all of the four protected areas, the least affected would be Debeli Rtič Landscape Park, as this is largely a higher-lying area. Flooding would occur in a small area close to the former border crossing point of Lazaret, and the higher sea level would make the coastal cliffs significantly more exposed to the erosional effects of the sea. Škocjanski zatok Nature Reserve and Sečovlje Salina Nature Park would be almost completely under water. In Strunjan Landscape Park, the entire area of the saltpans and the area around the Stjuža Lagoon would be 

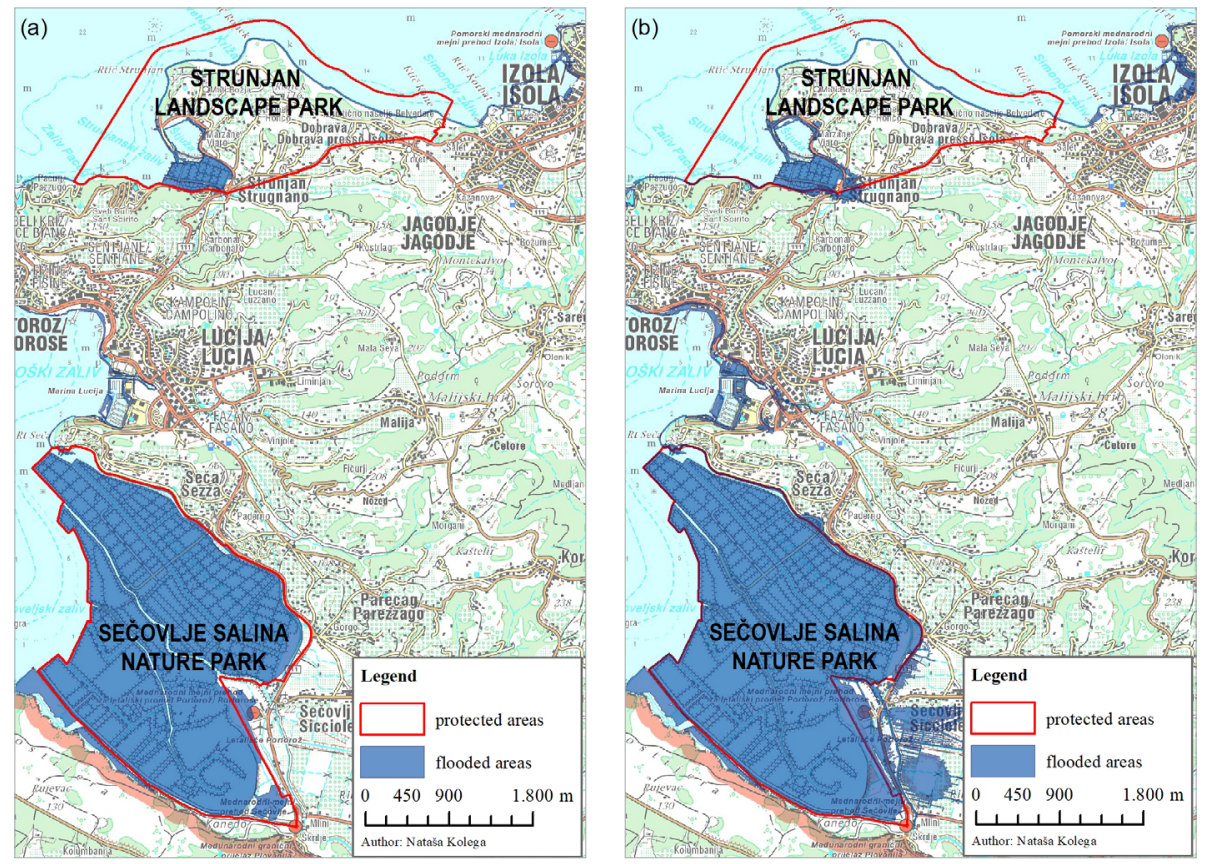

Fig. 7 Flooded areas in the event of a mean sea level rise of $50 \mathrm{~cm}$ and strong high tides (a), and in the event of a mean sea level rise of $100 \mathrm{~cm}$ and strong high tides (b), in the areas of Strunjan Landscape Park and Sečovlje Salina Nature Park

Source: Surveying and Mapping Authority of the Republic of Slovenia, 2014

flooded, and the coastal cliffs would be more exposed to the erosional effects of the sea, like those near Debeli Rtič.

\section{Conclusion}

Because the large-scale protected areas on the Slovenian coast are small in terms of surface area, and are surrounded by heavily-exploited urban and agricultural areas, they are even more vulnerable to various direct or indirect impacts. According to our findings, higher temperatures are already reducing runoff, which can alter conditions in the brackish wetlands by making them more salty. On the other hand, we can expect more frequent flooding of the wetlands due to the probable increase of extreme weather events in the future. The largest direct impact of climate change on the protected areas in question and thus on tourist visitation, however, will come from sea level rise. A large part of the Sečovlje Saltpans, the Strunjan Saltpans, and Škocjanski zatok will turn into a shallow sea, and areas of 
land along the watercourses in the hinterland will be transformed into brackish marshes. During high tides, the sea will flood riverbeds further upstream and cause the floodplains to become salinated. Water will also spread upstream along the regulated watercourses, as the higher sea level will obstruct river mouths and, during high tides, floodplains will considerably expand. In areas characterised by coastal cliffs, within the protected areas of Strunjan Landscape Park and Debeli Rtič Landscape Park, beaches will be frequently or permanently flooded, and more intense abrasion processes will take place.

Management of tourist activities on the Slovenian coast, associated with its protected areas, will have to consider the inevitable impacts of the global climate change and introduce some long-term and sustainable solutions for anticipated problems. Construction of small retention basins in the catchments of the rivers might be a sustainable solution for preventing flash flooding of the protected coastal wetlands during extreme weather events, and to enhance the discharge of the rivers in periods of rainfall shortage, preventing wetlands from becoming further salinated. Furthermore, water retention basins could also be used for irrigation. It is uncertain whether construction of higher coastal embankments is a sustainable solution for prevention of sea flooding of the low-laying protected areas. Preservation and maintenance of the very popular beaches under the coastal cliffs of Strunjan Landscape Park and Debeli Rtič Landscape Park would be a serious challenge, since the higher sea level would make it significantly more exposed to the erosional activity of the sea and the extent of the beaches would shrink.

\section{Acknowledgment}

The authors acknowledge the project Environmental effects and karst water sources: impacts, vulnerability and adaptation of land use, no. J6-8266 which was financially supported by the Slovenian Research Agency.

\section{References}

Brečko Grubar, V., Kovačič, G., 2011: Odnos prebivalcev Mestne občine Koper do Škocjanskega zatoka, in: Razvoj zavarovanih območij v Sloveniji, Regionalni razvoj 3 (eds. Nared, J. et al.), Založba ZRC, Ljubljana, 63-70.

Brečko Grubar, V., Kovačič, G., 2014: Pomen obalnih mokrišč za prebivalce slovenske Istre, Geografski vestnik 86 (2), 45-58, DOI: 10.3986/GV86203. 
Church, J. A., Clark, P. U., Cazenave, A., Gregory, J. M., Jevrejeva, S., Levermann, A., Merrifield, M. A., Milne, G. A., Nerem, R. S., Nunn, P. D., Payne, A. J., Pfeffer, W. T., Stammer, D., Unnikrishnan, A. S. 2013: Sea Level Change, Climate Change 2013, The Physical Science Basis, Contribution of Working Group I to the Fifth Assessment Report of the Intergovernmental Panel on Climate Change, IPPC, Cambridge.

Jurinčič, I., Popič, A., 2009: Sustainable tourism development in protected areas on the pattern of Strunjan Landscape Park, Varstvo narave 22, 177-192.

Kolega, N., 2005: Poplave morja na slovenski obali, Graduation Thesis, Univerza na Primorskem, Fakulteta za humanistične študije, Koper.

Kolega, N., 2015: Spreminjanje obalne črte na slovenski obali med letoma 1954 in 2010, Acta geographica Slovenica, 55 (2), 205-221, DOI: 10.3986/AGS.1887.

Kovačič, G., Kolega, N., Brečko Grubar, V., 2016: Vpliv podnebnih sprememb na količine vode in poplave morja v slovenski Istri, Geografski vestnik 88 (1), 31-36, DOI: 10.3986/GV88102.

Lipej, L., Kerma, S., 2012: Stanje in ogroženost biodiverzitete slovenskega morja, in: Geografija stika Slovenske Istre in Tržaškega zaliva (ed. Ogrin, D.), GeograFF 12, Znanstvena založba Filozofske fakultete, Ljubljana, 159-176.

Mozetič, B., Šalaja, N., 2002: Naravni rezervat Škocjanski zatok-oaza na pragu Kopra Društvo za opazovanje in preučevanje ptic Slovenije, Ljubljana.

Sovinc, A., 2011: Oblikovanje modela za učinkovito upravljanje zavarovanih območij narave, Doctoral Thesis, Univerza na Primorskem, Fakulteta za humanistične študije, Koper.

Turk, R., 2012: Zavarovana območja, in: Geografija stika Slovenske Istre in Tržaškega zaliva (ed. Ogrin, D.), GeograFF 12, Znanstvena založba Filozofske fakultete, Ljubljana, 273-289.

\section{Sources}

Debeli rtič Landscape Park, 2019: Krajinski park Debeli rtič, https://obcina-ankaran.si/sl/zivljenje-v-ankaranu/okolje-in-prostor/krajinski-park-debeli-rtic (05. 09. 2019)

Lipej, B., 2019: Strokovna sodelavka v Naravnem rezervatu Škocjanski zatok, Oral source (04. 09. 2019)

Makovac, S., 2019: Strokovna sodelavka v Krajinskem parku Strunjan, Oral source (04. 09. 2019)

Nature Conservation Act, 1999: Uradni list RS 56/99. 
Sečovlje Salina Nature Park, 2019: O parku, http://www.kpss.si/si/intro (05. o9. 2019)

Strunjan Landscape Park, 2019: O parku, https://parkstrunjan.si/o-parku/ (05. 09. 2019)

Škocjanski zatok Nature Reserve, 2019: Nastanek, http://www.skocjanski-zatok.org/rezervat/ (05. 09. 2019)

Regional Obala, 2019a: Gladina morja v Kopru se dviga: do leta 2100 tudi do 95 centimetrov, https://www.regionalobala.si/novica/gladina-morja-v-kopru-se-dviga-do-leta-2100-tudi-do-95-centimetrov-video (05. 09. 2019)

Regional Obala, 2019b: Poletna sezona v številkah: V Piranu pol milijona več nočitev, porast tudi $v$ Kopru in Izoli, https://regionalobala.si/novica/poletna-sezona-v-stevilkah-v-piranu-pol-milijona-nocitev-porast-tudi-v-kopru-in-izoli- (18. 09. 2019)

Slovenian Environmental Agency, 2019a: Podatki o dnevnih višinah morja na mareografski postaji Koper 1961-2015, Ljubljana.

Slovenian Environmental Agency, 2019b: Podatki o karakterističnih mesečnih in letnih pretokih Rižane na vodomerni postaji Kubed II (obdobje 19662017), Ljubljana.

Slovenian Environmental Agency, 2019c: Podatki o letnih padavinah ter povprečnih in najvišjih temperaturah zraka (obdobje 1961-2018) ter povprečni letni evapotranspiraciji (obdobje 1971-2010) na meteorološki postaji Portorož - letališče v obdobju 1961-2018, Ljubljana.

Slovenian Environmental Agency, 2019d: Prognozirano plimovanje morja 2019, https://www.arso.gov.si/vode/morje/Plima2019 (o6. 09. 2019)

Surveying and Mapping Authority of the Republic of Slovenia, 2009: Ortophotography, area Koper 1: 50oo, Ljubljana.

Surveying and Mapping Authority of the Republic of Slovenia, 2014: Topographical map, area Slovenian littoral 1: 50.ooo, Ljubljana. 


\title{
Chapter 6
}

\section{Nature-based tourism in the eastern part of Kraški Rob: an overview of current situation and future prospects}

\author{
Romina Rodela, Valentina Brečko Grubar
}

\section{Abstract}

In this chapter, recent literature on nature-based tourism is discussed in terms of its potential in the eastern part of Kraški Rob, in terms of characteristics and natural features of touristic interest. Kraški Rob is a geomorphological structural stage north of Slovenian Istria. It is an area of high ecological interest and parts of it have been declared Natura 2000 sites. It is rural, sparsely inhabited, and characterised by aging and declining population trends. In recent years it has begun to attract a growing number of hikers and other visitors, but still remains at the fringe in terms of regional development. Data collected from three villages-Zazid, Rakitovec, and Podpeč-is reported and an adapted version of the two-dimensional model suggested by Fredman et al. (naturalness and accessibility) has been applied to the analysis. Additionally, three features that stand out most for each of the selected villages have been identified and summarised.

Key words: nature-based tourism, leisure, sustainability, accessibility, naturalness, Kraški Rob, Slovenia 


\section{Introduction}

With the growth of interest for more sustainable approaches to regional development, and the subsequent placement of nature, and natural amenities, at the centre of local development, nature-based tourism has begun to gain traction in policy and practice. Since the early 1990s, academic literature has discussed the potential of nature-based tourism and its heavy dependency on natural amenities. Many definitions of nature-based tourism exist. In this chapter, we define nature-based tourism as including activities that take place within, and depend on, nature and natural sites and are generally undertaken far from a person's home.

The international academic debate on nature-based tourism has been developing steadily. There are many case studies from Northern European countries, where specific ideas of nature and wilderness are explored (See: Björk, 2000; Lundmark and Müller, 2010; Wall-Reinius and Bäck, 2011; Fredman et al., 2012; Margaryan and Fredman 2017; Øian et al., 2018). There is also a growing amount of empirical work from other regions within and beyond Europe (Agapito et al., 2012; Kim et. al., 2019). However, not very much has been written about nature-based tourism in Slovenia, despite tourism in Slovenia being historically linked, in one way or another, to nature and its features. It is worth noting how, over the past decades, Slovenia has been branded as a green destination at the centre of the "beautiful and pristine" Alps. It is thus interesting to note how little has been pursued in terms of theoretical and empirical systematic academic inquiry into this subject.

To that end, the tools and approaches found in literature regarding nature-based tourism are of great help for a more comprehensive study of tourism, and for an elaboration of ideas about experiences in nature, how nature matters to people, and potential uses of natural amenities in a local context for more sustainable futures. Frameworks from within this body of literature allow for in-depth analyses and also offer useful insight for regional policy-makers to strengthen the role of Slovenia as a green tourist destination. In this chapter, we seek to further elaborate on this. To do this, we looked to the most recent literature on nature-based tourism in order to develop an empirical analysis focused on Kraški Rob, an area of substantial natural value located in the southwest of Slovenia. Kraški Rob is well-known not only for its rugged relief, where limestone prevails and creates suggestive landscapes, but also as an area with high biodiversity values that is fragile from a hydrological viewpoint due to its many geomorpho- 
logical features. Despite attracting a growing number of visitors each year, the potential and suitability of tourist development in Kraški Rob has not yet been subject of a more detailed analysis. As a consequence, we do not have a systematic inventory of the resource endowment of this area, whether it is accessible to visitors, and which features have greater potential to attract visitors. Also, current opportunities, and challenges, for further development of nature-based tourism in Kraški Rob has not been discussed in detail.

First, we will conceptualise nature-based tourism with special attention on nature-society relationships. Drawing on the earlier work of Fredman and colleagues who, over subsequent articles, developed an analytical model for the study of nature-based tourism, we will undertake an assessment of natural attributes for selected sites within the eastern part of Kraški Rob. This will be done by taking into account traditions and trends of the tourism supply and demand in the greater area (Istria).

\section{Contemporary views regarding nature-based tourism}

Leisure is seen and written about as a process involving freedom, self-discovery, and growth that people, and particularly those living in highly urbanised areas, often pursue by seeking contact with nature. Some people might search for places of tranquilly to rest and regenerate the body and mind, while others might search for places where they can find adventure and excitement. Current literature conceptualises this type of engagement-activities taking place in nature-as nature-based tourism. Fredman and Tyrväinen (2010) note that academic research on the subject of nature-based tourism has its roots in the studies of outdoor recreation from the late 1960 s and early 1970 s, and has, to date, influenced the theoretical and methodological approaches to the study of nature-based tourism as line of academic inquiry. According to Fredman and Tyrväinen (2010), tourism studies and studies of outdoor recreation have both exerted major influence in terms of methods and approaches used, but also in terms of prevailing topics of inquiry. During the past 15 to 20 years, researchers have developed a systematic knowledge base regarding nature-based tourism, and it is this literature that we turned to and used for the development of this chapter.

It is relevant to note there is no agreement on a precise definition of nature-based tourism and, consequently, frameworks and analytical approaches differ across literature. For instance, Björk (2000) regards na- 
ture-based tourism in a broader sense that includes sustainable tourism, ecotourism, and adventure tourism, all of which are strongly dependent on the natural environment. In his review of definitions across selected literature, he notes how ecotourism is described as tourism where cooperation of different actors is at the core, which leads to strong local development. Furthermore, while ecotourism shares similarities with sustainable tourism, in that both deal with preservation of the natural environment, they also differ in a number of others aspects. For instance, the role of international and national policy and the influence policy should have in the development of tourism demand and supply is seen differently. Björk (2000) also differentiates ecotourism from adventure tourism, which is understood to be tourism pursued for the purpose of adventure, exposure to experience and varying degrees of risk, and excitement. In contrast, in a later review of literature, Fredman and Tyrväinen (2010) describe nature tourism as tourism pursued in natural areas with a focus on experiences of nature-based products. They identify four recurrent themes: (1) visitors to a nature area; (2) experiences of a natural environment; (3) participation in an activity; and (4) normative components related to sustainable development and local impacts, and so on. Then, as part to a later study, Fredman et al. (2012) suggest a two-dimensional framework elaborated on the experiences of nature-based products. Their framework is made of two dimensions: access to nature and naturalness (Fig. 1). In this chapter, we look closer at this framework and use an adapted version for the development of our analysis.

\section{A two dimensional framework: accessibility and perception of naturalness}

Based on a collection of selected literature, Fredman et al. (2012) develop a two-dimensional model intended for the study and further elaboration regarding the role of nature in nature-based tourism. Their model, summarised in Fig. 1, identifies two main dimensions they regard as paramount for tourism vis-à-vis the human-nature relationship: naturalness and accessibility. They suggest this model for all study of nature-based tourism, regardless of whether it is dependent on, enhanced by, or just contextualised in natural environments.

The first dimension they identify is naturalness and suggest that it should be placed on a continuum with naturalness, understood as absence of human intervention, on one end and facilities, understood as man-made 


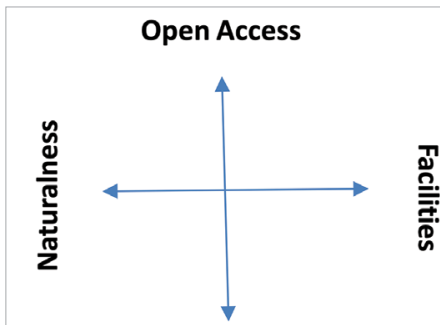

Exclusive rights

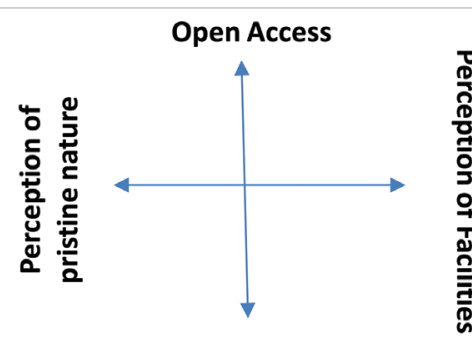

Exclusive rights

a) The two-dimensional model

b) Adapted version of the model

Fig. I A two dimensional model from Fredman et al. (2012) and its adapted version, for the study of nature in nature-based tourism

interventions in nature, on the other. Under naturalness they include natural features that are unique and often taken as the reason for the protection and establishment of protected areas, and wilderness in a broader sense. Under the second dimension accessibility they put open access on one end and exclusive rights (i.e. private property) on the other. Three types of property rights that have implications regarding the accessibility of a natural area appear in their model and these are: personal ownership; public ownership; and common-pool resources.

In Scandinavian countries and the United Kingdom, a landowner's exclusive right to land is limited by the law, in so far as others can enter and walk through land for recreational purposes as long as no crops, vegetation, animals, and natural resources are damaged. In Sweden this is known as the "Right of Public Access", and in the UK as the "Right to Roam". Similar rights can be found also in Norway and Finland. In Slovenia, most land is private property. Some is public property and there are also customary rights to land and natural resources that mostly take the form of village commons.

It is important to note that so-called "pristine nature" or nature that is still "wild" is almost non-existent outside protected areas where special zones and strict nature protection regimes are in place. Protected areas of this type are few, and visitors are not allowed in zones with strict regimes. It is against the law for unauthorised visitors to enter such areas, as it represents an unacceptable transgression on sensitive flora and fauna, and their habitats. It is interesting to note that in their study, Fredman et al. (2012, 293) acknowledge that 'natural environments are more or less impacted or manipulated by humans'. However, the implications of this are not further 
elaborated. They affirm that the degree of naturalness increases on the basis of distance from areas of human settlement (remote settlement vs. densely populated) and natural areas closer to urban areas are understood to be less natural compared to those further away. We do not find this to be an accurate representation of natural areas in Europe.

In Europe, inclusive of Slovenia, landscapes have been shaped by humans in one way or another. The idea of naturalness, as an absence of human intervention, has been adjusted to reflect most closely what we understand to be the prevailing reality of anthropogenised landscapes. Therefore, we would suggest a change in the model, namely, changing "naturalness" to "perception of naturalness" in order to allow the exploration of how visitors perceive nature, or "pristine" nature. Consequently, instead of defining remoteness as distance from settlements and wilderness as absence of human intervention, the reinterpreted version we used for our study focuses on the expectations visitors have of nature and its natural attributes. This shifts the focus on individual experiences with nature. Lund (2013) offers a useful critique of the artificial divide between nature and culture that is often used in the tourism industry to promote tourism products and experiences, and to appropriate certain areas for selected activities, leaving out the actual dynamic that occurs physically when a tourist actually interacts with his or her surroundings.

\section{Methods}

For this chapter we focus on Kraški Rob, which is an area of great natural interest that has not received much attention in current literature, despite the amount of visitors it attracts. The area is also of an analytical interest because it is understood to be fragile and, as such, land and resources need to be managed in specific ways. In the following sections more information is provided about the research area, and the methods of data collection that we used are introduced.

Data collection occurred in the period from April $1^{\text {st }}$ to $4^{\text {th }}, 2019$ and was undertaken by a group of seven students enrolled in the $2^{\text {nd }}$ and $3^{\text {rd }}$ years of the undergraduate study programme of Geography at the University of Primorska (Slovenia). The team was coordinated by the second author, who oversaw preparations and coordinated data collection in the field. Preparatory work, conducted in March 2019, included a discussion of the larger geographical area of research interest with a geo-location of selected 
settlements (Rakitovec, Zazid, and Podpeč) and their surrounding areas. Data collection was planned as a four-day endeavour in the research area.

The team started with a long walking tour of the selected area, from Lačna above Gračišče to Zazid (Lačna-Kuk-Rakitovec-Lipnik-Zazid) to obtain a first impression. Thereafter, each day the team surveyed one village and its surroundings, making for a total of three villages for the whole period.

During the four days of data-collection, the team undertook observation of the natural environment and also administrated open-ended interviews with locals. Observation focused on the inventory of natural and cultural features, which were documented in written and photographic form. Overall, the team talked to the following local residents:

- $\quad$ two men, both retired (70+ years old) and a local woman (50-55 years old) who is active in organising village events in Rakitovec;

- $\quad$ one entrepreneur in tourism (45-50 years old), a retired women (7o+ years old), and a local farmer ( 30 years old) in Zazid; and

- one livestock farmer (55-60 years old) and one local women employed in the nearby urban area (roughly 40 years old) of Podpeč.

The interviews were open-ended group conversations, focused on local amenities and natural and cultural aspects of interest. During the interviews, local respondents were free to bring up whatever they wanted to talk about, and the research team took notes. No audio recording was undertaken.

Based on observational and interview data, the team undertook an assessment of the current situation and future prospects regarding amenities of touristic interest. For the purpose of this study, accessibility and perception of naturalness were considered regarding the amenities the team shortlisted. The team of surveyors provided a summary of their own impressions and expressed preferences for the amenities that they enjoyed most (Tab. 1).

\section{Description of the study area: the eastern part of Kraški Rob}

Kraški Rob is a geomorphological structural stage at the junction of limestone with flysch in the northern part of Slovenian Istria, which gives its name to a wider area $20 \mathrm{~km}$ long and 2 to $5 \mathrm{~km}$ wide (Fig. 2). Kraški Rob is also the intended name of a prospective protected nature area, the extreme eastern part of which falls within our study area. The area called Kras is a 
CHALLENGES OF TOURISM DEVELOPMENT IN PROTECTED AREAS OF CROATIA AND SLOVENIA

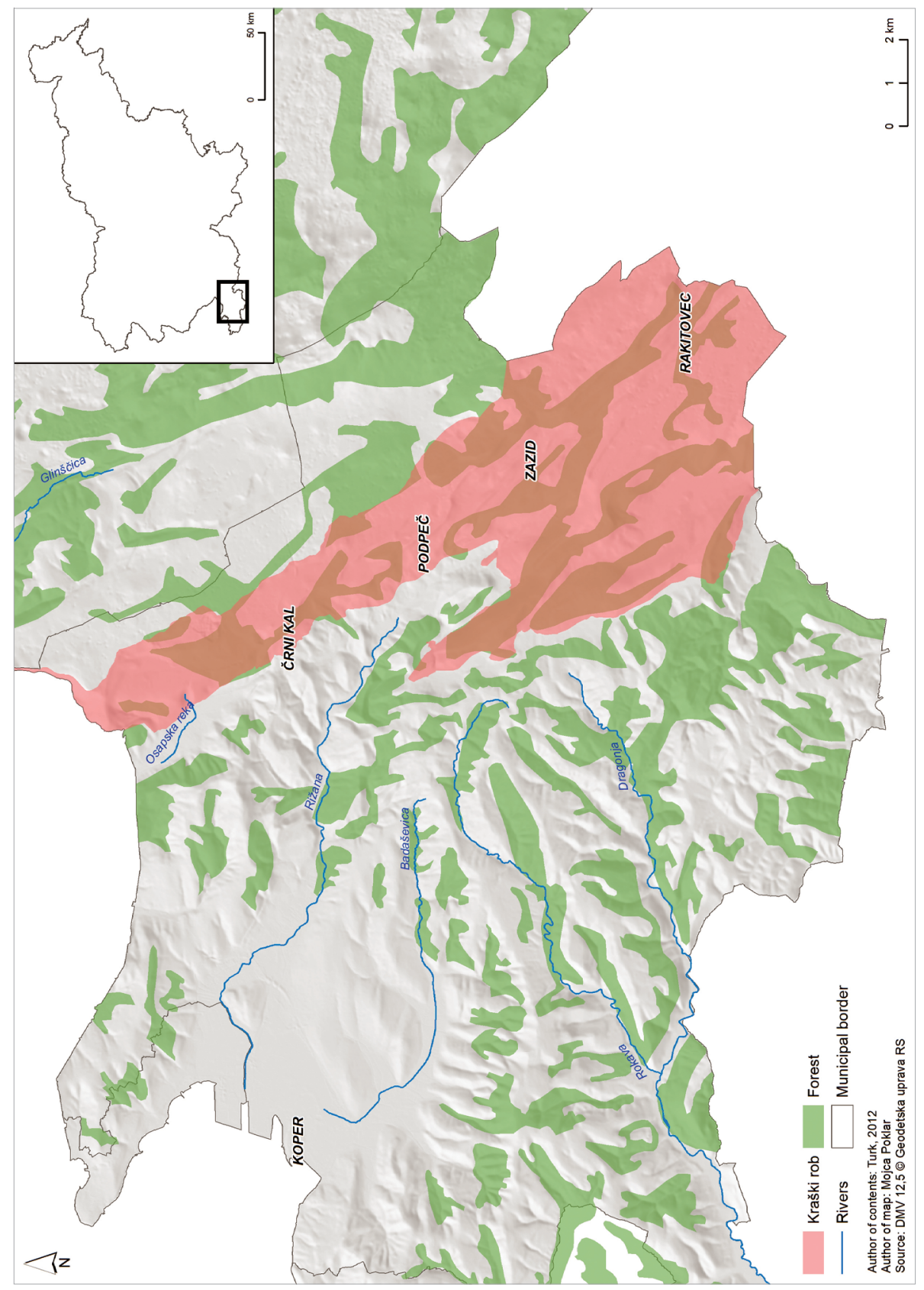

Fig. 2 Geographical location of Kraški Rob 
Natura 2000 site and an area of ecological interest. There are several natural features of interest and those found in our study area are: Movraški Kuk; Rakitovski Kras; the grasslands at Golič, Lipnik and Kavčič; and Črni Kal-Hrastovlje Wall (Slovenian Environment Agency, 2019).

Kraški Rob has unique relief, vegetation, and fauna features. It hosts many rare and endangered plant and animal species, which contribute to making Kraški Rob an internationally important bird habitat (See: Turk, 2012). Due to its southern location and warm limestone base, Mediterranean tree and shrub species thrive on the southern slopes of Kraški Rob (e.g. holm oak and laurel). Grasslands found here are an important habitat for orchids and other endemic flora growing along the walls and in the cracks of Kraški Rob (Turk, 2012).

Kraški Rob is a tectonically-based relief formed by the tempering of older limestone on younger flysch rocks. The landscape is very steep, with rocky slopes and walls, and extends from the border with Croatia in the southeast to the border with Italy in the northwest, and continues into both neighbouring countries. Geologists refer to the tectonic unit as the scaly structure of Čičarija and is the result of the subversion of Istria towards the northeast or the movement of Čičarija towards the southwest (Placer, 2007). Due to their low resistance and erosion processes, over time flysch rocks diminished and more resistant limestone rocks spread over 47 cliffs, measuring $51 \mathrm{~km}$ in total length. The longest (over $3 \mathrm{~km}$ ) are found above the settlements Črni Kal, Črnotiče and Podpeč, and the highest are found above Osp (160 $\mathrm{m})$ and Zanigrad (103 $\mathrm{m})$. The limestone stage was transformed by the process of karstification, causing many interesting relief forms to take shape, such as rocky lowlands, tunnels, caves, and sig formations (Natek et al., 1993).

The limestone structural stage, however, is not only a dividing line in the relief, but also in climate, soil, vegetation, and land use. The top part of the structural stage is the karst plateau, which is located in two altitude bands. The first is Rakitovsko-movraški Karst, which, with the exception of its peaks, does not exceed $400 \mathrm{~m}$ a.s.l. The second is the eastern continuation of Podgorje Karst onto Čičarija Plateau, with altitudes above $600 \mathrm{~m}$. Both areas of karst are characterised by grassland coverage, and to a lesser extent, rockiness on the surface, as well as sinkholes and dry valleys. In the past, these grasslands served as pastures where locals put up dry stone walls to mark property. It was also common to find dry stone walls around declines where locals would cultivate small gardens on small stretches of 
fertile land (Ogrin and Mužina, 2005). Over the past decades, grazing diminished, but today more farmers have livestock so grazing is gradually being reintroduced into Rakitovsko-movraški Karst. The higher grasslands are less grazed on and overgrown, even though they become overgrown more slowly than lower areas. Currently, the dry karst meadows are environments recognised for their exceptional diversity in terms of flowering plants and dolines, and are mostly overgrown with tree and shrub species (Kaligarič, 1997; 2005).

Land use for agricultural production is limited to the valley bottoms and terraced slopes around settlements in the Kraški Rob. It is mainly intended for the production of food for self-sufficiency. The conditions for the growth of cultivated plants vary considerably in the study area, this due to the different altitudes and varying distance from the sea. The surface rises from Podpeč to Rakitovec by 150 m, while Rakitovsko-movraški Karst, which continues westwards in the hinterland, stands between this area and the sea. Rakitovec has a noticeably cooler climate, which does not allow the cultivation of grape vines and plants that need warmth, while in Zazid grapes (and other warmth-dependent crops) thrive in the most favourable sun-facing locations. Podpeč has perhaps the best conditions for agriculture in the area.

\section{Results and discussion}

During data collection, numerous natural and cultural amenities were identified and inventoried by the team. Then, with consideration of naturalness and accessibility, as suggested by the model above, a selection of amenities with greater potential was shortlisted.

Rakitovec lies at $530 \mathrm{~m}$, near the border with Croatia in the southeastern part of Kraški Rob. Much of this settlement is located on a steep slope at the foot of Kavčič, above Rakitovska vala, and a smaller and younger part in the vicinity of Rakitovec railway station along the Prešnica-Pula route. In the older part of Rakitovec (Fig. 3), houses are close to each other and are located on terraces connected by narrow roads and paths. The part close to the train station is less densely built and most houses have gardens.

Zazid lies at an altitude of $387 \mathrm{~m}$, on the sunny slope of Lipnik (Fig. 4). The older part of Zazid is densely built around a central square with a church and cemetery. The roads and paths in the settlement are very narrow. The newer part of Zazid, however, spreads into the eastern periph- 


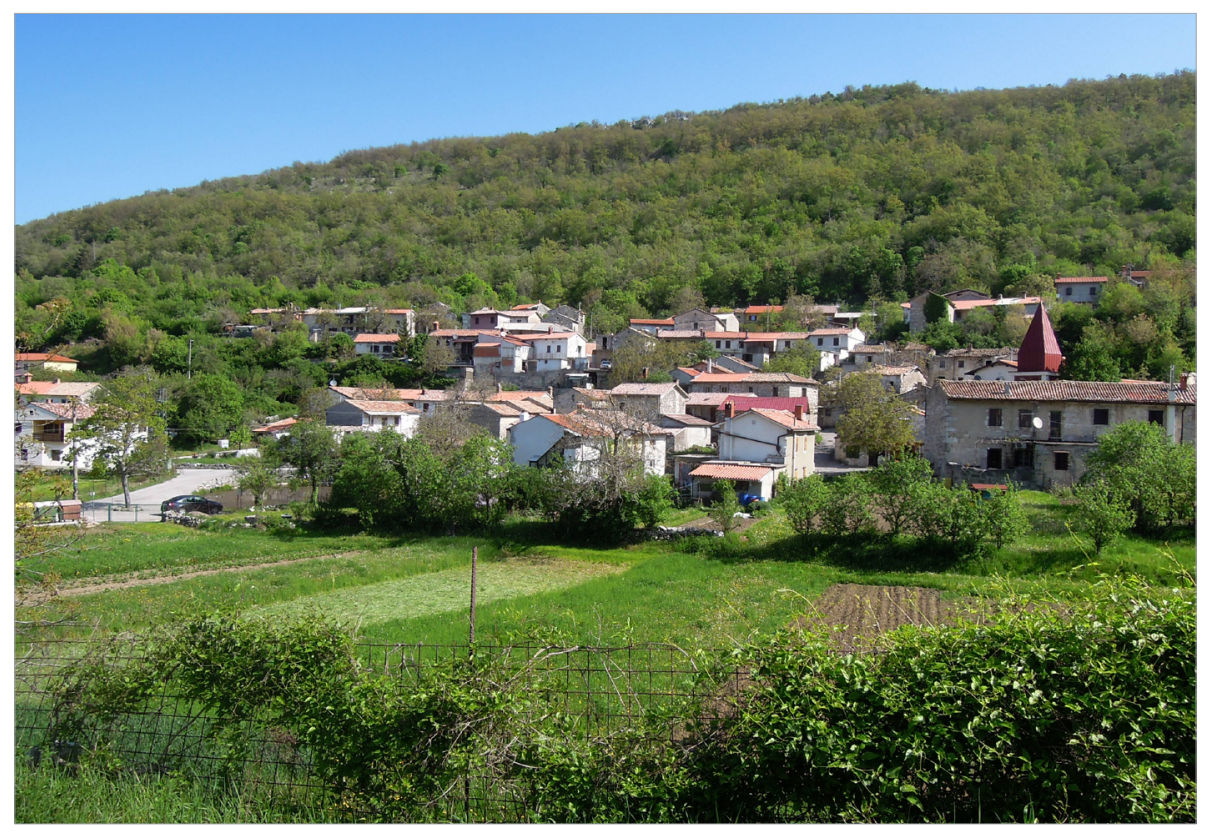

Fig. 3 Rakitovec village

Photo by Valentina Brečko Grubar, 2019

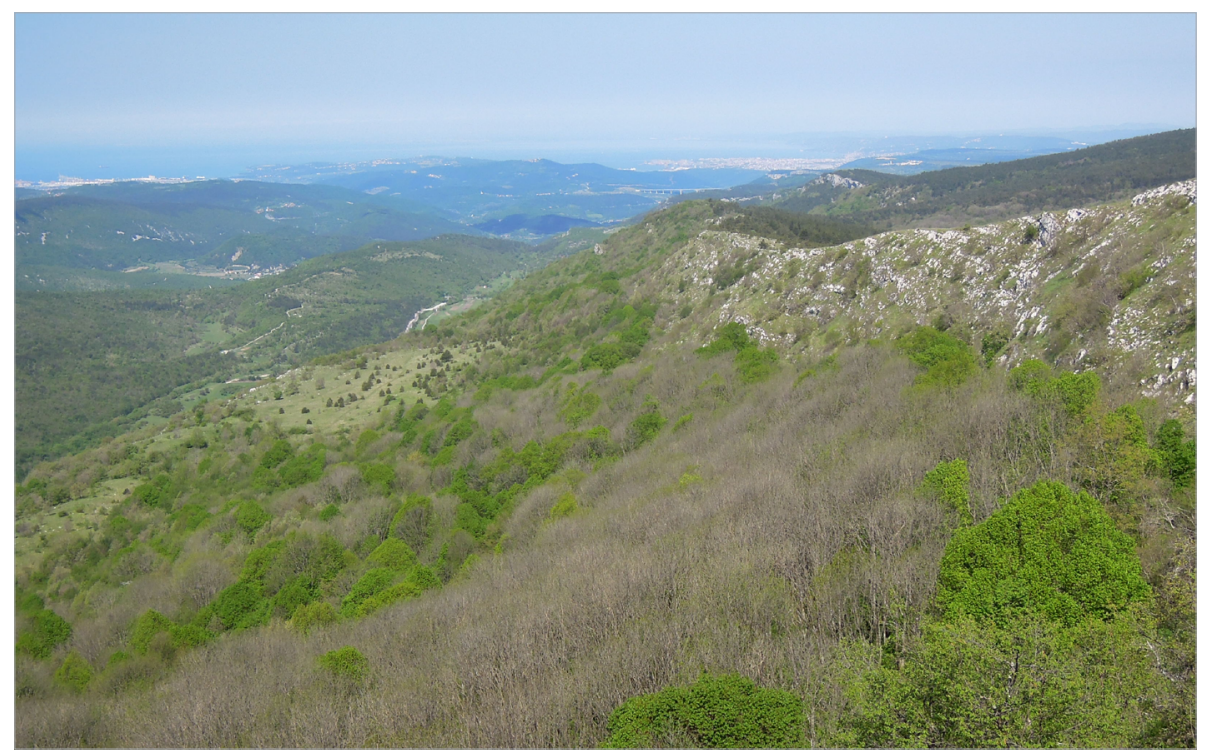

Fig. 4 View from Lipnik

Photo by Valentina Brečko Grubar, 2019 
ery and is less dense. Several water sources can be found in the vicinity of Zazid.

Finally, Podpeč has an exceptional position as it is located below a rock wall (Fig. 5). It lies at an altitude of $311 \mathrm{~m}$, at the top of a steep slope descending into the upper part of Rižana Valley. Spatially, Podpeč is a very narrow settlement with no space to expand. Houses are placed very close to one another between the rock wall and the road, and the Prešnica-Koper railway line. On the eastern part of the settlement lies a large karst spring that is used for the settlement's drinking water supply.

In terms of the size of local population, there were 116 residents in Rakitovec, 77 residents in Zazid, and 47 residents in Podpeč in 2019 (Statistical Office of the Republic of Slovenia, 2019). These three settlements have documented population decline since World War II, as most young people leave in search of better living conditions. The result of outmigration is that many houses are empty and decaying. In recent years, the population is stable but aging. There has only been a minimal influx of new residents over the past decade.

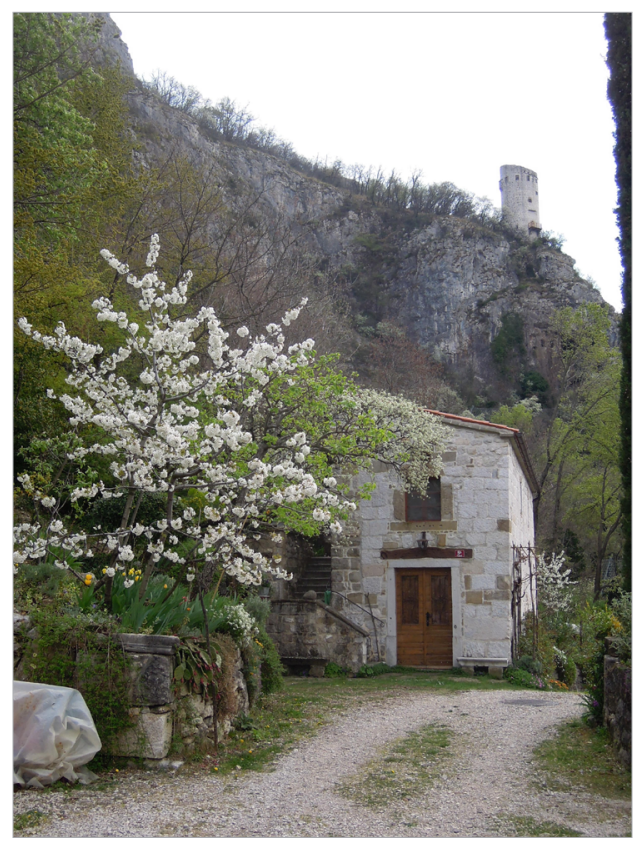

Fig. 5 The rock wall and defence tower above the Podpeč

Photo by Valentina Brečko Grubar, 2019 
It is useful to note that the villages lack services as there are no restaurants, bars, shops, or markets. There are only limited opportunities for overnight accommodation at a few recently renovated houses in Zazid and Podpeč. These facilities can host only a small number of visitors, who have to be prepared to source and cook their own food. There are no restaurants or catering services in the area. Thus, in terms of tourism, the area remains dependent on the nearby larger villages or other urban settlements for supplies, gastronomy, and so on. The nearest larger towns or urban centres are at least 20 minutes distant by car. Despite the lack of services, there is substantial untapped potential within these villages. The team also collected information about locals who farm professionally and/or own livestock, who produce cheese and meat products that are sold on their farms. Several other households grow vegetables for their own needs.

During data collection, interaction with locals from the three villages proved to be very smooth and pleasant. Villagers were welcoming and showed concern for local heritage and nature. Given the scarcity of food supplies (stores) in the area, respondents mentioned that they occasionally help hikers with water, coffee, and friendly conversation.

Also it was reported that, in addition to hikers who use the trials that the Slovene Alpine Association manages, there are visitors who come for biking tours and recreational free-climbing (Fig. 6). Kraški Rob is a wellknown attraction among free climbers, who come from across the wider region and Central Europe. However, most choose to stay further west on the Slovenia-Italy border as there are more accommodation, shops, and other services available.

All three settlements are characterised by partially-preserved typical architecture. Stone constructions with special elements such as carved window and door frames, courtyard entrances, porch entrances, annexes, chimneys, etc. (Fig. 7).

Unfortunately, there are many empty and derelict buildings, especially in Rakitovec. Other cultural heritage and popular architecture is also present (Fig. 8, Fig. 9) and there are sites of archaeological interest. In past eras, this area had an important strategic position. Kraški Rob served as a route connecting the sea to Carniola and Čičarija, and various trenches, fortifications, and traces of that period can still be found today. During recent excavations, remains from the Palaeolithic and later periods were discovered in caves and on the slopes near the settlements of the study area. 


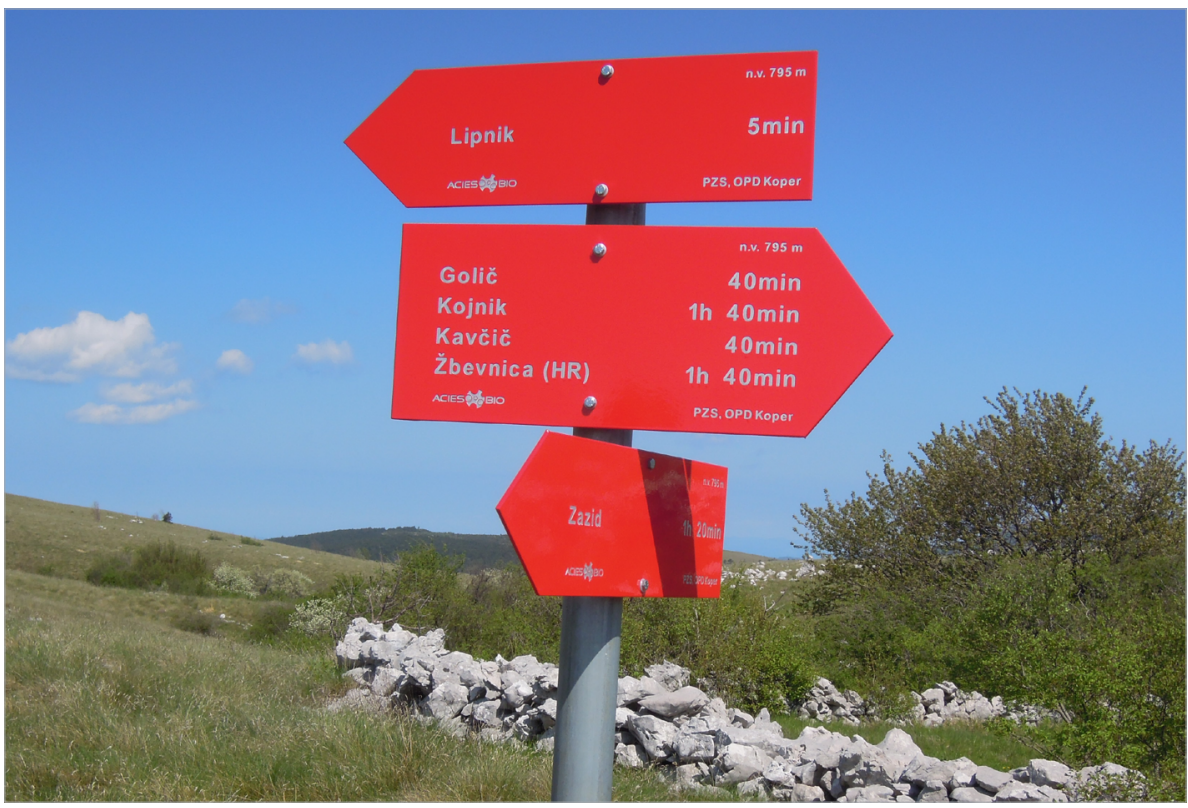

Fig. 6 Marked mountain trail on Podgorje Karst and Čičarija Photo by Valentina Brečko Grubar, 2019

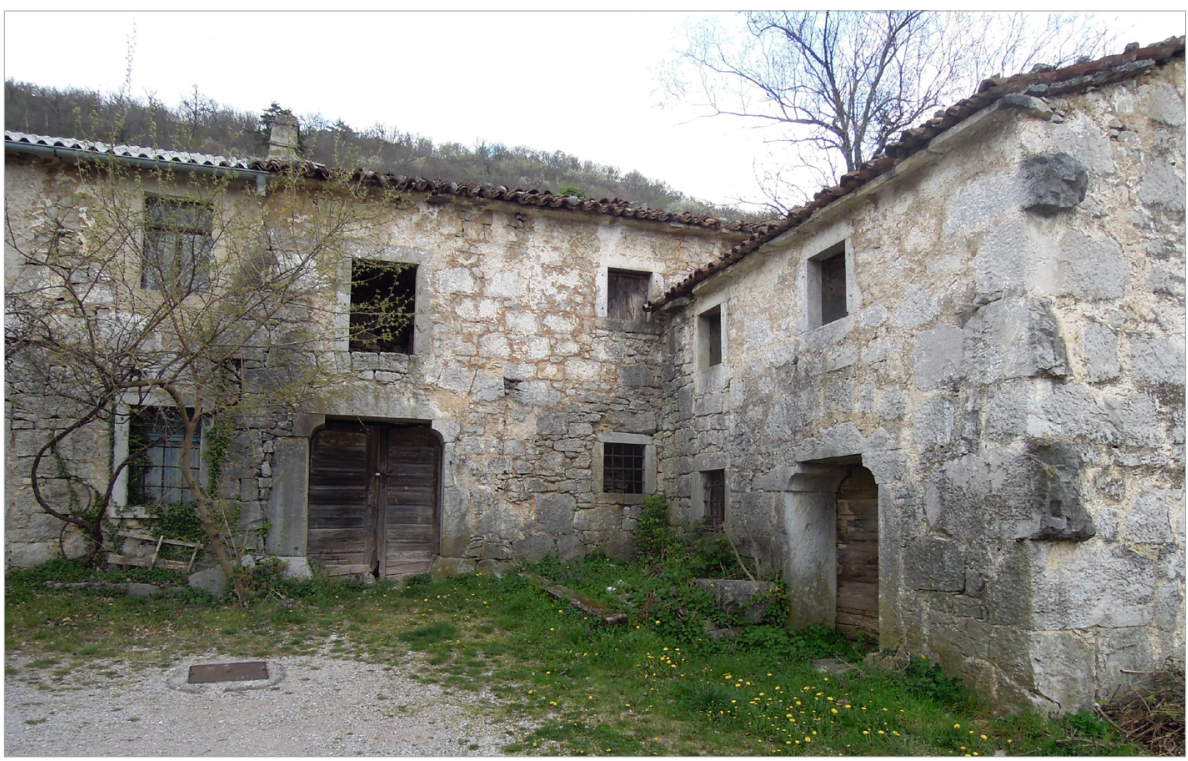

Fig. 7 An Istrian (vacant) house in Zazid

Photo by Valentina Brečko Grubar, 2019 


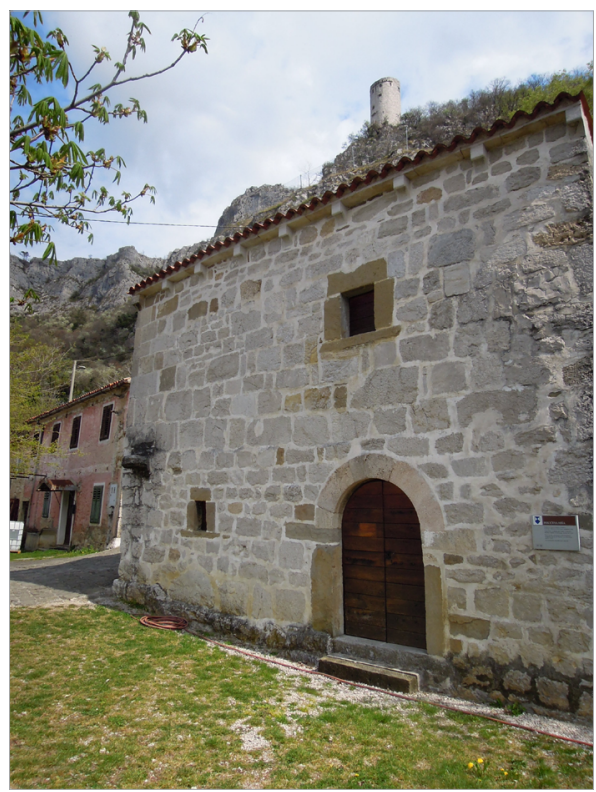

Fig. 8 The Prkič House, Podpeč

Photo by Valentina Brečko Grubar, 2019

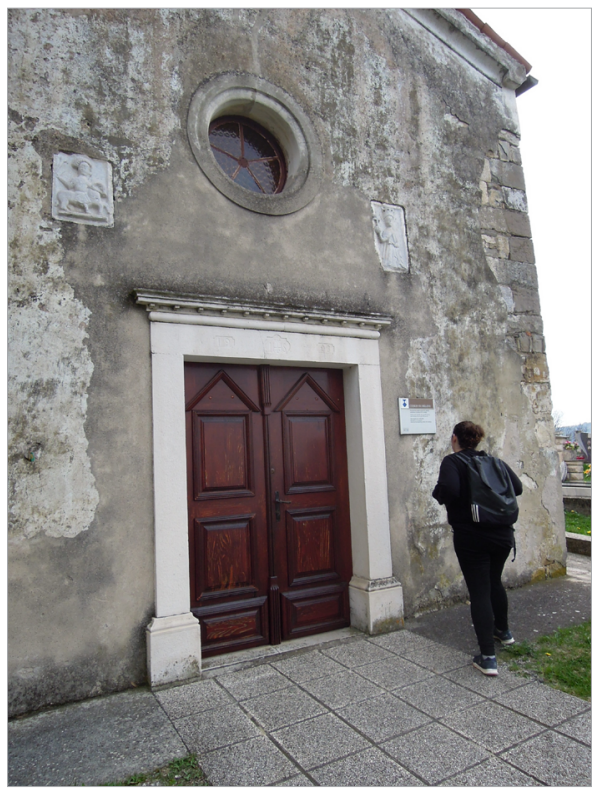

Fig. 9 Church of St. Helene with burial ground, Podpeč

Photo by Valentina Brečko Grubar, 2019 
During data collection, the team surveyed and identified thirty amenities of potential touristic interest: eleven in Rakitovec; eight in Podpeč; and eleven in Zazid. Natural amenities included dry meadow, karst caves, karst dolines, and wild flowering plants (Fig. 10).

However, during the last meeting session, the group collectively agreed on the amenities which they short-listed as those with the greatest potential for attracting tourists. These are listed and described in Tab. 1 and ranked accordingly.

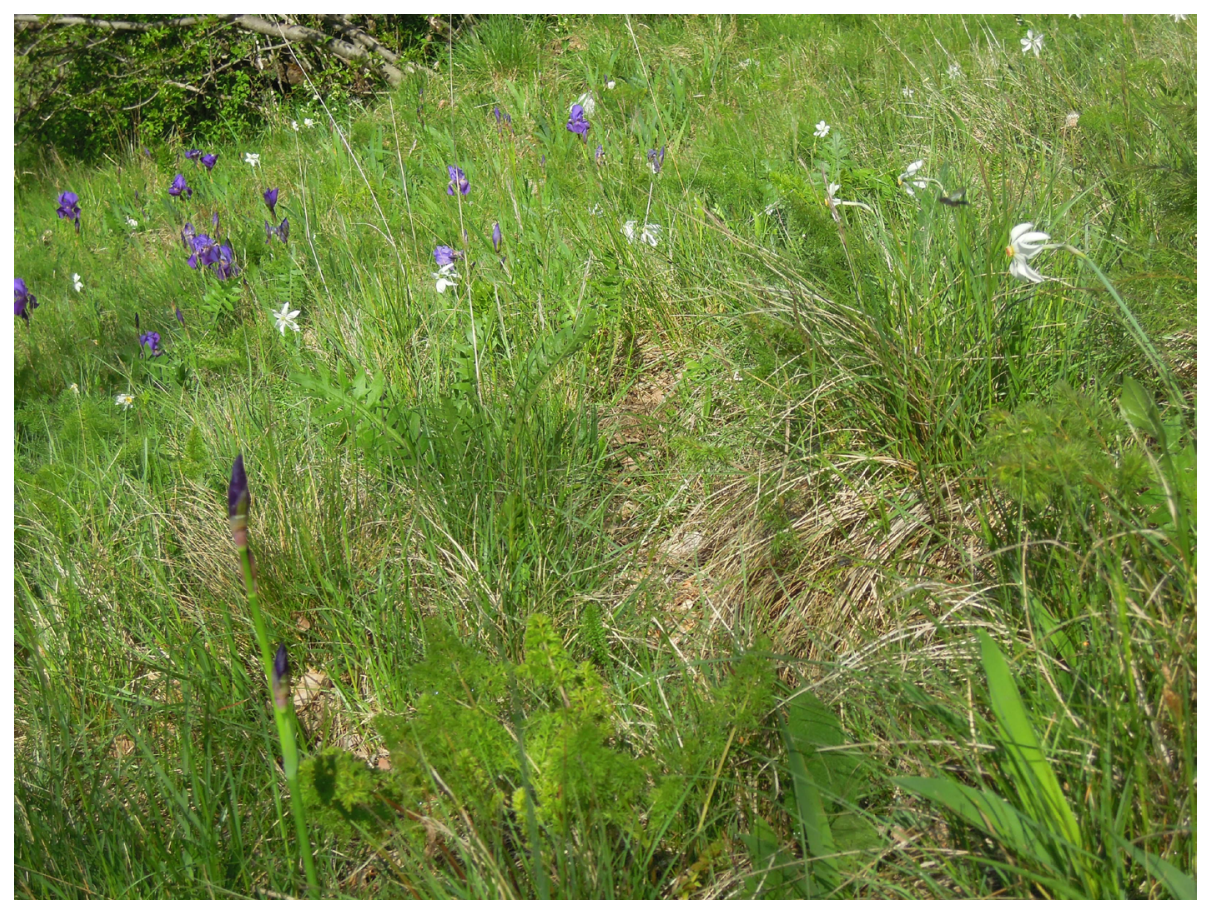

Fig. Io Karst meadows above Rakitovec

Photo by Valentina Brečko Grubar, 2019 
Tab. I Summary of naturalness and accessibility of selected amenities in the eastern part of the Kraški rob

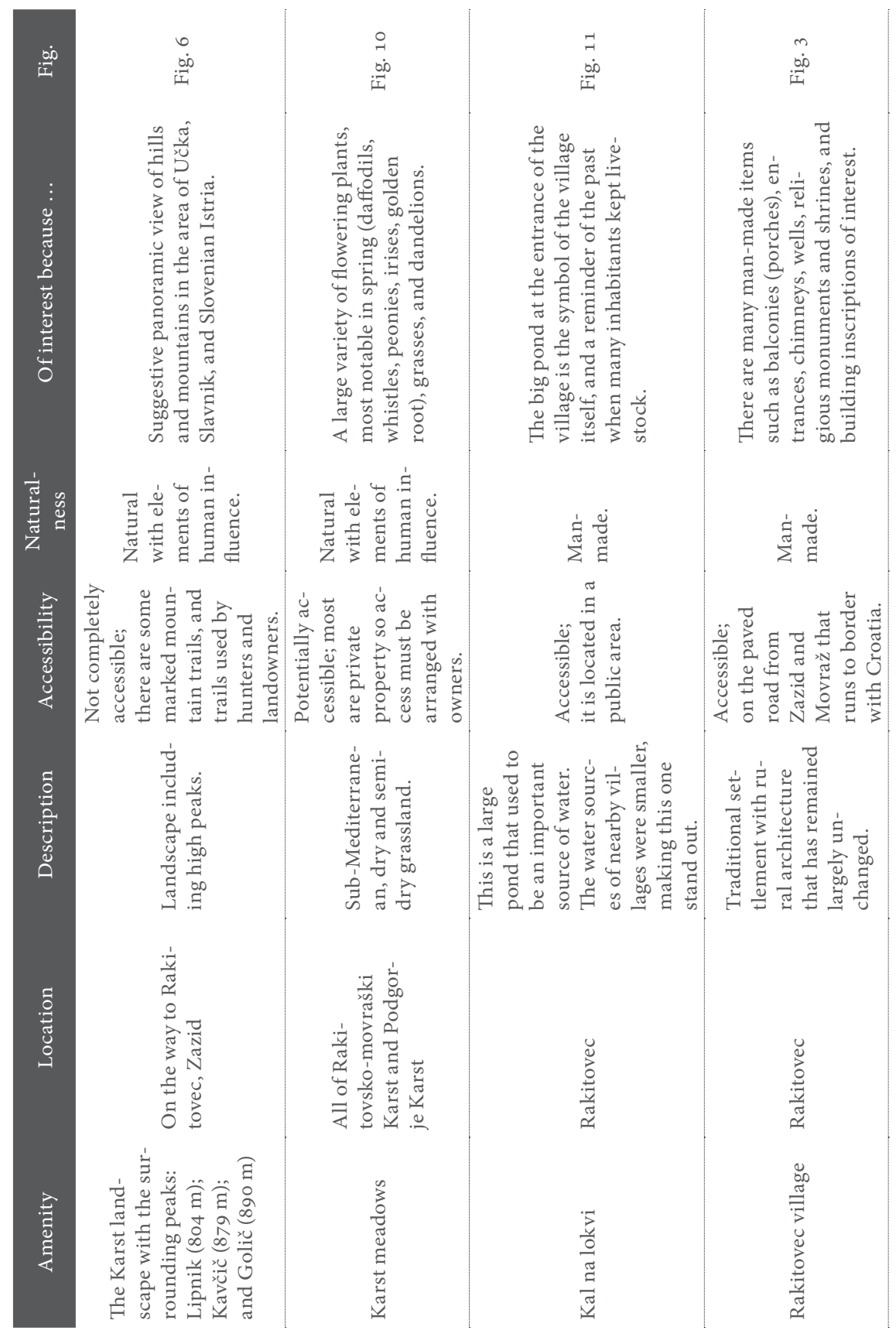


Tab. I Summary of naturalness and accessibility of selected amenities in the eastern part of the Kraški rob (continued)

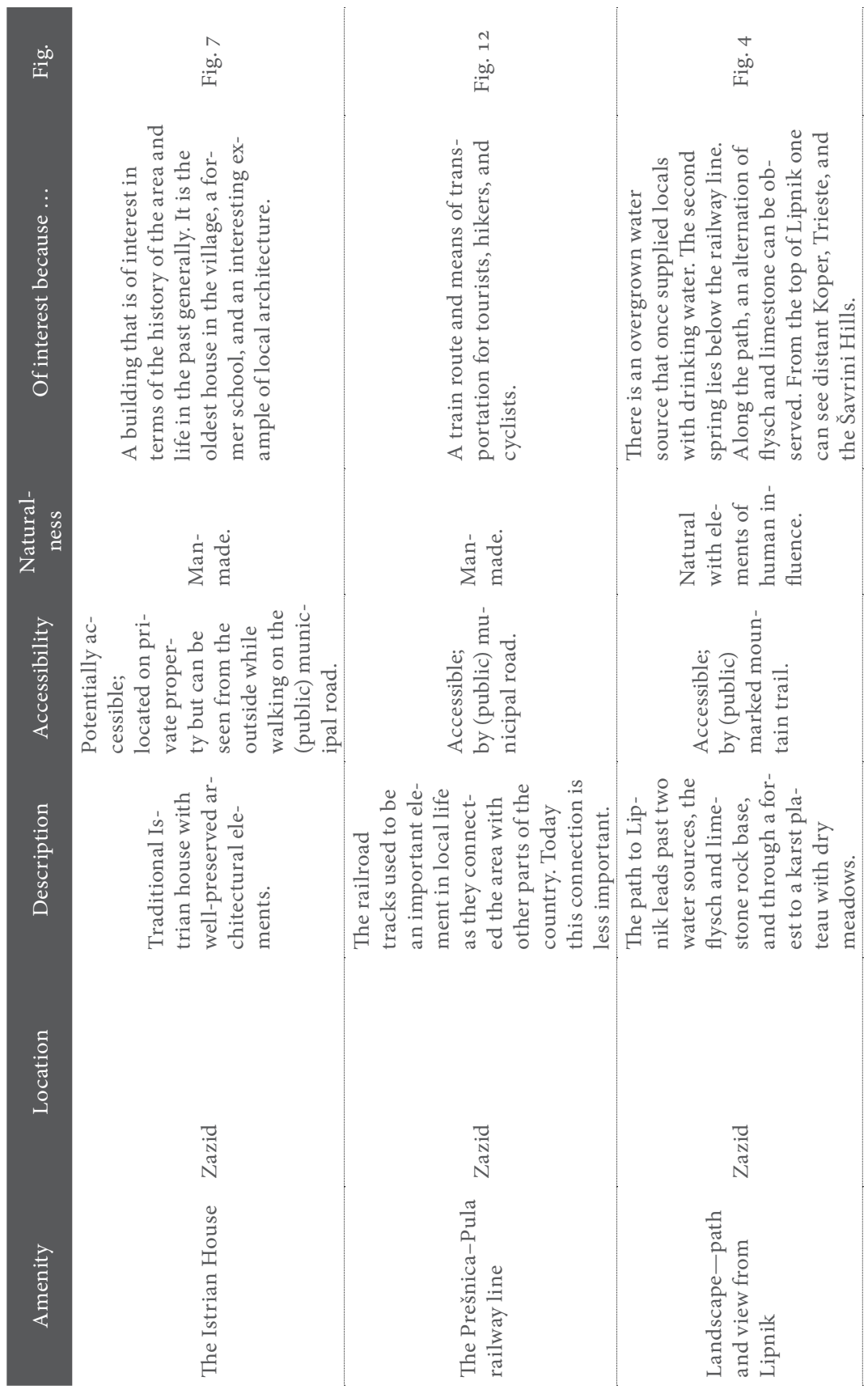


Tab. I Summary of naturalness and accessibility of selected amenities in the eastern part of the Kraški rob (continued)
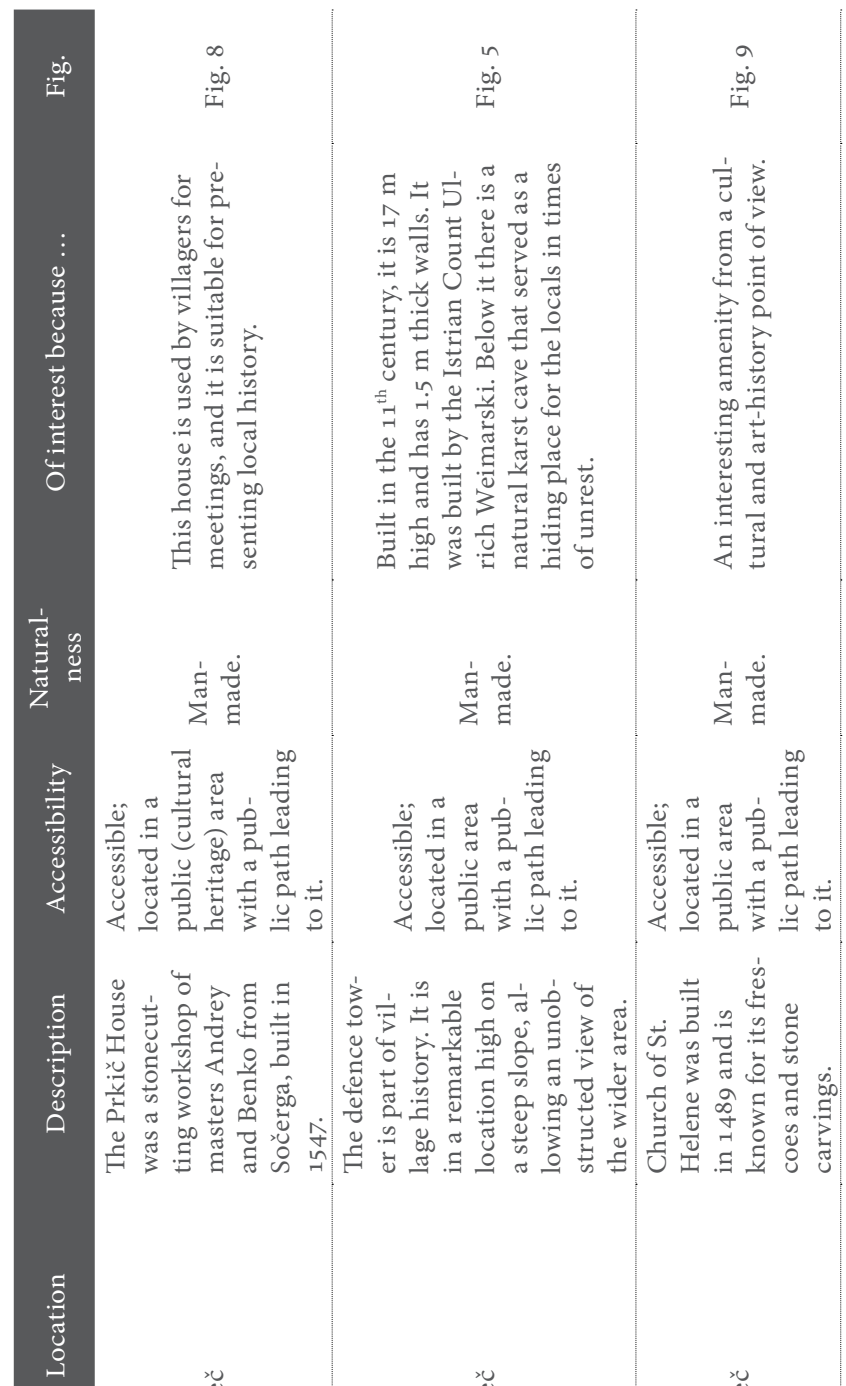

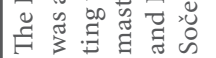

J 
It is significant that most of the amenities selected are either semi-natural karst landscapes, or other nature features with man-made aspects (Fig. 11, Fig. 12). If we look back at the model of Fredman and Tyrväinen (2010) we can see that none of the selected sites are located on the extreme side of the naturalness category (See: Fig. 1). This is interesting for several reasons. Namely, during the first day the team was most interested in and visited the most relevant peaks and karst landscapes, however, as field work progressed and the team began to interact with locals, their perception changed-in terms of nature and of which of its aspects were most interesting. Interactions with villagers allowed for a new context to emerge and helped the team learn about human-nature interactions in the area, and related challenges regarding water scarcity-a problem faced by many karst areas.

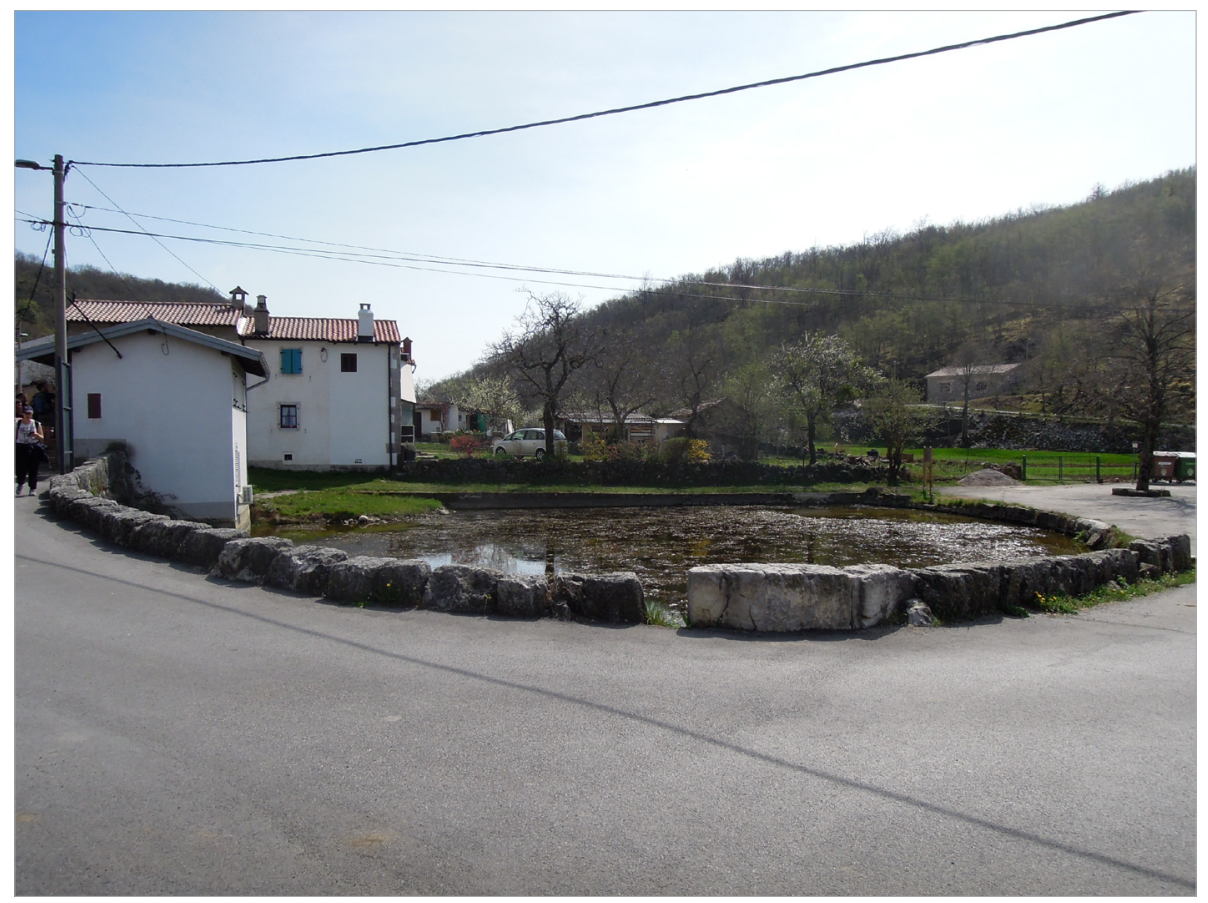

Fig. II Kal na lokvi, Rakitovec

Photo by Valentina Brečko Grubar, 2019 


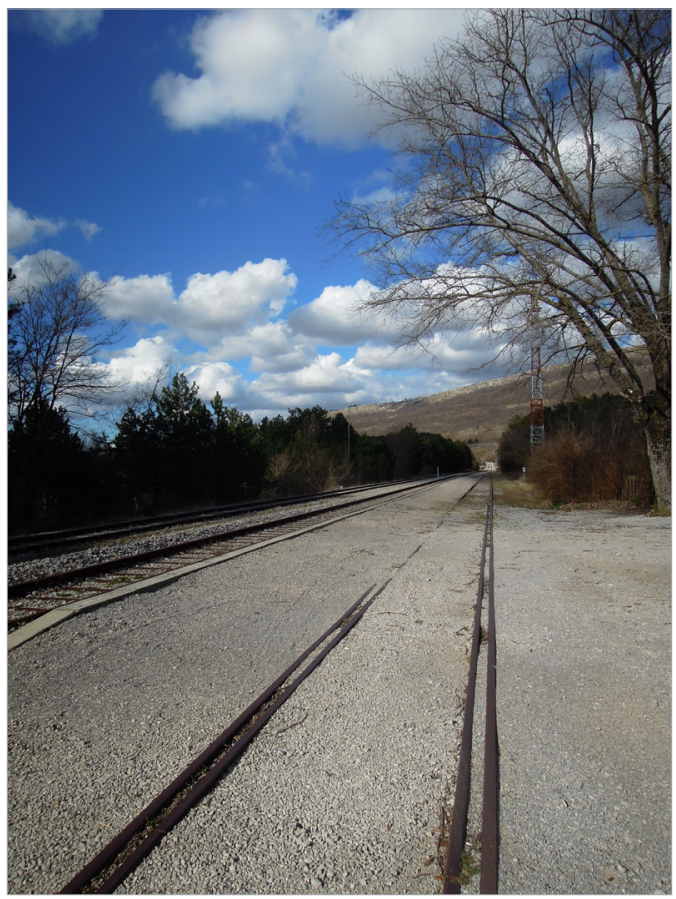

Fig. I2 The Prešnica-Pula railway line

Photo by Valentina Brečko Grubar, 2019

\section{Conclusion}

In this chapter we chose to focus on nature-based tourism and explore ideas and tools developed in this field of academic inquiry. We found that literature from Scandinavian countries most attracted our interest. We choose to borrow an adapted version of the model of naturalness and accessibility proposed by Fredman et al. (2012) and draw on Lund's (2013) ideas regarding experiencing nature, in order to perform an analysis of the study areathe eastern part of Kraški Rob-with the aim of surveying its current potential in terms of nature-based tourism.

We noted that Kraški Rob is strongly characterised by natural features of attractive appearance and majestic karst slopes where traces of human intervention are constant throughout. Field work revealed that in the eastern part of Kraški Rob, different combinations of naturalness and accessibility could be found, and a state of semi-naturalness and privately-owned land (that may or may not be accessible) prevailed. 
In her study, Lund (2013) pointed out that the experience people have when in nature is not completely universal, given that people define nature 'in relation to how they experience it, engaging with it'. She goes on to say that there are different degrees of nature, and people appreciate nature in various ways, which is influenced by how they interact with it. The research team had a perspective-expanding experience, and found that their pre-conceived notions about Kraški Rob changed appreciably after their interactions with the area and its residents. Almost all of the amenities they eventually shortlisted have been, in one way or other, shaped by local inhabitants.

To conclude this chapter we would like to outline a few recommendations for literature and for practice and policy. First, regarding the two-dimensional model used, future research could explore the way in which naturalness, as found in karst landscapes (stones and scarce vegetation) is perceived by visitors and how this, coupled with accessibility, impacts their experience with nature. Further understanding of this might reveal which aspects are most likely to make people want to return. Second, regarding policy, local decision-makers should take into account that this area could be of interest to those who like to spend time outdoors and enjoy nature, but its potential is limited by the lack of certain services. The success of nature-based tourism lies in attractive natural assets with the addition of competitive tourism supply (e.g. accommodation) to cater to visitors across different segments. This area already attracts hikers, bikers, and free-climbers, but because it lacks core services, most visitors find accommodation and food elsewhere, which is a missed opportunity for the local economy. Third, tourism is about leisure time and it should boost positive sentiment for visitors to want to return (and to tell others how nice it is, so they too might want to come). It is not very clear how the derelict houses and the damaged parts of these villages might impact the experience of visitors. Certainty, questions might be raised regarding safety and general aesthetics of the village itself. Thus, there is a need for broad strategies to deliver not only services, but also opportunities for the local community to mend and restore damaged houses.

\section{Acknowledgments}

The authors would like to thank the students who undertook data collection and the local residents. We also thank Mojca Poklar, PhD, for helping us out with the map (Fig. 2). Romina Rodela gratefully acknowledg- 
es the financial support covering access to literature and hours of work by the project "Contemporary trends in globalization and localization: challenges and opportunities faced by marginal rural areas" granted by ADFUTURA (Javni štipendijski, razvojni, invalidski in preživninski sklad Republike Slovenije).

\section{References}

Agapito, D., Mendes, J., Do Valle, P. O., 2012: The rural village as an open door to nature-based tourism in Portugal: The Aldeia da Pedralva case, Tourism 60 (3), 325-338.

Björk, P., 200o: Ecotourism from a conceptual perspective, an extended definition of a unique tourism form, International Journal of Tourism Research 2 (3), 189-202, DOI: 10.1002/(sici)1522-1970(200005/o6)2:33.3.co;2-k.

Fredman, P., Tyrväinen, L., 2010: Frontiers in Nature-Based Tourism, Scandinavian Journal of Hospitality and Tourism 10 (3), 177-189, DOI: $10.1080 / 15022250.2010 .502365$.

Fredman, P., Wall-Reinius, S., Grundén, A., 2012: The Nature of Nature in Nature-based Tourism, Scandinavian Journal of Hospitality and Tourism 12 (4), 289-309, DOI: 10.1080/15022250.2012.752893.

Kaligarič, M., 1997: Rastlinstvo Primorskega krasa in Slovenske Istre - travniki in pašniki, ZDJP and ZRS, Koper.

Kaligarič, M., 2005: Rastlinstvo Rakitovca in okolice, in: Meje in Konfini, Rakitovec, vas kulturnih, družbenih in naravnih prepletanj (ed. RožacDarovec, V.), ZRS, Koper, 333-336.

Kim, Y., Kim, C.-K., Lee, D. K., Lee, H.-W., Andrada II, R.T. 2019: Quantifying nature-based tourism in protected areas in developing countries by using social big data, Tourism Management 72, 249-256, DOI: 10.1016/j. tourman.2018.12.005.

Lund, K. A., 2013: Experiencing nature in nature-based tourism, Tourist Studies 13 (2), 156-171, DOI: 10.1177/1468797613490373.

Lundmark, L., Müller, D. K., 2010: The supply of nature-based tourism activities in Sweden, Tourism 58 (4), 379-393.

Margaryan, L., Fredman, P., 2017: Natural amenities and the regional distribution of nature-based tourism supply in Sweden, Scandinavian Journal of Hospitality and Tourism 17 (2), 145-159, DOI: 10.1080/15022250.2016.1153430. 
Natek, K., Žumer, J., Ogrin, D., Topole, M., Hrvatin, M., Gabrovec, M., 1993: Geomorfološka inventarizacija Kraškega roba, GIAM ZRC SAZU, Ljubljana.

Ogrin, D., Mužina, D., 2005: Pokrajinskoekološke značilnosti območja med Kavčičem in Tinjanom, in: Meje in Konfini: Rakitovec, vas kulturnih, družbenih in naravnih prepletanj (ed. Rožac-Darovec, V.), ZRS, Koper, 289-332.

Placer, L., 2007: Kraški rob: geološki prerez vzdolž AC Kozina - Koper, Geologija 50 (1), 29-44.

Turk, R., 2012: Zavarovana območja, in: Geografija stika Slovenske Istre in Tržaškega zaliva (ed. Ogrin, D.), GeograFF 12, Znanstvena založba Filozofske fakultete, Ljubljana, 273-289.

Wall-Reinius, S., Bäck, L., 2011: Changes in visitor demand: Inter-year comparisons of Swedish Hikers' characteristics, preferences and experiences, Scandinavian Journal of Hospitality and Tourism 11 (1), 38-53, DOI: 10.1080/15022250.2011.638207.

Øian, H., Fredman, P., Sandell, K., Sæpórsdóttir, A., Tyrväinen, L., Jensen, F., 2018: Tourism, nature and sustainability: A review of policy instruments in the Nordic countries, DOI: 10.6027/TN2018-534.

\section{Sources}

Slovenian Environment Agency, 2019: Atlas okolja, http://gis.arso.gov.si/atlasokolja/profile.aspx?id=Atlas_Okolja_AXL@Arso.

Statistical Office of the Republic of Slovenia, 2019: Population by sex, municipalities and settlements, https://www.stat.si/StatWeb/News/Index/8135. 


\title{
Chapter 7 \\ Development of tourism and second homes in the area of Sviščaki in southwestern Slovenia
}

\author{
Gregor Kovačič, Miha Koderman
}

\section{Abstract}

The hamlet Sviščaki is located in the Municipality of Ilirska Bistrica and is one of the largest mountainous second home areas in southwestern Slovenia. It lies in the close vicinity of Veliki Snežnik Mountain (1,796 $\mathrm{m}$ a.s.l.), the highest mountain in southern Slovenia. In this chapter, we present the development of Sviščaki in the context of the tourism development on Snežnik Plateau. We analyse the current condition of tourist infrastructure, while focusing on spatial analysis of second homes and other communal and tourism infrastructure in Sviščaki. We also evaluate future perspectives for the tourism development of Sviščaki according to the Municipal Detailed Spatial Plan for the Sviščaki Tourist Centre. Spatial analysis of second homes was carried out with the help of the Real Estate Registry and the Public Insight into Real Estate website, which is managed by the Surveying and Mapping Authority of the Republic of Slovenia. The evaluation of the future development of the area as a tourist centre was based on professional documents related to the process of implementation of the aforementioned spatial plan for the Sviščaki Tourist Centre.

Key words: second homes, tourism development, protected area, geography, Sviščaki, Snežnik, Ilirska Bistrica, Slovenia 


\section{Introduction}

The hamlet Sviščaki is located in the Municipality of Ilirska Bistrica and represents one of the largest second home settlements in the region of Notranjska (Gosar, 1987, 258), as well as in southwestern Slovenia. Sviščaki is not an independent settlement, rather it is integrated into the settlement Snežnik, which extends over $95 \mathrm{~km}^{2}$, together with the hamlets Gomanci and Mašun, as well as individual cottages on Snežnik Plateau that belong to foresters, hunters, or vacationers. In the wider area of Snežnik Plateau, there are also other second home settlements, for example in Rakov Škocjan, Gorenje Jezero, and Leskova Dolina.

Snežnik Plateau is a high and forested karst plateau located in the south of Slovenia; it is most often discussed together with the neighbouring and somewhat lower area of Javorniki. Considering the altitude and the topographical features of land relief, the best name that has emerged for the unified area of Snežnik and Javorniki is Snežnik-Javorniki Plateau (Snežniško-javorniška planota). Geographers tend to use various names for this area. Klemenčič (1959), Melik (1960), Lovrenčak (1976) and Gams (1986) called it the Snežnik-Javorniki Mountain Range (Snežniš̌ko-javorniš̌ko pogorje) or Mountains (gorovje), while Lovrenčak (1976) also used the names Snežnik Mountain Range (Snežniško pogorje) and Snežnik-Javorniki Plateau (Snežniško-javorniška planota). Melik (1960) named the whole area Snežnik; Gams (1983), Perko and Orožen Adamič (1998) as well as Senegačnik (2012) called it Javorniki and Snežnik, while Gams, Kladnik, and Orožen Adamič (1995) also used the names Snežnik and Javorniki.

These different names indicate the evident existence of two orographic toponyms, where Javorniki occupies the northern part of the region, while Snežnik Plateau or Snežnik extends to the south (Zupančič, 1998, 334). The borderline separating them runs through dry valleys and larger karst depressions between Knežak, Mašun, Leskova Dolina, and Loško Polje. In the northeast, Snežnik Plateau is delimited by Cerknica Polje and Lož Polje, while in the west and southwest, it descends across steep slopes into the valley of the Reka River, and continues into the large wooded area of Gorski Kotar in Croatia further to the south (Kovačič, 2001; 2003). The core of Snežnik Plateau, where we find the Sviščaki second home settlement, is a high area ranging from 1,200 to $1,796 \mathrm{~m}$ a.s.l., which is the altitude of the Plateau's highest peak: Veliki Snežnik (Klemenčič, 1959). The total area of the predominantly wooded and mostly uninhabited Snežnik-Javorniki Plateau is $458 \mathrm{~km}^{2}$ (Zupančič, 1998, 334). 
The area is known for extensive forests and represents an important protected area, which is included in the Natura 2000 directive. Since 2017, part of the extensive forest complex in this protected area has been part of the transnational UNESCO World Heritage List, under the category of Ancient and Primeval Beech Forests of the Carpathians and Other Regions of Europe (UNESCO, 2019).

The aim of this paper is to present the development of the second home settlement Sviščaki in the context of tourism development on the Snežnik Plateau by analysing the current state and establishment of the tourist centre with a focus on spatial analysis of the holiday dwellings, other community infrastructure and tourist facilities in Sviščaki, and evaluating plans for the future tourist development of Sviščaki in the framework of the Municipal Detailed Spatial Plan for the Tourist Centre Sviščaki (hereinafter OPPN Sviščaki) (Development Center Planiranje, 2018a; 2018b; Romih et al. 2018; Official Gazette of the Republic of Slovenia 62, 2019).

The spatial analysis of the holiday dwellings was performed with the help of the Real Estate Registry and the Public Insight into Real Estate portal, managed by the Surveying and Mapping Authority of the Republic of Slovenia. Assessment of the tourist centre's future development possibilities was carried out on the basis of technical documents related to the procedure of approval of the OPPN Sviščaki (Development Center Planiranje, 2018a; 2018b; Romih et al., 2018) and the Ordinance on the Municipal Detailed Spatial Plan for the Sviščaki Tourist Centre (Official Gazette of the Republic of Slovenia 62, 2019).

\section{Development of tourism in the wider area of Sviščaki}

The development of tourism in the wider area of Sviščaki can be divided into two periods.

\section{Development in the interwar period}

The beginning of tourism in Sviščaki is associated with the period after World War I, when the Snežnik-Javorniki Plateau fell under the control of the Kingdom of Italy almost in its entirety. The Italian government extensively supported the construction of mountain huts in the Snežnik area due to the vicinity of border with the Kingdom of Serbs, Croats, and Slovenes (later the Kingdom of Yugoslavia), in addition to encouraging the construction of military and semi-military facilities and 
connecting roads (Čeligoj, 2019a). These mountain huts were built by the Italian Alpine Club (CAI-Club Alpino Italiano). In September of 1925, the Rijeka section of the CAI built the largest mountain hut in the east of the Kingdom of Italy in Sviščaki; the hut was named Rifugio Gabriele d'Annunzio, $1242 m$ (Čeligoj, 200oa). Veliki Snežnik was becoming an ever more popular day trip destination attracting numerous locals and other visitors, and from that moment on Sviščaki became the central starting point for ascending the peak.

In Ilirska Bistrica, the local branch of the Alpine Association of Slovenia (established in 1907) was still active at the time, but Italian authorities attempted to hinder its activities and pressured mountaineers to join the Rijeka chapter of the CAI (Čeligoj, 20oob). In 1926, the mountaineering subsection of the Rijeka-based CAI was founded in Ilirska Bistrica, which the locals, however, tended to ignore for the most part (Čeligoj, 200oa). The mountain hut in Sviščaki was not the first hut in the area of Snežnik, and the ruins of the first hut are still visible at the time of writing. It was built by the Littoral Branch of the Trieste German and Austrian Alpine Club (Wraber, 200o) on the eastern side of Veliki Snežnik in 1874. In 1914, mountaineers from Bistrica built the hut Vilharjeva koča $v$ Crnem dolu on the ruins of the old cottage a little west of Sviščaki, in the frost pocket of Črni Dol; the hut was, however, forcibly confiscated by Italian authorities in 1927 and handed over to the Rijeka chapter of the CAI (Čeligoj, 20oob).

Some other mountain huts were constructed in the interwar period in the area of Snežnik which no longer exist today, for example the shelter Capanna Angheben and the mountain hut Rifugio Guido Rey on Klanska Polica, which was organised and run like a hotel (Čeligoj, 2019a; 2019b). In order to provide a supply of drinking water on a limestone karst plateau without any available sources of surface water, reservoirs for drainage water were also built, in addition to military and civilian outposts; there are two such reservoirs in Sviščaki. Sviščaki, Klanska Polica (with three supplied huts) and Črni Dol also turned into the "skiing centres" on Snežnik Plateau over time (Čeligoj, 2019c); skiing competitions were organised there occasionally in the past, including competitions in ski jumping (Čeligoj, 2019C; 2019d; 2019e). In this era, the majority of skiers were inhabitants of Rijeka, who usually travelled to Ilirska Bistrica by train and then took lorries to reach the outposts (Čeligoj, 2019c). 


\section{Post-war restoration of mountaineering and the renovation of mountain huts}

Only the hut Vilharjeva koča in Črni dol survived World War II intact, while other mountain huts were demolished; nothing but the walls remained of the burnt-down hut in Sviščaki. The mountaineers of Ilirska Bistrica restructured the commercial premises of the former mountain hut Rifugio Gabriele d'Annunzio, 1242 m, in the period between 1948 and 1951, into a new humble hut named Cankarjeva koča $1242 \mathrm{~m}$ pod Snežnikom. In the 1950s, the hut was left deserted, which was the result of vandalism-people who were not from the area were regularly breaking in and stealing supplies (Čeligoj, 200oc).

At the end of the 1950 and the beginning of the 196os, Sviščaki became increasingly interesting regarding the prospects of tourism and recreation, as snow-rich winters inspired people to take part in winter sports. This provided the impetus for the construction of the first holiday homes in 1963, undertaken by different companies from Ilirska Bistrica (more on this in chapter Development of the second homes in Sviščaki), while, simultaneously, construction works were started for a new mountain hut in Sviščaki: Planinski dom na Sviščakih, which was publicly opened in 1968 (Čeligoj, 2oood). Later, the mountain hut was renovated several times; for the last time, to a greater extent, in 1983, when plumbing fixtures as well as electricity and sanitary fittings were added in an extension, and in 1993, when a mobile phone connection became available (Mountain Hut Sviščaki, 2019; Alpine Association of Slovenia, 2019a).

An important milestone in the development of mountaineering in the area of Snežnik was the construction of a mountain hut on Veliki Snežnik, which was built upon the ruins of a former Italian anti-aircraft lookout post. The construction started in 1958 and was finished in 1961, after the shelter Zavetišče na Velikem Snežniku 1796 m was officially closed down (Čeligoj, 20ooe). In the years that followed, the shelter was extended with additional premises and, in 1977, it was significantly expanded and renovated; in the 1990s, the water supply installations and a telephone connection were also added. At the end of the 199os, the shelter was renamed to Koča Draga Karolina na Velikem Snežniku (179o m) (Čeligoj, 20oof). The cottage offers 20 shared beds and 8 beds in individual rooms, as well as 80 seats in the dining hall (Alpine Association of Slovenia, 2019b). In 2007, the kitchen was renovated, a retaining wall was built, the well and chimney were reconstructed, a protective fence was put up around the shelter, and the win- 
dows and most doors were replaced; in 2009, a more efficient solar power station was constructed and electrical installations in the cottage were renovated (Jaksetič, 2009).

The beginning of the 1990s also brought important political and socio-economic changes with the disintegration of the Socialist Federal Republic of Yugoslavia. A new international border was established between the former Yugoslav federal republics of Slovenia and Croatia and free mobility of mountaineers and hikers across the newly established border was now formally limited to the border crossings that were set on the main roads connecting the two countries.

\section{Development of skiing in Sviščaki}

The wider area of Sviščaki does not only have a long tradition as a popular hiking resort (especially from spring to autumn); since the second half of the 1960s, Sviščaki has been a significant area in terms of winter sports and recreation. The development of "contemporary" organised skiing in Sviščaki began in 1967 when a skiing division was established in the local Alpine Association, and only a year later the unaffiliated Skiing Club Snežnik was founded (Ski Club Snežnik, 2019a), which started constructing ski runs in Sviščaki. In 1968 and 1969, the first ski run was built by involving volunteers and the military, and a motorised ski lift was acquired (Ski Club Snežnik, 2019c).

The year 1969 witnessed the organisation of the first ski course with 120 participants (Ski Club Snežnik, 2019b), while the first competitions and courses for skiing instructors followed in the next few years. In the 19711984 period, the so-called "Snežnik Cup" was organised annually at the end of the skiing season in May-a spectacular skiing competition starting from the very top of Snežnik (Ski Club Snežnik, 2019d). In 1972, a more efficient electrically-operated stand-alone ski lift was introduced, after electricity was brought to Sviščaki (Ski Club Snežnik, 2019c). Simultaneously, a smaller ski hut was built by the side of the ski slope and the first snow machines were acquired. The development of demand for skiing in Sviščaki quickly exceeded what the club could offer, which is why the management and organisation of the ski centre were taken over by the Municipality of Ilirska Bistrica (Ski Club, 2019c).

In 1985, a less steep ski run was created beside the main one, and two more ski runs as well as another ski lift were also added. The latter turned out to be unprofitable, as the ski run happened to be situated on the sunny 
side of the mountain. This sealed the complete image of the skiing centre with four ski runs, a total length of 1.5 kilometres and the surface of 5.7 hectares (Slovenian Forest Service, 2013) as well as two ski lifts with a capacity of up to 1,330 skiers per hour (Vesenjak, 2010).

\section{Condition of the mountaineering facilities and other tourist infrastructure in Sviščaki}

As of the middle of 2019, the restaurant of the mountain hut in Sviščaki seats 38 , while the tables in front of the building seat from 80 to 100 people, and the dormitory offers 11 shared beds. There is also free parking available in front. Toilet facilities and a washroom with cold water are available in the extension; the restaurant and dormitory rooms are heated via central heating (Alpine Association of Slovenia, 2019a). The hut as a whole is heated by wood-burning stoves, and potable water is supplied from the hut's own drainage water reservoir (200 $\mathrm{m}^{3}$ volume), which had been built to supply the shelter Rifugio Gabriele d'Annunzio, $1242 \mathrm{~m}$ (Fig. 1). Before entering the system, water is further purified using filtration and UV disinfection.

The mountain hut only records roughly 50 overnight stays per year, which indicates a lack of demand for this kind of vacation accomodation (Čosić, 2019). While this may also be partly the result of inappropriately furnished accommodation facilities, which are currently suitable only for an overnight stay and do not offer many comforts for those who might wish to stay longer than a single night. The majority of overnight guests come here in the summer months (especially in August) and in winter, when the frequency of visits depends heavily on weather conditions (i.e. if conditions allow for sledding). On average, the hut hosts approximately 10,000 visitors annually (Čosić, 2019); the lower number of visits in the winter months in the last few years is related to the fact that the ski facilities have been out of service since 2014 (Kalc Furlanič, 2015).

Due to several successive snow-light winters and the unwillingness of the municipality to invest large resources into the deteriorating ski lift machinery, which is no longer safe and should be fully replaced and renovated, the municipality has not posted any public calls for firms interested in gaining the concession to manage the ski resort since 2015 (Kalc Furlanič, 2015). Before 2014, the ski runs operated only two weeks, on average, and without artificial snow it was impossible to achieve commercial viability. Artificial production of snow, with which the skiing season could be prolonged, is associated with considerable investment pertaining to the con- 


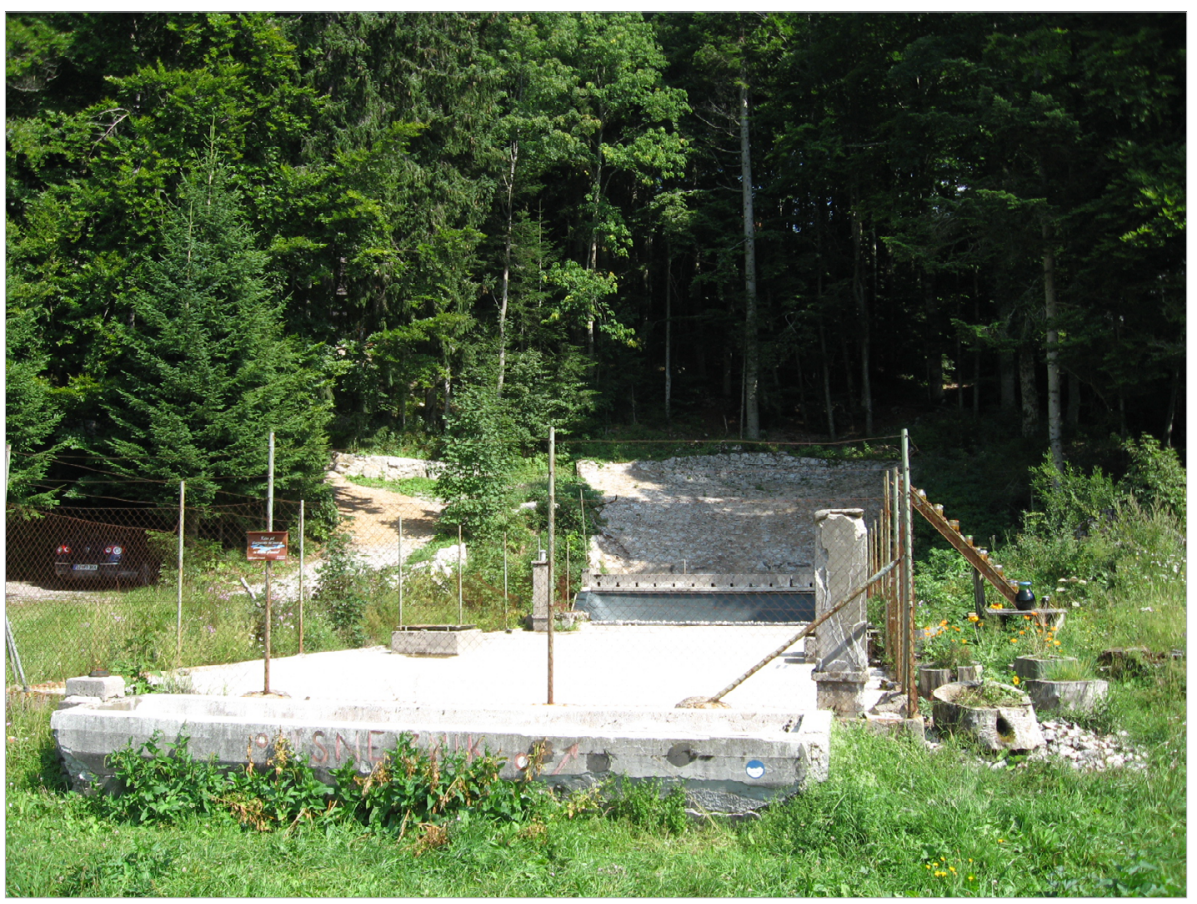

Fig. I A drainage water reservoir, built in the period of Italian occupation Photo by Gregor Kovačič, 2019

struction of basins for retaining precipitation water and snowmaking facilities (Francek Ivović, 2015). Furthermore, the existing skiing facilities and infrastructure are deteriorating, and the ski runs are becoming overgrown by shrubs.

These facts shed some doubt on whether it makes any sense to attempt to re-establish or further develop skiing tourism in Sviščaki, especially considering the trend of increasing air temperatures due to global warming. Regarding winter forms of outdoor recreation, sledding, recreational cross-country skiing, and hiking seem like more realistic options. Hikers can follow numerous forest trails in the vicinity of Sviščaki and across Snežnik Plateau.

In 2019, the mountain hut was in the process of renovation. The investment of around $€ 120$,ooo consisted of a non-refundable European grant for energy-saving building renovations in the amount of $€ 63,000$, added to the owner's own contribution (the owner is the Snežnik Alpine Club, based in Ilirska Bistrica). The hut will be raised by a meter and rooms with sever- 
al beds will be furnished, while the outside image of the hut will stay the same. The hut will offer 19 beds in four rooms with proper sanitary facilities (Francek Ivović, 2018b; Kirn Vodopivec, 2019a; 2019b).

The visitors can park their vehicles in the car park on the eastern side of Sviščaki. The reconstruction of an approximately seven-kilometre section of the nearby state road (completed in November 2019) included the reconstruction of embankments and retaining walls, the implementation of loading ramps for felled timber, and the installation of steel protective rails (Kirn Vodopivec, 2019a).

\section{Development of the second homes in Sviščaki}

The construction of the mountain hut and the development of skiing gave rise to the popularity of Sviščaki, which gave rise to new possibilities for the development of a smaller tourism and recreational centre. With the assent of the Municipality of Ilirska Bistrica, the first holiday huts were built by the local companies Lesonit, Topol, Transport, Ilirija, etc. in the 1960s and were intended for the companies' employees to use for vacation (even before the new mountain hut was finished), although Sviščaki were still without electricity at the time (Čeligoj, 20ood). In 1967, the Municipality of Ilirska Bistrica passed The Ordinance of the Development Plan for the Area of Sviščaki (1967) and The Rules on the Implementation of the Development Plan for the Area of Sviščaki (1967), and thus defined the Sviščaki area as a construction land zone, intended for the construction of second homes, which accelerated the building of houses.

The holiday settlement Sviščaki (an agglomeration of second home dwellings) spreads over an area of approximately 8 hectares (Slovenian Forest Service, 2013). The first houses were built at the edge of a clearing by the mountain hut on Veliki Sviščaki (Fig. 2). The construction of houses soon spread from the forest clearing towards the gravel road that runs to Mali Sviščaki-where we find most new construction. These are located somewhat higher, above the bottom of the shallow doline, with temperature inversion typically occurring in the colder part of the year. There is an $18.5 \mathrm{~km}$ state road leading from the largest centre in the vicinity, Ilirska Bistrica, to Sviščaki. In the last decade, the number of inhabitants in the settlement of Snežnik, of which Sviščaki is a part, varied between 17 and 25 . There were 19 people living permanently in the settlement in 2019, 10 of which were male (Statistical Office of the Republic of Slovenia, 2019). 


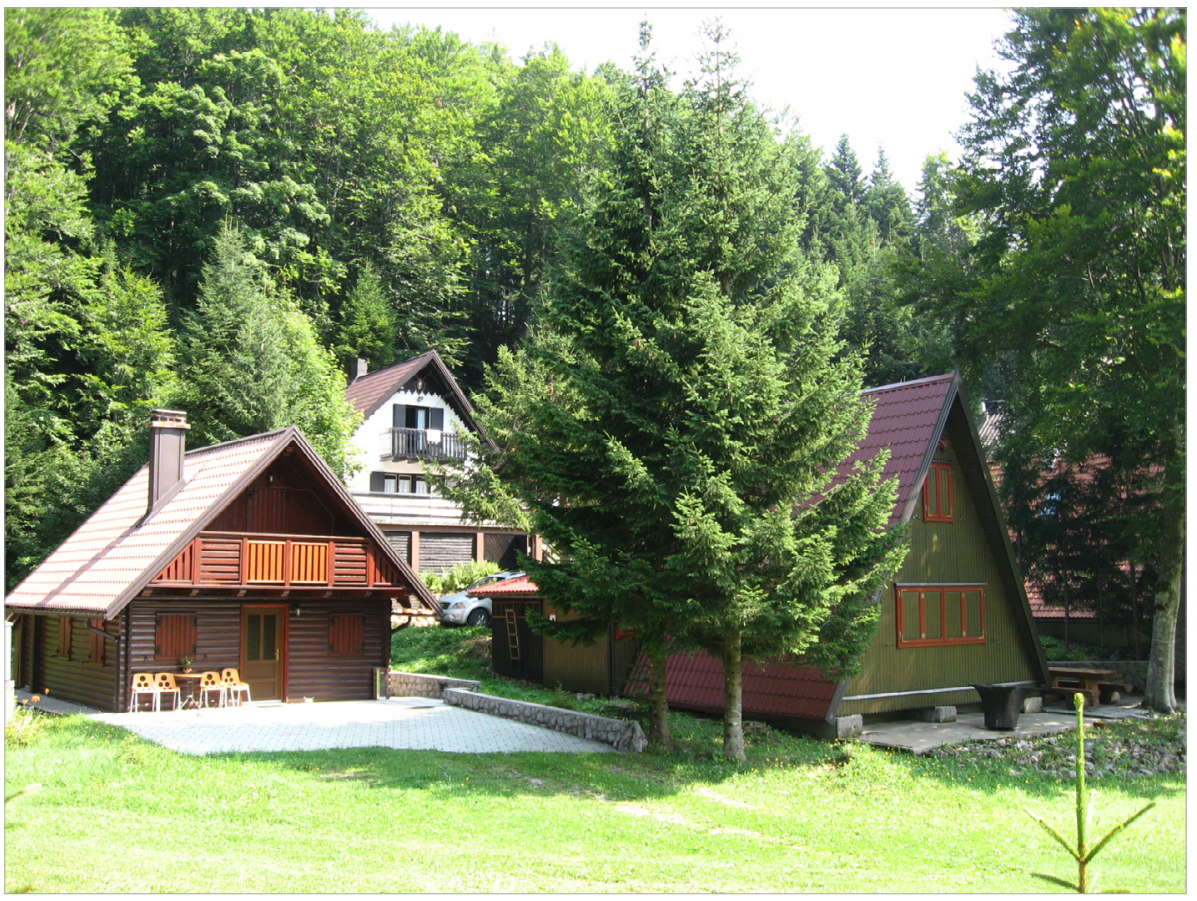

Fig 2. Second homes in Sviščaki

Photo by Gregor Kovačič, 2019

The owners of the second homes are merely tenants on the land upon which their buildings stand. The owner of the majority of the woods in Sviščaki (Slovenian Forest Service, 2013), and the six forested parcels where these dwellings are located, is the Municipality of Ilirska Bistrica, with whom the owners entered into long-term leases with a maturity of up to 99 years (Ferko, 2013). In Sviščaki, no zoning has ever been made that would allow each building to occupy its own (privately-owned) parcel of land. Locations of holiday cabins are sequentially numbered in the order in which they had been built, and parcels were leased in the same order (Ferko, 2013).

With new tenants or those whose contracts have expired, the municipality enters into contracts with a five-year maturity (Municipality of Ilirska Bistrica, 2019). The municipality charges 128 euros annually for the lease of a land parcel, regardless of its size (Ferko, 2013). The ownership structure of the holiday establishments shows that in 2016, there were 13 legal entities registered as tenants, while the rest of the tenants were natural 
persons. Of the latter, 23 lived in the municipality of Ilirska Bistrica and 58 came from other Slovenian municipalities. In 2016, the tenants also included 6 Italian citizens and 2 Croatian citizens (Brižan, 2016).

The occupancy of the holiday houses in Sviščaki is low and they are empty much of the year (Francek Ivović, 2017; 2018a; Mulec, 2018) - around 20 of them seem to be in permanent use, while some are even deteriorating (Čošić, 2019). The manager of the mountain hut and some of the owners of the holiday houses in Sviščaki believe that there is demand for accommodation in the holiday huts, but not many have been offered for this purpose on the market (Francek Ivović, 2017; Čosić, 2019). On Booking.com (the most famous online accommodation provider) we find only one person offering to rent out a holiday home in Sviščaki. The majority of the cabins' owners perceive their property as a family heirloom that they do not wish to share with others.

Nonetheless, some people like the idea of offering their holiday hut for vacationers to rent while they aren't using it. They are partly forced to consider this option because of the high costs of maintaining the facilities and renovation in an area where summers are short, while empty houses also decay faster. In 2017, the Tourist Cooperative Sviščaki was established for this purpose, bringing together property owners who would like to rent their holiday houses to tourists. Accommodation would be offered under the name of the Dispersed Hotel Sviščaki. The co-operative would be responsible for the rental of houses, administration, and all operational activities related to rental and the actual accommodation of guests, which would relieve the owners of the burden of such obligations entirely (Francek Ivović, 2017; 2018a; 2018b; Mulec, 2018).

The expansion of the second home settlement was, however, not accompanied by site development services which the municipality should have provided. The owners of the holiday homes thus tackled the provision of utilities for their establishments individually. As a matter of fact, holiday dwellings require quite extensive infrastructure, as one needs to secure a water supply, the disposal of municipal sewage and proper waste disposal, set up electricity, ensure sufficient transport accessibility, as well as the access to mobile telephone services and the internet (Cigale, 2009). Sviščaki got electricity in 1972 when a $20 \mathrm{kV}$ electrical power line was installed, connecting the settlement to Ilirska Bistrica (Slovenian Forest Service, 2013). Two transformer stations were built that meet current power consumption 
(Vesenjak, 2010). The buildings' owners had to co-finance individual electric connections to their holiday homes.

A potable water supply was obtained by most of the houses' owners by constructing reservoirs for harvesting rainwater, either on the roof or beside their holiday huts, while quality drinking water is supplied by various convenient water filtration systems. Some houses are supplied with drinking water from the rainwater reservoir that was constructed in the period of Italian occupation, found at the edge of the clearing (Fig. 1); the owners of the holiday cabins maintain the reservoir without aid from the Municipality. The disposal of waste water is managed through the use of septic tanks. On the basis of the facilities' age and the general assessment of the condition of septic tanks in Slovenia (Tavčar, 2015), we can infer that most septic tanks are still flow-through systems, which can be problematic for the fragile underground waterways that are characteristic for karst landscapes.

There is no land-line telephone network, but mobile telephone service is available. During the heating season, which tends to be very long, most of the holiday houses use wood heating, while some also use fuel oil or electricity for heating. During special weather conditions, solid fuel heating can cause the air pollution in the area of Sviščaki, especially in the clearing where there is occasionally a minor temperature inversion in the shallow doline. The negative impact of air pollution is somewhat mitigated by the holiday houses' location in the forest.

Waste collection is organised in the car park on the weastern side of Sviščaki, where waste is collected separately in large containers in the manner that is uniformly prescribed for the whole region of the Municipality of Ilirska Bistrica (Fig. 3). Strong winds or wild animals will often scatter trash from the containers if they are not properly closed.

\section{Spatial analysis of the holiday dwellings in Sviščaki}

In this research, we analysed data on the buildings of the Sviščaki settlement. As mentioned in the introduction, the data were obtained from the Real Estate Registry of the Surveying and Mapping Authority of the Republic of Slovenia, which has proved to be a useful source of information for geographical research (for example, Komac et al., 2012; Koderman and Salmič, 2013; Salmič and Koderman, 2013; Koderman, 2014; 2017; Koderman and Pavlič, 2019). In order to acquire additional information regarding individual buildings, and numbers on the parcels and proprietorship, we also consulted the Public Insight into Real Estate website, which 


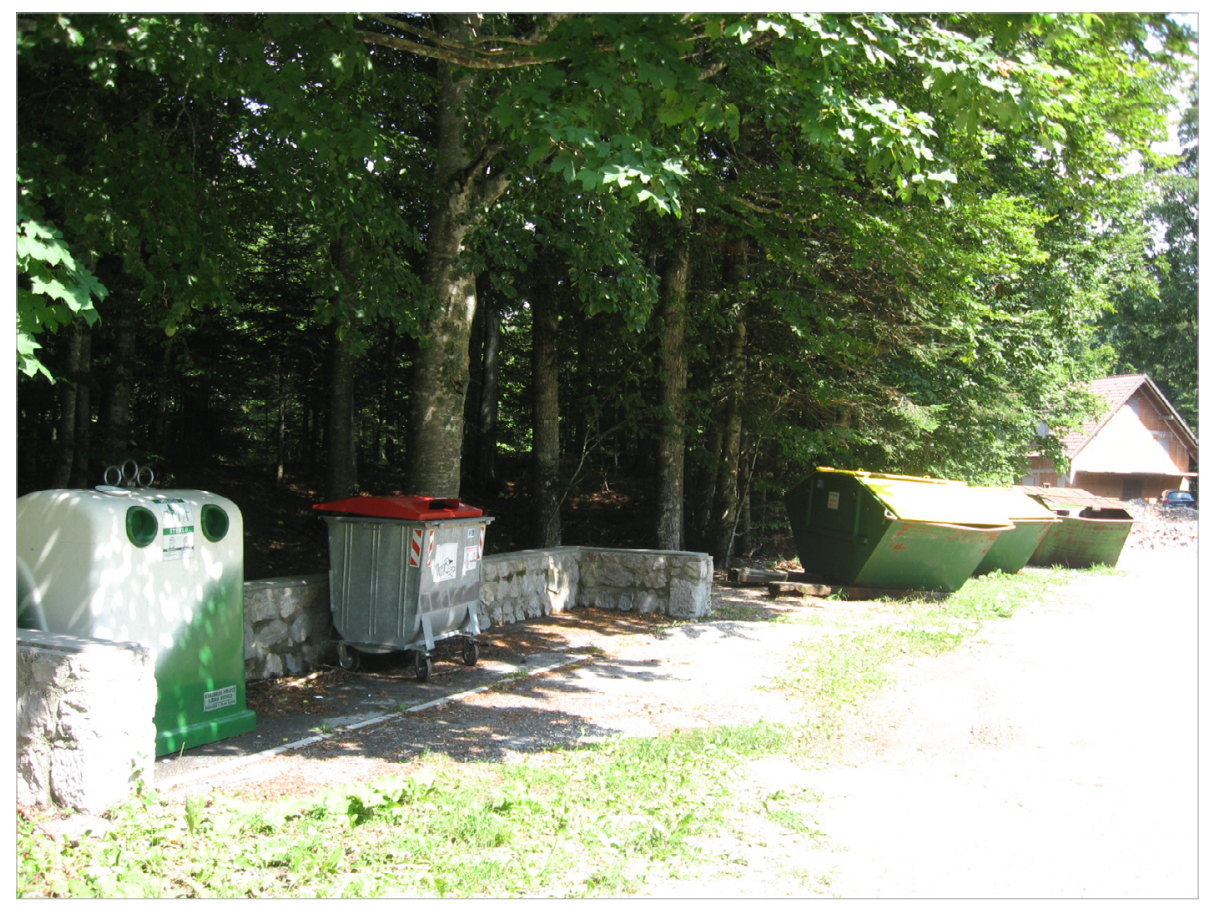

Fig. 3 The waste collection area in Sviščaki

Photo by Gregor Kovačič, 2019

is also managed by the Surveying and Mapping Authority of the Republic of Slovenia.

From the dataset of cadastral municipality 2508, Snežnik, we eliminated all the units which were not located in the area of Veliki and Mali Sviščaki (those with parcel numbers 2049/30, 2049/32, 2055/19, 2055/21, 2058/2, and 2067/14), in the first phase of research. Out of the total of 162 units in the cadastral municipality, we identified 100 buildings as the subjects of further analysis. In the second stage, we eliminated 4 more buildings that were not holiday dwellings: the mountain hut; two commercial establishments recorded as garages in the Real Estate Registry; and the transformer station.

The subject of the detailed spatial analysis was now narrowed to 96 autonomous buildings, i.e. holiday houses. Many of these have accompanying woodsheds, terraces, drainage water reservoirs, improvised car parks, as well as proper access roads. The mountain hut and 12 holiday houses have house numbers, while none of the accompanying facilities are regis- 
tered in the building cadastre. Almost all of the buildings are single dwelling holiday houses, there are only two multi-apartment houses (one has two and the other three apartments) (Surveying and Mapping Authority of the Republic of Slovenia, 2019).

The external design of the holiday houses varies in terms of roof slope and overall design. Some buildings are entirely made of bricks and have a façade, while others are wholly wooden, which gives the impression of a lack of architectural coordination in terms of construction. The reason for this state of things can be found in the very vaguely written Rules on the Implementation of the Construction Plan for the Area of Sviščaki (1967), as well as lack of required know-how or a sense of how construction should be managed in such areas; the situation can also be attributed to the lack of state control. Some investors took advantage of this and constructed buildings outside of the permitted size-instead of small holiday huts, large tourism establishments appeared in some cases (Ferko, 2013; Fig. 4). Individuals, sometimes in cooperation with each other, also arranged ac-

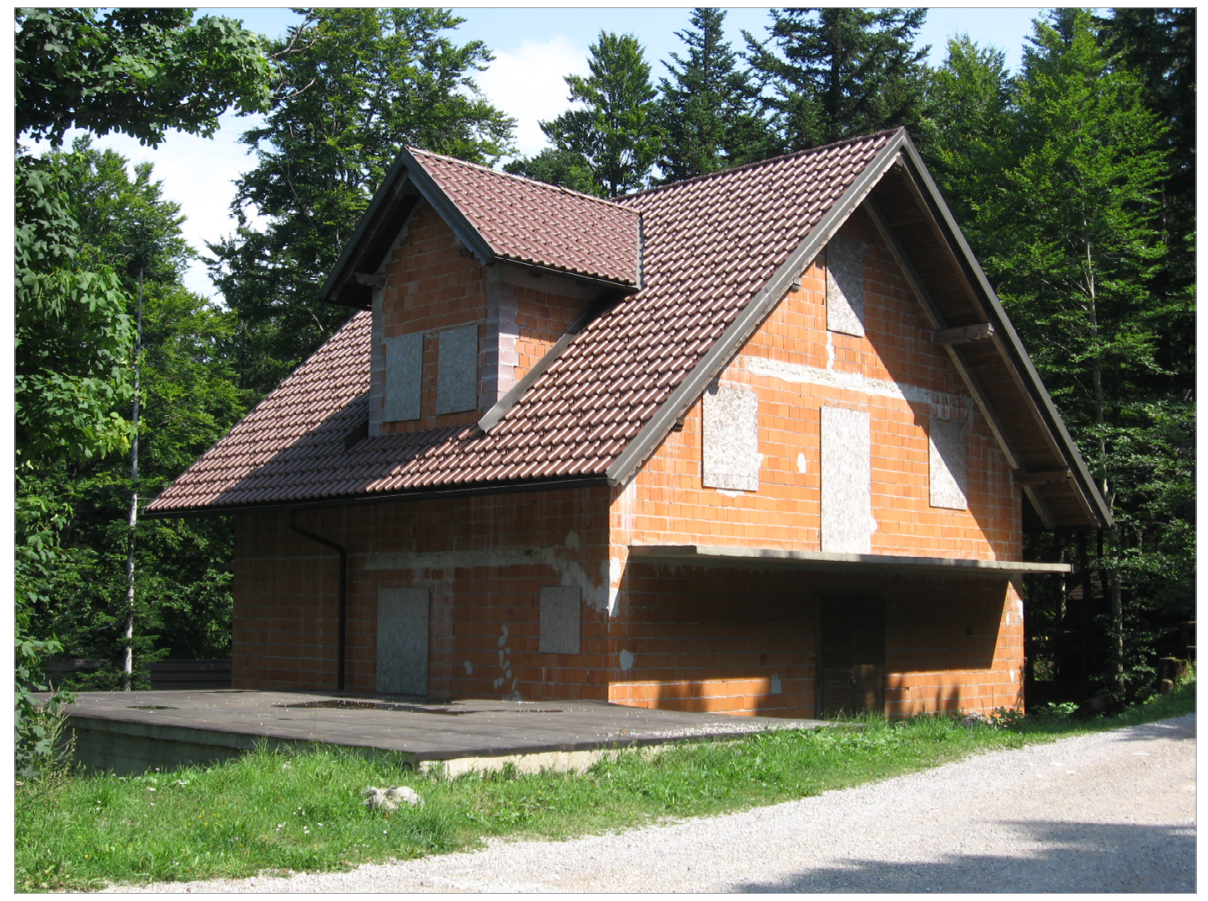

Fig. 4 An example of a holiday house which has remained unfinished for almost a decade Photo by Gregor Kovačič, 2019 
cess to their houses and the outside of the houses according to their needs (parking places, constructed terraces, woodsheds, etc.).

The number of the holiday houses has quickly risen over the decades and, due to inadequate spatial plans, buildings were built without a systematic distribution throughout the area and without architectural uniformity, which has resulted in inefficient use of space; the edges of the settlement are also vaguely defined. Nonetheless, the location of the holiday houses in the forest somewhat mitigates its generally bad image, which is not suitable in terms of urban and architectural planning.

According to data from the Real Estate Registry, the first holiday house was built in 1958 (Fig. 5). In the 1960s, 13 new dwellings appeared on the edges of the clearing beside the mountain hut, and the same number of dwellings was also constructed in the following decade. The average floor area of these buildings ranged between 46.6 and $46.8 \mathrm{~m}^{2}$. In the 1980s, the construction of holiday dwellings spread and flourished; as many as 37 new

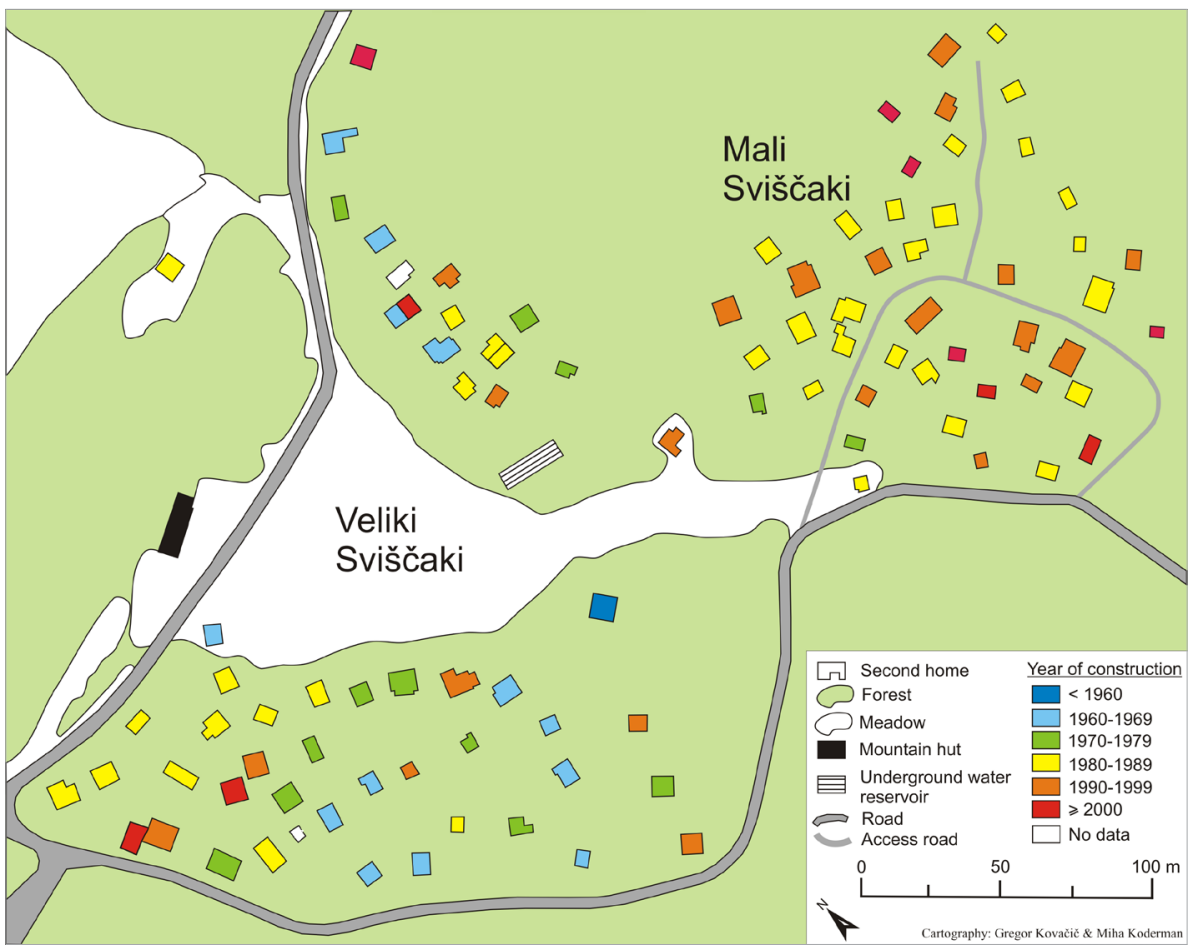

Fig. 5 The age structure of the holiday dwellings in Sviščaki in 2019 Source: Surveying and Mapping Authority of the Republic of Slovenia, 2019 
buildings with an average floor area of $43 \mathrm{~m}^{2}$ were built in the area of Veliki and Mali Sviščaki during this period. In the 1990s, the intensity of construction somewhat dropped, as only 22 new buildings were built, followed by another 10 in the first decade of the $21^{\text {st }}$ century (the most recent was constructed in 2005). The average floor area of the buildings constructed in the $1990 \mathrm{os}$ is $55.5 \mathrm{~m}^{2}$, while the average floor area of those constructed after the year 2000 is a mere $33 \mathrm{~m}^{2}$. We only identified three buildings with a floor area of less than $20 \mathrm{~m}^{2}$ (the smallest buildings measured only 15 or 14.5 $\mathrm{m}^{2}$ ), while the floor area of eight buildings exceeded $90 \mathrm{~m}^{2}$ (the two largest had 111 and $120 \mathrm{~m}^{2}$ of the floor area). The floor area of holiday dwellings is shown in Fig. 6.

What should be added to the data on the buildings' average floor area is the fact that both the Real Estate Registry as well as the Public Insight into Real Estate website revealed that most holiday buildings (57 out of 96 buildings - there was no information on 9 buildings) have at least two or

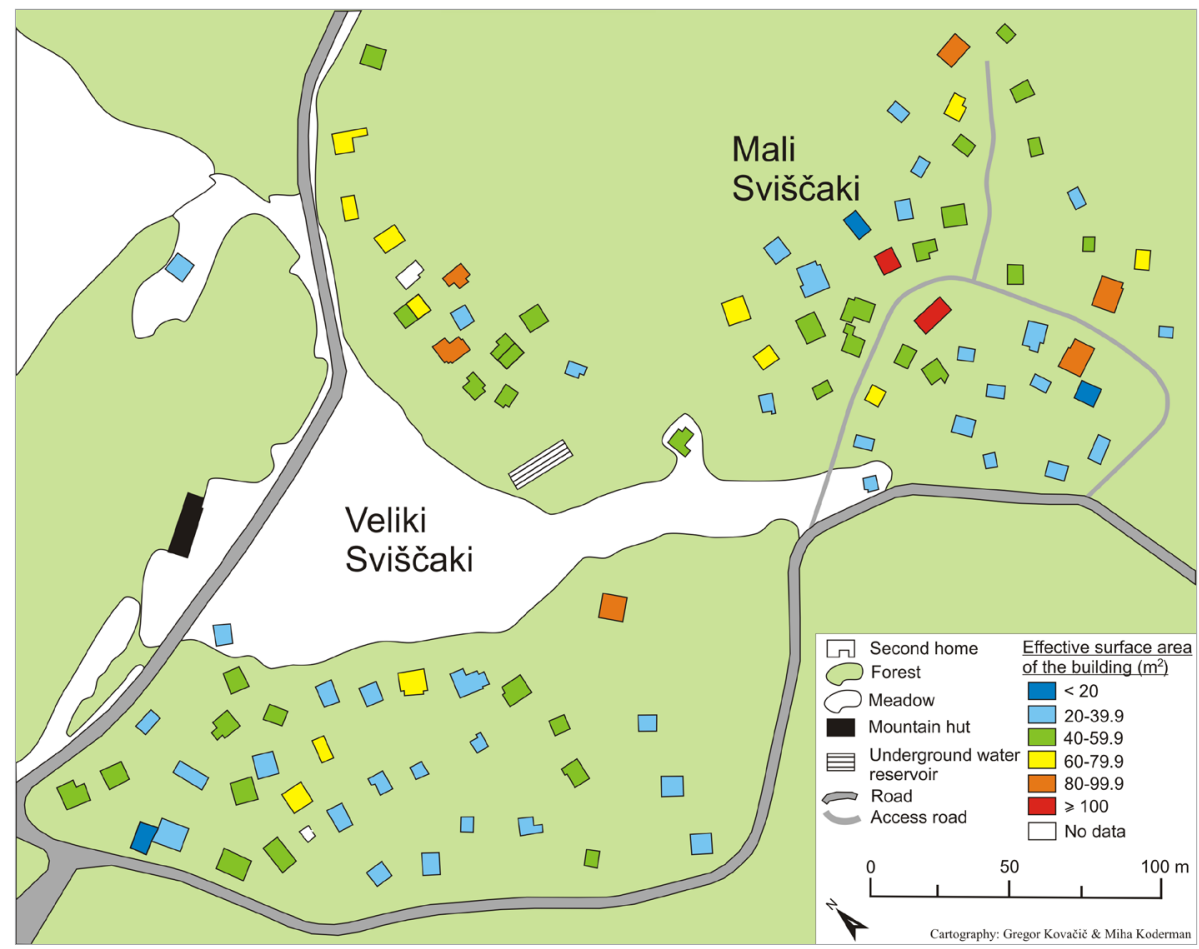

Fig. 6 The size of the holiday dwellings in Sviščaki in relation to their floor area in 2019 Source: Surveying and Mapping Authority of the Republic of Slovenia, 2019 
three stories. Most buildings thus have a much larger living area in reality, as the floor plan represents only the area which is primarily intended as living space (the cellar and the attic usually do not count as living space in this sense). Additional reasons for the large differences between the buildings' actual floor area and documented floor area could stem from real-estate speculation-in 2006 and 2007, the Surveying and Mapping Authority of the Republic of Slovenia carried out an inventory of real estate as a starting point for preparing the Real Estate Registry and the Law on Real Property Tax. By stating a smaller area, some owners of the holiday houses might be attempting to avoid paying higher real estate taxes. Although the aforementioned Law has not yet entered into force, as the Constitutional Court of Slovenia stopped it in 2014, it is expected to enter into force in the near future.

\section{Tourism development plans for the wider area of Sviščaki}

The development of the whole tourism-recreational area Sviščaki, which includes the holiday settlement, is outlined by the OPPN Sviščaki, which entered into force on September $26^{\text {th }}, 2019$ and was officially published in the Official Gazette of the Republic of Slovenia on October $18^{\text {th }}, 2019$ (Development Center Planiranje, 2018a; 2018b; Romih et al., 2018; Official Gazette of the Republic of Slovenia 62, 2019). The area of planning in the OPPN Sviščaki encompasses two units of spatial planning, namely: SV o1, which is designated as a special area for tourist premises, intended for hotels, bungalows, and other facilities needed for accommodation and the general tourism supply, the surface area of which is approximately 14.98 hectares; and SV 02, conceived as an area of green space, intended for recreation and relaxation, as well as sports, the surface area of which is around 29.88 hectares (Romih et al., 2018; Fig. 7).

Crucial spatial plans to be implemented in the area of SV 01 are:

- the elimination and construction of a new mountain hut or the renovation of the existing one, the construction of a hotel with outbuildings (two interconnected buildings), and four bungalows;

- the construction of eleven new holiday houses as well as the renovation and remodelling (reconstruction) of existing ones;

- the construction of a restaurant and sanitary facility as well as sport areas; 
- $\quad$ the construction of a multi-purpose sport and recreation facility with a swimming pool, which would serve as a natural ice rink in the winter;

- $\quad$ arranging the existing multi-purpose grass pitch for ball games and a toboggan run, a children's playground, a bocce court, and a picnic and camping area;

- the restoration, rehabilitation, and improvement of the existing network of access roads, as well as cycling and pedestrian paths;

- the creation of a new car park for vehicles (passenger cars, tourist coaches, campers);

- the renovation, rehabilitation, and extension of facilities of economic public infrastructure, consisting of the power grid, telecommunications network, network for the distribution of water, network and facilities for waste water collection and treatment, and network and facilities for differentiated waste collection and disposal (Development Center Planiranje, 2018a; Official Gazette of the Republic of Slovenia 62, 2019).

Spatial planning to be implemented in the area SV o2 are:

- the removal of several existing facilities (the existing economic facilities near ski lifts, the existing ski lifts), and the construction of new ski lifts (ski draglines and chairlifts) near the existing and planned ski runs (4 appliances) with accompanying service buildings;

- the planned gastronomic and other related facilities for the requirements of maintenance and supply of ski runs;

- the renovation, restoration, and improvement of existing ski slopes (1st and 2nd phases);

- the renovation, restoration, and improvement of the network of cross-country skiing tracks (along the route of the existing road to Mašun);

- the creation of fitness trails, an adventure park, and picnic areas;

- the renovation, restoration, and improvement of the network of existing roads, cycling paths, and walking trails (footpaths, themed routes, rest spots, etc.);

- the construction of a new reservoir for collecting precipitation for artificial snow production on the ski runs; and

- the renovation, restoration, and improvement of facilities pertaining to public infrastructure (the same as for SV o1) (Development 


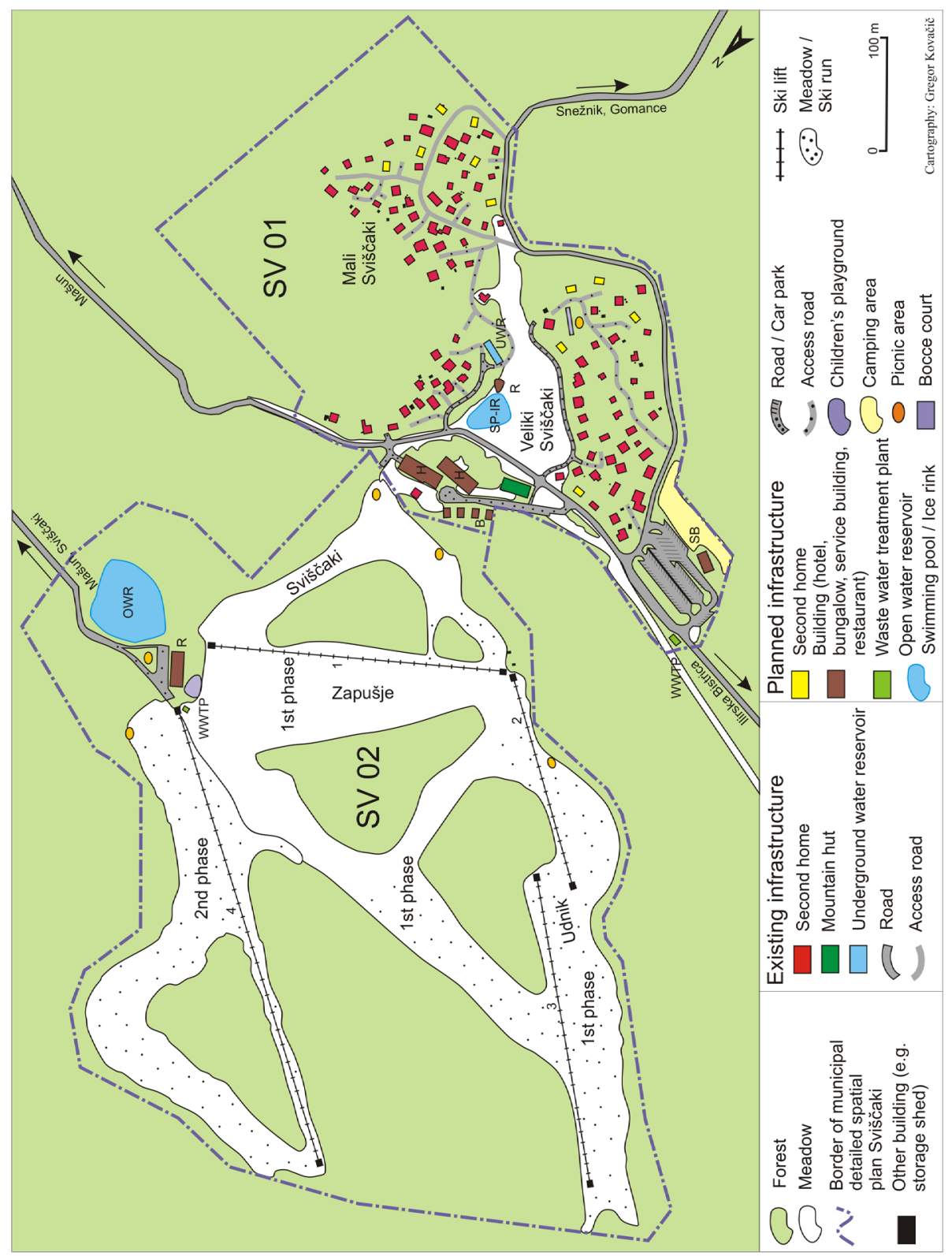

Fig. 7 The area of Sviščaki with existing and planned tourism infrastructure Source: Romih et al. 2018 
Center Planiranje, 2018b; Romih et al., 2018; Official Gazette of the Republic of Slovenia 62, 2019).

In many aspects, the plan for developing the tourism and recreational area of Sviščaki seems very ambitious and in some regards inconsistent with the natural conditions offered by the area of Sviščaki from the perspective of tourism. Some spatial planning authorities have already pointed this out, in regard to the guidelines of the draft by the OPPN Sviščaki. The spatial plan, among other things, envisions the renovation and even expansion of skiing areas, with the restoration of skiing tourism. Ski slopes are envisioned to be upgraded in two stages.

The first stage would encompass the renovation, restoration, and improvement of the existing ski slopes Sviščaki, Zapušje, and Udnik, along ski lifts 1, 2, and 3, covering approximately 9 hectares, while in the second stage, a new ski run would be constructed near ski lift 4, covering an area of approximately 4 hectares (Romih et al., 2018; Official Gazette of the Republic of Slovenia 62, 2019). These plans seem to be unattractive for investors, due to the relatively low altitude of Sviščaki (and lack of sufficient natural snow) and the absence of surface water for artificial snowmaking, which would ensure a longer skiing season-meaning that the infrastructure for artificial generation of snow would have to be constructed from scratch.

Plans for building totally new tourism infrastructure (extension or construction of a new mountain hut, hotel, hotel annex, bungalows, new restaurant buildings, an adventure park, a swimming pool/skating rink, etc.) also relate at least partly to winter forms of outdoor tourism and, to an even greater extent, to summer tourism. However, it is questionable whether these investments will materialise in the future. Implementation appears more realistic for some of the planned tourist infrastructure, like the construction of new holiday houses, arranging of picnic areas, car parks, a camping area, and the corresponding economic facilities, the theme park, urban equipment (elements for sitting, lights, orientation signboards, and information signs), etc.

The OPPN Sviščaki (Official Gazette of the Republic of Slovenia 62, 2019) should usher in many positive changes. Of major importance are the plans for integrated development of the area on the basis of the proper economic public infrastructure, and the conditions and guidelines for architectural and landscape design in connection to the external furnishing of buildings which prescribes the use of natural stone, concrete, classical plas- 
ter, and wood, while also requiring that façades must be in natural hues of stone and wood for all new construction and future renovations (Romih et al., 2018). This measure will significantly improve the general appearance of the second home settlement. The earliest possible adoption of the document is also welcomed by the owners of the holiday dwellings in Sviščaki, as this will finally allow them to regularise the status of land which their holiday houses stand on, as currently not one of the plots with a building has an official number. The owners would like to purchase the land on which their houses are located, though they are also willing to enter into a long-term lease agreements with the Municipality of Ilirska Bistrica (Ferko, 2013). Soon, every holiday house will stand on its own land parcel.

The OPPN Sviščaki envisages the maintenance of the potable water supply in its existing form, using existing rainwater capturing systems (Romih et al., 2018, 35), which is appropriate considering the amount precipitation in the area, and the existing infrastructure and technical knowhow regarding rain/snow water collection. Construction of a regional water supply system from water sources at a lower altitude is not cost-effective at present. We estimate, however, that the drinking water supply is not a limiting factor for future tourism development in Sviščaki.

A major new gain for the holiday settlement will be the construction of a sewage network and a central underground water treatment plant with the capacity of 500 population equivalent (PE), to which all the existing and planned facilities in Sviščaki will have to be connected. This implies that the septic tanks in the holiday houses will lose their function. The motorhome area in the central car park will also be connected to the sewage system (Romih et al., 2018, 35). A separate system is planned for the disposal of run-off rain water. The drainage water from the buildings' roofs would be retained and used for watering plants or as drinking water; from the surfaces of larger tourist establishments (hotel, bungalows, the large mountain hut) and the hard-paved surfaces surrounding them as well as car parks, water would be released into the reservoir planned for snow production (Romih et al., 2018, 36). It is not known how the disposal of run-off rain water would be carried out in the event that the construction of a reservoir for snow production (for the ski runs) does not take place. The planned improvements also include a small water treatment plant with the capacity of $50 \mathrm{PE}$, intended for the restaurant envisioned next to the ski run, which could, however, also be replaced with a watertight septic tank (Romih et al., 2018, 35; Official Gazette of the Republic of Slovenia 62, 2019). 
The OPPN Sviščaki (Official Gazette of the Republic of Slovenia 62, 2019) also envisions an arrangement of a central car park in the area of the current car park in the western part of Sviščaki, with approximately 90 parking spaces for cars, 10 spaces for campers, and up to 5 spaces for buses. The plan also includes 25 parking spaces in the area of the mountain hut, the planned bungalows, and the hotel. Parking spaces for cars near holiday houses will be arranged as part of functional land as garages or outside car parks, i.e. one to two parking spaces per building (Romih et al., 2018).

The main energy product for heating buildings is still wood, according to the OPPN Sviščaki (Official Gazette of the Republic of Slovenia 62, 2019), which can be complemented with fuel oil and electricity. It is possible to arrange shared heating for multiple buildings, but this is not required. The planned power supply does not foresee any major investments, however, the plan allows for the installation of photovoltaic cells on the exposed parts of roofs and façades, and some elements of urban equipment. Routes for the electronic communication network are also envisaged (Romih et al., 2018).

The OPPN Sviščaki (Official Gazette of the Republic of Slovenia 62, 2019) also envisions an improved management of waste collection and disposal; waste will be collected by each establishment separately, and deposited at technically-suitable fixed spots where containers for differentiated waste collection will be placed (Romih et al., 2018, 36). As we have already mentioned above, the current state of waste collection in Sviščaki is insufficient in terms of environmental standards, which is why the proposed solution will significantly contribute to the better image of the area, as long as there is consistent compliance with the rules and required standards. In line with the OPPN Sviščaki, containers will have to be airtight so that the smell of waste will not spread, and they will be enclosed with a fence so that animals will not be able to access them. The same goes for freestanding waste bins (Uljan, 2018, 4), though we have certain doubts whether it makes sense to install these, instead of just relying on a simple rule requiring guests to either take their waste back to the valley, which would apply to day-trippers visitors, or to dispose of it in designated areas.

\section{Conclusion}

The second homes in the area of Sviščaki, which experienced the most intense level of development in the 1980s, caused significant changes in the natural environment of Snežnik Plateau over the course of several dec- 
ades. The buildings constructed in the sensitive karst landscape, where we find numerous natural treasures and ecologically significant areas that are protected as part of Natura 2000, are problematic in a number of aspects, among which we can highlight the uncontrolled disposal and treatment of waste water and the failure to comply with the traditional architectural patterns.

Although the adoption of The Ordinance on the Construction Plan for the Area of Sviščaki (1967) and The Rules on the Implementation of the Construction Plan for the Area of Sviščaki (1967) brought crucial spatial planning documentation to the area, the regulatory prescriptions were defined too broadly to prevent architectural-physiognomic imbalances and the unbridled construction of new facilities. On the other hand, we can only imagine the chaos that might have ensued without the aforementioned ordinances, in terms of the development of the second home settlement.

By adopting the OPPN Sviščaki (Official Gazette of the Republic of Slovenia 62, 2019), the Municipality of Ilirska Bistrica intends to offer this area new opportunities for development. The spatial plan also discusses an increase in the number of holiday dwellings in places where they are currently already relatively concentrated. We believe that it would be wiser to approach the renovation of the existing buildings that are in the process of decay; and considering all the large-scale development plans, we need to be, above all, conscious of the significant role of this unique natural area, which could suffer irreparable damage in the event of reckless and unsustainable interventions.

\section{References}

Brižan, M., 2016: Razvojne možnosti turizma na Sviščakih z okolico z vidika okoljskih učinkov, Graduation Thesis, Univerza na Primorskem, Fakulteta za humanistične študije, Koper.

Cigale, D., 2009: Turizem in rekreacija kot dejavnika okoljskih obremenitev, in: Okoljski učinki prometa in turizma $v$ Sloveniji (eds. Špes, M., Ogrin, D.), Znanstvena založba Filozofske fakultete Univerze v Ljubljani, Ljubljana, 86-105.

Čeligoj, V., 20ooa: Planinstvo med obema vojnama, in: Knjiga o Snežniku (ed. Čeligoj, V.), Planinsko društvo Snežnik, Ilirska Bistrica, 64-68.

Čeligoj, V., 20oob: Planinstvo, posvečeno Snežniku, in: Knjiga o Snežniku (ed. Čeligoj, V.), Planinsko društvo Snežnik, Ilirska Bistrica, 56-60. 
Čeligoj, V., 20ooc: Prvo desetletje po svobodi, in: Knjiga o Snežniku (ed. Čeligoj, V.), Planinsko društvo Snežnik, Ilirska Bistrica, 69-70.

Čeligoj, V., 2oood: Društvo zgradi planinski dom na Sviščakih, in: Knjiga o Snežniku (ed. Čeligoj, V.), Planinsko društvo Snežnik, Ilirska Bistrica, 78-80.

Čeligoj, V., 20ooe: Leta prvih gradbenih podvigov, in: Knjiga o Snežniku (ed. Čeligoj, V.), Planinsko društvo Snežnik, Ilirska Bistrica, 73-76.

Čeligoj, V., 20oof: Koča na Snežniku dobi današnji izgled, in: Knjiga o Snežniku (ed. Čeligoj, V.), Planinsko društvo Snežnik, Ilirska Bistrica, 91-94.

Gams, I., 1983: Geografske značilnosti Slovenije, Mladinska knjiga, Ljubljana.

Gams, I., 1986: Pokrajinska ekologija, Filozofska fakulteta, Ljubljana.

Gams, I., Kladnik D., Orožen Adamič, M., 1995: Naravnogeografske regije Slovenije, in: Krajevni leksikon Slovenije (ed. Perko, D.), DZS, Ljubljana.

Gosar, A., 1987: Geografski vidik razvoja počitniških bivališč na Notranjskem in Primorskem, in: Notranjska: zbornik 14. zborovanja slovenskih geografov, Postojna (ed. Habič, P.), Zveza geografskih društev Slovenije, Postojna, 251-264.

Klemenčič, V., 1959: Pokrajina med Snežnikom in Slavnikom. Založba ZRC SAZU, Ljubljana.

Koderman, M., Salmič, S., 2013: Prebivati ob “jezeru bliz’ Triglava”: Prostorska analiza počitniških bivališč v občini Bohinj, in: Gorenjska v obdobju glokalizacije (eds. Mrak, I. et al.), Znanstvena založba Filozofske fakultete Univerze v Ljubljani, Ljubljana, 111-125.

Koderman, M., 2014: Spatial Analysis of Second Homes in the Municipality of Piran, Academica turistica 7 (2), 179-191.

Koderman, M., 2017: Second Homes in Protected Areas of Slovenia - The Case of the Triglav National Park, in: Tourism in Protected Areas of Nature in Serbia and Slovenia (eds. Filipović, D. et al.), University of Belgrade, Faculty of Geography, Belgrade, 87-100.

Koderman, M., Pavlič, M., 2019: Second homes in the Slovenian Alps with special emphasis on the municipality of Bovec, Hrvatski geografski glasnik 81 (1), 61-81, DOI: 10.21861/HGG.2019.81.01.03.

Komac, B., Zorn, M., Kušar, D., 2012: New possibilities for asses sing the damage caused by natural disasters in Slovenia - The case of the Real Estate Record, Geografski vestnik 84 (1), 113-127. 
Kovačič, G., 2001: Pokrajinska ogroženost in ukrepi za zaščito kraškega izvira Bistrica. Annales: anali za istrske in mediteranske študije - Series Historia Naturalis 11 (1), 93-104.

Kovačič, G., 2003: Kraški izviri Bistrice (JZ Slovenija), Annales: anali za istrske in mediteranske študije - Series Historia Naturalis 13 (1), 111-120.

Lovrenčak, F., 1976: Zgornja gozdna meja v Kamniških Alpah v geografski luči (v primerjavi s Snežnikom), Založba ZRC SAZU, Ljubljana.

Melik, A., 1960: Slovensko primorje. Slovenija: geografski opis 2, Slovenska matica, Ljubljana.

Perko, D., Orožen Adamič, M., 1998 (eds.): Slovenija, pokrajine in ljudje, Mladinska knjiga, Ljubljana.

Salmič, S., Koderman, M., 2013: Prostorska analiza počitniških bivališč v Občini Kranjska Gora, Geografski vestnik 85 (1), 9-24.

Senegačnik, J., 2012: Slovenija in njene pokrajine, Modrijan založba, Ljubljana.

Wraber, T., 200o: Koča na Kranjskem Snežniku, in: Knjiga o Snežniku (ed. Čeligoj, V.), Planinsko društvo Snežnik, Ilirska Bistrica.

Zupančič, J., 1998: Javorniki in Snežnik, in: Slovenija: pokrajina in ljudje (eds. Perko, D., Orožen Adamič, M.), Mladinska knjiga, Ljubljana, 334-341.

\section{Sources}

Alpine Association of Slovenia, 2019a: Planinski dom na Sviščakih (1242 m), https://www.pzs.si/koce.php?pid=171 (09. 08. 2019)

Alpine Association of Slovenia, 2019b: Koča Draga Karolina na Velikem Snežniku (179o m), https://www.pzs.si/koce.php?pid=168 (o9. 08. 2019)

Čeligoj, V., 2019a: Značka planinske koče na Klanski polici, Snežnik 1935, Portal kamra, digitalizirana kulturna dediščina slovenskih pokrajin, https:// www.kamra.si/album-slovenije/item/znacka-planinske-koce-na-klanski-polici-sneznik-1935.html (o9. o8. 2019)

Čeligoj, V., 2019b: Smučarski vrvež na Klanski polici, 1933, Portal kamra, digitalizirana kulturna dediščina slovenskih pokrajin, https://www.kamra.si/ album-slovenije/item/smucarski-vrvez-na-klanski-polici-1933.html (o9. o8. 2019)

Čeligoj, V., 2019c: Reški smučarji preplavili snežniška pobočja, 1930, Portal kamra, digitalizirana kulturna dediščina slovenskih pokrajin, https:// www.kamra.si/album-slovenije/item/reski-smucarji-preplavili-snezniska-pobocja-1930.html (o9. 08. 2019) 
Čeligoj, V., 2019d: Smučarji na Mašunu, 1932, Portal kamra, digitalizirana kulturna dediščina slovenskih pokrajin, https://www.kamra.si/album-slovenije/item/smucarji-na-masunu-1932.html (o9. o8. 2019)

Čeligoj, V., 2019e: Smučarji na Mašunu, 1932, Portal kamra, digitalizirana kulturna dediščina slovenskih pokrajin, https://www.kamra.si/album-slovenije/item/smucarski-skoki-iz-hrvaske-v-slovenijo-193o.html (09. 08. 2019)

Čošić, J., 2019: Oskrbnica Planinske doma na Sviščakih, Oral source, (o1. o8. 2019)

Development Center Planiranje, 2018a: Občinski podrobni prostorski načrt za turistično središče Sviščaki, dopolnjen osnutek - povzetek za javnost, Razvojni center planiranje, Celje, https://www.ilirska-bistrica.si/mma//2018022708493082/?m= (o8. 08. 2019)

Development Center Planiranje, 2018b: Odlok o občinskem podrobnem prostorskem načrtu za turistično središče Sviščaki, dopolnjen osnutek, Razvojni center planiranje, Celje, https://www.ilirska-bistrica.si/mma//2018022612314973/?m= (o8. 08. 2019)

Ferko, L., 2013: Z načrtom bi “spontano” naselje postalo urejeno, Primorske novice, http://www.primorske.si/Primorska/Srednja-Primorska/Znacrtom-bi--spontano--naselje-postalo-urejeno.aspx (01. o8. 2019)

Francek Ivović, S., 2015: Propada tudi nekoč zelo priljubljeno smučišče Sviščaki, Prvi dnevnik, RTV Slovenija, https://4d.rtvslo.si/arhiv/prvi-dnevnik/174315106 (19. 01. 2015)

Francek Ivović, S., 2017: Turistična oživitev na Sviščakih, Prvi dnevnik, RTV Slovenija, https://4d.rtvslo.si/arhiv/prvi-dnevnik/174510802 (27. 12. 2017)

Francek Ivović, S., 2018a: Na Sviščakih bi odprli razpršeni hotel, Slovenska kronika, RTV Slovenija, https://4d.rtvslo.si/arhiv/slovenska-kroni$\mathrm{ka} / 174537381$ (07. 05. 2018)

Francek Ivović, S., 2018b: Koča na Sviščakih potrebuje prenovo, Poročila, RTV Slovenija, https://4d.rtvslo.si/arhiv/porocila/174585820 (30. 12. 2018)

Jaksetič, D., 2009: Na Snežniku nova sončna elektrarna: več elektrike za planinsko zavetišče, Delo, 4. 7. 2009.

Kalc Furlanč, L. 2015: Bo smučanje na Sviščakih le še oddaljen spomin?, Primorske novice, http://www.primorske.si/Novice/Srednja/-Bosmucanje-na-Sviscakih-le-se-oddaljen-spomin (o4. 02. 2015)

Kirn Vodopivec, K., 2019a: V obnovljen dom na Sviščakih bo kmalu vodila asfaltna cesta, Primorske novice, 15. 7. 2019. 
Kirn Vodopivec, K., 2019b: Po prenovi na Sviščakih tudi prenočišča, Primorske. si., https://www.primorske.si/primorska/srednja-primorska/po-prenovi-na-sviscakih-tudi-prenocisca (01. 08. 2019)

Mulec, S., 2018: Na Sviščakih vzpostavljajo razpršeni hotel, Notranjskoprimorske novice. https://notranjskoprimorske.si/2018/04/na-sviscakih-vzpostavljajo-razprseni-hotel/ (18. 08. 2019)

Municipality of Ilirska Bistrica, 2019: Municipality of Ilirska Bistrica, Oddelek za družbene dejavnosti.

Mountain Hut Sviščaki, 2019: http://www.sviscaki.com/index.php/o-nas (o9. 08. 2019)

Official Gazette of the Republic of Slovenia 62, 2019: Odlok o Občinskem podrobnem prostorskem načrtu za turistično središče Sviščaki.

Romih, R., Toman, T., Teržan, N., Geršak Podbreznik, A., Povalej, I., Šetina, M., Čosič, S., 2018: Občinski podrobni prostorski načrt za turistično središče Sviščaki, dopolnjen osnutek, https://www.ilirska-bistrica.si/ $\mathrm{mma} /-/ 2018022612312966 / ? \mathrm{~m}=(08.08 .2019)$

Slovenian Forest Service, območna enota Postojna, 2013: Gozdnogospodarski načrt gozdnogospodarske enote Okroglina (2013-2022), http://prostor.zgs. gov.si/pregledovalnik/ (10. 08. 2019)

Ski Club Snežnik, 2019a: Kako smo nastali, http://www.sk-sneznik.com/?p=58 (12. 08. 2019)

Ski Club Snežnik, 2019b: Glavne aktivnosti smučarskega kluba, http://www. sk-sneznik.com/?p=59 (12. o8. 2019)

Ski Club Snežnik, 2019c: Prva vlečnica na Sviščakih, http://www.sk-sneznik. $\mathrm{com} /$ ? $\mathrm{p}=62$ (12. 08. 2019)

Ski Club Snežnik, 2019d: Pokal Snežnika in ostala tekmovanja, http://www. sk-sneznik.com/?p=61 (12. o8. 2019)

Statistical Office of the Republic of Slovenia, 2019: Prebivalstvo po velikih in petletnih starostnih skupinah in spolu, naselja, Slovenija, letno, https://pxweb.stat.si/SiStatDb/pxweb/sl/10_Dem_soc/10_Dem_soc__05_prebivalstvo__10_stevilo_preb__25_05C50_prebivalstvo_naselja/o5C5002S.px/ 8 (07. 08. 2019)

Surveying and Mapping Authority of the Republic of Slovenia, 2019: Kataster stavb.

Tavčar, B., 2016: Manj kot pet odstotkov greznic je ustreznih, Delo, http://www. delo.si/novice/okolje/manj-kot-pet-odstotkov-greznic-je-ustreznih.html. 
The Ordinance of the Development Plan for the Area of Sviščaki (Odlok o zazidalnem načrtu za območje Sviščakov), 1967: Uradne objave Primorskih novic, št. 18, Koper.

The Rules on the Implementation of the Development Plan for the Area of Sviščaki (Pravilnik o izvajanju zazidalnega načrta za območje Sviščakov), 1967, Občina Ilirska Bistrica, Ilirska Bistrica, 1967.

Uljan, A., 2018: Zapisnik iz javne obravnave dopolnjenega osnutka OPPN Sviščaki in okoljskega poročila, Občina Ilirska Bistrica, https://www.ilirska-bistrica.si/obcinska-uprava/urejanje-prosto$\mathrm{ra} / 2017102508431955 / 2018052814022586$ (25. 08. 2019)

UNESCO, 2019: World Heritage List, Ancient and Primeval Beech Forests of the Carpathians and Other Regions of Europe, https://whc.unesco.org/en/ list/1133/documents/ (10. 10. 2019)

Vesenjak, P., 2010: Investicijski program z idejno zasnovo za investiranje v turistično infrastrukturo Sviščaki, Hosting d.o.o., Ptuj. 


\section{Chapter 8}

Škocjanski zatok Nature Reserve:

a case study of a protected urban wetland area and tourist attraction

Bojana Lipej, Lovrenc Lipej, Simon Kerma

\section{Abstract}

The creation of Škocjanski zatok is closely connected with a municipal decision to reclaim the area for urban development. After many years of degradation, a civil initiative took over with a vision of protecting this devastated man-made wetland and started the process of renaturation. The outstanding ornithofauna, halophyte vegetation, and other habitats were the main arguments that led to the declaration of protected status of Škocjanski zatok in 1998. The restored reserve has become a quickly developing new destination for ecotourism (attracting responsible visitors and helping to extend the region's tourist season). Different groups also use the area for their purposes, such as elementary and secondary school programmes and universities. Special attention is given to specific interest groups related to nature history, ornithology, arts, crafts, and earth sciences. Properly selected forms of nature-based tourism represent a support activity with a positive effect on the maintenance and promotion of this protected area.

Key words: protected areas, nature-based tourism, ecotourism, Škocjanski zatok Nature Reserve, Slovenia 


\section{Introduction}

Biodiversity is essential for humans because it provides many different goods and ecosystem services. In recent decades, biodiversity and other aspects of natural heritage of Slovenia have been gaining interest and they are among the most important motivations behind tourism visits. In fact, tourism development is growing intertwined with areas that are rich in biodiversity. Ecotourism is, in that regard, the most appropriate type of tourism because it has a relatively minor impact on the environment. Because protected areas represent a basis for public environmental education, and ecotourism in protected nature areas generally takes the form of legitimate activity, they require adequate policy regulation and/or management (Guillemain et al., 2007).

On the short Slovenian coastline, which is approximately $48 \mathrm{~km}$ long, coastal wetlands are of particular interest since they are perceived as important bird diversity hotspots (See: Škornik et al., 1995; Sovinc, 2012). They attract many birdwatchers from all around Europe and other continents. In addition, such wetlands attract many other groups of visitors and are a valuable destination for the organisation of education activities such as field excursions, biology and ecology courses, practical experiments, and so on. At the time of writing, investigation of the significance of marine coastal wetlands for tourism development in Slovenia is lacking (e.g. Jurinčič and Popič, 2009; Sovinc, 2012).

On the other hand, several studies have already illustrated win-win scenarios that can emerge between conservation practices and enhancement of ecosystem services (Chan et al., 2006; Reyers et al., 2012). We can easily consider protected areas to be the hotspots of many ecosystem services (Pueyo-Ros, 2018). They include: provisioning services (food, water, or wood); regulation services that affect the weather, floods, diseases, waste, or water quality; supporting services, such as soil formation, and biodiversity maintenance; as well as cultural services that provide aesthetic or spiritual benefits, or satisfaction in tourism and recreation (Figueroa and Aronson, 2006; Nikodinoska et al., 2015).

Nature-tourism, however, is an important expression of the relationship between nature and societies. Therefore, the aim of this chapter is to discuss the role of a specific protected area and its potential for the responsible development of the appropriate forms of nature-based tourism. 


\section{A case study: Škocjanski zatok Nature Reserve (ŠZNR)}

On the coast, where the Rižana and Badaševica rivers used to flow into the sea, lies Škocjanski zatok Nature Reserve, the last witness to the insular past of the town of Koper (Fig. 1). Today, ŠZNR is encircled by the coastal town of Koper (neighbouring port), the highway and railway, and other (sub)urban areas. It can therefore be considered as urban wetland, according to the Ramsar classification. As it is located in the vicinity of the town of Koper, it belongs to the Koper littoral region and it is also a part of Koper Bay and the Gulf of Trieste (Učakar, 2009).

The area of Škocjanski zatok has a majority of sunny days (up to 2,350 hours per year) and temperatures in the range of $0{ }^{\circ} \mathrm{C}$ to $20{ }^{\circ} \mathrm{C}$ (Ogrin, 1995). The precipitation regime is also sub-Mediterranean, with high precipitation in spring and autumn and low precipitation in the winter and summer (Ogrin, 1995). ŠZNR is the largest brackish wetland in southwest Slovenia, covering 122.7 ha (Šalaja et al., 2007) and a very unique eco-

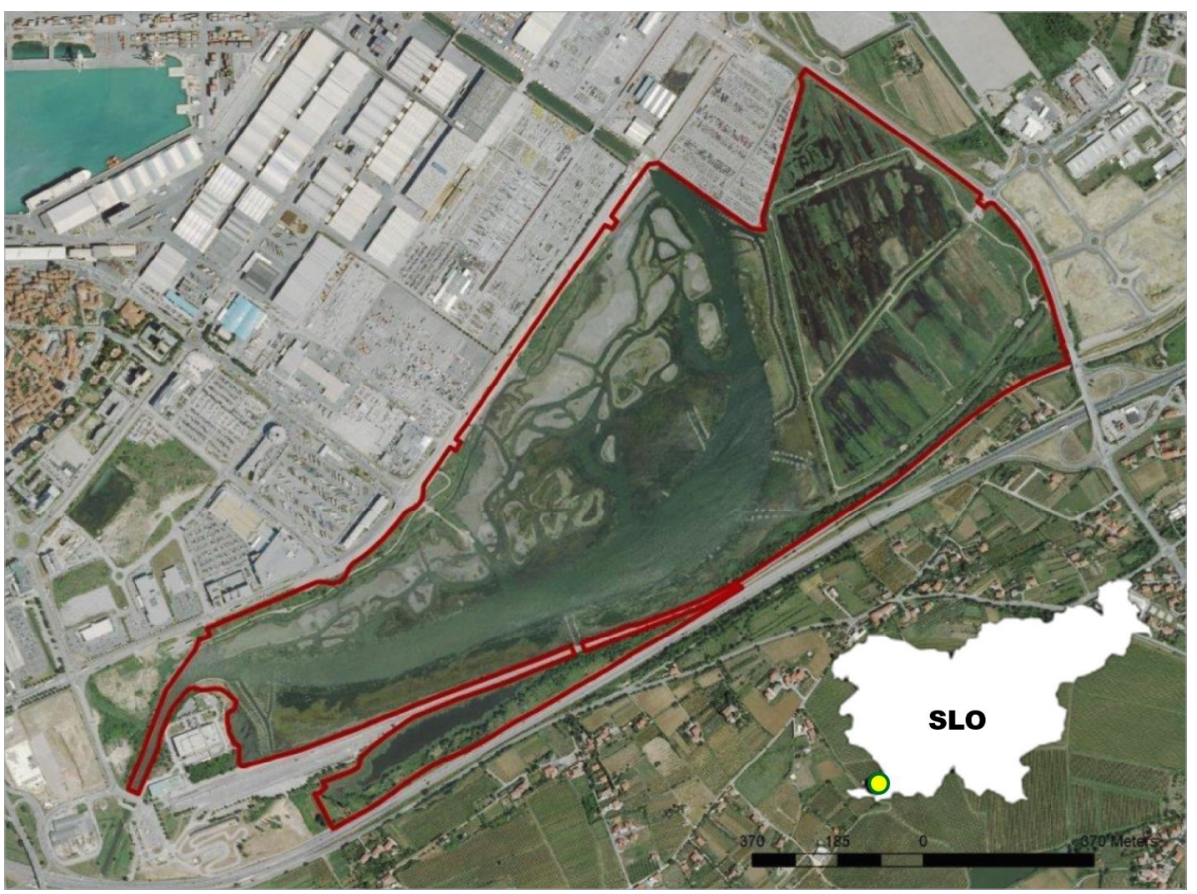

Fig. I Protected area of Škocjanski zatok Nature Reserve and its location in Slovenia Source: DOPPS, 2015 
system. Its unique ecosystem is a product of its proximity to the sea and Mediterranean climate and sub-Mediterranean vegetation, which allows great diversity of plant and animal species, many of them rare and endangered. It is an important European nesting, wintering, and migration site for many bird species.

The protected area is divided into two main parts (Mozetič et al., 2010):

1. a brackish lagoon with nesting islets, mudflats, and saltmarshes which are influenced by tides and overgrown with different types of halophytes; and

2. a freshwater marsh with wet and marshy meadows, open water areas of various depth surrounded by reed beds and thermophilic shrubs.

There are no natural lagoons in Slovenia, therefore the man-made lagoon (i.e. of anthropogenic origin) ŠZNR represents a semi-closed euryhaline and eurytherm habitat.

\section{The creation of Škocjanski zatok}

When the town of Koper started to expand in 1950s, Škocjan Bay was steadily modified into a man-made lagoon, named Škocjanski zatok. Due to anthropogenic activities in the 1970s and 1980s (draining and filling the lagoon, and disposing of various types of waste, from construction material and organic waste to other types of municipal waste), the watery areas of Škocjanski zatok shrank from 230 to 80 hectares (DOPPS, 2007) (Fig. 2). The mobilisation of a civil initiative in the 1990s (Kaligarič et al., 1993), inspired by ornithologists and supported by 7,00o local inhabitants who signed a petition, resulted in the establishment of the protected area. In November 1993, Škocjanski zatok was temporarily declared a natural sight and later, on the basis of an emergency decree issued by the Ministry of Culture in March 1998, the Slovenian Parliament adopted the Škocjanski zatok Nature Reserve Act (1998), which represented the end of many years of conservation efforts to protect Škocjanski zatok (Šalaja et al., 2007).

The former wetland was later consequently restored, renatured, and slightly expanded into today's Škocjanski zatok Nature Reserve. In 2006 and 2007, the restoration of the lagoon and creation of a freshwater marsh at Bertoška bonifika took place in accordance with the LIFE-Nature project "Restoring and conserving habitats and birds in Škocjanski zatok Nature Reserve" (LIFEooNAT/SLO/7226). Moreover, after many years, life re- 


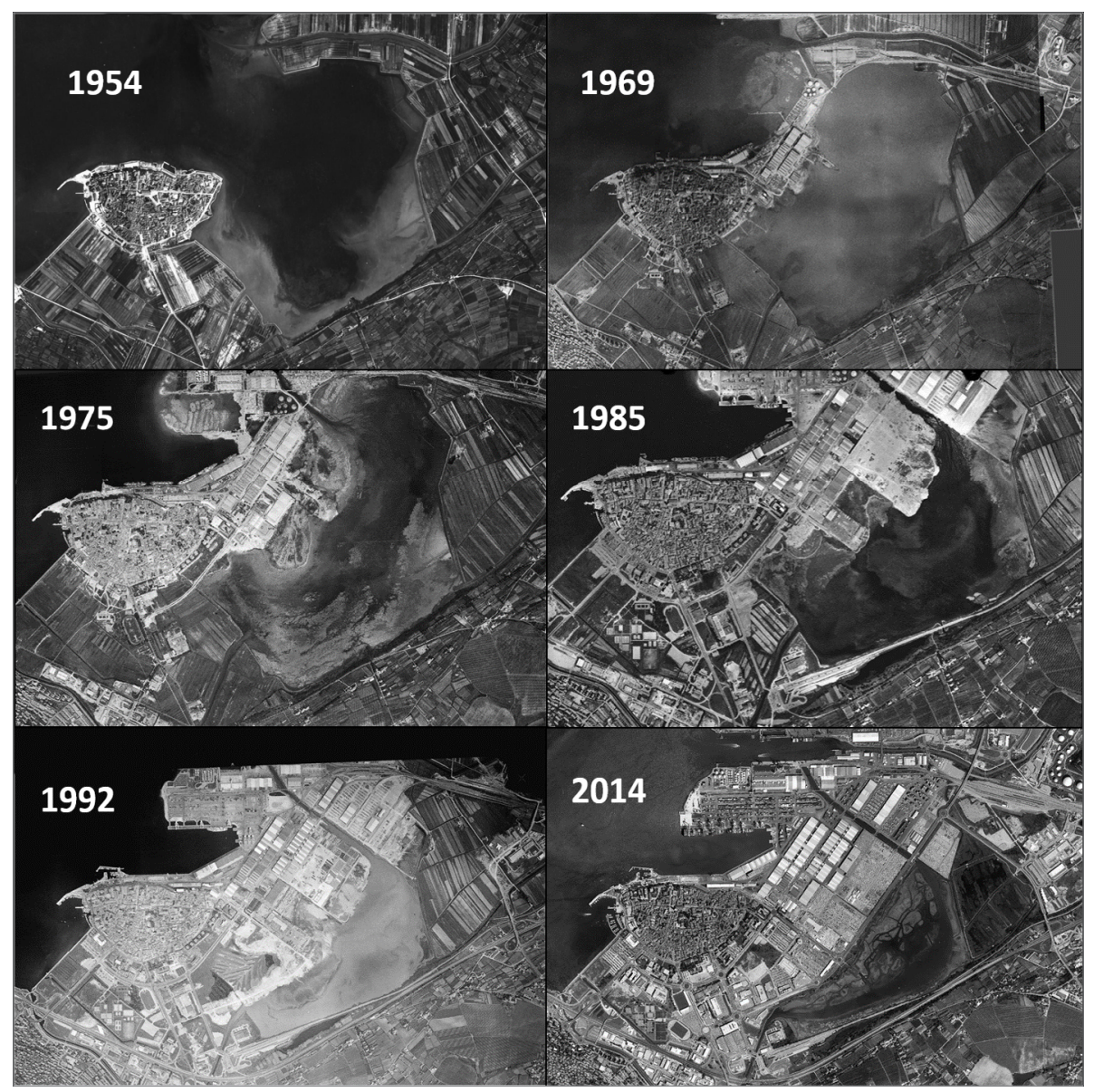

Fig. 2 The evolution from Škocjan Bay (1950) into Škocjanski zatok Nature Reserve (2014) and the reduction of the area

Source: authors according to Surveying and Mapping Authority of the Republic of Slovenia

turned to Škocjanski zatok, which is now thriving with rich marine and brackish flora and fauna (DOPPS, 2007). The reserve is commonly known as "the green heart of the Town of Koper" (Mozetič et al., 2014).

This wetland is especially important in term of biodiversity as it hosts rich fauna and flora and many endangered and vulnerable animal and plant species (41\% of all Slovenian amphibian species, $41 \%$ of all reptile species, over $60 \%$ of all birds observed in Slovenia, and $36 \%$ of all mammals living in Slovenia are present in this area (Mozetič and Šalaja, 2005)). To this end 
it was designated as a Slovenian nature reserve, an ecologically important area (EPO) open to the public, and a Natura 2000 site of Birds and Habitat Directives. Management of ŠZNR is in the hands of the non-governmental organisation Društvo za opazovanje in proučevanje ptic Slovenije - BirdLife Slovenia (DOPPS) (1999-2019). It is the very first case in Slovenia that an NGO was granted a management licence over a protected area (DOPPS, 2015).

ŠZNR is also important as an educational and research laboratory, where many scientists can investigate the characteristics of a northern Adriatic coastal habitat and its properties. For more than three decades, the area has provided an area for the research of many scientists such as ornithologists, botanists, marine biologists, entomologists, nature conservationists, and many others. One of the main concerns has been to ascertain whether the deepening of the central part of the lagoon and its connection with the sea channel was successful. The study of the marine macrofauna of the lagoon after the deepening process showed that the ecological conditions substantially improved. In fact, some studies using the modern approach of biotic indices (Pittaco et al., 2017) confirmed the diversification of marine fauna in the lagoon and incremental increases in the number of feeding guilds. Moreover, this confirms the fact that the abundant macrobenthic fauna is sustaining the wintering bird community. In addition, the planning of artificial muddy islets simultaneously with the deepening of the lagoon proved to be a successful strategy to attract important wetland bird species - which were the main motivation to protect the area.

Due to its vicinity and connection with the harbour Koper (Luka Koper) through the marine channel, the area is susceptible to bioinvasion, e.g. colonisation of alien species. Maritime transport is one of the most recognised pathways for the introduction of alien species into a new environment. Alien organisms, which were able to survive the long journey from the area of origin in the ballast tanks of a ship or on its hull, get released into the new area, i.e. the waters off of Koper. Through the marine channel, they are able to enter the lagoon and cause modifications in the native biota.

It is for this reason that the lagoon of Škocjanski zatok has attracted marine biologists and ecologists to investigate potential colonisation, settlement, and impacts on native biota. Up to the time of writing, many alien species have been detected in the protected area and some of them are already well established in their new environment. Among such alien spe- 
cies, it is worth to mention the bioconstruction species-a sedentary colonial polychaete Ficopomatus enigmaticus, which creates reefs (up to $1 \mathrm{~m}^{2}$ each) in the lagoon. Furthermore, some invasive alien species have been recorded in the lagoon, such as the Japanese oyster Magallana gigas, the clam Arcuatula senhousia, and the alienbubble shell Haminoea japonica (Lipej et al., 2012), however, none of them appear to be having a negative impact on the environment.

In recent years, some studies have also been performed on the effect of climate change on this coastal wetland, especially from the standpoint of sea level rise (Ivajnšič and Kaligarič, 2014; Kaligarič and Ivajnšič, 2014). As was mentioned, the area also attracts a significant number of naturalists and birdwatchers. Moreover, ŠZNR is gradually becoming more and more interesting for the local population; not only for recreationists, but also for enthusiastic groups or individuals, who enjoy spending time in nature. In their research, Brečko Grubar and Kovačič (2011) presented results showing the positive attitude of the Koper Municipality population towards Škocjanski zatok. In spite of some generational differences (in contrast to the younger population, a large share older people remember the lagoon as abandoned area of degradation), the results showed that the local population is familiar with the reasons for the protection of Škocjanski zatok, and is supportive of the protection regime. In general, the locals recognised the reserve as a great contribution to the level of quality of the residential environment in the area (Brečko Grubar and Kovačič, 2011).

\section{Škocjanski zatok Nature Reserve as an attraction for visitors}

After the formal protection and implementation of the renaturation, the area of ŠZNR became increasingly interesting for its visitors. Organised tours for groups became a reality and at the same time, an opportunity for the development of environmentally and ecologically-oriented (sustainable) tourism. Activities and suggestions of how to include ŠZNR into the integrated tourism supply have also taken place. Balažič et al. (2011) identified the potentials of the reserve and its integration into tourism products in Slovenian Istria, including the promotion of environmentally friendly mobility (cycling, arrival at a destination, movement through a destination), and the involvement of cultural heritage, local gastronomy, and produce providers. This continues to be a challenge for ŠZNR management.

However, ŠZNR is oriented toward teaching visitors about nature via experiencing nature (DOPPS, 2016). Controlled nature-based or ecotour- 
ism in ŠZNR began in 2007, when the restoration was completed and an educational nature trail in the freshwater part of the reserve was prepared and opened for visitors (Šalaja, 2016). Larger groups of visitors are guided by skilled employees, while smaller groups or individuals can visit the open nature trail on their own. According to the Škocjanski zatok Nature Reserve Act (1998), entrance to the nature reserve is free of charge, while guided visitation is obligatory for the groups of more than ten and for all school and educational groups (regardless of size). The reserve manager carries out the guided tours upon payment (DOPPS, 2016).

New visitor facilities (visitor centre, observation points, central observation tower, stable for grazing cattle) built in 2015 offer many opportunities for various programmes or events, such as guided tours for lay and professional public, organisation of workshops, lectures, meetings, and conferences. Visitors can visit properly equipped birdwatching observation points (Fig. 3) along the nature trail, together with the $12 \mathrm{~m}$ high central

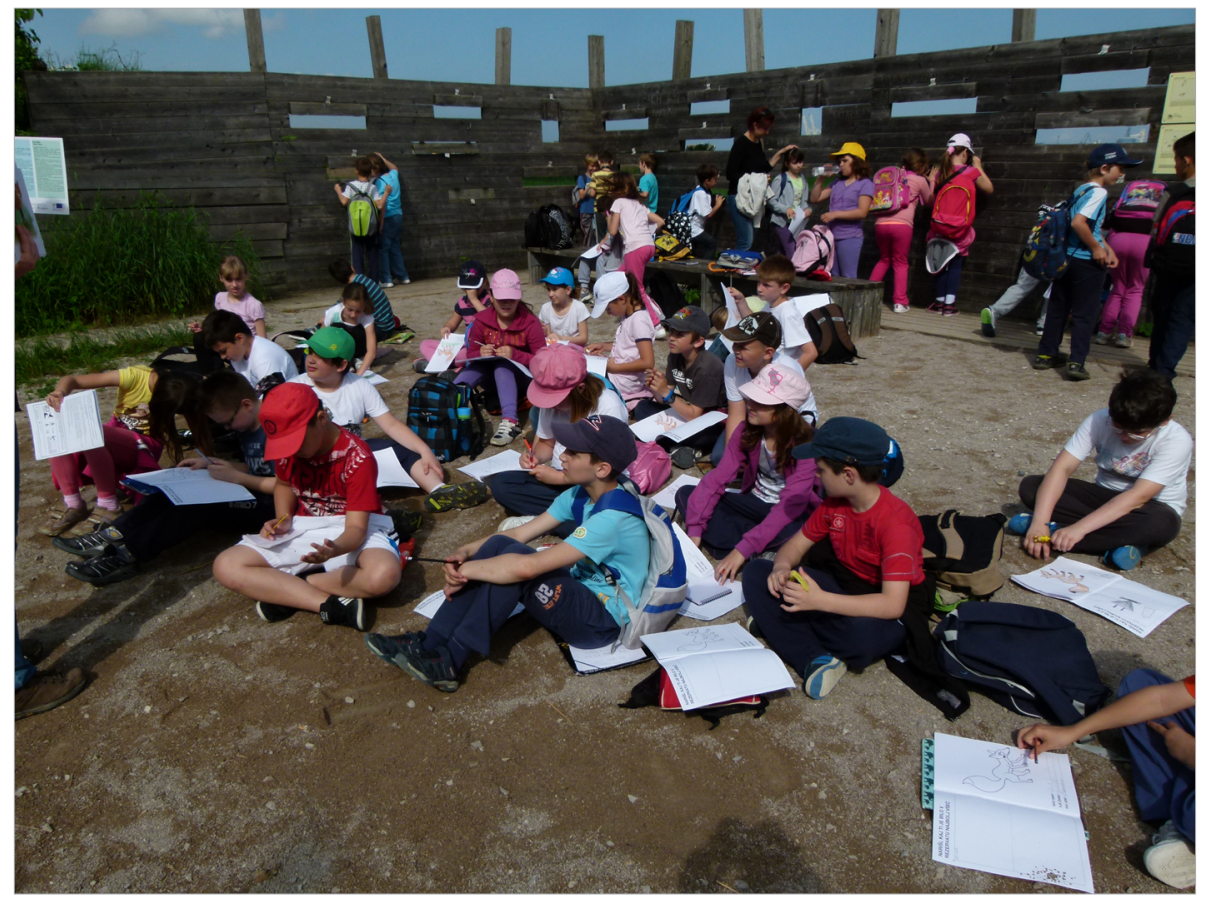

Fig. 3 A group of pupils from primary school during outdoor lessons in Škocjanski zatok

Nature Reserve

Photo by Bojana Lipej, 2013 
observation tower, placed in a strategic location between the lagoon and freshwater wetlands, which offers a great panoramic view of the whole protected area (DOPPS, 2016).

In addition, the visitor centre, which is the main facility of the protected area, is equipped with a modern lecture room and laboratory for practical experiments. At the same time, it provides basic services for visitors who visit the nature reserve (reception with information about the nature reserve, a shop with souvenirs and products from local Slovenian providers, and bar with refreshments). In addition to the basic programmes, visitors can rent a hall at the visitors centre to host their events: mostly conferences and workshops.

The stable with Camargue white horses represents an additional attraction. Riding horses with professional guidance and walking along the nature trail is fun for children. It is necessary to mention that Camargue horses are very important for management of the reserve as they preserve the vegetation balance of the freshwater part of the reserve by grazing. Recently, however, they have become an important part of visitor programmes because visitors like them. Various programmes with horses have been prepared such as "I'm learning and growing with horses", which is based on a holistic approach to the horse world. Children are learning to understand horses as animals and as their friends (DOPPS, 2016).

After the opening of the new visitor facilities in ŠZNR in March 2016, the number of visitors on a yearly basis has ranged from 52,000 to 58,000 (Tab. 1).

Tab. I Number of visitors of Škocjanski zatok Nature Reserve after the opening of new facilities in 2016

\begin{tabular}{lccc}
\multicolumn{1}{c}{ Visitors/Years } & 2016 & 2017 & 2018 \\
\hline Guided visitors (groups) & 7,399 & 7,092 & 7,401 \\
\hline $\begin{array}{l}\text { Visitors related to various } \\
\text { programmes }\end{array}$ & 4,580 & 2,176 & 2,606 \\
\hline All visitors & 51,730 & 58,240 & 54,000
\end{tabular}


The number of visitors who took guided tours has ranged from 4,000 to 7,400 per year. Two peaks are evident throughout the year, the higher spring peak (from 1,400 to approx. 1,800 visitors), and the lower autumn peak (from 900 to approx. 1,300 visitors) (Fig. 4). In winter and in the mid-summer the number of visitors is very low, not exceeding 200 visitors per month. There are no large differences between the compared years.

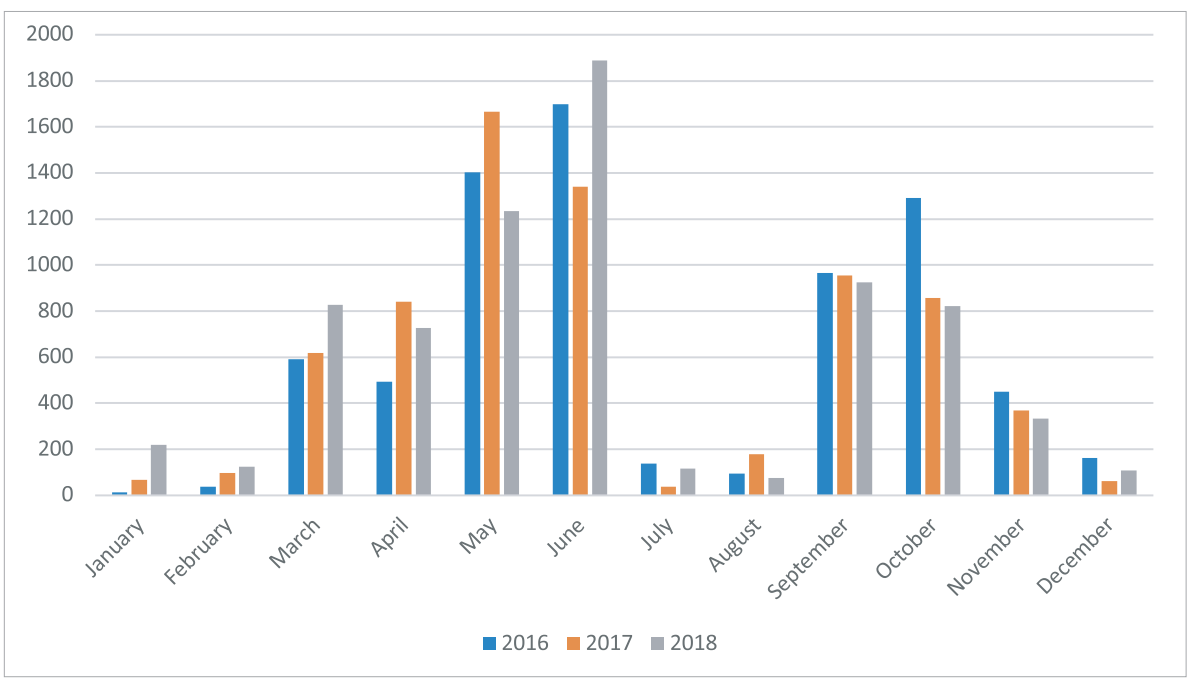

Fig. 4 The number of visitors of Škocjanski zatok Nature Reserve by month in the period of 2016 to 2018

Source: DOPPS, 2019

\section{Škocjanski zatok Nature Reserve as an educational playground}

ŠZNR does not only play an exceptional role as a site for the conservation of rare and endangered species, it also has an important educational role. The diversity of habitats, from freshwater to silt and gravel shores and almost completely marine habitats represent a unique opportunity to carry out various educational activities; mostly outdoor activities which are highly interdisciplinary (integrating science, technical, and social sciences) and incorporate many contemporary didactic approaches that help shape pupils' intellectual abilities, and encourage exploration and scientific thinking. Pupils can learn about nature and its diversity through their own experiences and consequently develop a responsible attitude towards the preservation and protection of the natural environment. 
All of this encouraged the manager of ŠZNR to prepare the first educational programme in $\mathbf{2 0 0 6}$ with the help of an education specialist from the Royal Society for the Protection of Birds (RSPB, UK), and within the framework of the project "AdriaWet 2000 - Adriatic Wetlands for Natura 2000" (OP Slo-Ita 2007-2013). The programme laid the foundations for appropriate educational work with young pupils as well as for raising awareness among the broader public about importance of nature protection. The educational programme was renewed in 2014, based on past educational experiences and exchanging knowledge with educators of similar protected areas in Italy and Slovenia. The main reason for the renovation of the existing educational programme was to spread awareness among young people that nature is vulnerable and sustainable management of natural resources is one of the most important tasks for our future.

The renewed programme created four different educational programmes, oriented toward different age groups:

1. "Nature is a wonderful and magical world", where preschool children discover the secrets of nature through their senses (they learn about diversity in nature with specially prepared children's games);

2. "An adventure trip through Škocjanski zatok Nature Reserve" is a programme for pupils of 6 to 8 years that offers them a playful and instructive way of learning about diversity in nature as well as encouraging their interest in science;

3. "Observing and learning about Škocjanski zatok Nature Reserve" is a programme, prepared for pupils aged 9 to 11 that is based on an active approach. Through experiments, auditory and visual observation, solving puzzles and tasks, young pupils learn about the nature, diversity of habitats, plant and animal species, including how plants and animals adapt to their environments; and

4. "Exploring in Škocjanski zatok Nature Reserve" is a programme prepared for pupils of 12 years and over and is based on active research work. Pupils learn that certain processes and phenomena occur in nature and there are logical explanations for them.

Figure 5 shows the structure of visitors on guided tours (for 2018), which is more or less the same since the opening of the visitor centre in March 2016. The majority of visitors (more than 2/3) are pupils from elementary schools, pupils from secondary schools, and university stu- 


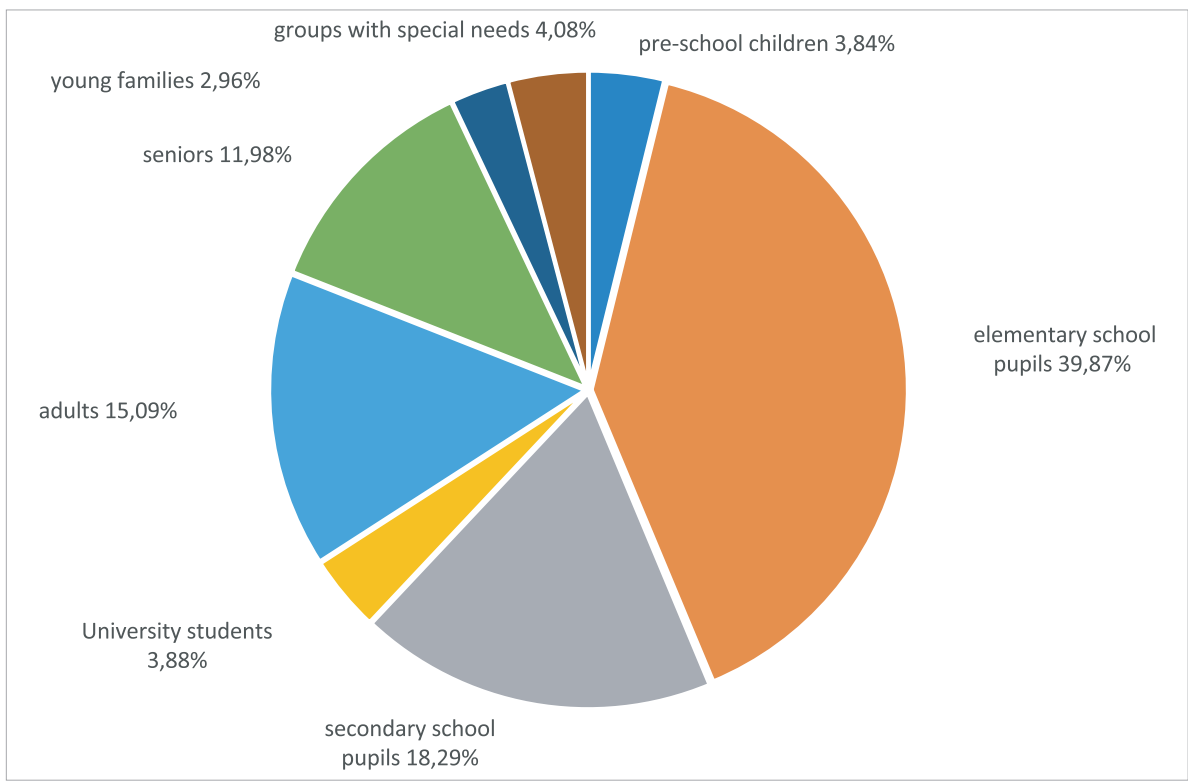

Fig. 5 A structure of the visitors of Škocjanski zatok Nature Reserve in 2018 Source: DOPPS, 2019

dents (more than 200 visit the area every year). Other visitors belong to the groups of adults, seniors and young families, groups with special needs, and preschool children.

It is evident from the above figure that the number of all participants in educational activities (from preschool children to university students), has grown steadily from 2006 to 2018 (Fig. 6). There were about 1,000 in $2008,2,000$ in 2013 , over 4,000 in 2017, and in 2018 there were nearly 5,000.

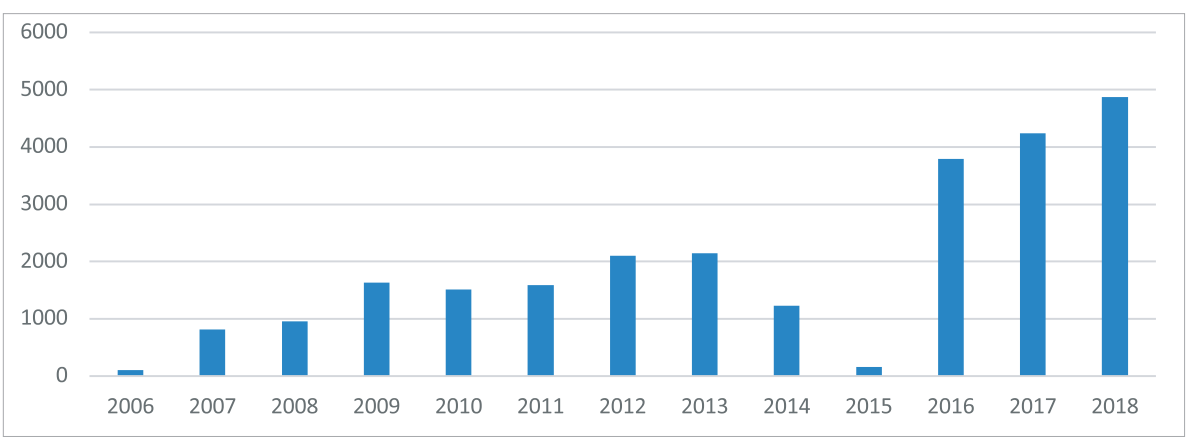

Fig. 6 Number of participants of the educational activities in Škocjanski zatok Nature Reserve in the period of 2006 to 2018 
The only exception was in 2015 when, due to (re)construction of the infrastructure in the reserve, the number of participants in educational activities was negligible.

\section{Škocjanski zatok Nature Reserve and its costs and benefits}

Although the new facilities of ŠZNR opened in 2016, we have already detected some strengths and weaknesses. Among strengths, we should point out the attractions for visitors, with special regard to better quality of life (Fig. 7).

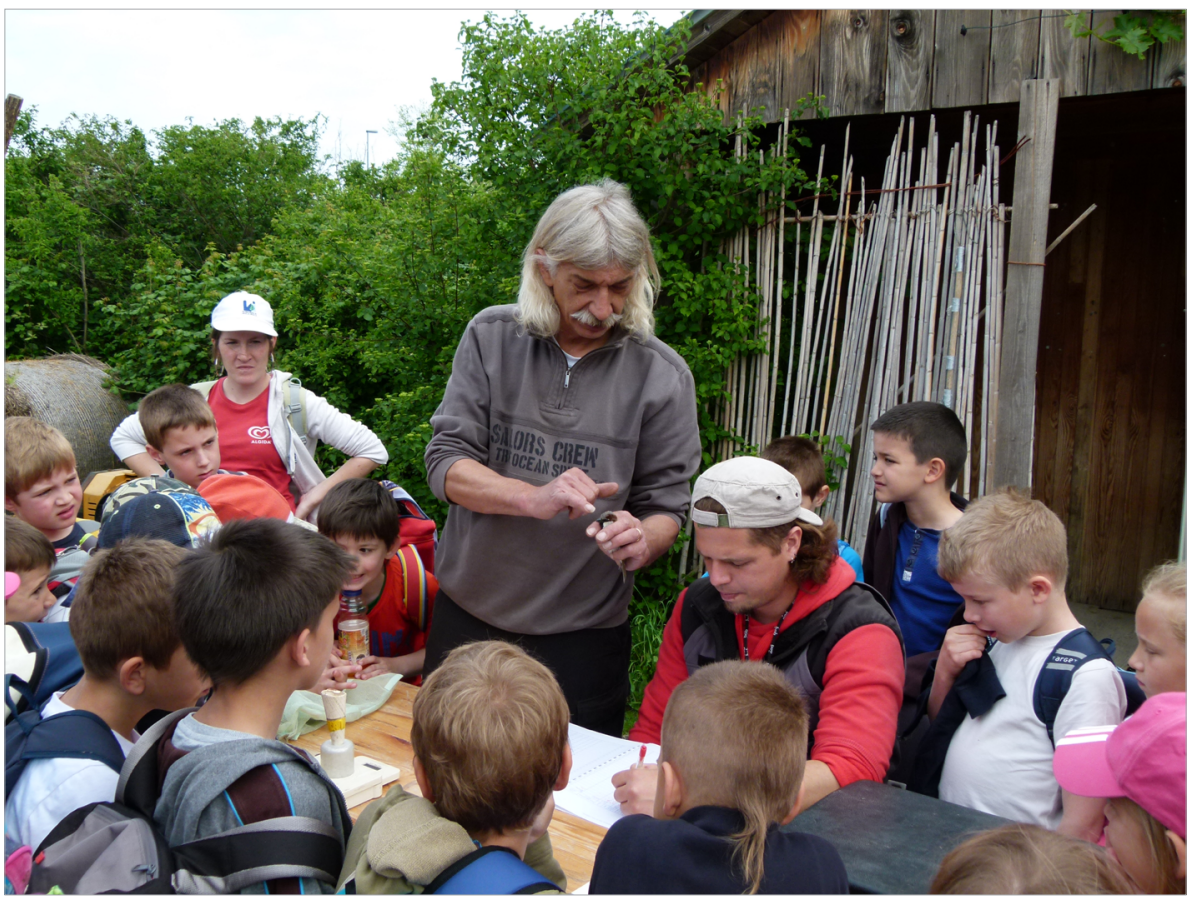

Fig. 7 Lessons for young bird-watchers

Photo by Bojana Lipej, 2014 
Despite its status as a protected area, ŠZNR also acts as a city park for the residents of Koper and an educational playground for young people. Among weaknesses, we should mention the inability to control the number of visitors, which often exceeds optimal capacity. In addition, the lack of skilled personnel is also a disadvantage (Tab. 2).

Tab. 2 Identified strengths and weaknesses of the current state of Škocjanski zatok Nature Reserve after the construction of new facilities

\section{Strengths}

preservation of a protected area in the middle of an urban area contributes to better quality of life for the local people

opportunity to explore, experience and learn in nature (quiet tourism)

the reserve is becoming a new destination of quickly developing nature-based tourism (attracting responsible visitors and helping to extend the region's tourist season)

accessible for people with special needs (disabled, blind, deaf)

situated on the Slovenian coast, it's also an invaluable asset in the promotion of other sights in the area

flexibility in preparation of various programmes and organisation of visits

\section{Weaknesses}

inability to control the number of visitors and no direct contact with the majority of them

too many visitors in relation to optimal capacity

pollution (noise, waste, vandalism, air pollution)

deficiency of the marketing and promotion strategy

visitor programmes are weather dependent

shortage of personnel for carrying out educational activities and working with visitors

possible conflicts of interest with the local community regarding development plans

still not enough contact with local deci-

sion-makers and businesses

Source: DOPPS, 2015

The income derived from visitors represents approximately $10 \%$ of the total ŠZNR management budget. Services (guided tours, workshops, horse riding, hall rentals, lectures, etc.) represent the largest share (almost 50\%) of the total income from visitors. The income from the bar has increased, while the amount of income from purchases in the gift shop has decreased (DOPPS, 2019) (Fig. 8). 


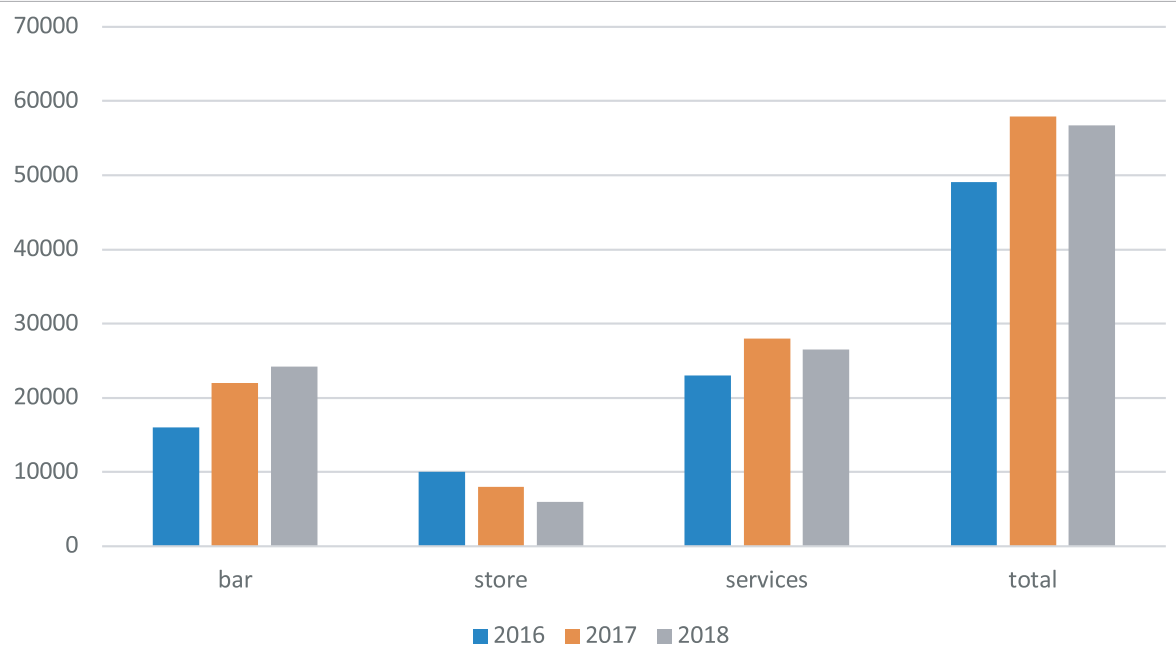

Fig. 8 Income derived from visitors of Škocjanski zatok Nature Reserve in the period of 2016 to 2018

Souce: DOPPS, 2019

\section{Conclusion}

Škocjanski zatok Nature Reserve, once a degraded area, has improved much in terms of biodiversity and now represents a model for successful restoration, due to the successful civil initiative for protected status. Additionally, ŠZNR has regained much of its past biodiversity or even improved from the aspect of certain Natura 2000 habitat types (Ivajnšič and Kaligarič, 2014). Due to its location and infrastructure, ŠZNR also represents an ideal area for the development of environmentally-oriented tourism (Fig. 9). Tourists and visitors in protected areas are mostly oriented toward observing and experiencing nature, and they usually don't make demands on the environment or harm the local flora and fauna (Lipej and Kerma, 2017).

The number of visitors after 2016 shows that Škocjanski zatok has already become a tourist attraction for all kinds of visitors, not just researchers and locals. In order to preserve the exceptional nature and biodiversity of the reserve appropriate promotion and marketing strategy as well as visitor programmes that will ensure sustainability of the area and successful development of different forms of sustainable and responsible tourism should be arranged. The nature reserve and its countryside offer great possibilities for development of nature-based tourism in general. Outdoor ac- 


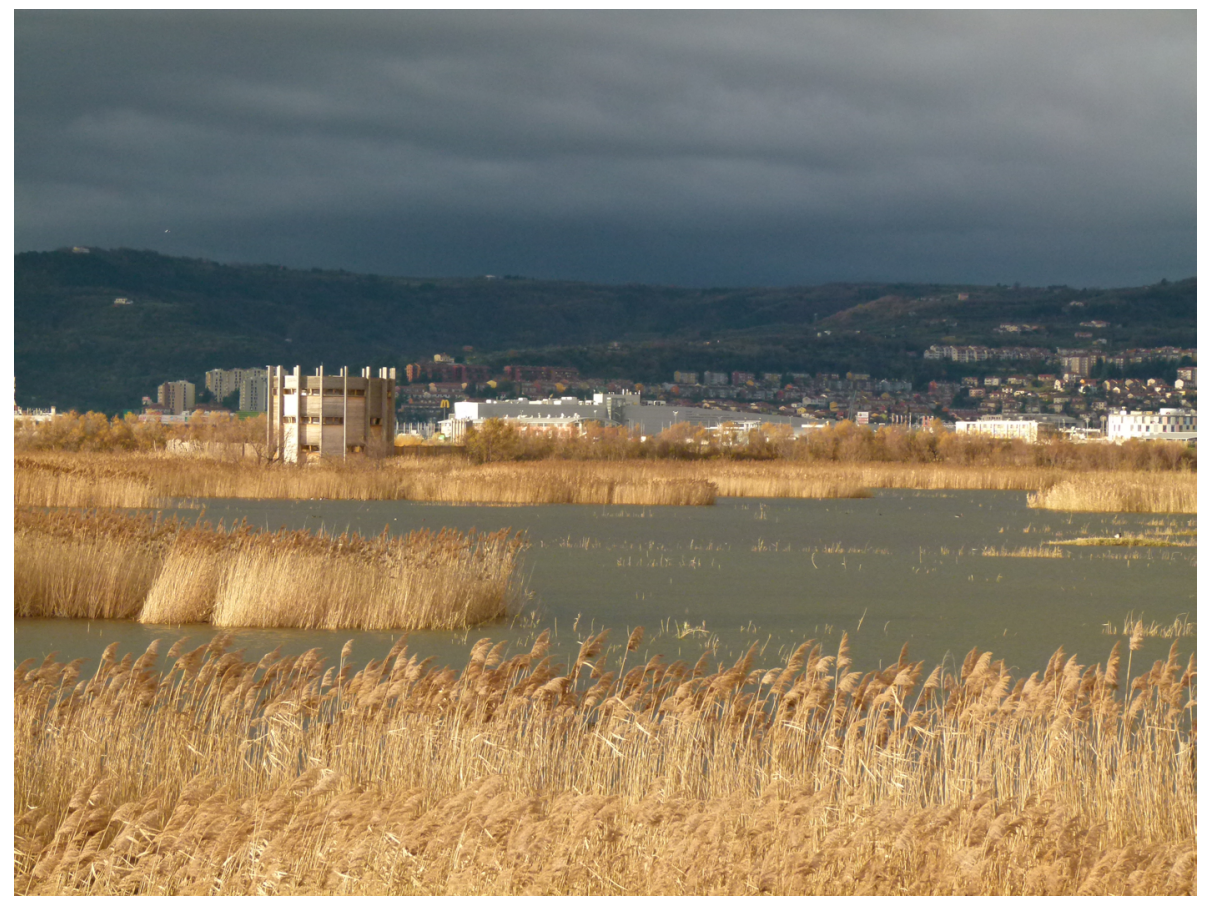

Fig. 9 Panoramic view over the freshwater part of Škocjanski zatok Nature Reserve Photo by Bojana Lipej, 2017

tivities, observation of nature, education in a natural local environment can be linked to learning about quality local gastronomy and staying in an authentic local environment, which is a win-win situation for the locals as well as the visitors (Jurinčič et al. 2011, 150).

Tourism activities that are small-scale, implemented quietly, and do not cause pollution, disturb nature, or require additional actions, are compatible with the basic goals of nature conservation. These are the key differences that separate tourism activities inside and outside protected areas (Sovinc, 2017). Since the beginning of the reserve's restoration, a total of $€_{3.1}$ million has been spent for that purpose. This is another one of many examples of how it is better to conserve (or maintain) rather than restore. One of the main challenges for the future of Škocjanski zatok Nature Reserve is to obtain equilibrium between nature conservation and sustainable tourism. 


\section{References}

Balažič, G., Jurinčič, I., Sinkovič, L. 2011: Naravni rezervat Škocjanski zatok kot del integralnega turističnega proizvoda, in: Razvoj zavarovanih območij $v$ Sloveniji (eds. Nared, J. et al.), Knjižna zbirka Regionalni razvoj, Založba ZRC, Ljubljana, 53-61.

Brečko Grubar, V., Kovačič, G., 2011: Odnos prebivalcev Mestne občine Koper do Škocjanskega zatoka, in: Razvoj zavarovanih območij v Sloveniji (eds. Nared, J. et al.), Knjižna zbirka Regionalni razvoj, Založba ZRC, Ljubljana, 63-70.

Chan, K. M. A., Shaw, M. R., Cameron, D. R., Underwood, E. C., Daily, G. C., 2006: Conservation Planning for Ecosystem Services, PLOS Biology 11, DOI: 10.1371/journal.pbio.0040379.

Figueroa, B. E., Aronson, J., 2006: New linkages for protected areas: Making them worth conserving and restoring, Journal for Nature Conservation 14 (3-4), 225-232, DOI: 10.1016/j.jnc.2006.04.007.

Guillemain, M., Blanc, R., Lucas, C., Lepley, M., 2007: Ecotourism disturbance to wildfowl in protected areas: historical, empirical and experimental approaches in the Camargue, Southern France, Biodiversity and Conservation 16 (12), 3633-3651, DOI: 10.1007/s10531-007-916o-Z.

Ivajnšič, D., Kaligarič, M., 2014: How to Preserve Coastal Wetlands, Threatened by Climate Change-Driven Rises in Sea Level, Environmental Management 54 (4), DOI 10.1007/soo267-014-0244-8.

Jurinčič, I., Balažič, G., Sinkovič, L., 2011: Škocjanski zatok nature reserve as opportunity for development of ecological tourism, in: Sustainable tourism: socio-cultural, environmental and economic impacts (ed. Perić, J.), International Scientific Conference Tourism in South East Europe, University of Rijeka, Faculty of Tourism and Hospitality Management, Rijeka, Opatija, 147-158.

Jurinčič, I., Popič, A., 2009: Sustainable Tourism Development in Protected Areas on the Pattern of Strunjan Landscape Park, Varstvo Narave 22, 177-192.

Kaligarič, M., Ivajnšič, D., 2014: Habitat Changes Caused by Sea Level Rise, Driven by Climate Change in the Northern Adriatic Coastal Wetlands, Slovenia, in: Managing Protected Areas in Central and Eastern Europe Under Climate Change (eds. Rannow, S., Neubert, M), Advances in Global Change Research 58, Springer, Dordrecht, DOI 10.1007/978-94-007-7960-0_15. 
Kaligarič, M., Makovec T., Mozetič, B., 1993: Ohranitev in renaturacija Škocjanskega zatoka, Informativna zgibanka, DOPPS and Slovenski sklad za naravo, Ljubljana.

Lipej, L., Kerma, S., 2017: Marine and coastal biodiversity and tourism in the Slovenian part of the Adriatic Sea: A neglected story?, in: Tourism of protected areas of nature in Serbia and Slovenia (eds. Filipović, D. et al.), University of Belgrade, Faculty of Geography, Belgrade, 101-112.

Lipej, L., Mavrič, B., Orlando-Bonaca, M., Malej, A., 2012: State of the Art of the Marine Non-Indigenous Flora and Fauna in Slovenia, Mediterranean Marine Science 13 (2), 243-249, DOI: 10.12681/mms.304.

Mozetič, B., Lipej, B. (eds.), 2014: Zeleno srce Kopra - vodnik po Naravnem rezervatu Škocjanski zatok, $2^{\text {nd }}$ edition, DOPPS, Ljubljana.

Mozetič, B., Lipej B., Šalaja N. (eds.), 2010. Zeleno srce Kopra - vodnik po Naravnem rezervatu Škocjanski zatok, DOPPS, Ljubljana.

Mozetič, B., Šalaja, N., 2005: Naravni rezervat Škocjanski zatok-območje naravnih vrednot $v$ evropski mreži območij Natura 20oo, Internal source.

Nikodinoska, N., Paletto, A., Franzese, P.P., Jonasson, C., 2015: Valuation of Ecosystem Services in Protected Areas: The Case of the Abisko National Park (Sweden), Journal of Environmental Accounting and Management 3 (4), 355-369, DOI: 10.5890/JEAM.2015.11.005.

Ogrin, D., 1995: Podnebje Slovenske Istre, Knjižnica Annales, 11, Zgodovinsko društvo za južno Primorsko, Koper.

Pitacco, V., Lipej, L., Mavrič, B., Mistri, M., Munari, C., 2017: Comparison of benthic indices for the evaluation of ecological status of three Slovenian transitional water bodies (northern Adriatic), Marine Pollution Bulletin 129 (2), 813-821, DOI: 10.1016/j.marpolbul.2017.10.085.

Pueyo-Ros, J., 2018: The Role of Tourism in the Ecosystem Services Framework, Land 7 (3), 1-13, DOI: 10.3390/land7030111.

Reyers, B., Polasky, S., Tallis, H., Mooney, H. A., Larigauderie, A., 2012: Finding common ground for biodiversity and ecosystem services, BioScience 62 (5), 503-507, DOI: 10.1525/bio.2012.62.5.12.

Sovinc, A., 2012: Assessment of the use values of the Sečovlje Salina Nature Park (Slovenia), Annales: anali za istrske in mediteranske študije - Series Historia Naturalis 22 (2), 189-196.

Sovinc, A., 2017: Explanatory notes on international standards for planning tourism and use of natural resources in some categories of protected areas, in: Tourism of protected areas of nature in Serbia and Slovenia 
(eds. Filipović, D. et al.), University of Belgrade, Faculty of Geography, Belgrade.

Šalaja, N., 2016: Programi obiskovanja Naravnega rezervata Škocjanski zatok s ciljem spodbujanja odgovornega vedenja do narave, Master Thesis, University of Ljubljana, Biotechnical Faculty, Ljubljana.

Šalaja, N., Mozetič, B., Kaligarič, M., Marčeta, B., Lipej, L., Lipej, B., Brajnik, I., 2007: Oaza na pragu Kopra. Obnova in ohranjanje habitatov in ptic $v$ Naravnem rezervatu Škocjanski zatok, LIFEOONAT/SLO/7226, DOPPS, Ljubljana.

Škornik, I., Makovec, T., Lipej, L., 1995: Sečovlje Salina - An ornithological assessment of a Slovene coastal wetland, Annales: anali za istrske in mediteranske študije - Series Historia Naturalis 7, 89-94.

Učakar T. 2009.: Geografija naravnega rezervata Škocjanski zatok, Gradution Thesis, University of Ljubljana, Faculty of Arts, Ljubljana.

\section{Sources}

DOPPS - Društvo za opazovanje in proučevanje ptic Slovenije, 2007: Poročilo $v$ okviru projekta „Obnova in ohranjanje habitatov in ptic $v$ naravnem rezervatu Škocjanski zatok“, LIFEooNAT/SLO/7226, Ljubljana.

DOPPS - Društvo za opazovanje in proučevanje ptic Slovenije, 2015: Management plan of Škocjanski zatok Nature Reserve for the period 20152024, Ljubljana.

DOPPS - Društvo za opazovanje in proučevanje ptic Slovenije, 2016: Visitation conditions, http://www.skocjanski-zatok.org/en/visit-us/visitation-conditions (10. 10. 2019)

DOPPS - Društvo za opazovanje in proučevanje ptic Slovenije, 2019: Management of Škocjanski zatok Nature Reserve in the period from 2009 to 2018 - Report of Public Service.

Surveying and Mapping Authority of the Republic of Slovenia (special aerial filming for years 1954 and 1969; cyclical aerial filming for years 1975, 1985, 1988, 1992, 2006 and 2014).

Škocjanski zatok Nature Reserve Act, 1998: Uradni list RS 20/98. 



\section{Chapter 9}

Spatial planning of tourism in protected nature areas in Slovenia and the tourism carrying capacity of Škocjan Caves Regional Park

Igor Jurinčič

\section{Abstract}

In this chapter, we assess the importance of spatial planning for the successful implementation of sustainable tourism in protected nature areas. We have found that joint development of planning and comprehensive cooperation between protected area management and the local community is crucial. This is shown by analysis of the preparation of adopted spatial acts for certain protected areas in Slovenia. Since these are mainly areas that extend into the territory of several neighbouring municipalities, it is clear that such protected nature areas should be regulated by regional spatial plans.

Key words: spatial planning, protected areas, regional spatial plan, environmental impact assessment, carrying capacity, Slovenia

\section{Introduction}

Following the prevailing processes of industrialisation and urbanisation that ran through the end of 1980s, the rise of the importance of biodiversity and the implementation of the sustainable development paradigm took place in Slovenia in the 1990s. The global proclivity for draining land to encourage intensive agricultural exploitation and urbanisation was partially replaced by the process of renaturation and protection of areas of (relative- 
ly) unspoiled nature, especially wetlands, for purposes of conservation of biodiversity, under the influence of Agenda 21 and the Ramsar Convention. This procedural change was followed by spatial planning, periodical evaluations of spaces in accordance with changes in the economic situation, and the coordination of various interests in the region (Jurinčič, 2011).

Regional development and spatial planning in the European Union is based on regional policies and pre-defined developmental priorities and financial perspectives-at the regional level these are realised via regional development programmes (RDP). For such pre-defined development projects that are in accordance with the Spatial Planning Act (2007), state, regional, and local governmental bodies prepare spatial plans in order to enact appropriate spatial interventions.

Spatial planning in protected areas is a good tool for management organisations and is the result of cooperation with the local community and other stakeholders in protected areas and their surroundings. Park management authorities can implement a sustainable tourism strategy, conceive and carry it out in their plans, and define protection and development aims within the spatial planning process.

\section{Spatial planning at the national, regional, and local levels}

At present, $13.3 \%$ of total Slovenian territory is protected (as areas of nature), out of which Triglav National Park represents $4.1 \%$ of the total territory of Slovenia (Slovenian Environment Agency, 2019b). Thereby, 3 regional parks, 46 landscape parks, 1 strict natural reserve, 56 natural reserves, and 1,164 natural monuments are protected. With the implementation of the Spatial Development Strategy of Slovenia (Bartol, 2004) in July 2004, it was estimated that protected nature areas would come to cover $33 \%$ of Slovenia's territory in the future. To a large extent, the development of sustainable and eco-tourism in protected natural areas is the recommended practice. However, there are some shortcomings in the implementation of such plans: the shortage of qualified labour; lack of financing and appropriate expertise; lack of interest in municipalities; and lack of political support-not to mention problems stemming from the reorganisation of states at the local governance level, and almost non-existent inter-sectoral mutual interest and cooperation (Jurinčič and Bojnec, 2009).

In April 2004, Slovenia endorsed and confirmed the proposal establishing Natura 2000 areas. Slovenia has been identified as having the highest level of biological diversity in the EU. Two hundred and eighty-six are- 
as have been identified, out of which 260 have been identified on the basis of regulation of habitats (32\% of Slovenian territory) and 26 on the basis of regulation of birds (23\% of Slovenian territory) (Fig. 1). Often, there is an

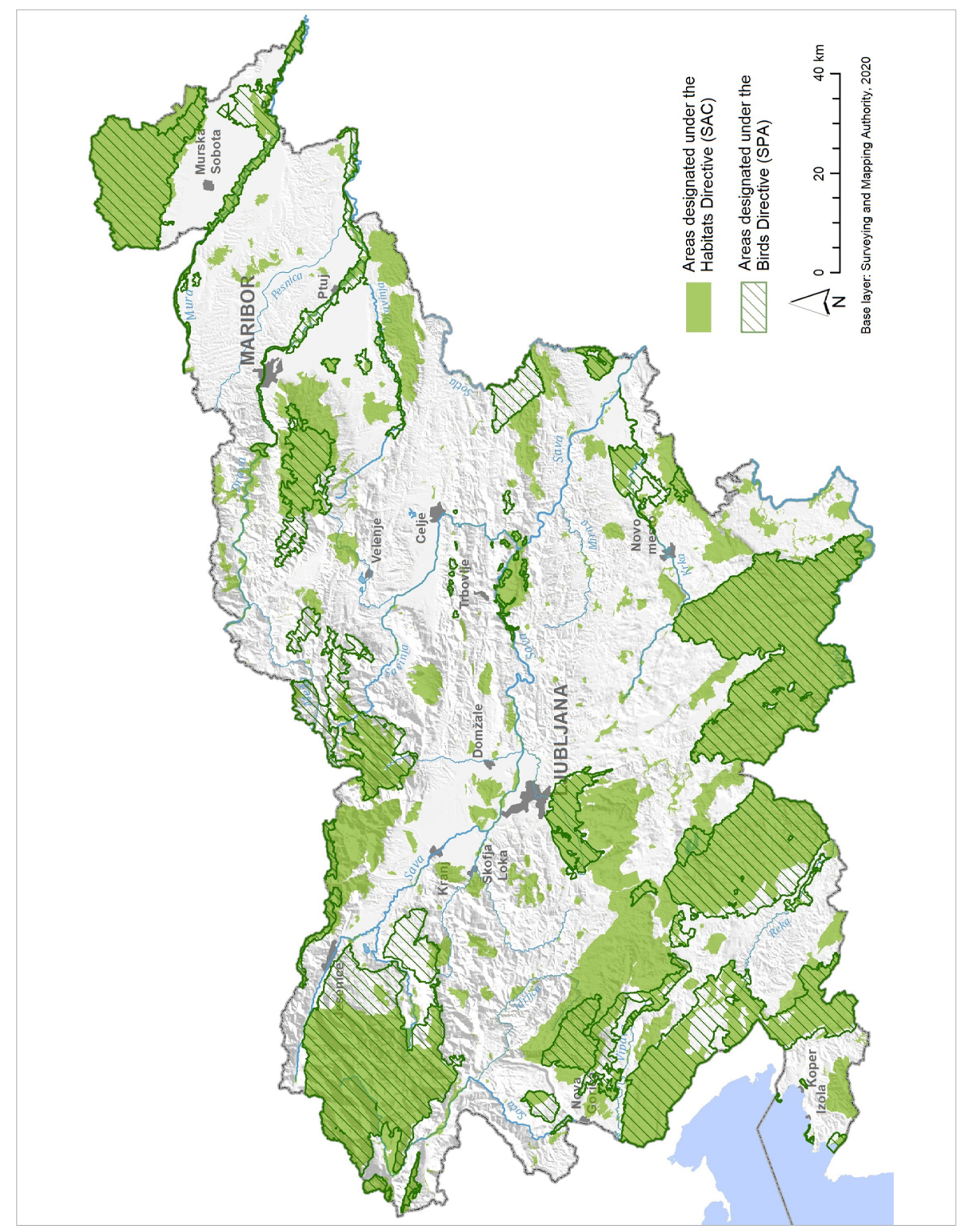

Fig. I Natura 2000 areas in Slovenia

Source: Slovenian Environment Agency, 2019a 
overlap of these geographical areas, because $60 \%$ of the areas proposed on the basis of regulation of habitats are also included within the proposed special protected areas for regulation of birds. Both types of Natura 2000 areas (habitats and birds) together cover $36 \%$ of Slovenian territory in total.

Most of the protected areas are covered by forests $(70,6 \%)$, which is the prevailing landscape in Slovenia. A significant proportion of its protected areas are rocky land areas without vegetation, $9 \%$ of protected areas are situated above the tree line, and a significant proportion is covered by grassland. Twenty-five percent of Slovenia's territory is located within the boundaries of its protected areas (Triglav National Park, regional and landscape parks, as well as in reserve and natural monuments), which are also Natura 2000 areas.

The preservation of nature, particularly of biodiversity, is not the task of the natural resources protection sector alone, which does not have sufficient staff and resources for this purpose. Therefore, the natural resources protection sector needs to be developed further and particularly strengthened with partnerships and cooperation with other participating sectors, such as forestry, agriculture, tourism, and similar activities, which operate within most natural attractions. More resources to support biotical diversity, provide advice, and monitor the implementation of nature protection or conservation programmes should also be reoriented toward these goals.

At the time of writing, the Slovenian state has not yet set up a system to provide protected nature areas with the implementation of a scheme that would insure a comparative advantage to make up for the constraints in economic development that are caused by nature protection imperatives. Regardless of the fact that protected nature areas provide general environmental benefits, they also have an important economic role. The current situation of management of protected nature areas is associated with generally-accepted normative protection, which is based on a system of laws and restrictions that do not provide enough attention, resources, and expert support in practice.

On the other hand, Slovenia has had some positive experiences in the implementation and monitoring of protected nature areas, such as in Triglav National Park, Škocjan Caves Regional Park, Notranjska, and Kozjansko, nature parks in Logar Valley, Goričko, the Ljubljana Marsh, the Kolpa River, Sečovlje and Strunjan Saltpans, and Škocjanski zatok Nature Reserve. All these protected areas have a management organisa- 
tion which is responsible for the protection of nature and the development of environmentally-friendly activities. Comparative advantages based on providing environmental goods have been identified as particularly important in tourism development. This is, however, not well known, visible or well presented to the broader society, local communities, and local economies, which are situated in territories envisaged for protected areas in Slovenia.

Therefore, it is advisable to organise visits for the local population to see "examples of good practice" in these matters, so that stakeholdersfrom residents to business people-could learn about successful examples of developing activities related to the maintenance of nature parks and means of cooperation between the management of parks and the local population (Jurinčič and Bojnec, 2007). Management organisations of nature parks provide local communities with advisory support to develop and implement their own ideas, initiatives, and innovations, as well as support for project development and business plans-in order for them to be more successful in gaining financial support from domestic and international sources.

Local communities must be aware of the exceptional development potential of organic farming and ecological tourism in protected nature areas (Cigale et al., 2010; Podmenik et al., 2012; Potočnik Slavič et al., 2016). The opinion of local people is crucial in the process of spatial planning as they are invited to participate in the public hearings of all proposed spatial plans. It is therefore important that local population be included in the preparation of management plans for nearby protected areas.

The Spatial Planning Act (2007) provides for spatial interventions spanning the territory of two or more municipalities and the elaboration of an inter-municipal plan, or regional spatial plan. Regional spatial plans also provide for the regulation of infrastructure projects that are planned in regional development programmes (RDP). Because cooperation between municipalities has not yet been formally solidified, municipal councils must adopt decrees regarding regional spatial plans, with an appropriate text and cartographic attachments. Thereby, interventions in areas that cover the territory of several municipalities and infrastructure of national importance shall be governed by national spatial plans (NSP), and accepted and confirmed by the national government.

For spatial interventions in the neighbouring zones of protected areas to meet the needs of sports and recreation they must consider the NSPs or 
spatial plans (lokacijski načrt or LN) and a regulatory plan (ureditveni načrt or UN) prior to the enactment of the Spatial Planning Act in 2007; for some examples: Šmartinsko Lake, the Lipica Stud Farm (phase 1) and Škocjanski zatok Nature Reserve. Work is in progress for NSP Lipica Stud Farm (phase 2) and the area of Celje Hut (Insight into the procedures for the preparation of state spatial planning acts, 2019).

Within the spatial plan for Škocjanski zatok Nature Reserve (Ordinance on the regulatory plan for the area of the Škocjanski zatok Nature Reserve, 2002), plans were made for restorations, observatories, a visitor centre, and trails (Vidmar, 2004). More than $2 \mathrm{~km}$ of circular trail was constructed, laid out along the border of the freshwater part of the reserve. The trail starts from the visitor centre, which is located in the easternmost part of the reserve. The visitor centre was opened in March 2016 (Fig. 2) and ponds of various shapes and sizes were created along its length, which were quickly settled by invertebrates and amphibians. Furthermore, these ponds serve as models that help visitors get a closer look at the life in the marsh. The material excavated during the creation of the freshwater marsh was used to construct screening embankments along the newly-formed circular trail,

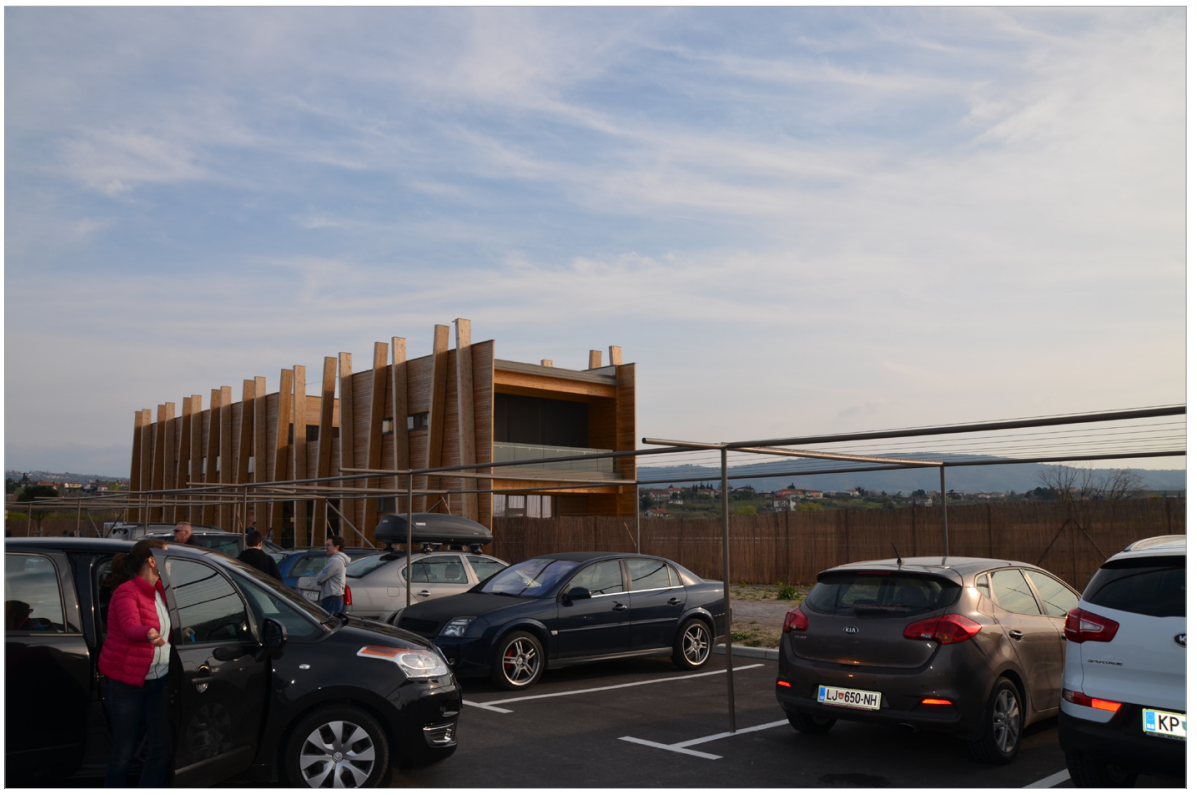

Fig. 2 The visitor centre in Škocjanski zatok Nature Reserve Photo by Igor Jurinčič, 2016 
in order to prevent disturbance of wildlife on the part of visitors. Currently there are six full-time wardens employed at the reserve, which was enabled using EU funding.

The spatial plan was the appropriate legal basis for management to obtain all required permissions and building permits for the reserve's restoration and construction of visitor facilities (trails, visitor centre, observation posts); this was implemented and financed through public funds (EU, state, municipality) and the European projects "Life", "Life +", "Interreg Slovenia - Italy", as well as the European Regional Development Fund (ERDF). Some projects were also financially supported by the Port of Koper. Spatial and environmental planning has to be strictly in line with nature protection measures that are conditional on successful development, in the sense of ecologically-oriented tourism activities as parts of an integral tourist product (Balažič et al., 2011).

\section{Environmental impact assessment}

During the procedure of issuing a building permit for spatial interventions it is necessary to elaborate an environmental impact assessment (EIA), and an environmental report or a comprehensive environmental impact assessment is required for any spatial intervention in a protected area. The result of the environmental report usually authorises an intervention in the space with minor corrections to the project; for example, the extension of the golf course in Lipica (Smrekar and Kolar Planinšič, 2009).

Planned spatial interventions are very rarely rejected because of unacceptable impacts on the environment. One such case was the plan to establish 33 wind power generators on Volovja reber below Snežnik Mountain (in a Natura 2000 area), which was rejected because of its potential negative impact on birds. This led interested parties to find more suitable locations for wind power stations in Slovenia, taking into account a conservationist point of view at an early stage of spatial planning.

Strategic environmental assessments (SEA) or comprehensive environmental impact assessments are an important European environmental policy tool. It is based on transposition and implementation of the Strategic Environmental Assessment Directive (Directive 2001/42/EC) for plans and programmes. Strategic environmental assessments have been performed for the current Regional Development Operational Programme and other plans in Slovenia. In the case of spatial planning for Lipica, an SEA and environmental report with appropriate assessments according to the Habitats 
Directive was carried out. Recommendations were made to investors to slightly modify the planned distribution of golf holes on the golf course, in order to avoid the protected Natura 2000 area. This can be seen in Fig. 3.

\section{Carrying capacity analysis}

The World Tourism Organisation (UNWTO) and the United Nations Environment Programme (UNEP) recommend that, apart from holistic physical planning, efficient tourist destination management should include a carrying capacity analysis for individual tourist destinations and areas (Guidelines for Carrying Capacity Assessment for Tourism in Mediterranean Coastal Areas, 1996). Planned and possible improvements in different development programmes and strategies, suggested by local residents and tourists, should also be taken into consideration (Jurinčič et al., 2007).

Current practice confirms that the analysis of carrying capacity is an essential process in spatial planning that is intended for examination of an area in the preparation process of municipal development strategies of tourism. Škocjan Caves Regional Park was the first tourist attraction in Slovenia on the global list of natural and cultural heritage of UNESCO and certainly deserves special attention. We are going to determine the carrying capacity of the cave, i.e. the maximum number of visitors allowed to be in the cave at a given time. Based on this analysis, we are also going to propose some measures that could be taken in order to monitor and increase the calculated carrying capacity for tourism, which would enable the implementation of a sustainable tourism development scenario in Škocjan Caves Regional Park.

The Fig. 4 shows all visitors between 1999 and 2019. It is evident that the number of visitors has been growing over the last 20 years. Since 2011, there has been a tour of an additional part of Škocjan Caves-Mahorčič and Marinič caves near Škocjan, where the Reka River goes underground. In this new part of the park, an individual tour following the Reka River's journey underground is available in the summer. The park's staff and guides are located at key points throughout the cave system, and visitors can explore without expressed guidance. In the spring and in October, a guided tour is organised in this part of the cave system. In the winter, this part of the cave is closed, because the trail runs next to the river and, in the colder months, is often flooded. 


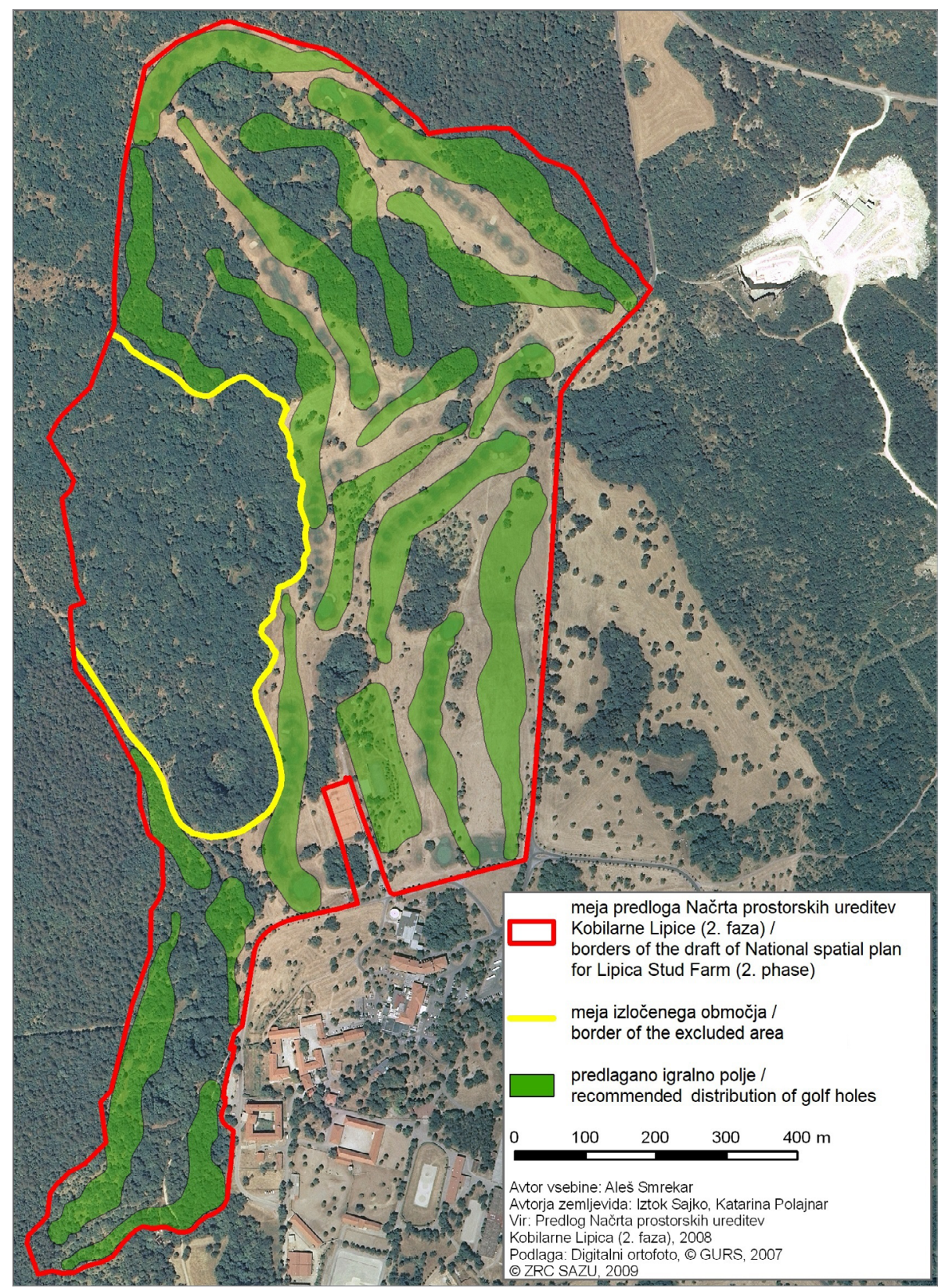

Fig. 3 Proposal for the distribution of golf holes after the inclusion of an environmental perspective

Source: Smrekar and Kolar Planinšič, 2009 


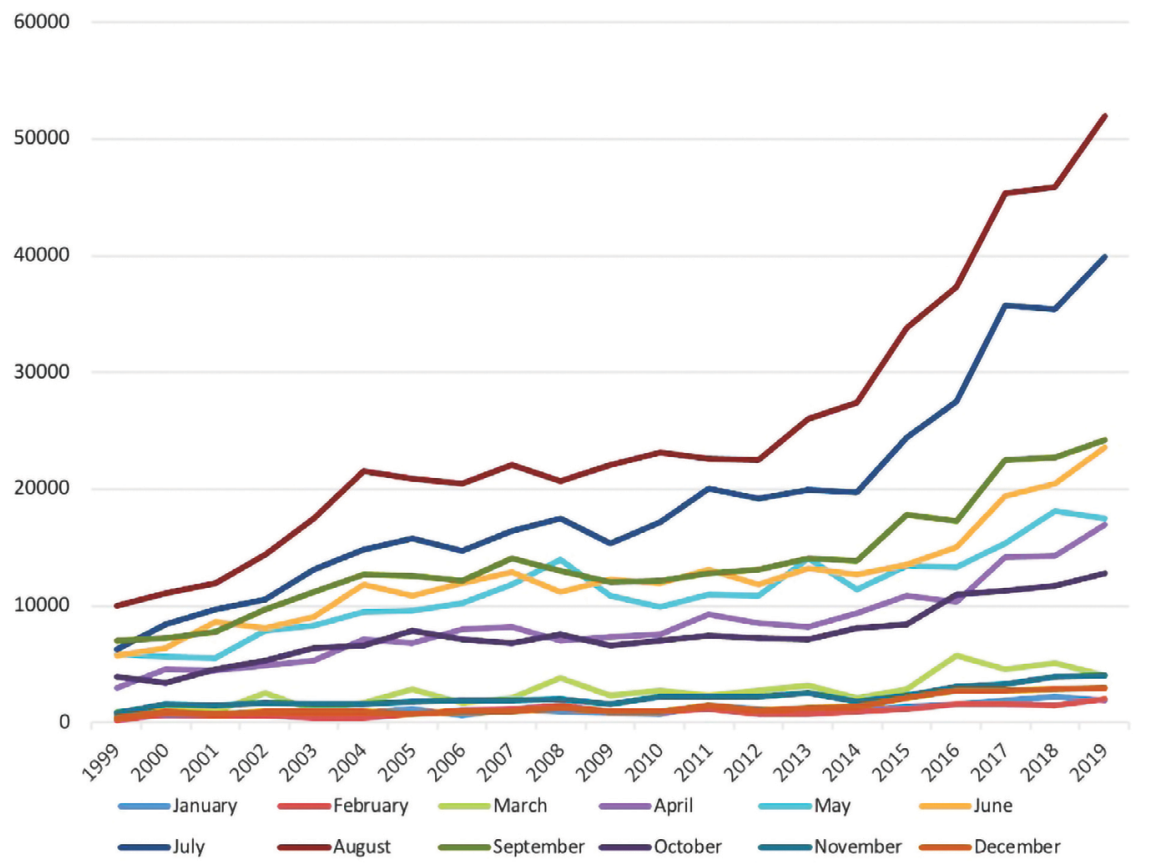

Fig. 4 Number of visitors per year and month in the 1999-2019 period Source: Škocjan Caves Public Service Agency, 2019

The number of cave guides increased accordingly with the increased number of visitors (Fig. 5), which was established in a 2010 visit analysis (Jurinčič and Balažič, 2011).

It needs to be emphasised that the carrying capacity of Škocjan Caves is directly related to the number of available guides. They can offer a quality interpretation and, at the same time, ensure the appropriate behaviour of visitors in a highly sensitive natural environment, but only when there is a manageable number of visitors in a given group. Therefore, the park management has put a lot of effort in recent years into find suitable staff and also train them to be licenced cave guides. The number of visitors is restricted by park management according to the number of guides available. A maximum of 50 visitors is the limit per guide for guided tours of the cave, and 25 visitors per guide for tours around the park.

The park management has also been investing a lot of effort into extending the tourist season, including through pricing of tickets. This is evident from figures 4 and 5 . They have structured three different price brackets for the best-selling "Through the underground canyon" tour of Škocjan 


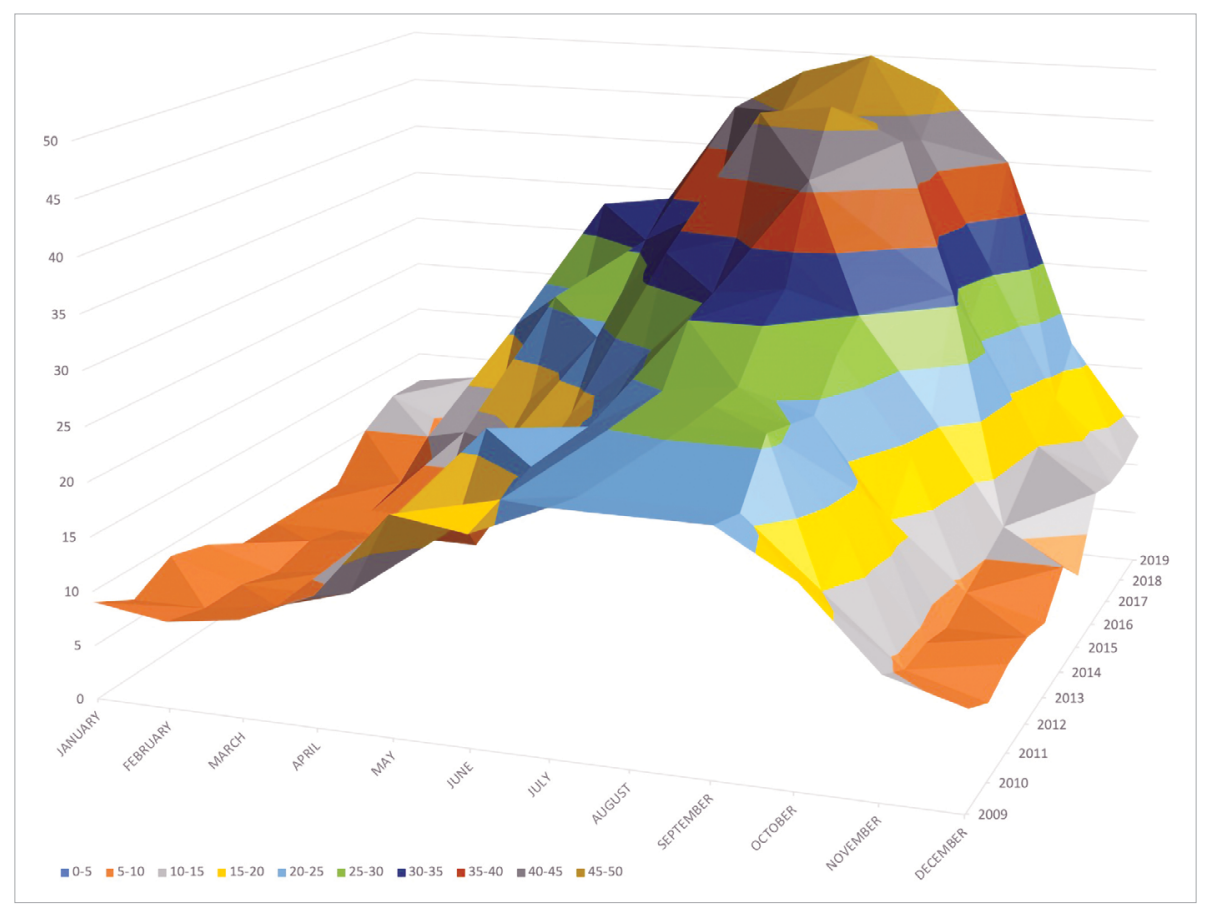

Fig. 5 Number of tourist guides per month in the 2009-2019 period Source: Škocjan Caves Public Service Agency, 2019

Caves. During the winter months, ticket costs $€ 16.00$, in the spring and autumn $€ 18.00$, and in the summer months $€ 20.00$ (the prices are based on the year 2019). They also have some special offers and discounts during the off-season, when organised groups (e.g. school groups and various interest groups) are invited. This means that the seasonal employment of cave guides was extended from the original four months to seven months (Fig. 5). As of 2019, online ticket sales are available for cave tours.

A new museum collection "History of Discovering Škocjan Caves" was opened in the park in 2015. Since 2016, a virtual tour of Škocjan Caves with VR glasses is available for people who are (for whatever reason) unable to enter the cave but want to take the tour. In addition to tours of Škocjan Caves, various events, congresses and seminars are also held in the Park. Tours are offered for both tourists and experts (for example with Škocjan Learning Trail, established in 2003) and museum collections (ethnological, archaeological, geological, and cave history) have been arranged in some formerly-abandoned and decaying structures of the settlements Betanja, Škocjan, and Matavun. 
A new car park was constructed in 2017 in the central part of the park's reception centre, where the information point is located, in accordance with all nature protection standards. Felt was placed on the ground to prevent water from entering the underground waterways and covered with asphalt in the middle of the parking areas; grease and oil traps were also installed, through which the storm water drains into the storm sewer. Additional parking was arranged at the exit from the highway at Divača in the Risnik Business Zone, taking into account the guidelines regarding reducing the amount of traffic in protected areas and not increasing the size and amount of parking lots. From there, a free shuttle service to the park's reception centre is organised for visitors during the summer months. The park has also organised a year-round free shuttle bus service for visitors arriving in Divača by train or bus, in cooperation with Slovenian Railways.

In 2018, Škocjan Caves were visited by 184,230 visitors $(22,166$ domestic and 162,064 foreign guests). By country of origin (for some guests, country of origin is unknown), the largest group of foreign guests were British $(32,018)$, followed by Italians $(18,380)$, Germans $(17,264)$, then guests from Czechia, France, Spain, USA, Netherlands, Poland, and Hungary (Fig. 6). It is evident that the structure of visitors by country of origin did not change significantly from 2018 to 2019.

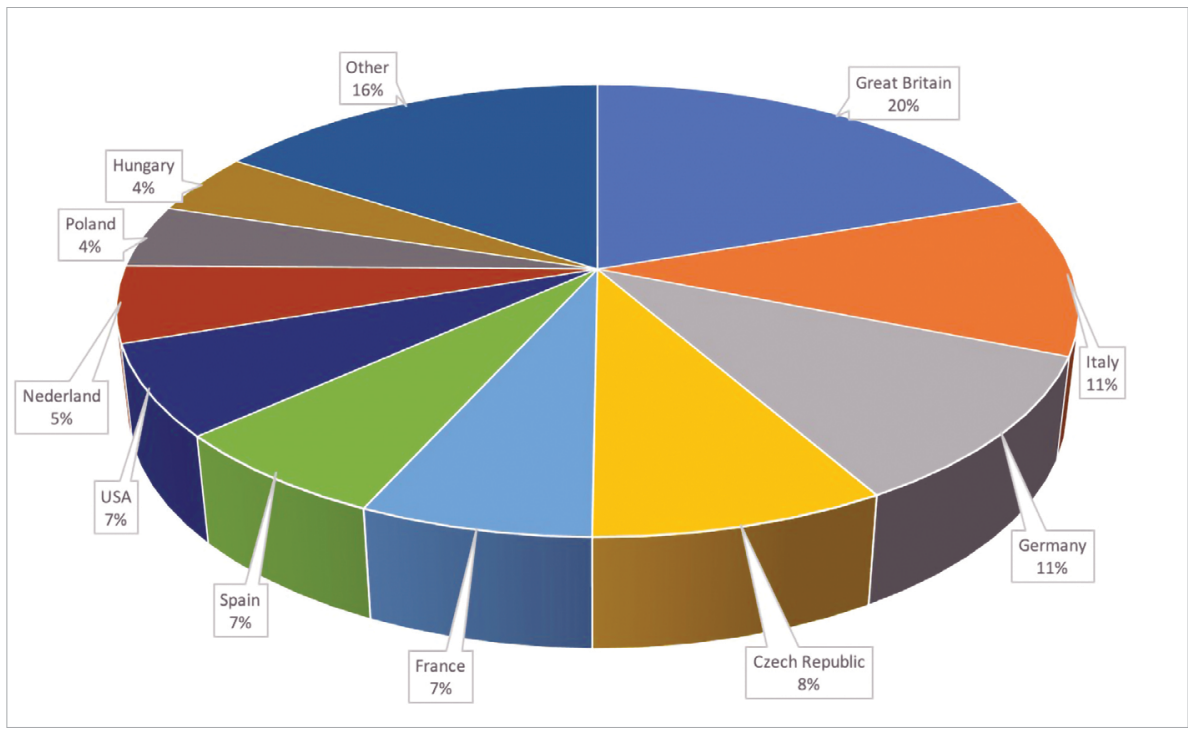

Fig. 6 Share of visitors in Škocjan Caves by country of origin in 2018 Source: Škocjan Caves Public Service Agency, 2019 
Calculation of the carrying capacity of the cave according to visit:

- Length of the classical circular path through the underground canyon $=3,000 \mathrm{~m}$

- Duration of the tour with a guide $=90$ minutes

- The rate of $10 \mathrm{~m}$ of space per visitor on the trail, according to Brijuni National Park in Croatia (Guidelines for Carrying Capacity Assessment for Tourism in Mediterranean Coastal Area, 1996)

- $\quad 3000 \mathrm{~m}$ total $\div 10 \mathrm{~m}$ per visitor $=300$ visitors $\max$ on a thematic pathway simultaneously

- $\quad 300$ visitors $\div 20$ visitors per group $=15$ guides (groups) simultaneously in the cave

- Maximum number of visits to the cave is 18 visits/day, every 30 minutes from 9:00 AM to 17:30 PM

- $\quad 100$ visitors $\mathrm{x} 18$ visits $=1,800$ visitors/day (the carrying capacity of the cave)

- Maximum number of visits to the cave, which may be provided by each guide is 5 visits/day (18 visits every 30 minutes from 9:00 to $17: 30$ )

- 18 visits $\times 15$ guides $\div 5$ guides $=270$ groups $\div 5$ guides $=54$ guides $/$ day needed in the high season

- There are currently only 50 guides in the high season

The decision of the park management regarding the maximum number of 50 visitors per cave guide is, in the opinion of the author, inappropriate. In practice and literature, it is recommended to have guided tours in small groups, max 30 visitors per guide, and 15 visitors per guide are recommended in nature parks (Fenell, 2008). Therefore, more guides should be employed during the summer season, who will be able to carry out not just better interpretation, but also adequate nature protection control.

In order not to exceed the hourly carrying capacity of 200 visitors/ hour, we advise that the park administration create a new schedule of cave visits in the summer. Given that a visit to the cave lasts 90 minutes, it would be more appropriate to anticipate cave visits every half hour, when up to 100 new visitors could enter the cave. This would make it easier to get closer to the norm of the maximum of 300 visitors at a time in the cave. The calculation of the cave's carrying capacity with visits to the cave every half hour and extending daily working hours by 1.5 hours shows that the maximum 
number of tourists who could visit the cave is 1,800 . For 1,800 visitors a day, 54 guides should be provided instead of the current 50 guides, considering the ideal maximum of 20 visitors per guide.

With the existing schedule of visits to the cave at each hour and 240 visitors per hour at the peak of the summer season, the park significantly exceeds its carrying capacity and the target set in the work report for 2018 (Škocjan Caves Public Service Agency, 2019) which is a maximum of 130 visitors every half hour. In the summer season of August 2019, the capacity of the cave was exceed on 13 days (Fig. 7).

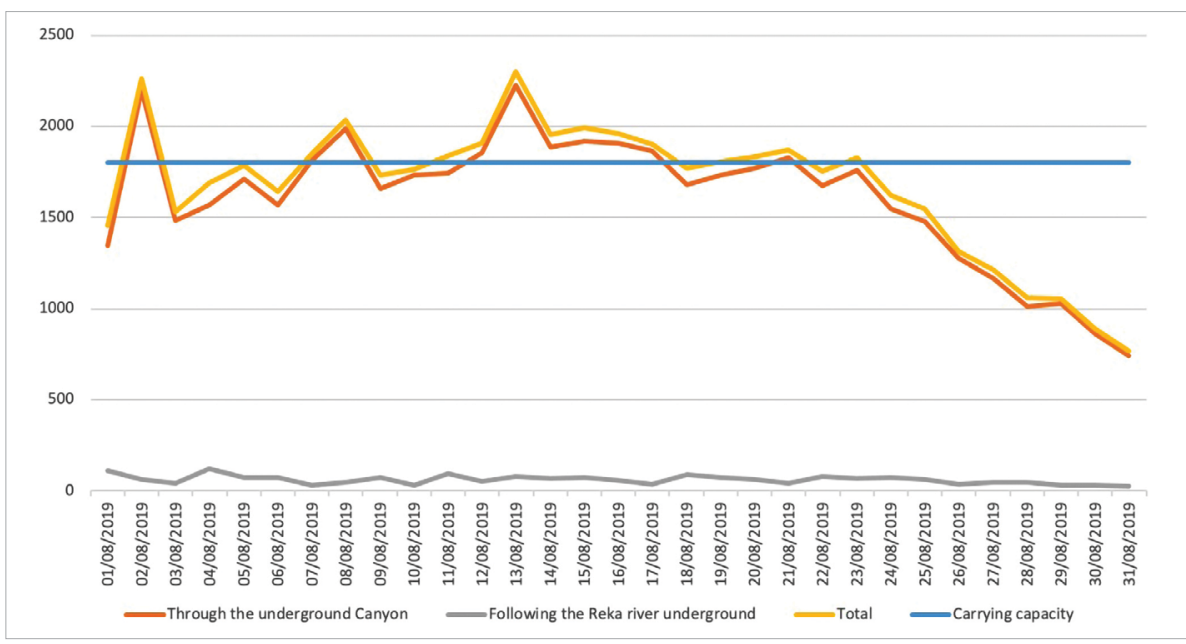

Fig. 7 Number of visitors per day in Škocjan Caves in August 2019

Source: Škocjan Caves Public Service Agency, 2019

\section{Conclusion}

Within the spatial planning process, we must identify and seek to reduce any conflicts that may arise between the different stakeholders in a given protected area. With the introduction of the process of spatial planning in protected areas in Slovenia, we found that tourism supports and does not necessarily reduce the quality of life of local residents, when local communities are involved in the planning of tourism and recreation in the area. An integrated planning and management approach can provide good longterm communication between park management authorities, local residents, and visitors. We propose further application of internationally established concepts and tools which are critical for successful spatial planning 
of tourism as well as for a better understanding of its impacts, in order to aid in mitigating potential problems.

Tourism carrying capacity assessments (Jurinčič, 2009; Jurinčič and Balažič, 2011) are a useful tool, based on the perception that tourism cannot continually grow in a protected area without causing irreversible damage to the local system. Furthermore, strategic environmental assessments and environmental impact assessments can be helpful decision-making processes used to promote good environmental planning by assessing the potential effects and benefits of tourism activities on the environment.

Protected areas generally cover several municipalities and require inter-municipal spatial planning of appropriate activities. Therefore, in Slovenia, the re-establishment of a system of regional spatial planning, which would provide a comprehensive and long-term solutions for sustainable planning and management of protected areas, is needed. This can be seen in new spatial planning legislation that is now public (Law on Spatial Planning, 2017). Until we establish administrative regions and their governing bodies in Slovenia, we suggest that the role of preparing regional spatial plans be taken by regional development agencies and their spatial planning experts. The role of regional governmental bodies in confirming regional spatial plans in this transitional period-the councils of the twelve developmental regions of Slovenia-would be assumed by those who have experience with the certification of regional development programmes from periods 2002-2006, 2007-2013, and 2014-2020. This would provide the necessary conditions for the transfer of competences from the national to the regional level to introduce a "bottom-up" process of spatial planning.

\section{Acknowledgements}

The author would like to thank Mrs. Jana Martinčič from the Škocjan Caves Public Service Agency for contributing data and information.

\section{References}

Balažič, G., Jurinčič, I., Sinkovič, L., 2011: Naravni rezervat Škocjanski zatok kot del integralnega turističnega proizvoda, in: Razvoj zavarovanih območij v Sloveniji (eds. Nared, J. et al.), Knjižna zbirka Regionalni razvoj, Založba ZRC, Ljubljana, 53-61. 
Bartol, B. (ed.), 2004: Strategija prostorskega razvoja Slovenije - SPRS, Ministrstvo za okolje, prostor in energijo, Direktorat za prostor, Urad za prostorski razvoj, Ljubljana.

Cigale, D., Lampič, B., Mrak, I., 2010: Turistični obisk in zavarovana območja - primer Triglavskega narodnega parka, Dela 33, 75-96, DOI: 10.4312/ dela.33.5.75-96.

Fennell, D. A., 2008: Ecotourism, Routledge, London.

Jurinčič, I., 2009: Nosilna zmogljivosti Slovenske Istre za turizem, Fakulteta za turistične študije Portorož Turistica, Portorož.

Jurinčič, I., 2011: Landscape evaluation on a regional level for sustainable tourism development, in: Sustainable World (eds. Brebbia, C. A. et al.), WIT Press 142, Southampton - Boston, 619-628, DOI: 10.2495/SW100561.

Jurinčič, I., Balažič, G., 2011: Determining the carrying capacity of the Škocjan Caves Park for the implementation of sustainable visitor management, in: Tourism and quality of life, international conference proceedings, 3 rd Days of Turistica Encuentros (eds. Jere Lazanski, T. et al.), Fakulteta za turistične študije - Turistica, Portorož, 205-215.

Jurinčič, I., Bojnec, Š., 2007: Natural park as a brand name: Dragonja's valley in Slovene Istra, in: Strategic development of tourism industry in the 21th century: conference proceedings, Faculty of Tourism and Hospitality, Ohrid.

Jurinčič, I., Bojnec, Š., 2009: Environmental management in Slovenian tourist enterprises, International Journal of Sustainable Development and Planning 4 (3), 226-237, DOI: 10.2495/SDP-V4-N3-226-237.

Jurinčič, I., Bojnec, Š., Vodeb, K., Bošković, D., 2007: Management of natural parks for successful tourism development, in: Management International Conference (MIC) 2007 (eds. Bojnec, Š. et al.), Faculty of Management Koper, University of Primorska, Koper, 951-962.

Podmenik, D., Jurinčič, I., Balažič, G., Horvat, A., Kerma, S., 2012. Turizem na ekoloških kmetijah v Sloveniji, in: Trendi in perspektive ekološkega kmetijstva s poudarkom na Sloveniji in Slovenski Istri (eds. Podmenik, D et al.), Vega, Ljubljana, 129-142.

Potočnik Slavič, I., Cigale, D., Lampič, B., Perpar, A., Udovč, A., 2016: (Ne) raba razpoložljivih virov na kmetijah $v$ Sloveniji, Znanstvena založba Filozofske fakultete, Ljubljana.

Smrekar, A., Kolar Planinšič, V., 2009: Vloga celovite presoje vplivov na okolje za ugotavljanje trajnostnega razvoja na primeru Kobilarne Lipica, in: Regionalni razvoj 2, Razvojni izzivi Slovenije (eds. Nared, J., Perko, D.), GIAM ZRC SAZU, Ljubljana, 91-101. 
Vidmar, B., 2004: Škocjanski zatok: priložnost za naravoslovni turizem tik ob mestu Koper, in: Zavarovana območja in njihov pomen za turizem: morska učna pot Mesečev zaliv in njegovi zakladi (ed. Gosar, A.), Univerza na Primorskem, Koper, 62-65.

\section{Sources}

Directive 2001/42/EC on the assessment of the effects of certain plans and programmes on the environment (SEA Directive), https://ec.europa.eu/environment/eia/sea-legalcontext.htm (11. 10. 2019)

Guidelines for Carrying Capacity Assessment for Tourism in Mediterranean Coastal Area, UNEP/MAP/PAP, Split, 1996.

Insight into the procedures for the preparation of state spatial planning acts (Vpogled v postopke priprave državnih prostorskih aktov), Ministrstvo za okolje in prostor, http://www.mop.gov.si/si/delovna_podrocja/prostorski_nacrti/drzavni__prostorski_nacrti/vpogled_v_postopke_priprave_ drzavnih_prostorskih_aktov/ (11.11. 2019)

Law on Spatial Planning, 2017: Uradni list RS, 61/17.

Ordinance on the regulatory plan for the area of the Škocjanski zatok Nature Reserve (Odlok o ureditvenem načrtu za območje naravnega rezervata Škocjanski zatok), 2002: Uradni list RS, 119, 16734-16741.

Slovenian Environment Agency, 2019a: Natura 200o, http://kazalci.arso.gov. si/?data= indicator \&ind_id=333 (11. 10. 2019)

Slovenian Environment Agency, 2019b: Protected areas, http://www.arso.gov. si/narava/zavarovana\%2oobmo\%C4\%8Dja/ (11. 10. 2019)

Spatial Planning Act, 2007: Uradni list RS 33/07.

Škocjan Caves Public Service Agency, 2019: Poročilo o delu Parka Škocjanske jame, Slovenija za leto 2018, https://www.park-skocjanske-jame.si/file/ download/249_5a371317c852 (11. 11. 2019) 



\title{
Chapter io
}

The interrelation between development, management, and management issues in Plitvice Lakes National Park

\author{
Izidora Marković Vukadin
}

\section{Abstract}

The implementation of the first management system for Plitvice Lakes coincided with the founding of the Park and its associated management body in 1949. Since then, the area of the Park has been managed by various public institutions, founded for the purpose of preserving its natural and cultural value. The area's development as a tourism destination has resulted in many developmental missteps, as well as management issues and other challenges. The problems associated with managing protected areas can be seen by analysing the goals that have been achieved by past management bodies, as well as by observing how the current management body is working toward its stated goals (which is not done enough). In terms of development, it is important to emphasise how development policy has largely encouraged hotels and hospitality businesses, while other sorts of businesses lag behind. This has significantly reduced the potential positive effects on the greater community as well as the return of important services of the ecosystem and geosystem to the environment itself. Concordantly, management goals are insufficiently oriented toward the fundamental role of national parks, conservation, and evaluation of natural components in the area. 
Key words: national park, management of protected areas, environment, tourism, geography, Plitvice Lakes National Park, Croatia

\section{Introduction}

In Croatia, typical planning and management practices (especially in tourism) often only promote concepts of integral management and sustainable development in principle, whereby dangers for the environment and human health become marginalised. Due to this, one of the goals of this chapter is to determine all possible negative influences for a given area at the start of the planning process, which is especially important for protected areas (Harding, 2006). Additionally, it is important to establish possible solutions that can be achieved with respect to the specific conditions of a given area, and which are in keeping with sustainable management.

This chapter focuses on Plitvice Lakes National Park, primarily due to the fact that national parks represent generators of development for individual areas (Petrić, 2008; Radeljak and Pejnović, 2008), and are the protected areas that are most visited by tourists. National parks are also typically large in area and are natural areas that are used intensively for tourism. It is also important to mention how protection of national parks is regarded as a fundamental part of protection of biodiversity around the world (Gaston et al., 2006; Mora and Sale, 2011) and, as such, these areas are among the most valuable parts of national territory (Lausche et al., 2013) and number among the most attractive tourism destinations. Therefore, the aforementioned areas must be planned and managed carefully using active measures that are in keeping with sustainable development. This approach requires a detailed analysis of each area's status, from which solutions to potential associated problems can be generated.

Therefore, the basic goal of this chapter is to give a unified view of the developmental phases of Plitvice Lakes National Park in relation to management phases and problems. A recommendation for a conceptual model of integral and sustainable development for the Park is also put forward in this chapter.

\section{Methodological framework}

The method of triangulation, using interviews with management experts, analysis of literature and secondary sources, and a critical assessment of 
existing management plans was used for the purposes of this chapter. Push and pull factors were established, analysed, and compared to existing methods of managing protected areas, creating the basis for the integral management model presented later in the chapter.

The chapter analyses data from the area of Plitvice Lakes National Park, accumulated from statistical, professional, and scientific publications, as well as numerous cartographical and graphical elements. The key sources of data for the research in this chapter, related to the Park, were: Population Censuses of 1991, 2001, and 2011 (Croatian Bureau of Statistics, 1994; 2003; 2013); number of overnight stays; arrivals (visits); and other tourism statistical data from the internal database of the Park and the eVisitor system (2019). Material from the aforementioned phases also represents data on the status of the environment in the area of the Park, stemming from a long line of previously-published research. Finally, two management plans for the Park (from 2007 and 2018 respectively) served as important parts of the base data for the analysis.

In the scope of the research, deep interviews with groups of experts from the domain of management of national parks were carried out. The fundamental theme in the interviews was establishing the efficiency of park management via analysis of 14 specific goals from the management plans of 2007 and 2018 and 18 management sub-plans of 2018. Eight experts from different scientific fields (geology, geography, biology, economy, chemical engineering, forestry, sociology, and architecture) were interviewed.

\section{Fundamental characteristics of Plitvice Lakes National Park}

Plitvice Lakes National Park lies in the mountainous part of the Republic of Croatia (Fig. 1) and encompasses an area of $297 \mathrm{~km}^{2}$. The park contains an exceptionally-sensitive natural phenomenon based on the process of tufa formation ${ }^{\mathrm{I}}$, for which it was named a UNESCO World Heritage site in 1979.

1 Tufa is a result of development of strictly determined interactions between physical-chemical and biological characteristics of a unique karst water basin, in climate conditions of the current interglacial and conditions of undisturbed natural balance (Stilinović and Božičević, 1998). 

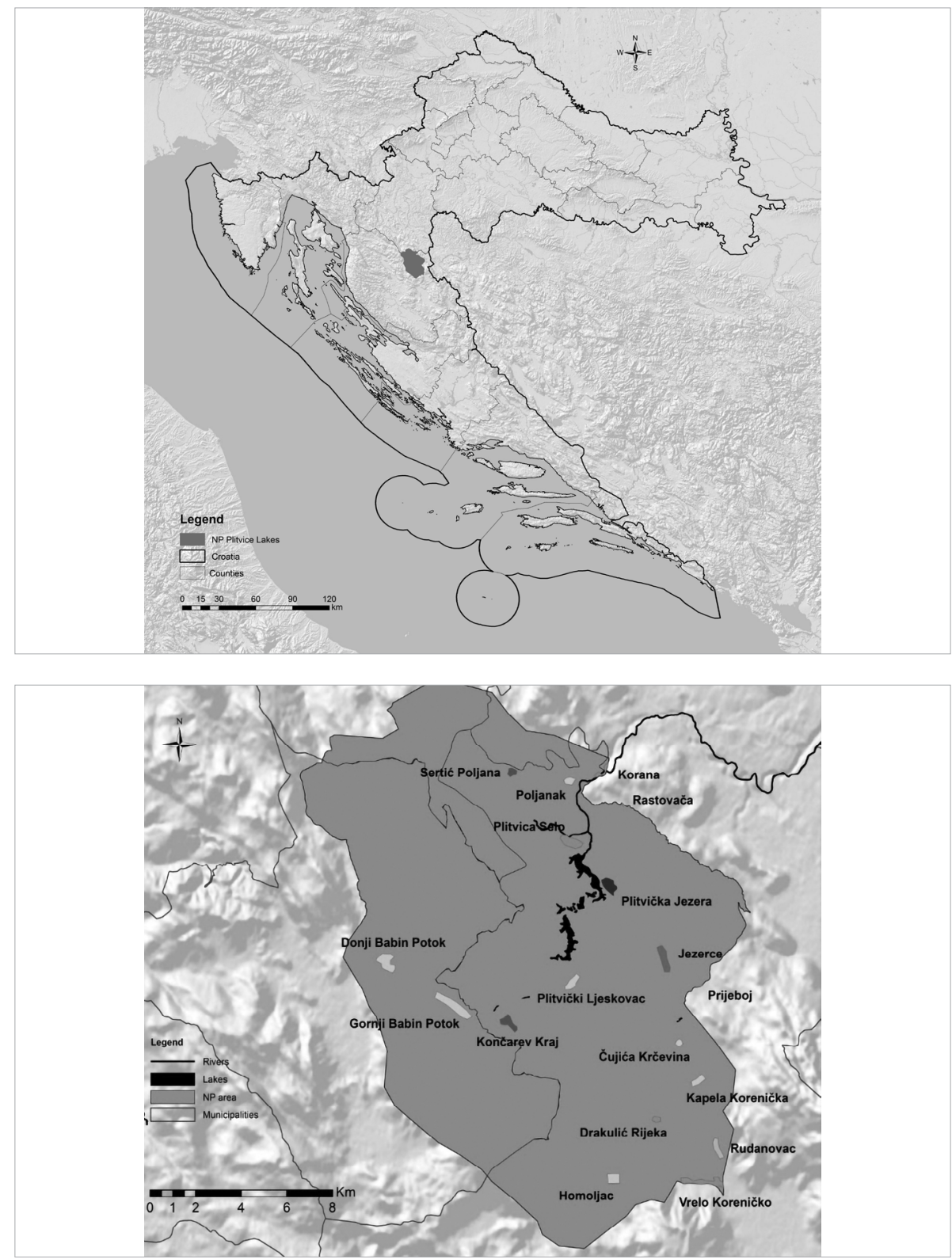

Fig. I Location of Plitvice Lakes National Park in Croatia

Source: State Geodetic Administration of the Republic of Croatia (SGA), 2019 
The area of the Park, however, is increasingly threatened due to an explosion in the number of visitors over the last 20 years (Sremac et al., 2011). Due to this, it is crucial to consider possibilities for managing all elements of the Park with the goal of sustainable development on all levels. The underlying phenomenon that created the park (tufa formation) is a result of a process of strictly-determined interactions of physio-chemical and biological factors of the unique karst aquifer, climatic conditions of the current interglacial period, and the generally-undisturbed natural balance (Stilinović and Božičević, 1998). The formation of tufa is an extremely sensitive process, which can be halted by changes in the environment and environmental conditions, as well as by natural and anthropogenic influences.

For the aforementioned reasons, the need to protect this particular phenomenon became apparent very early (Pevalek, 1924; 1935; 1938; Petrik, 1958; Stilinović and Božićević, 1998). The area of the Park encompasses Plitvice Lakes and the surrounding landscape. Over the last two centuries, the landscape of the park itself has been significantly altered to accommodate modern leisure activities (tourism, recreation, transport) and other anthropogenic activities. Indicators of long-term settlement are the numerous deforested areas, which took shape in the period from the $17^{\text {th }}$ century to the end of the Second World War (Marković, 2015). In keeping with contemporary trends of rural depopulation, protected areas (which are often in zones of rural periphery settlements) are becoming predominantly tourist settlements as tourism strengthens (Lukić, 2012), which is out of synch with the status of the periphery. This has happened in the area of Plitvice Lakes, where intense tourism development has contributed to the stagnating number of residents in the area around the Park itself.

\section{The lifecycle of tourism in Plitvice Lakes National Park}

Starting in the mid-20 ${ }^{\text {th }}$ century (with the exception of wartime discontinuity), the development of the Park, its wider area, and the corresponding socio-economic region took place under the dominant influence of tourism. An indicative fact linked to economic characteristics is how, in 2018, there were 768 full-time employees of the Park, while there were between 130 and 250 temporary employees (depending on seasonal needs) (Plitvice Lakes National Park, 2019), making the Park the largest employer in LikaSenj County.

In keeping with the aforementioned, further development of the Park should be regarded in the context of development that has (with minor dis- 
continuity) taken place over the last 150 years-more specifically, the formal development of the last 70 years. In regard to the processes of protection and connection that began with the founding of the "Society for the Maintenance and Beautification of Plitvice Lakes" in 1883, the area of Plitvice Lakes was "discovered" in a touristic sense around the same time, marking the start of a series of leaps in development that can be divided into six fundamental phases (Marković Vukadin and Franjković, 2019):

1. the research phase;

2. the phase of intense infrastructure development;

3. the phase of reorganisation and spatial expansion;

4. the phase of intense growth in the number of visitors;

5. the wartime phase, i.e. phase of decline-second developmental cycle; and

6. the phase of (re)expansion of visitors-second developmental cycle.

From the end of the $19^{\text {th }}$ century to the end of the Second World War, the area of Plitvice Lakes was characterised by the gradual discovery of its touristic potential. This period represents the research phase in the lifecycle of the area as a destination, when the first tourism-related construction took place. The first hospitality object near Plitvice Lakes was built in Velika Poljana in 1862. It was called the "Tourist House" and would also later gain the role of forester's lodge (Ivanuš, 2010). On the initiative of the Society for the Maintenance and Beautification of Plitvice Lakes in 1886, the first hotel near Plitvice Lakes was built-also in Velika Poljana. Hotel Plitvice was a generator of development for the area, and the opening of the Lika railway line made the area more accessible and spurred the refurbishing of hotels, summer houses, roads and paths, and bridges ${ }^{2}$. Just before the Second World War, the tourism supply also spread to the area of Labudovac and Plitvički Ljeskovac (Petrić, 2008).

The next lifecycle phase of Plitvice Lakes as a destination was the period of intense development (1949-1969), which was characterised by concentration of the bulk of the tourism supply (especially in the area around Velika Poljana) in the early developmental phase of the Park. This also had an influence on the demographic livelihood in the area immediately sur- 
rounding the park (Pejnović, 1992), and resulted in discord between nature protection imperatives and intense (and poorly-controlled) development of tourism establishments. The largest hospitality objects were constructed during this era, e.g. Hotel Plitvice (1953), Hotel Bellevue (1963), and Hotel Jezero (1970) (Marković Vukadin and Franjković, 2019).

As a response to the prior period of growth, a phase of reorganisation followed (1970-1990), which was characterised by numerous qualitative changes based on scientifically well-founded research and solutions. Business and work within the Park itself was united under a single organisation, which allowed its development to be better coordinated. It is important to note how economic and infrastructural projects, for which the basic goal was the dispersion of the tourism supply throughout the wider Lika Region, emerged and played a major role in the preservation of the Park's fundamental phenomenon. This period was characterised by the redistribution of Park resources to the local community and the strengthening of traditional forms of economic activity, by which a balance between nature protection, tourism, and the needs of the local community was attained. This can be seen in the amount of new accommodation capacity that was built from 1975 to 1981, when the development of new accommodation in the Park, and in Lika as a whole, equalised.

It should also be mentioned how this period was still characterised by centralised development of tourism and other functions. In the second half of the 1970s, there was a huge surge in tourist accommodation capacity (Marković Vukadin and Franjković, 2019). Concurrently, there was also a huge surge in tourist visits, which peaked in 1985 (762,221 visitors). This represents the zenith of Plitvice Lakes as a tourist destination prior to the collapse of Yugoslavia and the Croatian War of Independence (1991-1995). After 1985, the Park would slowly slide into a phase of stagnation (Vidaković, 1997).

The next two periods (second developmental cycle) during and following the Croatian War of Independence-the phase of decline and the phase of (re)expansion of visitors-represent a new lifecycle for the Park as a destination, complete with new challenges, problems, and opportunities for tourism development. It should be stressed here that the Park was characterised (unsurprisingly) by a sharp decline in visitors during the War (nearly $100 \%$ ) and the destruction of tourism objects. Therefore, the period of 1997 to the time of writing has been characterised by tourism development and a constant increase in the number of visitors, overnight stays, income, 
and a corresponding increase in conflicts between nature protection and economic imperatives.

Passing the milestone of one million visitors was only the herald of further growth-the number of visitors was 1,188,798 in 2013 and would grow to 1,7 million in 2017 (Fig. 2) The pressure caused by the massive number of visitors is not overly alarming if regarded in terms of average visitors per day, which was 3,093 in 2013 and 4,657 in 2017. In terms of the number of entry passes sold (tracked daily), however, there were 18 days when the Park had over 10,000 visitors, and 62 days with over 8,000 in 2013, while in 2017 there were 56 days when the Park had over 10,000 visitors (Plitvice Lakes National Park, 2018) ${ }^{3}$.
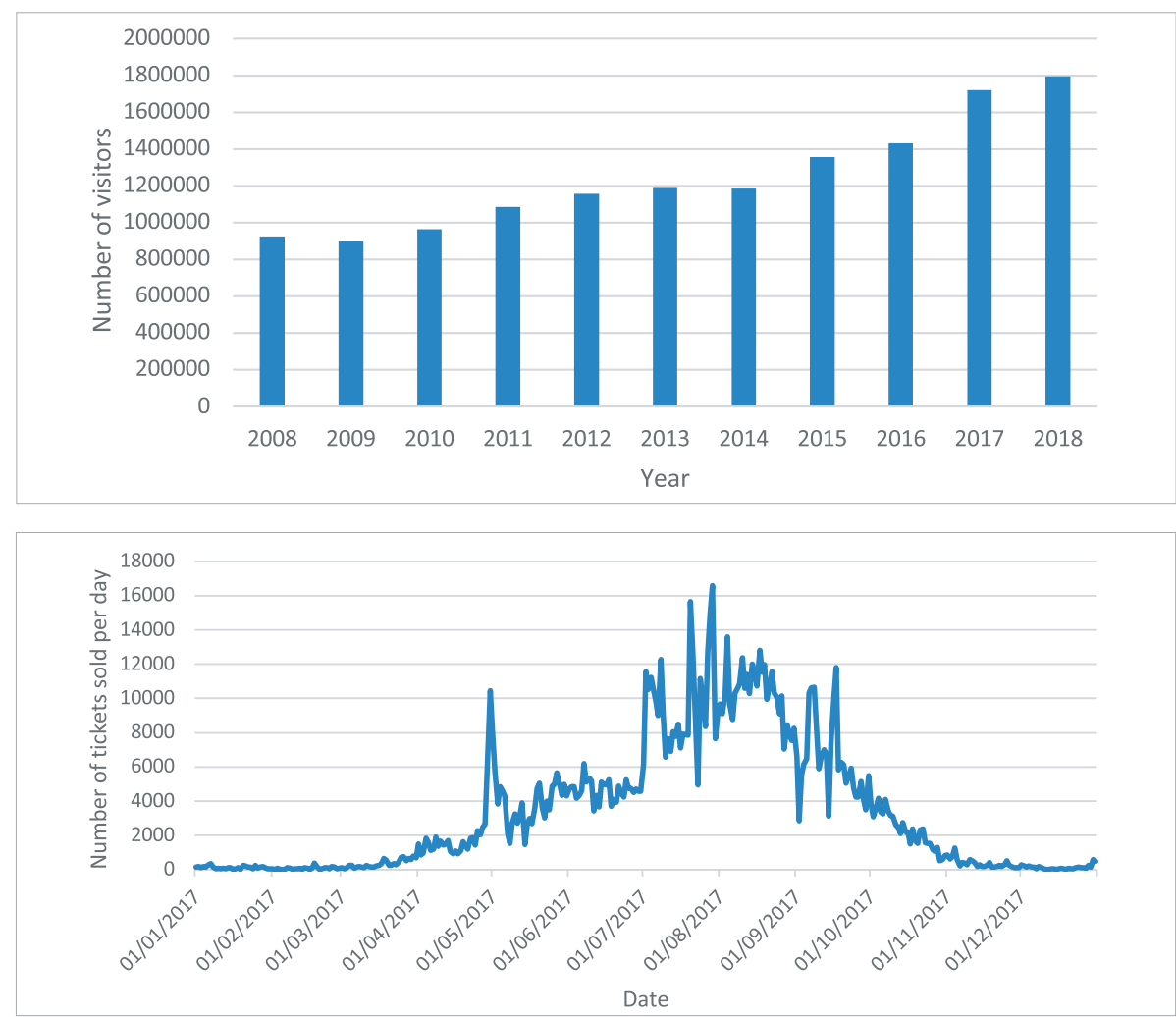

Fig. 2 Yearly and daily fluctuation in the number of visitors to Plitvice Lakes National Park in 2017

Source: Plitvice Lakes National Park, 2018

3 The introduction of a new system of ticket reservations, starting on April 1st, 2019, set the daily entrance limit for the Park at 10,000, which should prevent further 
It is important to emphasise how the aforementioned numbers exclusively regard visitors to the zone of the fundamental phenomenon of the Park, which is near the two main entrance points. Excess and (spatially and temporally) discordant development of tourism in the Park is an increasingly severe threat to the sustainable development of the area, whereby special attention should be given to the atrophied settlement structure, the corresponding weakening of traditional local identities and the multi-faceted, unique localities within the Park, as well as processes of anthropogenic eutrophication.

Contemporary tourism development-in the second developmental cycle-in terms of spatial transformation has been characterised by intense growth in the number of private accommodation objects, which has had a tendency to encroach on the most sensitive parts of the Park (e.g. Plitvica Selo along the Plitvica River-which is the source of the large waterfall). Thus, the amount of private accommodation has grown with the number of visitors over the last 20 years, especially in the immediate area of the Park. The aforementioned Plitvica Selo, which has recorded the highest level of growth in private accommodation, should not be allowed to undergo a new phase of tourism urbanisation that would be characterised by the construction of new objects as well as the renewal of existing ones.

Private accommodation has expressly seasonal characteristics, and its demands, particularly on the water supply during summer months, heavily burden the area's resource base. Furthermore, this burdens the drainage and sewer systems, as well as the area's waste management capacity (Opačić et al., 2005). The scope of the problem becomes clearer when it is regarded in terms of the spatial distribution of private accommodation within the Park, in which the immediate area of the National Park is especially pressured.

Finally, it should be pointed out that, in keeping with knowledge gained from the last few decades of overuse of the Park's resources, this phase of expansion could mature into a new phase of development that would be oriented toward improving the quality of the existing tourism supply and increasing awareness of the area's value via education (regarding the environment as well as the traditional significance of Plitvice Lakes and its surroundings). This would go hand in hand with renewing existing hospitality objects in the area of the Park, building more recreational paths,

eutrophication of the environment of the lakes. This is also in the interest of providing a better experience for visitors as crowding is reduced. 
as well as forming a unified concept of the Park, as both a protected nature area with its own local tradition and history and as a world-renowned tourist destination.

\section{Management and its contribution to sustainable development of Plitvice Lakes National Park}

The main determining element for continued management on all levels of the Park is the fact that it is still centrally-managed, based on the decision made by the competent state institution, i.e. state governance. This type of management, however, has more to do with management policy than actual management methods-which will hereinafter be described.

The start of management and general social awareness regarding Plitvice Lakes coincided with the founding of the Society for the Maintenance and Beautification of Plitvice Lakes in 1883 (Vidaković, 1997), marking the beginning of organised action that can be understood as a forerunner to the contemporary management system. The first management system for the Park was implemented when the Park was officially formed in 1949. In this period (1949-1969), the Park was managed by several different management bodies.

In 1970, a single organisation-called National Park Plitvice, enterprise for nature protection, hospitality, tourism, and commerce-took over management of the Park. This organisation acted as the Park's management body and was very successful at achieving determined goals, despite the lack of management plans that have (in Croatia) come to be regarded as the most important pieces of documentation for the management of a given area. It continued to operate successfully up until Croatian independence, and managed the area primarily via spatial planning documents (Petrić, 2012):

- Plitvice-Regional Plan, 1950;

- Programme of the General Urban Plan, 1960;

- General Maintenance Plan, 1971;

- Recommendation for the Spatial Plan of Plitvice Lakes National Park, 1975;

- Spatial Plan for Plitvice Lakes National Park: spatial plan for an area of special purpose, 1986.

After wartime occupation and the return of the local populace and reinstatement of the Park's management structure, visitors also returned. At 
this point, the main task of management was to restore damaged objects while managing existing tourism. The obligation to create management plans for protected areas was written into law for the first time with the Law on Nature Protection of 2003. Management plans determined management goals and activities, how to reach them, and indicators by which the efficiency of management would be measured. These plans are made for tenyear periods, with an option to update/replace them after five years, and are implemented via yearly programmes for protection, preservation, use, and promotion of protected areas.

The management plan for Plitvice Lakes National Park of 2007 is among the most important documents in Croatia on this particular strategic level. The plan consists of a summary of strategic documentation by which strategic orientation and management goals are to be determined, as well as individual parts of action plans that go deep into detail regarding management orientation and management methods to be used in the field. Based on the aforementioned, four fundamental phases of management of the area were identified (Fig. 3):

1. the phase of informal management (1883-1948);

2. the phase of management based on spatial plans (1949-1989);

3. the wartime phase-lack of a fundamental management and decision-making body (1990-2002); and

4. the phase of planned management documents (2003-time of writing).

In order to evaluate the Park's management, its fundamental goals should be listed (Plitvice Lakes National Park, 2007):

- preserve the unique karst biological diversity by ensuring that natural processes remain undisturbed, and ensuring protection to the area by minimising human impacts;

- cooperation between the local community and the Park's management in terms of planning and implementation on the local level; and

- ensuring that visitors receive a genuine experience of the natural riches of the Park.

The fundamental goals for long-term sustainable management of the Park have been laid out in the management plans, whereby the focus is on continual preservation of the landscape and its biodiversity, cultural herit- 


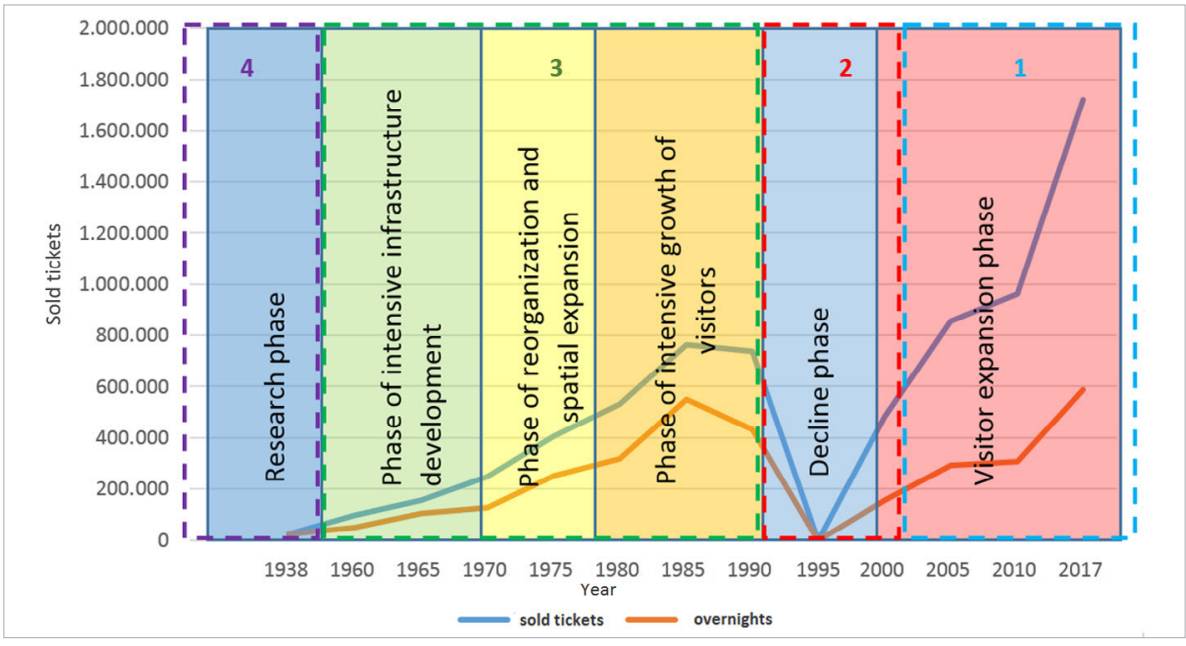

Fig. 3 The lifecycle of Plitvice Lakes National Park as a tourism destination and its management phases

Source: according to Marković Vukadin and Franjković, 2019, adapted by author

age, promotion of awareness of the importance of nature and cultural heritage preservation, preserving the pristine nature and other attractions of the Park, and strengthening the local community. A number of specific developmental goals were determined based on these fundamental goals, from which the final action plan was determined. The specific goals for biodiversity preservation and the development of tourism are of particular interest:

1. the goal of managing the forests of Plitvice Lakes National Park is to ensure the natural state of the forest ecosystem, which are of crucial importance for biodiversity and the preservation of the fundamental phenomenon, and to ensure all generally-useful functions of the forest;

2. preservation of positive trends of the development of tufa formations of the river community and tufa conditions on tufa barriers, and ensuring the preservation of all plant and animal communities in the aquatic ecosystem (source, standing, and flowing waters) in order to preserve biodiversity and the ecological balance;

3. preservation of grasslands (dry pastures and meadows, wet pastures and meadows, and marshes) as areas of great biodiversity and value to the landscape; 
4. systematic research, preservation, and presentation of cultural heritage and preservation of the entire rural area and traditional production methods (agriculture, herding, trades and crafts);

5. gathering of sufficient data regarding all elements of the protected area (biotopes and species as well as other elements that do not belong to the domain of natural sciences research but are important for the purposes of management, e.g. cultural heritage, etc.) in order to better and more easily manage the area of the National Park;

6. enabling visitors to have a quality visit, with a high level of organisation and a minimal possibility of damaging the ecological system of Plitvice Lakes;

7. understanding of the value of Plitvice Lakes as a natural phenomenon on the part of all employees, the local population, and visitors, while enabling a high level of enjoyment of the natural area and quality services;

8. improving the quality of accommodation and services in the area of Plitvice Lakes National Park, while respecting the highest ecological criteria along with maximising use of local and regional resources according to the relevant spatial plan;

9. improving the image of Plitvice Lakes National Park and the level of general knowledge regarding its natural and cultural value;

10. regulation of traffic in accordance with the fundamental purpose of Plitvice Lakes National Park and the needs of stakeholders;

11. development of infrastructure that has a minimal effect on the environment;

12. establishment of cooperation with the local population in order to achieve the vision of Plitvice Lakes National Park;

13. resolution of legal-property issues within Plitvice Lakes National Park with special attention given to co-ownership relations for the duration of the current plan; and

14. improvement of the legal framework for the effective management of Plitvice Lakes National Park.

With the expiration of the prior plan came the obligation to create a new management plan for the Park for the period of 2019 to 2028, however, this plan has yet to be accepted and is still in its final draft form (that is available for public discussion) at the time of writing. In terms of its contents, the new plan is in keeping with documentation from 2018 (Ministry 
of Environment and Energy and the Republic of Croatia and Croatian Agency for the Environment and Nature, 2018) regarding orientation and planning for protected areas and/or areas of ecological networks, and the best practices of European management plans. The management of the Park is planned via five main themes, for which general goals and activities have been defined by evaluation and grouped into subthemes.

For each planned activity the following has been determined: implementation priorities; schedule of implementation; expected cooperation with partners and institutions in goal implementation; and an evaluation of expected implementation expenses (normal expenses for Park business, e.g. employee payroll, are not included in this evaluation). In total, 556 activities were determined and grouped into 18 subthemes within the five general themes. In comparison to the former plan, the determination of the aforementioned five themes with their respective subthemes (listed below) is a major change (Plitvice Lakes National Park, 2018).

A. Preserved species diversity, biotopes and karst forms, as well as the stable process of tufa formation ensure the preservation of the unique beauty of the natural landscape, and also the preservation of the unique, universal value of the Park for current and future generations. Subthemes: preservation of aquatic ecosystems; preservation of forest ecosystems; preservation of grasslands; and preservation of karst.

B. Preserved cultural heritage has an important role in presenting the value of the Park and contributes to preservation of the traditions and cultural identity of the area. Subthemes: tangible cultural heritage; intangible cultural heritage; and cultural landscapes.

C. A full and unhindered experience that does not damage the values of the Park must be enabled for all visitors, which will best present preserved world heritage, create the income needed for its upkeep, generate public support for nature preservation, and create opportunities for sustainable development of the local community. Subthemes: visitation system; hospitality and commerce; interpretation and education; and marketing.

D. The local community is the main partner of the Public Institution in management of the Park and preservation of its values and the Park is recognised as a constituent part of the identity of the local community, and development of the local community based on sus- 
tainable usage is an opportunity that preservation of a world heritage site offers. Subthemes: revitalisation of agricultural production; development; and harmonisation of the ecotourism supply.

E. The competent Public Institution will apply all needed legal, organisational, human, and material capabilities, resources, and power in order to manage the Park and continually work toward its improvement in all segments of management and organisational culture, strengthening cooperation with stakeholders and the role of the Park's management in Croatian and international professional and scientific circles. Subthemes: ensuring the legal and planning framework needed for proper management; development of institutional and human potential and competence; and management of property and infrastructure.

Effectiveness of the aforementioned goals and themes from both the former and proposed plans will be analysed in sections below, with respect to their focus on the basic problems faced by the Park and how to solve them.

\section{Management problems that have been identified}

In order to establish the state of the environment, area, and community, a wide selection of scientific literature from various scientific fields was analysed with the goal of establishing the key problems faced by the Park. A large number of problematic areas were identified via preliminary synthesis of secondary sources, however, only the themes listed below were selected due to the need for rapid reaction and resolution.

\section{Functional overburdening}

The number of visitors exceeds the number of local residents of the area. This can cause social pressures on the community that, with regard to its weak demographic potential, is not large enough to ensure a steady tourism supply without daily commuters and a constant flow of newcomers. In terms of employment, the number of workers who live in other regions and commute to work in the $\mathrm{Park}^{4}$ or in corresponding tourism objects is increasing. This creates a situation where the community is, apart from the large number of tourist visits and itinerant workers, suffering increasing

4 Of employees of the Public Institution of the Park in 2013, 7\% commuted from other regions (Marković, 2015). 
social pressure as older property and buildings are being sold off and adapted to the needs of tourism or temporary residentss. There are a number of other negative effects, ranging from overcrowding in the main pedestrian areas of the Park (and on the county road that goes through it), to problems for the local community that arise from nature protection imperatives and restrictions (Marković, 2015).

A good example of such an issue for the local community is that construction in the village Korana is restricted and access to certain roads and paths, traditionally used by the local community, has also been restricted. Functional overburdening is seasonal in the area of the Park, echoing tourism demand. The Park has experienced unequal development throughout and, as a consequence, the number of visitors puts immense pressure on the existing public infrastructure, which is insufficient for the relatively-modest needs of the local community alone (much less for tens of thousands of tourists). This has serious negative effects on the surrounding environment.

\section{Threatened hydrological elements of the environment}

According to the latest research, a certain amount of change has been noted in the fundamental physio-chemical process of tufa formation and catalysed biological processes in relation to prior research. According to Pribičević et al. (2011), areas where tufa formation has stalled or slowed have been identified. The research demonstrated how the increased amount of dissolved organic substances (pollution) in the water has halted or hindered the process of tufa formation in the fundamental phenomenon of Plitvice Lakes.

Additionally, there is the process of eutrophication or of aging lakesthis is a natural process that lasts for centuries, but humans can accelerate it greatly with their actions (agriculture, herding, tourism, traffic, waste water) (Stilinović and Božičević, 1998; Marković, 2015). Plitvice Lakes are currently overgrown with marsh vegetation and the lake bottoms are covered with aquatic grasses (Pribičević et al., 2011). Looking at the available biochemical data, it can be concluded that Plitvice Lakes are undergoing a process of anthropogenic eutrophication. Measurements of the flow on Kozjak since 1954 show a continual reduction over the last 60 years of

5 As a consequence, there is a certain kind of class difference between "newcomers" who have capital and the local community, which feels less of the positive effects resulting from the Park. 
$\sim 0.03 \mathrm{~m}^{3}$ per year (Barešić, 2009; Bonacci, 2013). In other words, water is held in the lakes longer and the hydrological system of the lakes is becoming more closed.

\section{Threatened biotopes and changes in land use}

Biotope diversity of forest ecosystems-which humans have damaged by supressing forests - has enabled the development of different types of grasses and other types of ecosystems. Today, however, a large part of the area (primarily grasslands) of the Park is becoming overgrown. From both a floral and vegetation diversity viewpoint, as well as from the perspective of an anthropogenic landscape, this is a negative process because it reduces biodiversity and the richness of the existing flora (Šegulja, 2005). Marsh biotopes and their vegetation are also threatened. There are years of built-up remains of decayed vegetation in some places, which is causing the ground to gradually rise and the biotopes to narrow.

All of the aforementioned shows the emergent need to protect grassland areas, as well as other swamp vegetation areas and marsh biotopes in the Park. Only in this way will the existing biodiversity within the Park be preserved. In order to reach these goals, anthropogenic influence must be restored to a portion of the grassland areas (Fuller et al., 2019), i.e. the grasslands in certain areas of the Park should be regularly mowed.

\section{Negative demographic processes in the Park and its surroundings}

The fundamental cause of depopulation in the area of the Park during the second half of the $20^{\text {th }}$ century was emigration, which was in turn caused by the backwardness and stagnation (in terms of socio-economic development in Croatia) of the wider area. This is supported by the predominance of emigrational types of general population mobility from 1971 to 1991, from both the immediate and wider areas of the Park. The analysis of general population mobility shows a clear difference in the intensity of emigration from the immediate and wider areas of the Park during the last few decades, whereby the immediate area of the Park-thanks to its more developed work functions-has a lower rate of emigration than the wider area (Tab. 1). 
Tab. I Types of general population mobility of the immediate and wider area of Plitvice Lakes National Park by intercensal period (197I-201I)

\begin{tabular}{|c|c|c|c|c|c|c|c|c|c|}
\hline \multirow{2}{*}{ Period } & \multirow{2}{*}{ Area } & \multicolumn{4}{|c|}{ Emigration $^{6}$} & \multicolumn{4}{|c|}{ Immigration $^{7}$} \\
\hline & & $\mathrm{E}_{1}$ & $\mathrm{E}_{2}$ & $\mathrm{E}_{3}$ & $\mathrm{E}_{4}$ & I1 & $\mathrm{I}_{2}$ & $\mathrm{I}_{3}$ & $\mathrm{I}_{4}$ \\
\hline \multirow{3}{*}{$1971-1981$} & Immediate area & & & & & & & & \\
\hline & Wider area & & & & & & & & \\
\hline & Total area & & & & & & & & \\
\hline \multirow{3}{*}{ 1981-1991 } & Immediate area & & & & & & & & \\
\hline & Wider area & & & & & & & & \\
\hline & Total area & & & & & & & & \\
\hline \multirow{3}{*}{$1991-2001$} & Immediate area & & & & & & & & \\
\hline & Wider area & & & & & & & & \\
\hline & Total area & & & & & & & & \\
\hline \multirow{3}{*}{$2001-2011^{8}$} & Immediate area & & & & & & & & \\
\hline & Wider area & & & & & & & & \\
\hline & Total area & & & & & & & & \\
\hline
\end{tabular}

Sources: Croatian Bureau of Statistics, 1994; 2003; 2013

The analysis of general population mobility shows a clear difference in the intensity of emigration between the immediate and wider areas of the Park over the last few decades. This is a result of the War and consequent developmental difficulties, stemming from the beginning of the 1990s, causing depopulation to spread to the settlements in its immediate area. This is a fundamental feature of recent demographic development. Thus, thanks to more developed work functions, the immediate area of the Park has experienced a lower intensity of emigration than the wider area. The problem of "demographic extinction" is not a new occurrence in the

6 E1) emigration, E2) depopulation, E3) expressed depopulation, E4) extinction.

7 I1) expansion via immigration, I2) regeneration via immigration, I3) weak regeneration via immigration, I4) very weak regeneration via immigration.

8 In contrast to the previous 40-year period, the available statistical data for the last intercensal period (2001-2011) were not dependable indicators of general population mobility. Namely, the 2011 Census registered returnees (war refugees) as permanent residents, of whom a smaller proportion (mostly the elderly) actually returned, while the vast majority were not permanent residents. 
Lika and Kordun regions, however, it is a theme that is outside of the scope of management concerns for the Park.

\section{Relevance and efficiency of management documentation}

Martinić (2010) pointed out the lack of a central agency tasked with protected areas/national parks, that would manage the implementation and oversight of existing management plans, as a key problem in Croatian management of protected areas. The problem with managing protected areas, however, is much deeper and can be seen via analysis of attained management goals. The basic tool for measuring efficiency of protection is a method known as "Management Effectiveness Tracking Tools" (METT). This method is widely accepted and often used for determining influences and for reporting regarding management efficiency and effectiveness (WWF, 2007).

The lack of methodology presents certain problems, such as the fact that some protected areas are very general (non-specialised), as well as problems connected to the recognition of specific influences, problems, and the level of success of certain management actions. This problem shows the lacking transparency of data and the possibility of subjective assessment (Canteiro et al., 2018), in regard to the fact that the forms for assessing the success of a given management body are (astoundingly) sometimes filled out by members of the very management body that is being assessed.

Due to the aforementioned problems with objectiveness in the assessment of management, scores were chosen based on interviews with scientists and experts (who have dealt with the problems faced by the Park for years) in order to assess the efficiency of the Park's management. This allowed us to have an approach to assessment that was both multi-disciplinary and objective. The interviewed scientists were from the following fields of study: biology; architecture; social geography; chemical engineering; forestry; geology; and tourism.

The respondents analysed management goals from the 2007 management plan and the outline of the 2018 management plan with the main intent of determining the extent to which the goals were focused on real management problems and how successful they were at achieving their aims. The current management transition period and expansive growth in the number of visitors were taken into account in the experts' assessments. General scores were given, grading how focused the management goals were on the most relevant problems for the Park, as well as scores grad- 
ing how successful said goals were during the period that they were actively pursued (Tab. 2). Apart from scores, the respondents also shared their thoughts on individual goals and in regard to the advantages and disadvantages of the existing management model.

Accordingly, the respondents found that the majority of the goals were insufficiently-relevant and unfulfilled, which is exceptionally important in terms of efficiency of management. Of the 14 goals, six were deemed irrelevant, unnecessary to have as a general goal, or as goals that the management body can and/or should direct resources to achieve, four were deemed partially-relevant, and the remaining four were deemed relevant in relation to the management problems faced by the Park. Furthermore, in terms of the successful achievement of management goals, a high level of inefficiency in management was indicated, such that only one goal was completely achieved, while five were partially-achieved, and the remaining eight goals were not achieved, in the opinion of the respondents.

As the new management plan for the period of 2019 to 2028 has yet to be formally adopted at the time of writing, the respondents were not able to assess it as they had the previous plans, rather they examined the relevance of the new goals and themes and how they related to the goals of previous management plans (Tab. 3).

Tab. 2 Scores of relevance and successful achievement of management goals (R-relevance, P-level of successful achievement) ${ }^{9}$ in Management Plan for Plitvice Lakes National Park, 2007

\begin{tabular}{|c|c|c|c|c|c|c|c|c|c|c|c|c|c|c|c|c|}
\hline \multirow{2}{*}{$\begin{array}{c}\text { Management } \\
\text { goal }\end{array}$} & \multicolumn{2}{|c|}{$\begin{array}{l}\text { Respon- } \\
\text { dent } 1\end{array}$} & \multicolumn{2}{|c|}{$\begin{array}{l}\text { Respon- } \\
\text { dent } 2\end{array}$} & \multicolumn{2}{|c|}{$\begin{array}{l}\text { Respon- } \\
\text { dent } 3\end{array}$} & \multicolumn{2}{|c|}{$\begin{array}{l}\text { Respon- } \\
\text { dent } 4\end{array}$} & \multicolumn{2}{|c|}{$\begin{array}{l}\text { Respon- } \\
\text { dent } 5\end{array}$} & \multicolumn{2}{|c|}{$\begin{array}{l}\text { Respon- } \\
\text { dent } 6\end{array}$} & \multicolumn{2}{|c|}{$\begin{array}{l}\text { Respon- } \\
\text { dent } 7\end{array}$} & \multicolumn{2}{|c|}{$\begin{array}{l}\text { Respon- } \\
\text { dent } 8\end{array}$} \\
\hline & $\mathrm{R}$ & $\mathrm{P}$ & $\mathrm{R}$ & $\mathrm{P}$ & $\mathrm{R}$ & $\mathrm{P}$ & $\mathrm{R}$ & $\mathrm{P}$ & $\mathrm{R}$ & $\mathrm{P}$ & $\mathrm{R}$ & $\mathrm{P}$ & $\mathrm{R}$ & $\mathrm{P}$ & $\mathrm{R}$ & $\mathrm{P}$ \\
\hline $\begin{array}{l}\text { Forest ecosys- } \\
\text { tems }\end{array}$ & 3 & 3 & 3 & - & 1 & 3 & 3 & 3 & 3 & 3 & 2 & 3 & 3 & 3 & 3 & 2 \\
\hline $\begin{array}{l}\text { Tufa barriers } \\
\text { and formations }\end{array}$ & 3 & 1 & 3 & 2 & 3 & 1 & 3 & 1 & 2 & 1 & 3 & 2 & 3 & 1 & 2 & 2 \\
\hline $\begin{array}{l}\text { Grassland pres- } \\
\text { ervation }\end{array}$ & 2 & 2 & 3 & - & 2 & - & 3 & 3 & 2 & 3 & 2 & 2 & 3 & - & 3 & - \\
\hline $\begin{array}{l}\text { Presentation of } \\
\text { the rural area }\end{array}$ & 3 & 1 & 3 & 2 & 2 & 1 & 2 & 2 & 3 & - & 3 & 1 & 3 & 1 & 3 & 2 \\
\hline
\end{tabular}

9 Relevance: 1) the goal is irrelevant; 2) the goal is partially-relevant; 3 ) the goal is relevant; Level of successful achievement: 1) the goal was not achieved; 2) the goal was partially-achieved; 3) the goal was achieved. 


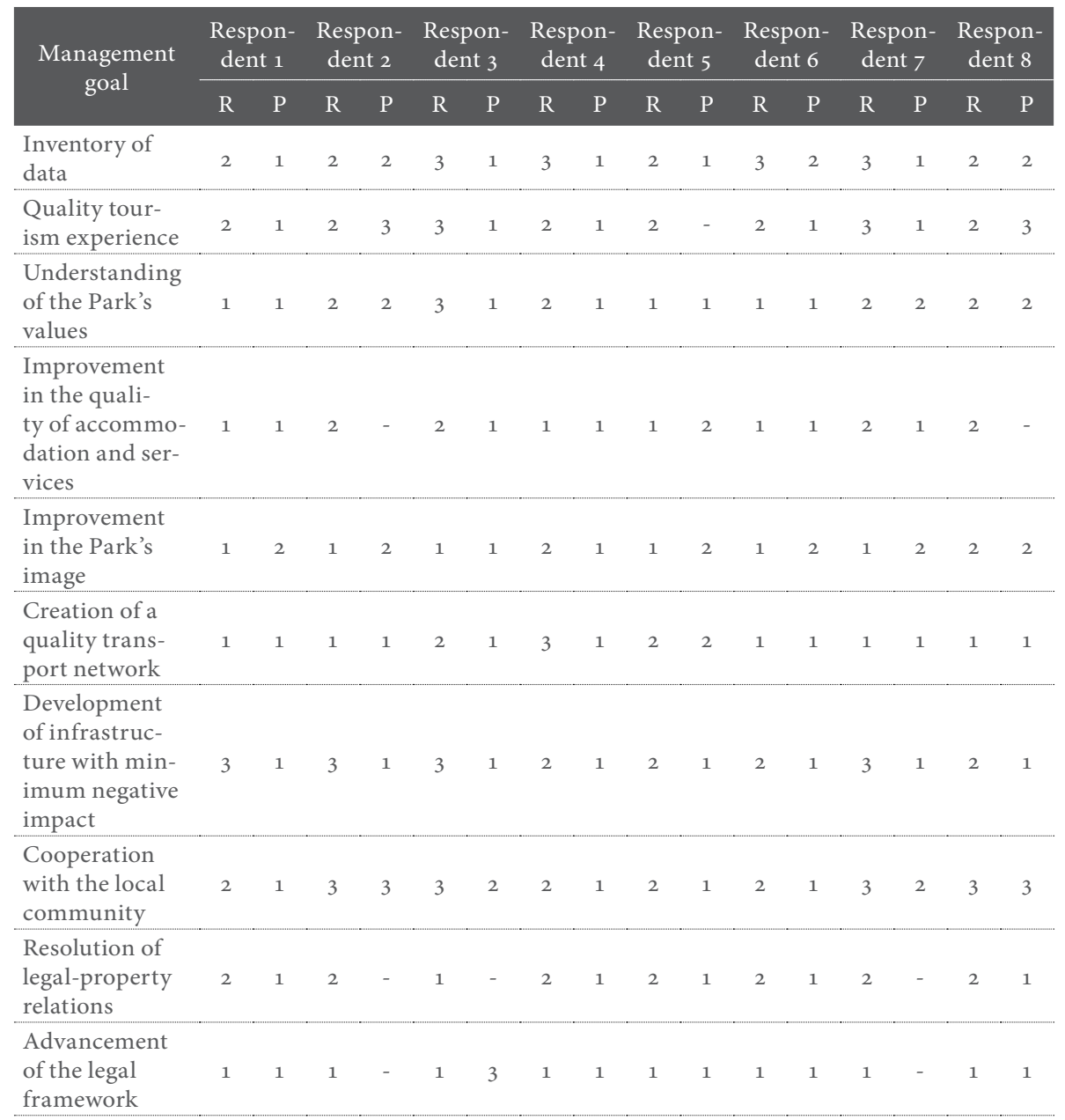


Tab. 3 Scores of relevance and level of connection to goals of prior management plans for management goals in the proposed plan for the period of 2019 to 2028 (R-relevance, P-level of relation to prior goals) ${ }^{\text {I0 }}$ in Proposed Management Plan for Plitvice Lakes National Park, 2019-2028

\begin{tabular}{|c|c|c|c|c|c|c|c|c|c|c|c|c|c|c|c|c|}
\hline \multirow{2}{*}{$\begin{array}{l}\text { Management } \\
\text { goals }\end{array}$} & \multicolumn{2}{|c|}{$\begin{array}{l}\text { Respon- } \\
\text { dent } 1\end{array}$} & \multicolumn{2}{|c|}{$\begin{array}{l}\text { Respon- } \\
\text { dent } 2\end{array}$} & \multicolumn{2}{|c|}{$\begin{array}{l}\text { Respon- } \\
\text { dent } 3\end{array}$} & \multicolumn{2}{|c|}{$\begin{array}{c}\text { Respon- } \\
\text { dent } 4\end{array}$} & \multicolumn{2}{|c|}{$\begin{array}{l}\text { Respon- } \\
\text { dent } 5 \\
\end{array}$} & \multicolumn{2}{|c|}{$\begin{array}{c}\text { Respon- } \\
\text { dent } 6\end{array}$} & \multicolumn{2}{|c|}{$\begin{array}{c}\text { Respon- } \\
\text { dent } 7\end{array}$} & \multicolumn{2}{|c|}{$\begin{array}{l}\text { Respon- } \\
\text { dent } 8\end{array}$} \\
\hline & $\mathrm{R}$ & $\mathrm{P}$ & $\mathrm{R}$ & $\mathrm{P}$ & $\mathrm{R}$ & $\mathrm{P}$ & $\mathrm{R}$ & $\mathrm{P}$ & $\mathrm{R}$ & $\mathrm{P}$ & $\mathrm{R}$ & $\mathrm{P}$ & $\mathrm{R}$ & $\mathrm{P}$ & $\mathrm{R}$ & $\mathrm{P}$ \\
\hline $\begin{array}{l}\text { Preservation of } \\
\text { aquatic ecosys- } \\
\text { tems }\end{array}$ & 3 & 1 & 3 & - & 3 & 1 & 3 & 1 & 3 & 1 & - & 1 & 2 & 1 & 2 & 2 \\
\hline $\begin{array}{l}\text { Preservation of } \\
\text { forest ecosys- } \\
\text { tems }\end{array}$ & 3 & 2 & 3 & - & 3 & 2 & 3 & 2 & 3 & - & 3 & 2 & 3 & 2 & 3 & 2 \\
\hline $\begin{array}{l}\text { Preservation of } \\
\text { grasslands }\end{array}$ & 2 & 2 & 2 & 2 & 2 & 1 & 3 & 2 & 2 & 2 & 2 & 2 & 2 & 1 & 2 & 2 \\
\hline $\begin{array}{l}\text { Preservation of } \\
\text { karst }\end{array}$ & 3 & 1 & 3 & 1 & 3 & 2 & 3 & 1 & 3 & 1 & 3 & 1 & 3 & - & 3 & 1 \\
\hline $\begin{array}{l}\text { Tangible cultur- } \\
\text { al heritage }\end{array}$ & 3 & 1 & 3 & 1 & 1 & 2 & 3 & 1 & 3 & 1 & 3 & 1 & 2 & - & 3 & 1 \\
\hline $\begin{array}{l}\text { Intangible cul- } \\
\text { tural heritage }\end{array}$ & 3 & 1 & 3 & 1 & 3 & 1 & 2 & 3 & - & - & 3 & 2 & - & -- & 3 & 1 \\
\hline $\begin{array}{l}\text { Cultural land- } \\
\text { scape }\end{array}$ & 3 & 1 & 3 & 1 & 3 & 2 & 3 & 1 & - & - & 3 & 1 & - & - & 3 & 1 \\
\hline $\begin{array}{l}\text { Visitation sys- } \\
\text { tem }\end{array}$ & 3 & 2 & 3 & 1 & 3 & 3 & 3 & 2 & 3 & 2 & 3 & 1 & 3 & 2 & 2 & 2 \\
\hline $\begin{array}{l}\text { Hospitality and } \\
\text { commerce }\end{array}$ & 3 & 1 & 3 & 1 & 3 & 1 & 3 & 1 & 3 & 1 & 3 & 1 & 3 & 1 & 3 & 1 \\
\hline $\begin{array}{l}\text { Interpretation } \\
\text { and education }\end{array}$ & 2 & 2 & 3 & 3 & 2 & 2 & 2 & 3 & 3 & 1 & 1 & 3 & 2 & 2 & 2 & 1 \\
\hline Marketing & 1 & 3 & 1 & 3 & 1 & 3 & 2 & 3 & 1 & 3 & 3 & - & 1 & 3 & 1 & 3 \\
\hline $\begin{array}{l}\text { Revitalisation } \\
\text { of agricultural } \\
\text { production }\end{array}$ & 2 & 2 & 3 & 2 & 1 & 2 & 2 & 2 & 2 & 1 & 2 & 2 & 2 & 3 & 2 & 2 \\
\hline $\begin{array}{l}\text { Development } \\
\text { and harmonisa- } \\
\text { tion of the ecot- } \\
\text { ourism supply }\end{array}$ & 3 & 1 & 3 & 1 & 3 & 2 & 3 & 1 & 3 & 1 & 2 & 1 & 3 & 2 & 3 & 1 \\
\hline $\begin{array}{l}\text { Ensuring an ad- } \\
\text { equate legal and } \\
\text { planning frame- } \\
\text { work needed for } \\
\text { management }\end{array}$ & 1 & 1 & - & 1 & 1 & 1 & - & 1 & 2 & 1 & 1 & 2 & 3 & 1 & 1 & 1 \\
\hline
\end{tabular}

Relevance: 1) the goal is irrelevant; 2) the goal is partially-relevant; 3) the goal is relevant; Level of relation to previous goals: 1 ) the goal is not related; 2) the goal is partially-related; 3) the goal is related. 


\begin{tabular}{|c|c|c|c|c|c|c|c|c|c|c|c|c|c|c|c|c|}
\hline \multirow{2}{*}{$\begin{array}{l}\text { Management } \\
\text { goals }\end{array}$} & \multicolumn{2}{|c|}{$\begin{array}{l}\text { Respon- } \\
\text { dent } 1\end{array}$} & \multicolumn{2}{|c|}{$\begin{array}{l}\text { Respon- } \\
\text { dent } 2\end{array}$} & \multicolumn{2}{|c|}{$\begin{array}{l}\text { Respon- } \\
\text { dent } 3\end{array}$} & \multicolumn{2}{|c|}{$\begin{array}{l}\text { Respon- } \\
\text { dent } 4\end{array}$} & \multicolumn{2}{|c|}{$\begin{array}{l}\text { Respon- } \\
\text { dent } 5\end{array}$} & \multicolumn{2}{|c|}{$\begin{array}{l}\text { Respon- } \\
\text { dent } 6\end{array}$} & \multicolumn{2}{|c|}{$\begin{array}{l}\text { Respon- } \\
\text { dent } 7\end{array}$} & \multicolumn{2}{|c|}{$\begin{array}{l}\text { Respon- } \\
\text { dent } 8\end{array}$} \\
\hline & $\mathrm{R}$ & $\mathrm{P}$ & $\mathrm{R}$ & $\mathrm{P}$ & $\mathrm{R}$ & $\mathrm{P}$ & $\mathrm{R}$ & $\mathrm{P}$ & $\mathrm{R}$ & $\mathrm{P}$ & $\mathrm{R}$ & $\mathrm{P}$ & $\mathrm{R}$ & $P$ & $\mathrm{R}$ & $\mathrm{P}$ \\
\hline $\begin{array}{l}\text { Development of } \\
\text { institutional \& } \\
\text { human capaci- } \\
\text { ty and compe- } \\
\text { tence }\end{array}$ & 1 & 2 & - & 2 & 1 & 2 & - & 2 & 2 & 2 & 1 & 2 & 1 & 2 & 1 & 2 \\
\hline $\begin{array}{l}\text { Management } \\
\text { of property and } \\
\text { infrastructure }\end{array}$ & 3 & 2 & - & 2 & 3 & 2 & - & 2 & 3 & 2 & 3 & 2 & 1 & 2 & 1 & 2 \\
\hline
\end{tabular}

In the case of the new management plan, ten goals were deemed to be relevant, three to be partially-relevant, and three to be irrelevant for the Park's management. The goals that were deemed to be irrelevant predominantly related to resource organisation. The respondents were nearly unanimous regarding the improvements, in terms of better-stated goals/subthemes, in the new plan over the former plans, but they agreed that the new goals were rather weakly-linked to the goals of previous management periods-this is not necessarily a bad thing, as one respondent put it: 'the old plan(s) should be filed away and forgotten, only to be dusted off and displayed as an example of what not to do'.

It is indicative that in the case of both plans, priority in terms of relevance was given to the goals aimed at protecting (preserving) the environment, then to protecting cultural heritage and landscapes, and then to goals aimed at strengthening the local community and ecotourism supply. Not even the respondents from economic sciences gave high priority to goals that were oriented towards tourism, hospitality, and marketing. The respondents stressed that the emphasis of such goals, in terms of sustainable management of the Park, was 'the wrong approach, and was not oriented toward the primary goals underlying the founding of the Park'.

One respondent, however, highlighted one of the dangers of the new plan that could lead to poor and improper implementation: 'each measure has a series of activity indicators, however, it is worrisome that the majority of them require the engagement of external contractors, which would add cost and complication, as well as the all-important question of which external contractors should be selected and how'. Moreover, one of the respondents stressed that individual goals and their indicators were determined for a period of ten years, i.e. for the intended duration of the plan, but the sequence in the formulation of the goals is not clearly-defined-only the du- 
ration of lower-level activities is determined-nor is there a timeframe for their implementation. This opens the possibility for a given activity to be delayed or otherwise insufficiently pursued, which could result in its ultimately unsuccessful implementation.

In summation, the dominant attitude was that it is certainly better to have a plan than to not have one, but the fact that the proposed plan will be adopted late would, in and of itself, be a detriment for its quality implementation. Additionally, the new plan still largely treats the goals of environmental, social, economic, and political sustainability as equally-important in an area where this absolutely cannot be the case.

\section{Opportunities for improving management policy}

In regard to the identified management problems, it should be emphasised that contemporary models of management often highlight the need to include different "additional" aspects in the management of protected areas (Newsome et al., 2013). The most frequent integration method is to include the local community, and the integration of socio-cultural sustainability with environmental sustainability for protected areas in order to attain better results in both segments. The second form of integration is to include the surrounding area in the management of the protected area, where one model is used for the entire area and the surrounding area serves as a buffer zone, protecting the core of the protected area from negative influences, while the surrounding rural area benefits from the opportunities offered by protected area status in terms of tourism development and serves as a "service area" for the Park (Leusche et al., 2013).

Zoning based on protection characteristics is carried out in the scope of management plans, i.e. the acceptable level of protection and activities (tourism and residence) for a given area is precisely determined-this is particularly the case in Europe. There are usually pre-existing areas that are used for tourism or housing, regardless of this isolating zoning, which limit the developmental aspects of the space. At the same time, the surrounding region perceives the protected area as a limitation on development, without which it could have a totally different system of management or even development. Therefore, protection and development must be integrated, which is best done by managing the entire area, in which communication between protection and development stakeholders is ensured and cooperation is heartily encouraged. As with the dimension of environmental sustainability, which is monitored as a part of protection, dimen- 
sions of economic and socio-cultural or demographic sustainability must be established.

The aforementioned related dimensions would also have their own specific sets of developmental goals and systems of oversight and assessment. Accordingly, via solutions for individual impact factors and specific impacts in a given protected area, an integrated management model can be created that summarises the best practices and specific management needs, i.e. management goals, activities, monitoring, and (re)evaluation.

Integration is also understood to include integral management of natural and cultural heritage, which defines evaluation, research, inventorying, monitoring, protection measures, interpretation and promotion, and communication and reporting. Whereby, it is vitally important to include all natural and cultural heritage elements (e.g. geological, geomorphological, climatical, hydrological, biological, ethnological, archaeological, and anthropological elements). Furthermore, as an additional element of integral management, the importance of connecting protected areas with neighbouring areas on the regional level (or the international level if the area in question lies along a state's border) should be highlighted. In this way, complete management of a given area is enabled, in terms of both protection and developmental measures.

Initiatives to establish indicators on the global, national, and local levels indicate that they are necessary preconditions for sustainable development, materialisation, measurement, and evaluation of components of the environment, so that the concept of sustainable development would not simply become a general definition. It should be stressed that environmental protection and tourism cannot successfully coexist in an integral management system that is not based on the following two principles: first, the principle of meritocracy of different professions and experts; and second, the principle of continuous improvement of management systems and their oversight. Therefore, further research of all spatial components as an integral line, in which the protected area is only one component, is needed.

\section{Conclusion}

Development of Plitvice Lakes National Park should be regarded in the context of development that has unfolded over the past 150 years (with several short periods of discontinuity), 70 of which have been directed by formal management of some kind. Development throughout the entire timeline has dominantly been dependent on tourism demand and four fundamen- 
tal phases of management have been established, based on the research underlying the chapter:

1. the phase of informal management (1883-1948);

2. the phase of management based on spatial plans (1949-1989);

3. the wartime phase-lack of a fundamental management and decision-making body (1990-2002); and

4. the phase of planned management documents (2003-time of writing).

Despite the largely consistent management presence and actions, it should be stressed that fundamental management problems have been identified: functional overburdening; threats to hydro-geological biotopes; and negative demographic processes in and around the Park. It is discouraging that the recent management phase had no answers to these three fundamental problems, despite the emphasis that was placed on preserving hydro-geological environmental biotopes-which was totally ignored in the second and third phases.

With regard to the fact that management of protected areas is a cyclical process, within the framework of which pre-arranged activities are undertaken to achieve specific goals, it is extremely important to observe how this process unfolded in previous periods, as well as how it is unfolding in current developmental processes. This process and efficiency assessments, based on interviews with respondents, show that the majority of goals were insufficiently relevant and unsuccessfully carried out, which is extremely important in terms of efficient management. The respondents were largely of the opinion that while it is better to have a plan that to not have one, the current plan is flawed in that it treats environmental, social, economic, and political sustainability goals as equally-important in an area where this (by definition) cannot be the case.

Finally, integration of protection and development via management of an entire area would ensure better communication and cooperation among various stakeholders. Additionally, dimensions other than that of a sustainable environment should be taken into account, e.g. economic and socio-cultural/demographic sustainability, in order to properly manage the development of a given area. The aforementioned integral model, which would enable a certain amount of management autonomy for social issues, is necessary in terms of strengthening the integration of the environment and the community as two parts of a single ecosystem. 


\section{References}

Barešić, J., 2009: Primjena izotopnih i geokemijskih metoda u praćenju globalnih i lokalnih promjena u ekološkom sustavu Plitvičkih jezera, Doctoral Thesis, University of Zagreb, Faculty of Science, Zagreb.

Bonnaci, O., 2013: Zabrinjavajući hidrološki trendovi na slivu Plitvičkih jezera - dodatak, Hrvatske vode 21 (84), 137-146.

Canteiro, M., Córdova Tapia, F., Brazeiro, A., 2018: Tourism impact assessment: A tool to evaluate the environmental impacts of touristic activities in Natural Protected Areas, Tourism Management Perspectives 28, 220227, DOI: 10.1016/j.tmp.2018.09.007.

Fuller, C., Ondei, S., Brook, W. B., Buettel, C. J., 2019: First, do no harm: A systematic review of deforestation spillovers from protected areas, Global Ecology and Conservation 18, DOI: 10.1016/j.gecco.2019.eoo591.

Gaston, K. J., Charman, K., Jackson, S. F., Armsworth, P. R., Bonn, A., 2006: The ecological effectiveness of protected areas: the United Kingdom, Biological Conservation 132 (1), 76-87, DOI: 10.1016/j.biocon.2006.03.013.

Harding, R., 2006: Ecologically sustainable development: origins, implementation and challenges, Desalination 187 (1-3), 229-239, DOI: 10.1016/j. desal.2005.04.082.

Ivanuš, M., 2010: Vrednovanje turističke izgradnje na području Plitvičkih jezera, Prostor 18 (1), 123-135.

Lausche B., Farrier, D., Verschuuren, J., La Vina, A., Trouwborst, A., Born, C., Aug, L., 2013: The Legal Aspects of Connectivity Conservation Law: A Concept Paper, IUCN, Gland.

Lukić, A., 2012: Mozaik izvan grada - tipologija ruralnih i urbaniziranih naselja Hrvatske, Meridijani, Samobor.

Marković, I., 2015: Problemi i mogućnosti održivoga upravljanja zaštićenim prirodnim područjima: primjer Nacionalnoga parka Plitvička jezera, Doctoral Thesis, University of Zagreb, Faculty of Science, Zagreb.

Marković Vukadin, I, Franjković, D., 2019: Turizam i ugostiteljstvo, razvojni izazovi i potencijali nacionalnog parka Plitvička jezera, in: 70 godina Nacionalnog parka Plitvička jezera (ed. Kovačević, T.), Javna ustanova "Nacionalni park Plitvička jezera", Plitvička jezera.

Martinić, I., 2010: Upravljanje zaštićenim područjima prirode - planiranje, razvoj i održivost, Šumarski fakultet, Sveučilište u Zagrebu, Zagreb.

Ministry of Environment and Energy of the Republic of Croatia, Croatian Agency for the Environment and Nature, 2018: Guidelines for the man- 
agement of protected areas and/or ecological network areas, Zagreb, http:// www.haop.hr/sites/default/files/uploads/dokumenti/o4_zasticena/smjernice/Smjernice_za_planiranje_upravljanja_MZOE_HAOP_2018.pdf

Mora, C., Sale, P. F., 2011: Ongoing global biodiversity loss and the need to move beyond protected areas: a review of the technical and practical shortcomings of protected areas on land and sea, Marine Ecology Progress Series 434, 251-266, DOI: 10.3354/mepso9214.

Newsome, D, Moore S. A., Dowling R. K., 2013: Natural Area Tourism, Ecology, Impacts and Management, Channel View Publications, Bristol - Buffalo - Toronto.

Opačić, V. T., Lukić, A., Fuerst-Bjeliš, B., 2005: Sustainable development of recreation and tourism in the protected areas of Croatia: issues and indicators, Problemi na geografijata 3-4, 209-223.

Pejnović, D., 1992: Razvoj naseljenosti i promjene narodosnog sastava u Plitvičkoj regiji, Geografski glasnik 54, 75-97.

Petrić, K., 2012: Pejsažna i prostorno-organizacijska obilježja tradicijskih naselja na području Nacionalnog parka Plitvička jezera, Master Thesis, University of Zagreb, Faculty of Architecture, Zagreb.

Petrić, L., 2008. Kako turizam razvijati na održiv način u zaštićenim obalnim prostorima? Primjer „Park prirode Biokovo”, Acta Turistica Nova 2, 5-24.

Petrik, M., 1958: Prinosi hidrologiji Plitvica, in: Nacionalni park Plitvička jezera (ed. Šafar, J.), 49-173.

Pevalek, I., 1924: La travertine phytogene des lacs de Plitvice, in: Actes $d u$ I Congres des etnographes et geographes a Prague, 207-208.

Pevalek, I., 1935: Der Travertin und die Plitvicer Seen, Verh d. Internat. Vereinig. F. Limnol, 165-181.

Pevalek, I., 1938: Biodinamika Plitvičkih jezera i njena zaštita, Zaštita prirode $1,40-61$.

Pribičević, B., Medak, D., Đapo, A., 2011: Geodetsko-hidrografska istraživanja na području NP Plitvička jezera. in: Znanstveno-stručni skup Nacionalnog parka Plitvička jezera (eds. Šutić, B, Dujmović, A,), Plitvička jezera: Javna ustanova „Nacionalni park Plitvička jezera”, 68-81.

Radeljak, P., Pejnović, D., 2008: Utjecaj turizma na održivi razvoj funkcionalne regije nacionalnog parka Krka, Godišnjak Titius 1, 329-361.

Sremac, J., Božičević, S., Marković, I., 2011: Plitvice Lakes National Park (central Croatia) - more than 50 years of continuous monitoring of natural and human influence, European Geologist 34 (1), 2-16. 
Stilinović, B., Božičević, S., 1998: The Plitvice Lakes. A natural phenomena in the middle of the Dinaridic Karst in Croatia, European Water Management 1 (1), 15-24.

Šegulja, N., 2005: Vegetacija travnjaka, cretišta i močvarnih staništa Nacionalnog parka Plitvička jezera, Natura Croatica 14 (suppl. 2), 1-194.

Vidaković, P., 1997: Nacionalni parkovi u svijetu, Fond za stipendirane mladih za zaštitu prirode i turizam, Zagreb.

WWF, 2007: Management Effectiveness Tracking Tool, WWF, Gland.

\section{Sources}

Croatian Bureau of Statistics (CBS), 1994: Census of population, households and dwellings in 1991: Population by sex and age, by settlements, www.dzs. hr (12. 09. 2020)

Croatian Bureau of Statistics (CBS), 2003: Census of population, households and dwellings in 2001: Population by sex and age, by settlements, www.dzs. hr (12.09. 2020)

Croatian Bureau of Statistics (CBS), 2013: Census of population, households and dwellings in 2011: Population by sex and age, by settlements, www.dzs.hr (12. 09. 2020)

eVisitor, 2019: Number of overnights in settlements in Croatia, https://www. evisitor.hr/eVisitor/hr-HR/ (20. 06. 2019)

Official Plitivce Lakes Tourist Board, 2014: Internal data.

Plitvice Lakes National Park, 2007: Management Plan, Arcode, Zagreb.

Plitvice Lakes National Park, 2019: Internal data.

Plitvice Lakes National Park, 2019: Proposed Management Plan 2019-2028, https://np-plitvicka-jezera.hr/wp-content/uploads/2018/12/Nacrt-Planupravljanja-NPPJ-2019-2018.pdf?x92898 (13. 07. 2019)

State Geodetic Administration of the Republic of Croatia (SGA), 2019: Central registry of spatial units in the Republic of Croatia (GIS shapefiles), Zagreb. 



\title{
Chapter II
}

Tourism development and green horizons in protected areas of Croatia and Slovenia: synthesis and perspectives

\author{
Miha Koderman, Vuk Tvrtko Opačić, Izidora Marković Vukadin
}

\section{Abstract}

This chapter discusses different management approaches and recommendations for administration of protected areas, where tourism is recognised as one of the most important management challenges-depending on the situation, it can be either a curse or a blessing. Therefore, the goal of this chapter is to compare methods of management of protected areas in Croatia and Slovenia, with an emphasis on tourism. The systems of administering protected areas in both countries show some similarities, but also have major differences. In Slovenia, the system is relatively decentralised, especially for protected areas that are of a lower category of protection. This is the result of a bottom-up approach. In Croatia, the top-down approach, mainly characterised by centralised management, prevails-especially in the case of management of national parks and nature parks. Differences in management approaches influence the level to which a given protected area is included in the tourism supply, which is consequentially reflected in forms of tourism as well as differential spatial influences.

Key words: protected area, management approaches, tourism development, Croatia, Slovenia 


\section{Introduction}

The need for new space for new development opportunities is consequentially reflected in increasingly expressed problems on all levels of spatial development (Faber et al., 1987). The result of this has been an intense increase in the number of protected nature areas over the last 20 years (UNEPWCMC and IUCN, 2016), as well as increasing efforts to efficiently protect protected areas. This highlights the need to determine and resolve problems with existing management models in order to find the most appropriate model for each individual protected area. The global network of parks is currently a key option for maintaining and improving conservation of biodiversity and the environment as a whole (Timko and Innes, 2009).

Numerous authors have highlighted planning and managing the environment as a means of achieving a sustainable environment and sustainable world (Ogrin, 1999; Boetequilha and Ahern, 2002), not simply for its physical presence, but for its metaphysical connotations, as well as the ability to plan and protect landscapes in keeping with social factors (Butula, 2003). Accordingly, the question emerges of whether tourism in protected areas is an opportunity or a challenge (or both), when contemporary trends in global tourism indicate conflicting interests for protected areas (Guimarães et al., 2018). This affects the direction of development for areas that are generally unevenly-developed and generate significant economic benefit (Dudley et al., 2008). Tourism, as opposed to other economic sectors, is (theoretically) interested in maintaining protected areas in order to continue using and developing them for material gain in the long term (Ružić, 2011).

\section{Approaches to the management of protected areas}

The founding of the first national parks naturally sparked ruminations on how they might be managed (Marinović-Uzelac, 2001). In the era when the first protected areas were largely managed as individual components of the areas in which they were found, the character of management significantly differed depending on the state and management goals. Today, the emphasis is decidedly on the concept and quality of management of protected areas (Martinić, 2010). The need for active management of protected areas has become clear with time, after experiences showed that a declaration of protected status alone was not enough to actually protect an area (so-called "paper parks") (Dudley et al., 1999). 
In order to successfully protect an area, influence over the activities taking place within it is necessary. Therefore, the management of protected areas depends on the management of economic (and other) activities taking place therein, whereby activities should either be restricted or encouraged, depending on the needs of the space. There is significant emphasis in management on protecting natural diversity and cultural heritage, education and recreation, and strengthening local communities.

Management of protected areas is a cyclical process, whereby goals are reached by carrying out pre-arranged activities within a set framework (Dudley et al., 1999). The aforementioned process includes assessment of the status of a given area, and defining management goals and necessary planning activities to achieve them, which are then carried out with simultaneous oversight and efficiency assessments - allowing for the adjustment of planning activities as deemed necessary-after which the entire process is repeated (Ministry of Environment and Energy of the Republic of Croatia, 2018). Management goals must present a clear description of that which is meant to be achieved via management. Activities of management are those that should be carried out in order to reach a specific goal or goals. The implementation of goals is understood to include the implementation of planning activities.

Oversight, in this context, refers to two different activities: overseeing the implementation of planning activities (what was done, how, and when); and overseeing the effectiveness thereof (overseeing changes in the status of that which is being protected) (Ministry of Environment and Energy of the Republic of Croatia, 2018). In keeping with the aforementioned, the self-management of protected areas should be (Alexander, 2008):

- $\quad$ based on assumed obligations - in harmony with the reasons underlying a given area's protected status;

- appropriate-adjusted to the specific conditions and needs of a given area, and based on established practices and decision-making methods;

- adaptable - able to adapt activities to changes in management conditions without threatening the underlying status for which the area was given protected status;

- participative-directing how stakeholders are able to actively take part in the management of protected areas with their advice, recommendations, and/or concrete activities; 
- planned-management goals and activities are planned in advance and their implementation takes place according to pre-arranged priorities and plans;

- transparent-open to the public and clearly-defined.

In order to increase the potential of protected areas, administrators and policy makers seek information regarding the strengths and weaknesses of management methods, and the various pressures and threats that protected areas are subjected to (Hockings, 2003). There are many reasons to assess management efficiency. For example, management bodies generally want to improve their performance via flexible management. Local and national governments and agencies generally want to wisely invest in protected areas, taking into account the specific needs of a given protected area and prioritising accordingly. Local communities and NGOs generally want to know that their interests are being taken into account in the planning process for a given area. Other stakeholder demands might also present themselves during the planning process, i.e. for more transparent reporting, good business practices, etc. (Hockings et al., 2006). Assessment of planning (or aspects and goals of planning) consists of an analysis of all relevant information for a given area, forming the basis for the definition of management goals and activities.

\section{Management of tourism in protected areas of Croatia and Slovenia-similarities and differences}

Although tourism can have many beneficial effects on protected areas, management of tourism often presents a considerable challenge. In order to ascertain how to best administer tourism in protected areas, especially in national parks, the main trends in tourism demand and supply must be determined. According to Eagles (2007), park visitation will continue to increase in the future and tourism in national parks will lead to increased public participation and collaboration, while increasing education levels in society will lead to increased sophistication in park administration and park services.

Other important trends can be identified, such as the increasing share of elderly population, which has a significant influence on the demand of activities, settings, and experiences in protected areas, as well as the increasing availability and accessibility of information technology, which profoundly influences park visitation. Continuous growth of the number of 
protected areas, especially national parks, impacts the capability of many park administration institutions, and finally, global climate change will affect many protected areas and the tourism taking place in them in unforeseeable ways.

One of the most important questions regarding the management of protected areas (as well as tourism) is financing. As Conner $(2007,210)$ argues, 'protected areas are financed and supported by governments because they are public goods, that is, they are non-rival and not-excludable'. An equally-important reason for financing protected areas with public funds lies in the fact that they represent natural value that has been recognised and protected by the state for future generations, as natural heritage and part of the local, regional, and/or national identity.

On the global level, there has been a noticeable trend of reduced financing for protected areas from state budgets (as well as from other public sources), with a parallel increase in entrance fees, educational and recreational programmes, and other activities. This means that the most attractive protected areas are increasingly transforming into typical tourism sights, and in some cases full-fledged tourism destinations, forcing their primary role-nature protection-to play second fiddle. In such cases, the management of protected areas closely resembles the management of business entities.

This is a real and present problem for successful nature protection, which has led to paradoxical situations of commercialisation of protected areas in circumstances when mass tourism has threatened their fundamental function, i.e. the reason for which the area was categorised as protected: nature preservation. On the other hand, with sustainable tourism, revenues support nature protection activities and can be recognised as a decided benefit for the maintanence of protected areas. Another positive aspect of sustainable tourism development in protected areas is the prevention of other, more environmentally invasive activities.

Less-attractive and/or less well-known protected areas have fewer tourist visits, limiting the scope of tourism services and the financial effect of entrance fees. In most cases nature protection is not in question, however, under conditions of reduced public financing and tourism income, nature protection as a fundamental function can come under threat.

The aforementioned management challenges are also visible in examples of management of protected areas in Croatia and Slovenia. This is clear in the context of tourism valorisation and administration of speleological 
formations. Bočić et al. (2006, 20), came to the following conclusion after researching administration models and tourism valorisation: 'although the majority of the show caves in Croatia are protected by the category of geomorphological monument of nature, their tourism valorization primarily depends on the way of management. Namely, if a public institution runs a cave (e.g. Nature Park or National Park), the protection component is more prominent, ..., as well as the fact that the profit from the cave does not make the basic element of the public institutions profit structure. On the other hand, if a private concessionaire manages a show cave, the business orientation towards tourism is more marked. Consequently, in these cases the connection with local economy is more prominent, just as the significance of the phenomenon within the tourist destinations'.

Different administrative approaches can also be seen in the example of Postojna Cave and Škocjan Caves, the two most-attractive (to tourists) speleological formations in Slovenia. Although both areas enjoy a large number of visitors, Postojna Cave and its surroundings have developed as a typical mass tourism destination, while conservation and a "softer" development approach with positive efforts on the part of the local community characterises the management of Škocjan Caves (Jurinčič and Balažič, 2011).

The systems of management of protected areas in Croatia and Slovenia show some similarities, but also meaningful differences. In Slovenia, the system is relatively decentralised (Groznik Zeiler, 2011), due to a bottom-up approach. Namely, apart from Triglav National Park (the most significant protected area in the state), public institutions founded and financed by the state administer all regional parks, landscape parks, and one of the 56 nature reserves.

All other protected areas lack a public institution tasked with their administration. Local communities (LAU 2) can, if interested, administer such areas via concession. In such lower-rank protected areas (of interest to tourists), tourism development is most often not integrated into a unified tourism supply along with other protected areas. An additional problem in this sort of management system is the lack of clearly-defined institutional responsibilities in terms of governance, which can also be seen in the lack of management plans.

This can lead to situations where the status of protected area is simply a "paper shield" (e.g. in Zajčja Dobrava, Udin Boršt, and Šturmovci 
landscape parks). Many authors have warned that without institutionalised management it is difficult to imagine balanced future development of protected areas that must simultaneously juggle nature protection, tourism and recreation, education, and other functions (Hribar et al, 2011).

There are, however, advantages to the existing type of management of lower-rank protected areas (in Slovenia) in terms of creating opportunities for stronger implementation of participative approaches, involving all shareholders in the local community with the goal of integrating a given protected area into the spatial and social development of the wider area in which it is located. On this sort of basis, specific forms of sustainable tourism within a given protected area and its surroundings can emerge, such as nature-based tourism, ecotourism, rural tourism, etc. Thereby, the protected area in question becomes one of a number of tourist attractions in the wider area, creating opportunities for tourism valorisation and the development of other attractions.

In the system of management of protected areas in Croatia, the approach is primarily centralized, i.e. top-down, especially in terms of management of national parks and nature parks-the most visited types of protected areas. In protected areas with lower degrees of protection, a bottom-up approach in terms of establishments and management is also implemented.

An example of the top-down management approach is the PARCS Project (Strengthening the Institutional and Financial Sustainability of the National System of Protected Areas in the Republic of Croatia), which was implemented from 2014 to 2017 by the Ministry of Environmental Protection and Energy of the Republic of Croatia and the UN Development Programme (UNDP), in partnership with public institutions that administer national and nature parks and the Croatian Agency for the Environment and Nature. The project was organised into two components: 1) reformation of the institutional framework in order to strengthen management efficiency of national protected areas; and 2) improving financial sustainability of the network of national protected areas (Ministry of Environment and Energy of the Republic of Croatia, 2017). The aforementioned project enabled the communal presentation and branding of Croatian national and nature parks for the tourism market (Fig. 1), which resulted in an increase in the number of visitors over the last few years. 

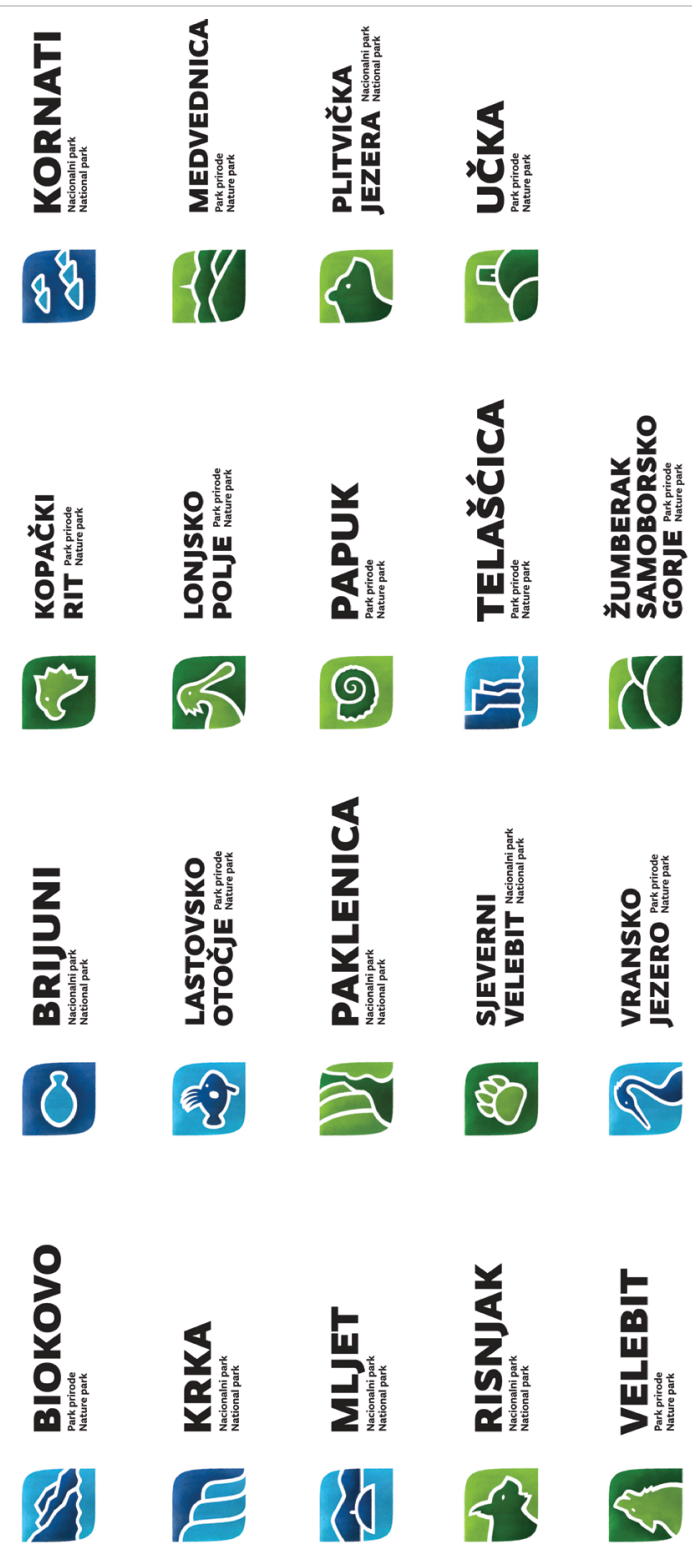

Fig. I Logos for Croatian national and nature parks. The green logos represent continental protected areas, and blue logos represent coastal and island protected areas. This is an excellent example of an integrated visual identity for protected areas, designed for tourism marketing.

Source: Ministry of Environment and Energy of the Republic of Croatia, 2019 
In this way, some Croatian nature parks (e.g. Papuk, ŽumberakSamoborsko Gorje, Medvednica) and national parks (e.g. Risnjak and Northern Velebit), which would be less-visible and less visited by tourists (thus generating less income) without significant marketing efforts (web pages, mobile applications, etc.), have been promoted. The number of tourist visits is rising every year in these areas, even though they are still dominantly characterised by educational and recreational activities.

The remaining protected areas are administered by competent public institutions on the county (regional) level, which are present in and financed by each of Croatia's 21 counties, and in few cases by cities, towns, municipalities, and special public institutions. Although the exact manner of management of protected nature areas varies slightly from county to county, it can be seen that the presence of an administrative body has enabled stronger (communal) promotion and integral administration on the regional level, especially for lesser-known areas of lower protection categories.

Such a system of management of protected areas (in Croatia), from the aspect of tourism, opens perspectives of development of (mass) tourism within protected areas themselves, as well as in less-influential areas outside of a given park's borders. This also carries with it the risk that the most visited national parks could transform into full-fledged tourism destinations.

\section{Conclusion}

Regardless of differences in management, protected areas-foremost national parks and nature parks in Croatia and Slovenia-are experiencing more and more visitors each year. In relation to global trends, it is realistic to expect that the number of visitors to these areas will continue to rise, and that the conflict between tourism development imperatives and nature protection imperatives will intensify in and around the most-visited protected areas (e.g. Plitvice Lakes National Park, Krka National Park, Triglav National Park, and Škocjan Caves Regional Park). Therefore, strict measures limiting further construction of residential and tourist accommodation should be enacted, in order to maintain an acceptable balance. Apart from construction, regulation of visitor traffic flows in national and nature parks is needed, as well as incentivising and strengthening public transport over personal automobiles (e.g. buses to Vrata Valley in Triglav National Park). 
Special care should be given to proper distribution of tourism visits, in both spatial and temporal terms. The aforementioned spatial aspect is understood to mean balanced spatial distribution of visitors within a given protected area, in order to reduce pressure on the most attractive locations. The temporal aspect relates to more balanced tourism over longer periods (weeks, months, years), in order to reduce negative seasonal effects arising from higher visitation on weekends and overall during the warmer half of the year-especially during the high season (summer) of tourism. It is of inestimable value to continually and consistently work on improving education and ecological awareness efforts for both visitors and the local community, in order to preserve the most-visited national and nature parks for future generations, and simultaneously contribute to local economies and communities.

Protected areas of lower attractiveness to tourists in both states should be promoted more strongly to the public, not only for the purposes of tourism marketing, but for their value to society (natural and cultural heritage) as well as for the services that they provide to the ecosystem. In the context of tourism development, such areas can play a significant role as relief areas for the most-visited tourism destinations. Less-developed areas can diversify their economic structure and raise the quality of life for their residents by developing a higher-quality rural, eco, and nature-based tourism supply, as well as recreational activities.

Tourism valorisation of protected areas in Croatia and Slovenia has the power to create additional economic, ecological, social, and political value. Namely, a large share of the border area between Croatia and Slovenia is ripe ground for opportunities of cross-border cooperation for nature protection due to homogeneity and similar natural characteristics. The realisation of closer cross-border cooperation could be easily achieved with Croatia's accession to the Schengen Area, which would render tourism-recreational mobility between the two countries much easier. Additionally, stronger links between existing protected areas on both sides of the border, as the basis for a cross-border protected area (e.g. Risnjak in Croatia-Snežnik in Slovenia, Žumberak-Samoborsko Gorje in Croatia-Gorjanci in Slovenia, the north-western part of Hrvatsko Zagorje-Kozjansko in Slovenia), represent suitable opportunities for cooperation for mutual benefit. 


\section{References}

Alexander, M., 2008: Management planning for nature conservation, a theoretical basis and practical guide, Springer Science, Cham.

Bočić, N., Lukić, A., Opačić, V. T., 2006: Management models and development of show caves as a tourist destinations in Croatia, Acta Carsologica 35 (2), 13-21, DOI: 10.3986/ac.v35i2-3.224.

Botequilha Leitão, A., Ahern, J., 2002: Applying landscape ecological concepts and metrics in sustainable landscape planning, Landscape and Urban Planning 59 (2), 65-93, DOI: 10.1016/So169-2046(02)0ooo5-1.

Butula, S., 2003: Planning for sustainable development: the significance of different social interests in landscape, Društvenja istraživanja 12 (3-4), 427-445.

Conner, N., 2007: Economic impacts of parks on surrounding communities: findings from New South Wales, in: Tourism and protected areas: benefits beyond boundaries (eds. Bushell, R., Eagles, P.), CAB International, Oxfordshire - Cambridge, 210-230.

Dudley, N., Gujja, B., Jackson., B., Jeanrenaud, J. P., Oviedo, G., Phillips, A., Rosabel, P., Stolton, S., Wells, S., 1999: Challenges for protected areas in the 21st century, in: Partnerships for protection: new strategies for planning (eds. Stolton, S., Dudley, N.), Routledge, London, 3-12.

Eagles, P. F. J., 2007: Globel trends affecting tourism in protected areas, in: Tourism and protected areas: benefits beyond boundaries (eds. Bushell, R., Eagles, P.), CAB International, Oxfordshire - Cambridge, 27-43.

Faber, M., Niemes, N., Stephan G., 2012: Entropy, environment, and resources, Springer Verlag, Berlin, DOI: 10.1007/978-3-642-97047-4.

Groznik Zeiler, K., 2011: Razvojna vloga zavarovanih območij v Sloveniji, in: Razvoj zavarovanih območij v Sloveniji (eds. Nared, J. et al.), Geografski inštitut Antona Melika ZRC SAZU, Ljubljana, 23-32.

Guimarães, E. S., Sá, A., Gabriel, R., Moreira, H., Guimarães, J. R. S., Bandeira, P. F. R., Silva, J. M. F. L., Soares, R. C., Melo, J. P. P., 2018: Matrix of priorities for the management of visitation impacts on the geosites of Araripe UNESCO Global Geopark (NE Brazil), Geosciences 8 (6), 199, 1-21, DOI: 10.339o/geosciences8060199.

Hockings, M., 2003: Systems for assessing the effectiveness of management in protected areas, BioScience 53 (9), 823-832, DOI: 10.1641/00o6-3568(2003)053[0823:SFATEO]2.0.CO;2. 
Hockings, M., Stolton, S., Leverington, F., Dudley, N., Courrau, J. (eds.), 2006: Evaluating effectiveness - a framework for assessing management effectiveness of protected areas, World Commission on Protected Areas, Amsterdam.

Hribar, M., Šmid Hribar, M., Erhartič, B., 2011: Premislek o razvoju in zavarovanih območjih, in: Razvoj zavarovanih območij v Sloveniji (eds. Nared, J. et al.), Geografski inštitut Antona Melika ZRC SAZU, Ljubljana, 11-21.

Jurinčič, I., Balažič, G., 2011: Determining carrying capacity of the Škocjan Caves Park for the implementation of sustainable visitor management, in: Tourism and quality of life - proceedings (ed. Jere Jakulin, T.), Turistica Fakulteta za turistične študije, Portorož, 205-215.

Marinović-Uzelac, A., 2001: Prostorno planiranje, Dom i svijet, Zagreb.

Martinić, I., 2010: Upravljanje zaštićenim područjima prirode - planiranje, razvoj i održivost, Šumarski fakultet, Sveučilište u Zagrebu, Zagreb.

Ministry of Environment and Energy of the Republic of Croatia, 2017: Projekt PARCS - pregled rezultata, Zagreb.

Ministry of Environment and Energy of the Republic of Croatia, 2019, Zagreb.

Ministry of Environment and Energy of the Republic of Croatia, Croatian Agency for the Environment and Nature, 2018: Guidelines for the management of protected areas and/or ecological network areas, Zagreb, http:// www.haop.hr/sites/default/files/uploads/dokumenti/o4_zasticena/smjernice/Smjernice_za_planiranje_upravljanja_MZOE_HAOP_2018.pdf.

Ogrin, D., 1999: Landscape as a research problem, Agriculture Conspectus Scientificus 64 (4), 239-242.

Ružić, V., 2011: Marketing zaštićenog područja - case study Nacionalni park Plitvička jezera. Zbornik radova Međimurskog veleučilišta u Čakovcu 2 (2), $77-83$.

Timko, J. A., Innes, J. L., 2009: Evaluating ecological integrity in national parks: case studies from Canada and South Africa, Biological Conservation 142 (3), 676-688, DOI: 10.1016/j.biocon.2008.11.022.

UNEP-WCMC and IUCN, 2016: Protected Planet Report 2016, Cambridge - Gland. 


\section{(cc) BY-SA}

\section{Authors}

\section{Valentina Brečko Grubar}

is a teacher (assistant professor) and researcher (research fellow) at the Department of Geography of the Faculty of Humanities at the University of Primorska in Koper, Slovenia. Her main research fields are: hydrology; landscape ecology; environmental geography; and sustainable development. She is the author or co-author over 50 scientific articles, conference contributions, and chapters in monographs. She is an active member of the editorial board of the Geografski vestnik (Geographic Bulletin) professional journal. She teaches different courses in graduate and postgraduate study programmes in the fields of physical geography, the environment, and sustainable development.

\section{Slaven Gašparović}

works as an assistant professor at the Department of Geography of the Faculty of Science at the University of Zagreb. He received his master's degree and $\mathrm{PhD}$ at the same university. His research deals with transportation geography, especially with social aspects of transportation (i.e. transportation disadvantage, transportation-based social exclusion, transportation poverty, transportation of vulnerable groups), as well as interrelations between ICT, social networks, and travel behaviour. He has written 20 scientific papers and participated in 13 scientific conferences. He has participated in several projects (e.g. CH4LLENGE, Sinergi, bilateral projects), and 
has been a member of several COST Actions. He is an editorial board member of the scientific journal Acta Geographica Croatica.

\section{Igor Jurinčič}

is an associate professor at the University of Primorska in the Faculty of Tourism Studies Portorož - Turistica. He is a researcher of tourism geography, spatial planning of tourism, sustainable tourism, and wine tourism. He is the author or co-author of many books and scientific papers. His papers have been published in many scientific reviews, like Tourism, International Journal of Sustainable Development and Planning, Hotel-link, Academica Turistica, Dela, Varstvo narave, Geografski glasnik, and Informatica. He has worked on many Slovenian and international projects with useful outputs for tourism development. He was the chair of the Mediterranean Institute of Tourism Research and the Department of Tourism Destination Management, and also Vice Dean for Research of the Faculty of Tourism Studies Portorož - Turistica of the University of Primorska.

\section{Simon Kerma}

is a geographer and sociologist of culture. He is an assistant professor and a researcher at the University of Primorska in the Faculty of Tourism Studies Turistica. He is the Head of the Department of Cultural Tourism. He is also one of the initial promoters and a collaborator of the Centre of Gastronomy and Wine Culture of the University of Primorska. In his research, he deals with issues in tourism geography, cultural tourism, wine and culinary tourism, sustainable tourism, ecotourism, and tourism development in rural areas. He has been a co-editor of several professional and scientific monographs, as well as co-author of scientific papers published in Academica Turistica, Annales, Geoadria, Geografski vestnik, Region and regionalism, and ZRC $S A Z U$. He has also been an active member of the steering committees of several domestic and international scientific conferences and summer schools.

\section{Miha Koderman}

is a teacher (associate professor) and researcher (senior research fellow) at the Department of Geography of the Faculty of Humanities at the University of Primorska in Koper, Slovenia. His main research fields include tourism and economic geography, as well as geography of migration. $\mathrm{He}$ is the author (or a co-author) of one scientific monograph and over 40 scientific articles, conference contributions, component parts, or chapters in monographs. He has co-edited 4 scientific monographs and is also an active member of the editorial board of the Geografski obzornik (Geographic 
Horizon) professional journal. He has also been a visiting professor at the University of Zagreb, Croatia, in the Department of Geography of the Faculty of Science (2017-2018), and at the Department of Geosciences of the University of Massachusetts Amherst, U.S.A. (2020).

\section{Nataša Kolega}

is a researcher and director at Rubin Portorož, ltd. Her main research fields include coastal geography, remote sensing, especially implementation of lidar and sonar data in coastal geography and geomorphology research, GIS, cartography, and geoinformatics. She is the author (or a co-author) of over 15 scientific articles, conference contributions, component parts or chapters in monographs, and over 12 treatises, preliminary studies, and studies. She was an assistant professor and researcher at the Department of Geography of the Faculty of Humanities at the University of Primorska in Koper, Slovenia (2012-2019), and a GIS manager at Harpha sea, ltd. (2005-2018).

\section{Gregor Kovačič}

is an associate professor and a senior research fellow at the Department of Geography of the Faculty of Humanities at the University of Primorska in Koper, Slovenia. His main research fields are hydrogeography, hydrology, and vulnerability of karst environments, as well as geomorphology and geographical aspects of sustainable development. He is the author of a scientific monograph and 37 research articles, several conference contributions, and 13 research chapters in monographs.

\section{Bojana Lipej}

is a biologist and the coordinator for education of Škocjanski zatok Nature Reserve, which is managed by the non-governmental organisation DOPPSBirdLife Slovenia. Her main fields of work are biology, wetland protection, nature conservation, education, and pollution prevention/protection. She is involved in the management of the protected area as well as in various projects that are closely related to nature protection. She is the co-editor of 1 scientific monograph, the author or co-author of 10 articles and chapters in books, and 3 conference contributions. Her particular interest is to develop and improve educational tools in protected areas with particular emphasis on wetlands.

\section{Lovrenc Lipej}

is a marine biologist and senior researcher, employed at the Marine Biology Station of the National Institute of Biology in Piran, Slovenia. The bulk 
of his work deals with mapping and monitoring marine biodiversity and habitat types in the Slovenian coastal sea. His working methods are related to non-destructive SCUBA sampling techniques such as different types of visual census methods for assessing the coastal fish fauna. In addition, he is working on topics related to the impact of climate change and bioinvasion of marine and coastal biodiversity. He has published more than 120 scientific papers and 12 scientific books. He is also a full professor, holding lectures on different courses such as marine ecology, biotic globalisation in seas and oceans, marine zoology, marine biodiversity, etc. at various Slovenian universities (the University of Primorska, the University of Ljubljana, and the University of Maribor).

\section{Izidora Marković Vukadin}

has been employed at the Institute for Tourism in Zagreb, Croatia since 2009 as a junior researcher and postdoctoral researcher, and from 2017 onward as a research associate. She also lectures at VERN University and Edward Bernays University in Zagreb, Croatia. As an expert in sustainable tourism, she has participated in European projects concerning spatial development of tourism, as well as in a large number of master plans of tourism development on national, regional, and local levels. She has considerable experience in the development of indicators of sustainable tourism for the needs of sustainable tourism in Croatia. She has published 4 chapters in scientific books, 12 papers in scientific journals and proceedings, and participated in more than 10 international conferences. Her research work is focused on sustainable tourism development and management, and the impacts of tourism on protected areas and identity.

\section{Vuk Tvrtko Opačić}

is a full professor at the Department of Geography of the Faculty of Science at the University of Zagreb, where he received his $\mathrm{PhD}$ in 2008 on the topic of "Second homes in littoral Croatia - a geographical perspective". His main research field is tourism geography, especially the following topics: second home development; tourism valorisation of heritage; tourism and recreation in protected areas and urban green spaces; typology of tourism destinations; tourism in regional and local development; and alternative forms of tourism. He is the author or co-author of 1 scientific monograph, 1 university textbook, 35 scientific papers, 2 chapters in scientific monographs, and 1 chapter in a university textbook. He has participated in 27 scientific conferences. He is the editor-in-chief of the Hrvatski geografski glasnik (Croatian Geographical Bulletin) scientific journal. 


\section{Petra Radeljak Kaufmann}

is an associate professor at the Department of Geography of the Faculty of Science at the University of Zagreb. She received her master's degree from the same department in 2007 with the thesis topic of "The Impact of Tourism on Sustainable Development of Krka National Park" and her PhD in 2014 with the dissertation titled "Scenario Method in Spatial Planning: A Case Study of the Southern Croatian Littoral". Her main research interests relate to specific methods and techniques in regional and spatial planning (especially scenario method, Delphi method, and spatial analysis methods) and development challenges of rural and karst areas. She has published 19 scientific papers and participated in 18 scientific conferences. She teaches several courses at the undergraduate, graduate, integrated, and doctoral levels.

\section{Romina Rodela}

is a research fellow at the School of Natural Sciences, Technology and Environmental Studies of Södertörn University, Sweden. She works in the field of environmental governance, and is involved with two research projects focused on participatory methods and tools, with a focus on the ways in which such tools can support knowledge integration, learning, and just outcomes. She has collaborated with practitioners and researchers from diverse disciplines. She is committed to interdisciplinary research seeking to further the understanding of the dynamics of the interrelationship between society and the natural environment.

Ivan Šulc

works at the University of Zagreb in the Department of Geography of the Faculty of Science as a postdoctoral researcher and teaches undergraduate and master courses. He defended his doctoral thesis "Models of Tourism Development in South Dalmatia" in 2016 at the same university. His research interests focus on sustainable tourism, tourism impacts, the relation between tourism and the environment, and geographical information systems. He actively participates in three COST Actions (RESTORE, ENEC and Underground 4 Value) and has collaborated in 13 research and other projects related to tourism, introducing GIS in high school education, and strategical regional planning. He is the secretary of the Hrvatski geografski glasnik scientific journal, a member of the steering committee of the Croatian Geographical Society, and a team leader at the International Geography Olympiad. 



\section{(cc) BY-SA}

\section{Reviews}

\section{Review 1}

The monograph Challenges of Tourism Development in Protected Areas of Croatia and Slovenia addresses the issue of tourism development in protected areas in Slovenia and Croatia. Joint discussion of this issue represents a significant added value, which is important due to the spatial proximity of both countries and numerous connections in the field of tourism, as well as common tradition in the field of nature protection from the time of the common Yugoslav state. The main objective of the monograph was to perform a comparative analysis of the spatial development of tourism in protected areas in Croatia and Slovenia. This topic is particularly relevant because of the increase in tourist visits in both countries in the recent years, which also applies to protected areas. The increase of tourist arrivals results in an increase in environmental burdens, which in the case of escalating negative impacts could question the continued coexistence of tourism and the protective function of protected areas.

The monograph consists of 11 chapters which were contributed by 14 authors from Slovenia and Croatia. The introductory chapter presents the categories of protected areas in both countries and highlights their harmonisation with the categories of the International Union for Conservation of Nature and Natural Resources. It also discusses the main specifics of tourism in protected areas in both countries. The next seven chapters present case studies of individual protected areas. Their selection is varied in terms 
of content, as the areas in question are quite different in their characteristics, which allows us to address various issues that are relevant in connection with protected areas. Another chapter deals with the impact of accessibility on tourist flows in Croatian protected areas, and a similar chapter is intended to address the issue of spatial planning of tourism in protected areas in Slovenia. The concluding chapter offers a synthesis of findings and reflections on protected area management.

Due to the contextual design of the monograph, the latter is expected to find a wide range of readers. The contents discussed are of interest to both researchers and students from different professional fields (especially geography and tourism studies), as well as all those involved in the development of tourism and nature protection in different contexts and at different spatial levels. Tourism development policies have paid considerable attention to sustainable development and protection of the environment and nature recently, and a comparative analysis of these concepts further increases the relevance of the monograph. Tourism development can also have negative effects on the protective function of protected areas, therefore a detailed examination of related issues, addressed in the monograph, is needed in order to gain a better knowledge and understanding about this phonomenon.

The monograph offers an in-depth insight into the issues of tourism in protected areas in both countries. Although various authors from different research fields participated in the preparation of the monograph, it nevertheless works as a whole, as the contents of individual chapters complement each other and successfully discuss the issues from several angles. The specific quality of the monograph is also reflected in transcending national boundaries, and such a transnational perspective also helps to place the presented cases in the broader context of tourism development in protected areas.

Dejan Cigale, $P h D$

Assistant Professor, University of Ljubljana, Faculty of Arts, Department of Geography Ljubljana, Slovenia 


\section{Review 2}

The scientific book Challenges of Tourism Development in Protected Areas of Croatia and Slovenia consists of 11 chapters in the form of individual scientific papers with a total of 14 authors from Croatia and Slovenia. The first and last chapter of the book represent a kind of introduction and conclusion of the book and relate to the protected areas in both countries, while the remaining nine chapters relate to particular countries or specific localities in them. The introductory chapter gives an overview of the protected areas in Croatia and Slovenia and the differences in the ways they are protected, while the concluding chapter, with a synthesis of the findings from the previous chapters, offers possible solutions for the future, based on the exchange of experiences and best practices from both countries.

Among the nine country-specific chapters, one paper is focused on the issue of transport accessibility as a factor of tourism flow in protected areas in Croatian national and nature parks, and one paper is focused primarily on spatial planning issues and tourism development in protected nature areas in Slovenia using the protected area of the Škocjan Caves as a case study. Of the remaining seven papers, one relates to four protected areas in the Slovenian coastal area (Landscape Parks Sečovlje Saltpans, Strunjan and Debeli rtič and the Škocjanski zatok Nature Reserve) and six to particular protected areas: Krka, Mljet and Plitvice Lakes National park in Croatia and protected areas of the Kraški Rob, Sviščaki and Škocjanski zatok in Slovenia. Besides describing the situation in particular area, each of the papers focuses on specific aspects of nature protection: tourism development, climate change, consequences of protection on demographic trends and economic development, second homes and issues of protected area management.

Therefore, this scientific book is a good example of a comprehensive analysis of how protected areas are managed in different countries and the analysis of various aspects of the impact of tourism on nature protection and vice versa. Of particular value to this book is a fact that it includes works from two neighboring countries, which, with many similarities, have many differences in the nature protection issues. Apart from the exchange of experience, this is also important in order to propose effective management tools in protected areas in both countries, especially in neighbouring areas near the state border between Croatia and Slovenia. This is especially important today, when protected areas are exposed to increasing tourism pressure with the dangerous consequences for the protection 
of ecosystems in both countries and the entire European Union to which Croatia and Slovenia belong.

Having in mind afore mentioned issues, this publication could arouse great interest from the scientific public, not only geographical but also by other scientific population and general public. This primarily refers to all stake holders interested in nature protection and individuals engaged in various types of tourist and other activities in protected areas. This is especially important nowadays, when environmental awareness is growing, and the concept of sustainable development that takes care of the environment is becoming a mainstream in tourism planning in the world.

Although the chapters of the book are made in the form of individual works and have been produced by different authors, the book has the form of a coherent material. Namely, each of the papers looks at the issues of environmental protection and management of protected areas in a different way, covering all key aspects, from climate change to the carrying capacity of protected areas for tourism. Therefore, this scientific book represents a useful tool for the scientific and other population interested in environmental protection and tourism development in protected areas not only in Croatia and Slovenia, but also in other countries.

Zoran Klarić, PhD

Scientific Advisor, Institute for Tourism

Zagreb, Croatia 

The monograph offers an in-depth insight into the issues of tourism in protected areas in both countries. Although various authors from different research fields participated in the preparation of the monograph, it nevertheless works as a whole, as the contents of individual chapters complement each other and successfully discuss the issues from several angles. The specific quality of the monograph is also reflected in transcending national boundaries, and such a transnational perspective also helps to place the presented cases in the broader context of tourism development in protected areas.

Dejan Cigale, PhD, Assistant Professor University of Ljubljana, Faculty of Arts, Department of Geography Ljubljana, Slovenia

This scientific book is a good example of a comprehensive analysis of how protected areas are managed in different countries and the analysis of various aspects of the impact of tourism on nature protection and vice versa. Of particular value to this book is a fact that it includes works from two neighbouring countries, which, with many similarities, have many differences in the nature protection issues. Apart from the exchange of experience, this is also important in order to propose effective management tools in protected areas in both countries, especially in neighbouring areas near the state border between Croatia and Slovenia. This is especially important today, when protected areas are exposed to increasing tourism pressure with the dangerous consequences for the protection of ecosystems in both countries and the entire European Union to which Croatia and Slovenia belong.

Zoran Klarić, PhD, Scientific Advisor Institute for Tourism

Zagreb, Croatia

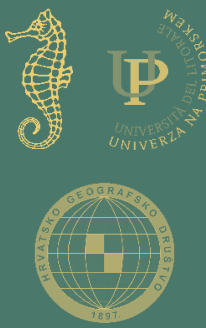

